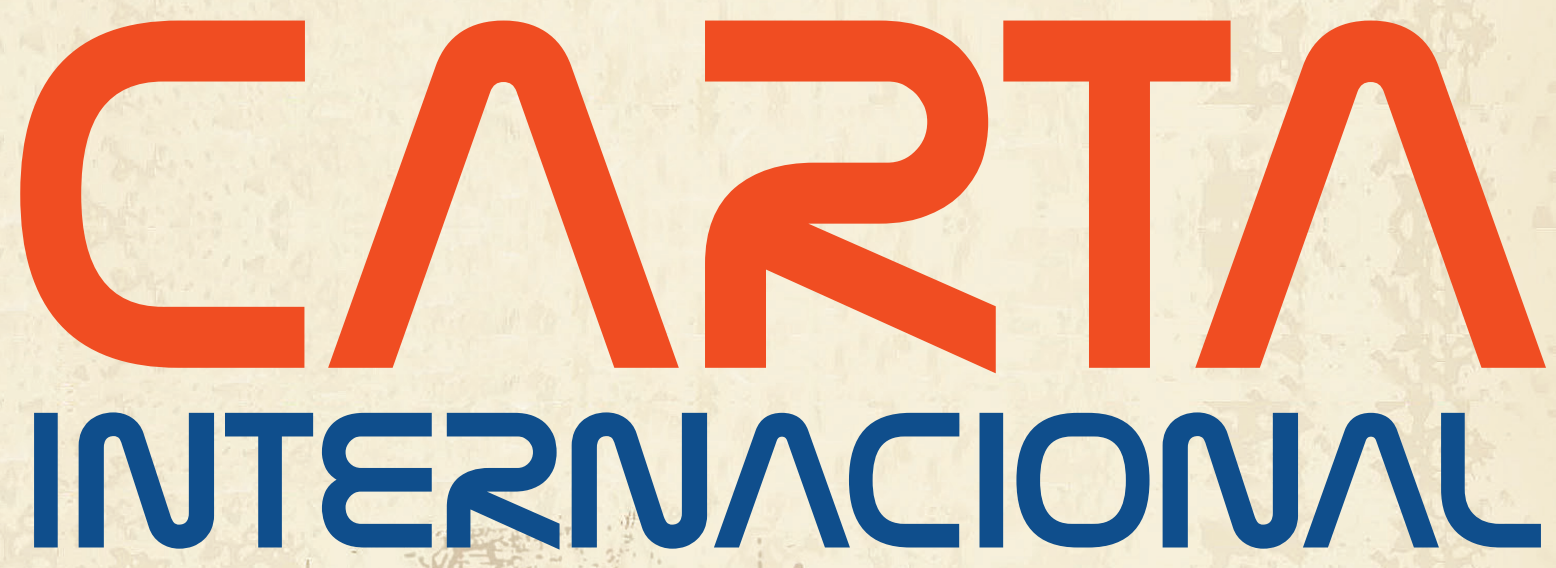

PUBLICAÇÃO DA ASSOCIAÇÃO BRASILEIRA DE RELAÇÕES INTERNACIONAIS

ISSN 2526-9038 - V. 12, No 2, maio/agosto de 2017 • DOI: 10.12530/ci.v12n2.2017 


\section{Expediente}

Carta Internacional é uma revista eletrônica de publicação quadrimestral dedicada ao debate sobre as questões mais relevantes das relações internacionais sob a perspectiva brasileira. As opiniões expressas nos artigos assinados são de responsabilidade exclusiva de seus autores e não expressam as opiniões da Associação Brasileira de Relações Internacionais (ABRI).

A Revista Carta Internacional foi fundada em 1993 por José Augusto Guilhon Albuquerque, no Núcleo de Pesquisas em Relações Internacionais da Universidade de São Paulo (NUPRI/USP). Em 2011 tornou-se a publicação científica da Associação Brasileira de Relações Internacionais (ABRI).

Carta Internacional é publicada pela Associação Brasileira de Relações Internacionais (ABRI). A revista está disponível para download gratuito, em formato PDF, no endereço:

< http://www.cartainternacional.abri.org.br > .

\section{Editora Chefe:}

Matilde de Souza

\section{Editora Associada:}

Letícia Carvalho

\section{Editores Assistentes}

Rebeca Caeiro e Mateus Silva

\section{Diagramação:}

Samuel Tabosa

\section{Revisão:}

Luís Fernando dos Reis Pereira

\section{Secretaria da Carta Internacional:}

Airá Eventos Técnico-Científicos

\section{Conselho Científico:}

Amado Luiz Cervo, André Singer, Andrew Hurrell, Anthony Pereira, Antônio Carlos Lessa, Arlene Tickner, Carlos Eduardo Lins da Silva, David Mares, Eduardo Viola, Elizabeth Balbachevsky, Félix Peña, Fernando Augusto Albuquerque Mourão, Gary Hufbauer, Gilson Schwartz, Gladys Lechini, Gustavo Vega-Cánovas,
Henrique Altemani de Oliveira, José Augusto Guilhon Albuquerque, Luis Olavo Baptista, Margarita Silvia Olivera, Maria Cristina Cacciamali, Maria Regina Soares de Lima, Paulo Fagundes Visentini, Paulo Lavigne Esteves, Peter Demant, Rafael Antônio Duarte Villa, Sean Burges e Tullo Vigevani.

\section{Redes Sociais:}

Facebook: Carta Internacional

Twitter: @CartaAbri

LinkedIn: Revista Carta Internacional

Academia.edu: Revista Carta Internacional

\section{Associação Brasileira de Relações Internacionais (ABRI)}

Presidente:

Eugênio Pacelli Lazzarotti Diniz Costa (PUC Minas)

\section{Secretária Executiva:}

Layla Ibrahim Abdallah Dawood (UERJ)

Secretário Executivo Adjunto:

Haroldo Ramanzini Junior (UFU)

\section{Tesoureira:}

Graciela De Conti Pagliari (UFSC)

\section{Diretores:}

Cristina Soreanu Pecequilo (UNIFESP)

Ana Flávia Barros-Platiau (UnB)

Carolina Moulin (PUC-Rio)

Marcos Ferreira da Costa Lima (UFPE)

Conselho Fiscal:

Henrique Altemani de Oliveira (UEPB)

Túlio Sérgio Henriques Ferreira (UFPB)

\section{Correspondência:}

Avenida Dom José Gaspar, 500 - Prédio 04 - Sala 01 Coração Eucarístico Belo Horizonte, MG - CEP: 30535-901 Tel.: + 55 (31) 3241-5123

email: cartainternacional@abri.org.br

(C) 2017 Associação Brasileira de Relações Internacionais (ABRI). Todos os direitos reservados. 


\section{Sumário}

A evolução dos métodos de trabalho e a emergência do consenso no Conselho de Segurança da ONU: a tomada de decisão por comitês | The evolution of work methods and the emergency of consensus in the un security council: decision-making by committees | 5

Mariana Baccarini

Aspectos normativos, securitários e geopolíticos da grande estratégia da Rússia (2000-2016) e o lugar das Nações Unidas | Normative, security and geopolitical aspects of Russian grand strategy (2000-2016) and the UN's place | 30 Bruno Gomes Guimarães

Hegemonia compartilhada e organizações internacionais: a proposta trilateralista dos anos de $\mathbf{1 9 7 0}$ | Shared hegemony and international organizations: the trilateralist proposal of the 1970's | 55

Rejane Hoeveler

A Diretiva Europeia sobre Aquisições em Segurança e Defesa:

Impactos na Logística de Defesa | The European Directive on Acquisitions in Security and Defence: Impacts on Military Logistics | 76

Bruna Rohr Reisdoerfer

Luiz Rogério Franco Goldoni

Barack Obama e o Oriente Médio: Um Panorama Crítico (2009/2017) | Barack Obama and the Middle East: A Critical Overview (2009/2017) | 101 Cristina Soreanu Pecequilo Clarissa Nascimento Forner

O sentimento anti-Japão na China: origens, estímulos e consequências | The anti-Japan sentiment in China: origins, stimulus and consequences | 126 Hércules Paulino de Souza 
Mudança Institucional em Regimes de Direitos Humanos: o Sistema Interamericano e os Estados "em cima do muro" | Institutional change in Human Rights Regimes: the Inter-American System And States 'on the fence' | 150 Isabela Gerbelli Garbin Ramanzini

Economia Política Internacional da Saúde, autonomia estratégica e segurança nacional | Health International Political Economy, strategic autonomy and national security | 174 Raphael Padula

Política externa independente e a institucionalização das atividades espaciais no Brasil: histórias cruzadas | Independent Foreign Policy and the institutionalization of space activities in Brazil: intersecting stories | 197 Renata Corrêa Ribeiro

A geopolítica das terras raras | The Geopolitics of rare earths | 219 Filipe Reis Melo 


\title{
A evolução dos métodos de trabalho e a emergência do consenso no Conselho de Segurança da ONU: a tomada de decisão por comitês
}

\author{
The evolution of work methods and the \\ emergency of consensus in the un security council: \\ decision-making by committees
}

DOI: $10.21530 /$ ci.v12n2.2017.628

Mariana Baccarini ${ }^{1}$

\section{Resumo}

A dificuldade de se reformar formalmente o Conselho de Segurança das Nações Unidas não impediu que ocorresse no órgão uma reforma informal de seu processo decisório, envolvendo seus métodos de trabalho. A busca por maior participação, accountability e transparência nos trabalhos da principal organização internacional, responsável pela paz e segurança internacionais, é objetivo não somente de Estados não membros do órgão como também de seus membros não permanentes, que questionam incessantemente a dominância dos membros permanentes no processo de tomada de decisão. O objetivo deste artigo é discutir como, com o fim da Guerra Fria, o padrão de votação do Conselho de Segurança sofreu alterações substantivas, de um processo conflituoso para um outro, em alguma medida, cooperativo, resultante da evolução dos métodos de trabalho e, em especial, da proliferação dos comitês de decisão. Com isso, vemos emergir um padrão consensual de decisão em que, na grande maioria das votações, os quinze membros votam afirmativamente para a aprovação das resoluções.

Palavras-chave: Conselho de Segurança das Nações Unidas; consenso decisório; comitês de decisão

\footnotetext{
Abstract

The difficulty of formally reform the United Nations Security Council did not prevent an informal reform of its decision-making process, involving its working methods. The pursuit of greater participation, accountability and transparency in the work of the main international

1 Departamento de Relações Internacionais do Centro de Ciências Sociais Aplicadas da Universidade Federal da Paraíba, em João Pessoa/PB, Brasil. E-mail: marianabaccarini@gmail.com

Artigo submetido em 09/02/2017 e aprovado em 25/08/2017.
} 
institution responsible for international peace and security is the goal of not only the nonmember states of the body but also its non-permanent members, who incessantly question the dominance of the permanent members in the decision-making process. The objective of this article is to demonstrate how, with the end of the Cold War, the voting pattern of the Security Council has undergone substantive changes, from a conflictive process to a cooperative one, as a result of the evolution of working methods and, particularly, the proliferation of decision-making committees. Thereby, we see a consensual pattern of decision emerge, in which, in the great majority of votes, the fifteen members vote affirmatively for the approval of resolutions.

Keywords: United Nations Security Council; Decision-making consensus; decision-making committees

\section{Introdução}

Durante quase setenta anos de existência da Organização das Nações Unidas (ONU), somente uma reforma foi feita, referente ao número de assentos do Conselho de Segurança (CSNU), aumentando os membros não permanentes do órgão de 6 para 10, mudança formalizada em 1965. As críticas de que a atual composição do CSNU já "não reflete as realidades geopolíticas, econômicas e demográficas do sistema internacional presente” (HOSLI et al., 2011. p. 5, tradução livre) se encontram amplamente difundidas. No entanto, apesar das vantagens em se tornar um membro não permanente do CSNU, como prestígio, oportunidade de voz, visibilidade, obtenção de projetos do Banco Mundial e FMI etc. (DREHER; STURM; VREELAND, 2009a; DREHER; STURM; VREELAND, 2009b), sua influência na tomada de decisão é muito menor do que a dos membros permanentes, ou mesmo ínfima, como aponta O’Neill (1996).

Apesar da reforma estar na pauta da ONU há anos, sendo frequentemente lembrada por Estados interessados, as negociações na organização se encontram travadas, em especial no Open-ended Working Group on the Question of Equitable Representation on and Increase in the Membership of the Security Council and Other Matters Related to the Security Council, criado pela Assembleia Geral da ONU (AGNU) em 1993. O grupo, conhecido como never-ending working group (LUCK, 2006), não consegue chegar a um rascunho de proposta a ser votado na AGNU, mesmo com os esforços de seus presidentes, o que não permite aos membros permanentes (P5) sequer se posicionarem quanto à possibilidade de um veto formal. 
Se reformas na Carta são difíceis de serem conseguidas, várias modificações dos métodos de trabalho do CSNU ocorreram, aumentando a abertura e a accountability do órgão, assim como possibilitando diferentes inputs na tomada de decisão (WEISS, 2003).

O aumento da quantidade de encontros informais no CSNU no pós-Guerra Fria aponta, inicialmente, para maior importância dos membros não permanentes (também conhecidos como E10, por serem dez membros eleitos) e mesmo de outros Estados não pertencentes ao Conselho. Observou-se uma proliferação dos grupos e das negociações informais de Estados, o que possibilitou uma saída dos constrangimentos institucionais e estruturais do CSNU, garantindo voz a outros Estados, apoiadores das missões de paz e stakeholders de conflitos (PRANTL, 2006). Dessa forma, consultas entre membros do CSNU e não membros podem ser consideradas um desenvolvimento na estrutura informal (HURD, 1997). A evolução de práticas informais prolongaria a estabilidade da estrutura organizacional e do órgão na ocorrência de novas circunstâncias externas. Além disso, tais inclusões informais de Estados e grupos nas deliberações do CSNU ajudaram o órgão a manter sua legitimidade, apesar das enormes mudanças no ambiente político e da dificuldade na realização de mudanças formais.

O objetivo deste artigo é analisar o desenvolvimento dos métodos de trabalho do CSNU. Nossa hipótese é que, em momento imediatamente posterior ao fim da Guerra Fria, o Conselho de Segurança deixou de se orientar pelas regras formais (maioria qualificada e poder de veto) para um funcionamento por comitê, sustentado pela alteração dos métodos de trabalho do órgão, tendo por resultado a emergência de um padrão consensual de tomada de decisão formal. Entretanto, o surgimento desse sistema de comitês não teria alterado substancialmente os inputs da tomada de decisão, que segue dominada pelos membros permanentes.

Para tanto, o artigo é estruturalmente constituído por essa introdução, seguida da segunda sessão, em que se expõe o referencial teórico que embasará a análise, em especial o conceito de "comitê" elaborado por Sartori (1994). Posteriormente, na terceira sessão, apresenta-se a evolução dos métodos de trabalho do órgão e a emergência do consenso decisório e dos comitês de decisão no CSNU no pósGuerra Fria. As conclusões são apresentadas ao final. 


\section{O processo de tomada de decisões em organizações internacionais: os Comitês}

Em 1957, David Easton já afirmava que um sistema político está sujeito a diferentes demandas e inputs, convertidos em outputs pelos processos desse sistema. Tais outputs representam as decisões autoritativas resultantes do processo decisório e implicam consequências aos mesmos processos e ao ambiente em que tais decisões estejam inseridas. O funcionamento desse sistema, entretanto, depende da manutenção dos inputs, sendo necessário:

Identificar os inputs e as forças que os alteram e mudam, traçar os processos através dos quais são transformados em outputs, descrever as condições gerais em que estes processos podem ser mantidos, e estabelecer a relação entre outputs e inputs seguintes do sistema. (EASTON, 1957, p. 386, tradução livre)²

Existiriam dois tipos de inputs: as demandas e o apoio. Os sistemas políticos são resultados da demanda latente de grupos e pessoas que não conseguem se satisfazer totalmente nesse ambiente culturalmente delimitado (demanda externa). Por sua vez, os próprios sistemas políticos ocasionam uma demanda interna, decorrente de alterações nas relações políticas entre os membros, podendo, inclusive, estar ligadas à representação no sistema. Entretanto, nem toda demanda é transformada em questão a ser tratada, pois depende da estrutura de poder de tal sociedade, habilidade do apoiador, canal de comunicação etc. (EASTON, 1957).

Já o apoio se refere às ações e orientações que promovem e oferecem resistência a um sistema político e às demandas que chegam. $\mathrm{O}$ apoio é o conjunto de atitudes/predisposições de agir ou de efetivas ações por parte de um ator que promovam os interesses, objetivos e ações dos outros atores. Uma das principais formas de garantir o fluxo de apoio é o provimento de outputs (decisão política ou a própria política - policy). Tais decisões têm por objetivo satisfazer as demandas dos membros. Entretanto, nem todas as demandas podem ser atendidas ao mesmo tempo, sendo esperado que ao menos as principais demandas dos membros mais influentes o sejam. Por sua vez, a falta de equilíbrio entre quais demandas serão atendidas e quais não serão pode gerar pressões por mudanças no sistema, apesar

2 "Identify the inputs and the forces that change and shape them, to trace the processes through which they are transformed into outputs, to describe the general conditions under which such processes can be maintained, and to stablish the relationship between outputs and succeeding inputs of the system" (EASTON, 1957, p. 386). 
dos processos de socialização, politização e aprendizado tenderem a aliviar tais pressões (EASTON, 1957).

Para Rittberger, Zangl e Staisch (2006), entendendo-se organizações internacionais (OIs) enquanto sistemas políticos, os responsáveis pelos inputs (demanda e apoio) teriam influência variada em transformar sua demanda em outputs. A influência dos governos dos Estados membros depende da contribuição financeira destes à organização; do fornecimento de informação; do controle de recursos específicos de uma determinada área temática (issue-area power) em relação ao controle de recursos que transcendem questões (overall power); e do impacto da OI em reduzir diferenças de influência entre esses Estados ${ }^{3}$ (RITTBERGER; ZANGL; STAISCH, 2006).

Por sua vez, o processo de conversão, ou processo decisório, pode ter diferentes características, dependendo da organização e do tema a ser tratado, podendo predominar as negociações intergovernamentais, o voto por maioria, a escolha racional, os procedimentos operacionais padrão ou a política burocrática ${ }^{4}$ (RITTBERGER; ZANGL; STAISCH, 2006).

Por fim, os outputs poderiam ser caracterizados como programas políticos, atividades operacionais ou atividades de informação. Os programas políticos constituem um conjunto de normas e regras para direcionar o comportamento dos atores, que podem ter efeitos regulatórios, distributivos ou redistributivos e com caráter vinculativo (binding nature). As atividades operacionais se caracterizam pela especificação e concretização das normas e regras dos programas políticos, implementação, monitoramento, adjudicação e imposição de sanções em casos de não aquiescência. Por fim, as atividades de informação impactam diretamente os outros outputs, pois resultam em coleta, publicação, geração de informação

3 Outros tipos de responsáveis por inputs e suas possíveis influências: a) administração da própria organização: a influência se refere à vantagem de informação privilegiada e da sua capacidade de definição da agenda; b) assembleias parlamentares: influência depende da sua legitimidade e da redução do déficit democrático; c) grupos de interesse, em especial das ONGs: influência depende da sua capacidade de prover informação e especialidade; d) comunidade de especialistas: influência depende da existência de um consenso ao conselho a ser dado para a tomada de decisão na organização, ou seja, se formam uma comunidade epistêmica.

4 Modelos de Tomada de Decisão: a) negociações intergovernamentais: entre atores mais poderosos representando interesses divergentes. A decisão requer compromisso e o acordo se dá sobre o mínimo denominador comum. A equipe administrativa se apresenta como mediadores ou brokers; b) voto por maioria: formação de maioria por coalizão. A decisão tende a ser influenciada por grupos de interesses mais poderosos, mas pode ser moldada pela equipe administrativa (draft decisions); c) escolha racional: cálculo de custo/benefício e escolha pela opção que melhor serve aos interesses da organização; d) procedimentos operacionais padrão: decisões como produto de procedimentos de rotina. Legitimação ex-post; e) política burocrática: diferentes ramos dentro da administração podem favores diferentes decisões (RITTBERGER; ZANGL; STAISCH, 2006). 
independente (comunidades epistêmicas) e fórum para troca de informação (RITTBERGER; ZANGL; STAISCH, 2006).

De acordo com Sartori (1994), as decisões coletivizadas (ou de caráter vinculativo) se aplicam não somente àqueles que tomam as decisões, mas a toda coletividade. São soberanas, inescapáveis e sancionáveis e resultam em: custos internos e procedimentais para quem toma as decisões; riscos externos, de opressão e/ou incompetência, relacionados ao prejuízo de quem as recebe, por não participarem da decisão (SARTORI, 1994).

Enquanto os custos aumentam com a ampliação do número dos tomadores de decisão, os riscos diminuem, e vice-versa. Dessa forma, custos e riscos são inversamente relacionados. Assim, a regra da unanimidade implica em custos altos, enquanto a regra da maioria, seja ela qualificada, simples ou relativa, reduz os custos decisórios. A escolha da regra é função da busca por "um equilíbrio entre a conveniência (redução dos custos decisórios) e a segurança (redução dos riscos externos); e esse equilíbrio é alcançado em definições majoritárias diferentes em função da importância maior ou menor das coisas a serem decididas" (SARTORI, 1994, p. 296).

O contexto decisório pode ser descontínuo, em que as questões são distintas, separadas, ou contínuo, em que os grupos são encarregados de um fluxo de decisões tratadas de maneira interligada, constantemente envolvidas em trocas recíprocas. Tais grupos são identificados como comitês. Os atores apresentam "intensidade desigual de preferências individuais" e as regras da maioria "tornam iguais intensidades diferentes”, ocasionando, na maioria das vezes, em jogos de soma zero ${ }^{5}$ (SARTORI, 1994).

Nas relações internacionais, um dos primeiros esforços em analisar o impacto no processo de tomada de decisão por consenso se dá em 1981, quando Buzan (1981) escreve sobre a tomada de decisão da Conferência das Nações Unidas sobre Direito do Mar. Para o autor, a tendência era de emergência de um novo padrão decisório, com regras formalizando a tomada de decisão por consenso, o que se opunha aos mecanismos informais e que vinham se desenvolvendo em organizações e órgãos internacionais.

Idealmente, apesar das negociações preverem a possibilidade de votação, a expectativa era de que essas não fossem utilizadas, o que reduziria o peso na

5 Em casos de fluxo contínuo de decisões e maiorias concretas cíclicas, ou coalizões instáveis, apesar do resultado da decisão também ser de soma zero, o processo pode gerar compensações de soma positiva entre essas maiorias cambiantes e de pouca coesão (SARTORI, 1994). 
tomada de decisão de uma maioria sem correspondente poder internacional, resultante da expansão dos membros das organizações internacionais. Para tanto, mecanismos procedimentais reordenariam o processo decisório, reconectando poder, em seu sentido estrito, material, e poder decisório (BUZAN, 1981).

A “intensidade desigual de preferências individuais" pode ser considerada uma vantagem, tendo em vista que o acordo em um grupo ocorre justamente pois os não intensos cedem aos intensos (SARTORI, 1994). A disputa entre uma minoria forte e interessada e uma maioria fraca e motivada por questões mais locais e sem poder marítimo, proporcionando um balanceamento político, favoreceu a alteração decisória na Conferência das Nações Unidas sobre Direito do Mar. O direito coletivo e a responsabilidade de elaborar o rascunho foram delegados aos presidentes dos três principais comitês. As negociações e seus avanços resultaram em reformulações desse rascunho, sempre tratado como informal e sem implicar compromissos obrigatórios (BUZAN, 1981).

Segundo Buzan (1981), tal concentração nas mãos dos presidentes 1) possibilitou a existência de um "resultado nos vários estágios da negociação", reduzindo a incerteza; 2) proveu incentivos para os delegados iniciarem compromissos; 3) serviu como prospecto de progresso em direção a um acordo; 4) e como mecanismo para que grupos privados trabalhassem com status de grupo de trabalho. Uma segunda evolução dos procedimentos foi a criação dos grupos de negociação para lidar com questões e problemas centrais e específicos, o que acabou reduzindo o poder dos presidentes dos comitês (BUZAN, 1981).

Para Sartori (1994), um comitê é composto por grupo pequeno, de interação face a face, durável e institucionalizado (independente da renovação, em que membros agem como se fossem permanentes, contra a expectativa), em um contexto decisório contínuo, com fluxo de decisões (SARTORI, 1994).

Os comitês atuam em condições de pouca visibilidade, propondo, examinando e discutindo questões políticas. Seu funcionamento não se baseia na regra da maioria, e as decisões não são postas em votação. O voto se torna pro forma e as decisões são unânimes, não porque funcionam pela unanimidade (em que todos detêm o poder de veto), mas porque cada componente do grupo espera que aquilo que for concedido no presente lhe será devolvido ou retribuído em negociações futuras. Tal código operacional funciona a partir da lógica conciliatória do "dou para receber de volta”, da ajuda mútua, negociação e solução de contemporização, uma "compensação recíproca retardada". Em casos extremos de conflito, tais comitês podem decidir pelo princípio da maioria, mas quando essa se torna a 
regra, implementando o jogo de soma zero, sem possibilidade de ordenamento de preferências, tem-se delineada a linha divisória entre um comitê e um não comitê (SARTORI, 1994).

Tais comitês se embrenham em um "subsistema de comitês" que possibilita, para além dos pagamentos internos, os pagamentos laterais, externos, por via de outros comitês, em um mecanismo de coordenação. Esses pagamentos laterais não necessariamente são negociados de forma explícita, podendo ocorrer por meio de negociações de votos e por reações antecipadas a possíveis decisões de um determinado comitê, favorecendo o ajustamento e a coordenação (SARTORI, 1994).

Sartori (1994) resume seu argumento, afirmando que

Os comitês evitam a regra da maioria, procuram acordos unânimes por meio de pagamentos retardados internos e se ajustam ao mundo exterior ou incorporam suas demandas através de pagamentos laterais. As assembleias institucionalizadas funcionam, ao invés, de acordo com a regra da maioria, mas podem ou não apresentar, com o passar do tempo, um resultado de soma zero, dependendo da fixidez de suas maiorias. As coletividades votantes e dispersas são caracterizadas - independente de seu tamanho - pelo fato de um universo disperso ser incapaz de interagir ou de admitir trocas de votos (...) não podem negociar, nem fazer acordos. (SARTORI, 1994, p. 316)

Aparentemente, segue-se que as decisões por comitê seriam preferíveis. Entretanto, como o próprio autor salienta, os resultados de jogos de soma positiva levam a mudanças incrementais, enquanto as mudanças decisivas se dariam com decisões de soma zero (SARTORI, 1994).

Em modelos de teoria dos jogos não cooperativos, em que os atores são autointeressados em situações nas quais precisam cooperar para alcançar benefícios mútuos, a cooperação depende de instituições em nível doméstico como comitês ou partidos. Nas relações internacionais, "Estados e outras entidades desenham formas institucionais (organizações, procedimentos, arranjos cooperativos informais, tratados) que os auxiliam na realização de seus objetivos" (MARTIN; SIMMONS, 1998, p. 740).

Nos modelos informacionais, os comitês legislativos provêm informação sobre as políticas propostas, evitando resultados ineficientes, e essa preocupação com a informação explicaria tanto o padrão de seleção de legisladores ao comitê quanto as próprias regras de tomada de decisão. Já nos modelos distributivos, 
o foco seria na heterogeneidade das preferências, em que comitês favoreceriam o equacionamento das diferentes intensidades. A expectativa é que os membros de um determinado comitê seriam aqueles com maior intensidade de preferência sobre a questão tratada, tendo esse comitê o poder de determinação da agenda temática e auxílio na realização de issue linkages (MARTIN; SIMMONS, 1998).

\section{A emergência do Consenso Decisório e dos Comitês de Decisão no Conselho de Segurança das Nações Unidas}

\section{O Consenso Decisório no CSNU no pós-Guerra Fria}

O CSNU é o principal órgão responsável pela tomada de decisão acerca de questões referentes à paz e segurança internacionais. De caráter vinculatório, as decisões tomadas pelo órgão devem ser implementadas e apoiadas por todos os membros da organização, independente de posterior aprovação. Dessa forma, a participação em seu processo decisório é tema sensível e constantemente debatido, tendo em vista os interesses dos Estados em garantir que seus inputs, em especial suas demandas, sejam ouvidos e levados em consideração pelo sistema político.

Nos dizeres de Sartori (1994), entendendo o CSNU enquanto uma arena de decisões coletivizadas que se estendem a todos os Estados por lidar com questões de paz e segurança internacionais em contexto contínuo de tomada de decisões obrigatórias, pode-se, a priori, considerá-lo um comitê, em um jogo de soma positiva pelo seu próprio propósito.

Entretanto, a própria regra de tomada de decisão do CSNU implica conjunção de funcionamento por assembleia institucionalizada, com tomada de decisão por maioria qualificada ( 9 dos 15 votos), e de funcionamento por comitê, com unanimidade (entre os membros permanentes, devido ao poder de veto). Ou seja, uma mistura entre um jogo de soma zero (em relação à maioria), e um jogo de soma positiva (em relação à unanimidade), nos dizeres de Sartori (1994) .

Durante a Guerra Fria, pode-se observar o funcionamento da regra da maioria qualificada, quebrada constantemente pelos vetos (Gráfico 1), em especial da União Soviética e dos Estados Unidos. A ausência de negociação e coordenação entre os membros permanentes impossibilitava o funcionamento do principal comitê, que posteriormente seria reconhecido como P5. 
Gráfico 1: Quantidade de resoluções vetadas pelos membros permanentes do CSNU de 1946-2013

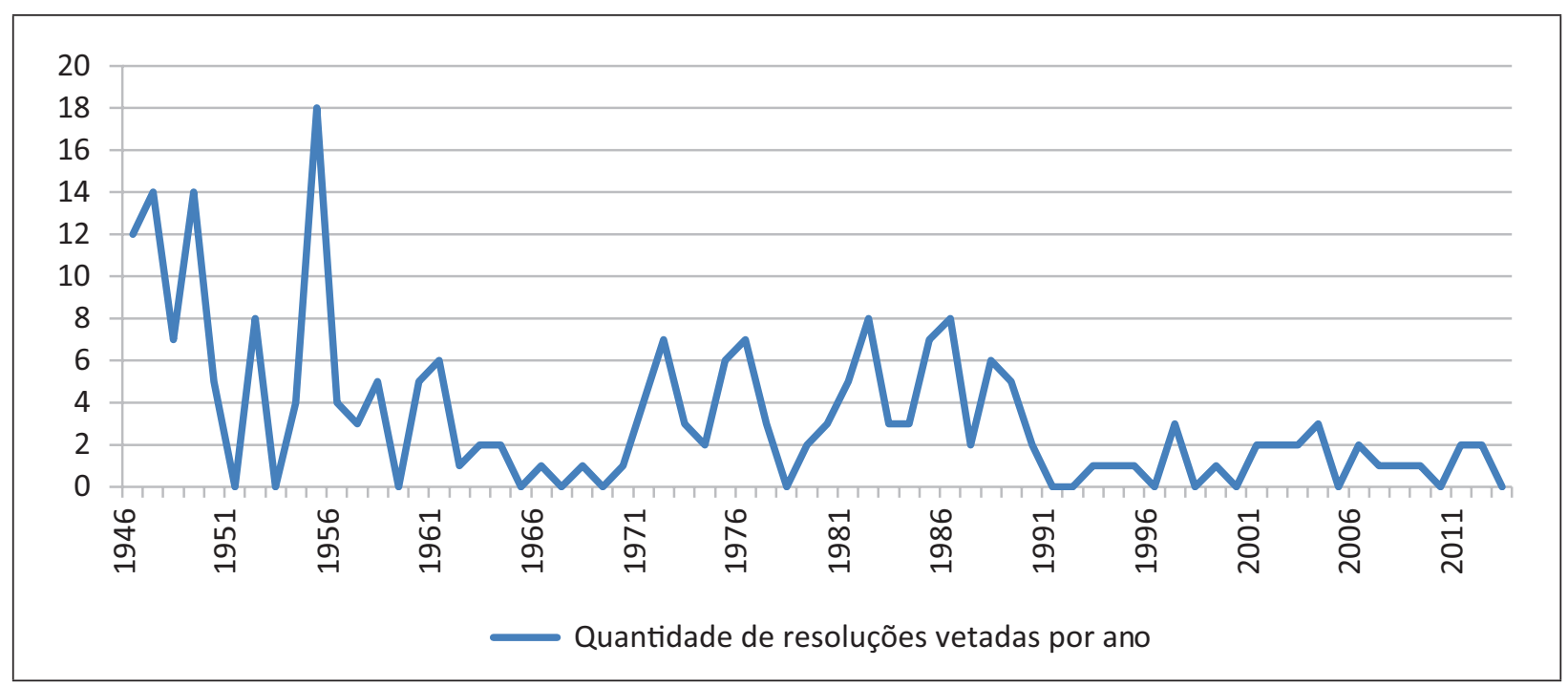

Fonte: elaboração própria, com base em ONU, 2013.

Entretanto, desde o fim da Guerra Fria, o CSNU vem se orientando por um padrão de votação consensual. Como aponta o Gráfico 2, cerca de $90 \%$ das decisões totais do órgão se dão com votos afirmativos dos 15 membros. Essa porcentagem poderia aumentar consideravelmente se fossem incluídas as votações com abstenções ou em que houve ausência de membros na votação.

Gráfico 2: Quantidade de votações totais e consensuais no Conselho de Segurança de 1946-2013

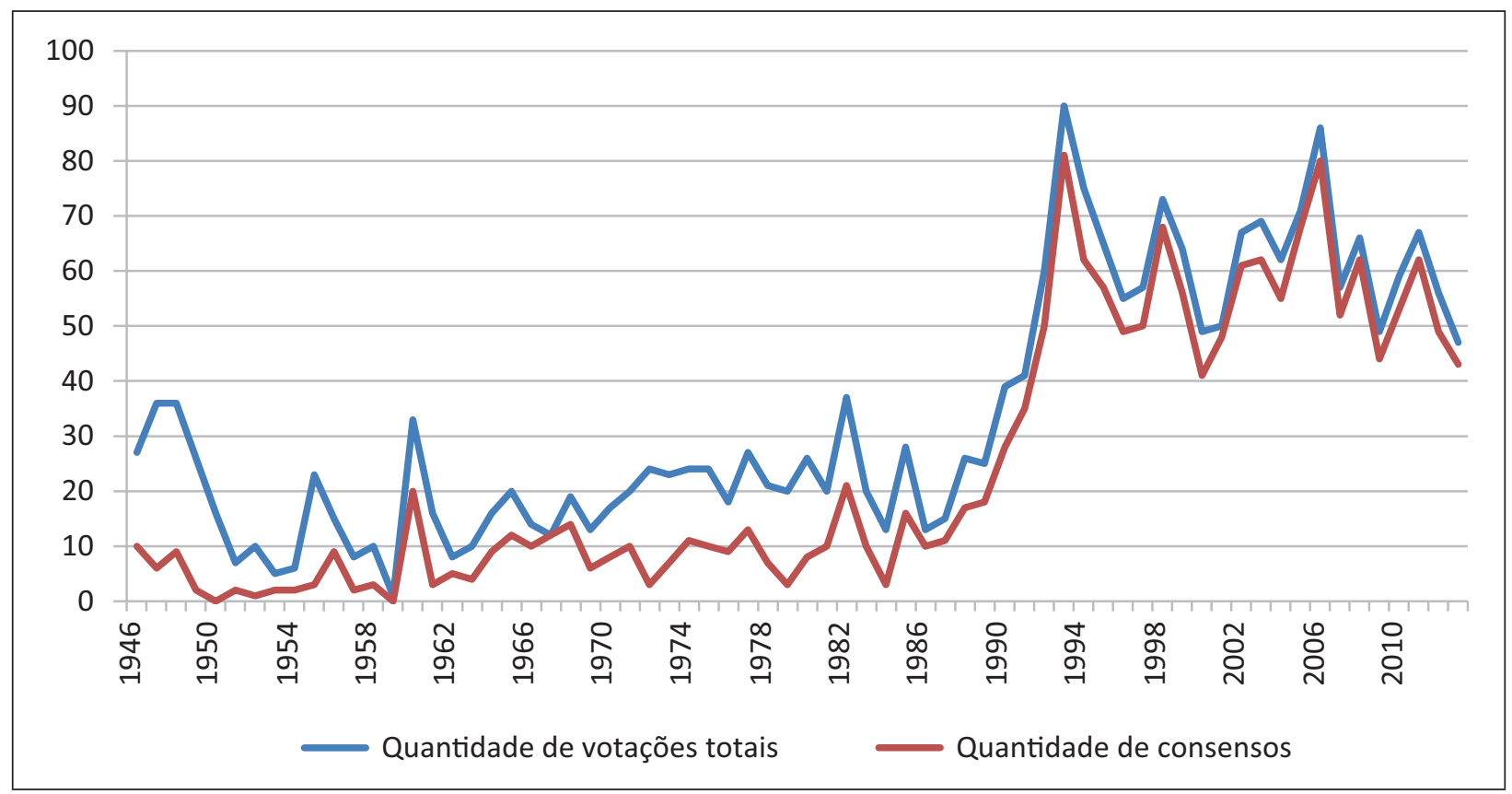

Fonte: elaboração própria, com base em ONU, 2013. 
O que poderia ter motivado a alteração no padrão de tomada de decisão do CSNU 6 ? Quais foram os mecanismos e procedimentos criados que, aparentemente, favoreceram a alteração de uma decisão mais conflitiva para um processo supostamente mais cooperativo, culminando com a votação consensual? Se o poder da tomada de decisão se encontra predominantemente nas mãos do P5, como aponta O’Neill (1996), por que os membros não permanentes também seguem o mesmo padrão de votação?

\section{A evolução dos métodos no CSNU?}

Em 1946, em decorrência do não acordo quanto à formalização dos métodos de trabalho do CSNU, foram aprovadas as "Regras de Procedimento Provisórias" do órgão, várias vezes revisadas, mas que continuam sendo consideradas provisórias. Enquanto formalmente as regras de procedimento não são definidas, os procedimentos e práticas informais definem a operação do órgão. Em caso de dúvidas quanto a determinadas práticas, por exemplo, o embaixador mais antigo do P5 provê uma interpretação considerada oficial.

Transparência, participação, accountability e eficiência continuam no centro das discussões. A reforma dos métodos de trabalho do CSNU é considerada um tema sensível e, em 1993, foi criado o Open-Ended Working Group on the Question of Equitable Representation on and Increase in Membership of the Security Council and Other Matters Related to the Security Council (AGNU, 2007). O objetivo, explícito em seu próprio nome, era discutir duas questões: 1) a composição do órgão e 2) os métodos de trabalho do processo de tomada de decisão.

6 Alguns autores apontam a possibilidade da existência de suborno no Conselho de Segurança o que, em parte, poderia explicar a emergência do consenso decisório. Entretanto, diferentes metodologias, mesmo partindose dos mesmos dados, apresentaram conclusões contraditórias quanto à questão. Para mais informações ver: Kuziemko; Werker, 2006; Diniz; Baccarini, 2014.

7 Grande parte das informações dessa seção referentes aos métodos de trabalho do órgão foi baseada nos relatórios sobre os métodos de trabalho do CSNU elaborados pelo Security Council Report, organização não lucrativa, independente, financiada por diversos governos e fundações, e que provê informações e análise sobre os trabalhos do CSNU. Os principais relatórios utilizados foram os Special Research Report referentes ao tema, publicados em 2007, 2010 e 2014, e o Updater Report de 2008 (referência completa ao final do artigo). Para mais informações, vide site < http://www.securitycouncilreport.org/index.php > . Além desses relatórios, uma série de documentos da ONU foram analisados e citados ao longo da seção. 


\section{Quadro 1: Os grupos de questões do Open-ended Working Group on the Question of Equitable Representation on and Increase in the Membership of the Security Council and Other Matters Related to the Security Council}

\begin{tabular}{|l|l|}
\hline \multicolumn{1}{|c|}{$\begin{array}{c}\text { Grupo 1: Aumento da quantidade de membros } \\
\text { e questões relacionadas }\end{array}$} & \multicolumn{1}{c|}{$\begin{array}{c}\text { Grupo 2: Métodos de trabalho } \\
\text { e transparência }\end{array}$} \\
\hline $\begin{array}{l}\text { Expansão do CSNU: determinação de quais categorias } \\
\text { serão expandidas (não permanentes, permanentes, } \\
\text { questão sobre prerrogativas e poderes, tamanho do } \\
\text { alargamento). }\end{array}$ & $\begin{array}{l}\text { Melhoramento da transparência e métodos de } \\
\text { trabalho do CSNU. }\end{array}$ \\
\hline $\begin{array}{l}\text { Tomada de decisão do CSNU, inclusive manutenção, } \\
\text { limitação ou abolição do veto. }\end{array}$ & $\begin{array}{l}\text { Participação de membros não permanentes } \\
\text { no trabalho do CSNU. }\end{array}$ \\
\hline Revisão periódica do alargamento & Relação entre CSNU e AGNU e outros órgãos. \\
\hline
\end{tabular}

Fonte: elaboração própria com base em AGNU, $2004^{8}$.

Como demonstra o Quadro 1, o primeiro grupo de questões envolve o tamanho e a composição do CSNU, inclusive a respeito de membros permanentes, não permanentes e uma possível criação de novas categorias intermediárias. O segundo grupo de questões trata sobre métodos e procedimentos do órgão, sua eficiência e eficácia, e sua relação com outros órgãos da ONU.

O primeiro conjunto de questões é considerado o mais problemático, com questionamentos sobre a legitimidade do poder de veto, a possibilidade de exclusão dos mesmos ou de criação de novos poderes de veto, o que afronta os atuais membros permanentes. O grupo ficaria conhecido como never-ending Working Group, devido à dificuldade em se chegar a um acordo (LUCK, 2006). De toda maneira, temas relacionados à reforma do órgão foram tratados ao longo dos anos, debatidos e negociados entre o grupo de trabalho, em uma tentativa de criar um consenso, ou algo próximo, para elaboração de uma proposta que pudesse ser posta em votação na AGNU, criando maior pressão no CSNU9 .

Além desses temas relacionados à reforma formal do órgão, o grupo de trabalho também sugeriria alterações de regras de procedimento e métodos de trabalho, visando maior transparência, accountability e participação nos trabalhos do CSNU, tanto de outros membros da organização, em especial contribuintes das tropas das operações de paz, quanto da sociedade civil.

8 Para mais informações dos debates ao longo dos anos ver documentos AGNU, 2002; AGNU, 2004; AGNU, 2007; AGNU, 2008; AGNU, 2009.

9 Para maiores informações sobre a busca pela reforma formal ver: Baccarini, 2014; Mendes, 2015. 
Diversas alterações nos métodos de trabalho do órgão foram realizadas a partir de então. Uma das mais conhecidas é a Fórmula Arria, instituída com o fim da Guerra Fria pelo Embaixador Diego Arria, representante da Venezuela e presidente do Conselho em março de 1992. O primeiro desses encontros ocorreu devido ao interesse de um padre croata em levar ao Conselho seu testemunho sobre a violência que ocorria na Bósnia e Herzegovina. Pela ausência de um modelo de encontro, Diego Arria convidou-o para falar com os membros do Conselho no salão dos delegados do órgão, de maneira informal. Essa experiência exitosa deu ao embaixador a ideia de institucionalizar esse formato de encontros informais, que ficaria conhecido como "Fórmula Arria".

Tais reuniões, alteradas para o salão de conferências, provê o Conselho de informações de diferentes palcos dos conflitos por parte de atores que não órgãos da ONU. A Fórmula Arria é descrita no Suplemento dos Repertórios das Práticas do Conselho de Segurança de 1993-1995 como encontros não formais para ouvir as impressões de atores individuais, organizações ou instituições sobre assuntos que interessam ao CSNU. A forma seria de diálogo aberto com altos representantes de governos (posteriormente alterados para "encontros formais fechados") e organizações internacionais, representantes de atores não estatais, detentores de mandatos de monitoramento da Comissão de Direitos Humanos (atualmente do Conselho de Direitos Humanos), altos oficiais da ONU, representantes de ONGs e da sociedade civil. Tal método apresentou ascensão na década de 1990, com ligeira queda a partir dos anos 2000.

Surgiu, também, em 2009, como resposta ao interesse da delegação da União Africana e da Liga Árabe em discutir a condenação do presidente Omar-al-Bashir do Sudão pela Corte Criminal Internacional, um novo formato de diálogo: o Informal Interactive Dialogues. Esse formato difere de outros, em especial da Fórmula Arria, pois os diálogos tratam de uma situação específica, os participantes são oficiais, normalmente de alto nível, e o acesso é limitado aos membros do Conselho. Não são feitas gravações e, apesar de não haver resultados finais formais, podem haver pronunciamentos do Conselho.

Outra importante prática implementada foi a interação com contribuintes das operações de paz e o CSNU. Desde 1993, encontros informais são realizados e os contribuintes tentam influenciar a tomada de decisão, provendo informação sobre as operações de paz, mas sem procedimentos articulados formalmente. Reiteradas foram as tentativas do secretariado e de membros interessados em aprofundar essas interações por meio de consultas e encontros informais antes 
do órgão votar alguma resolução, seja para criação ou extensão das operações. Entretanto, apesar das declarações do CSNU cumprimentando as medidas (CSNU, 1994a; CSNU, 1994b; CSNU, 1996; CSNU, 1998), sua implementação sempre sofreu com impasses. Mesmo a criação, em decorrência da Cúpula Mundial de 2005, da Comissão das Operações de Paz (Peacebuilding Comission - PBC), o CSNU reluta em utilizá-lo como órgão consultivo ${ }^{10}$.

Já os wrap-up sessions correspondem à oportunidade de revisar o que foi feito durante o mês de uma presidência específica, discutir e refletir o futuro (S/2000/670) (CSNU, 2000). Inicialmente realizadas em encontros privados, foram alteradas para encontros públicos em resposta aos pedidos por maior transparência, accountability e disposição de informação. Normalmente realizadas por membros não permanentes, as wrap-up sessions se reduziram drasticamente a partir de 2003. Em 2012, a nota presidencial S/2012/922 (CSNU, 2012) sugeria sua retomada, o que ocorreu, sob a denominação enquanto item na agenda Implementation of Note S/2010/507. Os membros da ONU valorizam a oportunidade de ouvir em primeira mão os tópicos discutidos no CSNU em consultas fechadas e órgãos subsidiários. Além disso, há a expectativa de que essas sessões se tornem menos uma listagem dos pontos discutidos e se transformem em autoexame e reflexão da performance do órgão.

Ligado à diplomacia preventiva, os Horizon-Scanning Briefings, iniciados em 2010, correspondem a um esforço do secretário-geral em fornecer aos membros do Conselho um briefing político e de segurança focando nos riscos e conflitos potenciais. Um dos colaboradores principais seria o Departamento de Assuntos Políticos. Sua prática se assemelha aos relatórios diários que o secretário-geral, na década de 1990, distribuía aos membros do CSNU sobre questões que mereciam atenção do órgão, estando ou não na agenda oficial e que haviam sido abandonados. A ausência de um formato rotineiro para os briefings faz com que os mesmos, quando não programados, ocorram caso a caso, se tornando presos a questões procedimentais.

Em 2011, esses briefings passaram a ser realizados todos os meses, mas seu formato enfrentou resistências. Além disso, sua interatividade também foi gradativamente reduzida, assemelhando-se às consultas do órgão, em que os membros leem suas declarações. Em 2013, tornaram-se esporádicos e o próprio Departamento de Assuntos Políticos se desengajou, não mais buscando agendá-los. No final de 2013, o secretário-geral iniciou uma tentativa de reestruturá-los, focados

10 Para maiores informações específicas sobre as diversas alterações nos métodos de trabalho, vide Special Research Reports de 2007, 2010 e 2014, e o Updater Report de 2008, publicados pelo Security Council Report. 
agora na ação preventiva de responder a violações dos direitos humanos e prevenir atrocidades em massa.

A única forma reconhecida pelas regras de procedimentos provisórias do CSNU para comunicar alguma decisão é via resolução, sendo a posição dos membros observável pelos debates abertos e gravações de encontros. Entretanto, o órgão desenvolveu as declarações presidenciais e de imprensa, que se tornaram frequentes a partir da década de 1990.

As declarações presidenciais adquiriram status de decisão formal do CSNU. Inicialmente emitidas como cartas do presidente do CSNU ao secretário-geral, consolidaram-se sob o formato de nota presidencial, transmitindo uma declaração em nome do órgão. Podem ser reconhecidas pelo prefixo S/PRST/ e são listadas no relatório anual do CSNU à AGNU.

Em março de 2000, na ocasião do Dia Internacional da Mulher, os membros do CSNU iniciaram negociações para emitir uma declaração presidencial, mas, dada a oposição de alguns membros, a tática empregada foi de o presidente do órgão ler uma declaração para a imprensa, durante o briefing. A partir de então, as declarações de imprensa se tornaram mais constantes, podendo ser utilizadas para várias situações, como: 1) puramente factual, com pequenas declarações sobre o desenvolvimento de alguma atividade específica (que praticamente desapareceram após os membros do CSNU iniciarem aparições de mídia, arquivadas no site da ONU); 2) declarações sobre questões referentes às sanções (atualmente raras devido aos comitês de sanções, que elaboram suas próprias declarações); 3 ) declarações para eventos específicos, como atos terroristas, desastres naturais, morte de algum chefe de governo ou violência contra funcionários da ONU; 4) declarações como mensagens políticas, em momentos de eleições, de conferências internacionais etc.

É possível afirmar que o CSNU prefira uma declaração complexa à imprensa do que resoluções formais quando há inabilidade de se chegar a um acordo que possibilite o pronunciamento formal. Como as declarações de imprensa e presidenciais são consensuais, e não votadas, parece haver um trade-off entre conteúdo e forma. Em relação às declarações de imprensa, não existe diferenciação entre as mesmas e comunicados de imprensa regulares, que seriam mais informativos que substantivos, o que permite certo grau de flexibilidade e "ambiguidade construtiva”.

A nota presidencial S/2006/507 (CSNU, 2006) sobre métodos de trabalho, eficiência e transparência do órgão, de 2006, buscou clarificar os formatos e tipos de reuniões. Seriam eles ${ }^{11}$ :

11 Para maiores informações ver: CSNU,1999; CSNU, 2000; CSNU, 2010; CSNU, 2012; CSNU, 2013a; CSNU, 2013 b. 
- Encontros públicos:

Funções: tomar decisões e/ou realizar briefings e debates.

Participação: qualquer membro da ONU pode estar presente, sendo que qualquer um deles, membros do secretariado e outras pessoas podem ser convidadas a participar das discussões.

Tipos: a) open debate (não membros do CSNU podem ser convidados para participar da discussão); b) debates (não membros do CSNU diretamente relacionados ao assunto podem ser convidados para participar da discussão se solicitarem); c) briefing; d) adoption (não membros do CSNU também podem ou não ser convidados para participar da discussão).

- Encontros privados:

Funções: conduzir discussões ou tomar decisões, sem participação do público ou imprensa.

Participação: membros da ONU, do secretariado e outras pessoas podem ser convidadas a presenciarem ou participarem das discussões.

Tipo: a) private debate (membros da ONU, do secretariado e outras pessoas podem ser convidados a presenciar ou participar das discussões, a pedido do CSNU); b) TCC meeting (encontros com contribuintes de tropas das operações de paz, partes descritas na resolução RES/1353 de 2001 são convidadas para participar da discussão).

Em relação às resoluções, declarações presidenciais e de mídia do Conselho, os membros reafirmam na nota 507 que a todos deve ser permitido participar completamente de sua preparação, assim como da elaboração dos rascunhos. Além disso, reafirmam que continuarão com consultas informais com todos os membros da ONU, Estados diretamente envolvidos/afetados, vizinhos, organizações regionais e grupos de amigos para elaboração dos rascunhos, resoluções, declarações presidenciais, de mídia, conforme for apropriado. E concordam em tornar disponível esses rascunhos assim que sejam introduzidos nas consultas informais ou antes.

Apesar das intenções, a implementação da nota 507 foi desigual e dependente do interesse e energia de delegações. Considerações sobre formato das reuniões informais do CSNU e seus resultados foram levantadas no Grupo Informal de Trabalho, assim como a busca por maior interatividade nas Consultas Informais. Enquanto em 1994, no debate aberto, a preocupação em relação às Consultas Informais era decorrente de sua novidade e diminuição da ocorrência das negociações formais, em 2008, a preocupação se referia mais aos tipos de encontro, aos procedimentos de notificação e às oportunidades de input nos resultados do órgão. 


\section{A Implementação do sistema de comitês do CSNU}

Segundo Sartori (1994), a participação é relacionada com a fração do poder de tomada de decisão e sua frequência no processo, e os que não conseguem participar têm pouca possibilidade de exercer alguma função de controle, tendo em vista que, em pouquíssimos casos, os membros dos comitês são eleitos.

Assim, no processo de tomada de decisão do CSNU, desde sua criação, o comitê dos membros permanentes, o P5, prevalece. Durante a Guerra Fria, esse comitê não funcionou perfeitamente, tendo sido implementado um jogo de soma zero em decorrência da rivalidade entre as superpotências. Entretanto, dado o poder de veto, também não se estabelece a regra da maioria, e o CSNU trava.

Com o fim da Guerra Fria, o comitê entra em funcionamento, reduzem-se os vetos, e os membros permanentes alteram seu comportamento, conforme previsto pelos modelos informacionais e distributivos (MARTIN; SIMMONS, 1998). É implementado o jogo de soma positiva entre seus participantes, buscando acordos unânimes (evitando o poder de veto) a partir de possíveis trocas futuras e pagamentos laterais (SARTORI, 1994).

Compondo o sistema, outros comitês, como o Grupo de Amigos e os órgãos subsidiários, também são formados, visando maior participação tanto dos membros não permanentes quanto de outros membros da ONU ou mesmo de atores não estatais. Enquanto o primeiro tem formulação ad hoc, dependente do secretáriogeral e do tema em questão, os órgãos subsidiários são compostos por todos os membros do CSNU, sob a liderança de um membro não permanente (com exceção do Military Staff Committee e Peace Building Comission), apesar do P5, em muitos desses órgãos, serem os vice-presidentes (SECURITY COUNCIL REPORT, 2007; SECURITY COUNCIL REPORT, 2008).

Com o aumento do número de questões tratadas pelo Conselho, os rascunhos, antes elaborados por qualquer membro, sofreram uma divisão de trabalho, emergindo um sistema de Grupos de Amigos. Membros com interesse, comprometidos ou envolvidos em determinada questão elaboravam conjuntamente o rascunho das resoluções, sendo liderados por um membro permanente ou não permanente, podendo, inclusive, envolver não membros.

Idealmente, a formação desses comitês viria para contrabalancear o peso do P5 no processo decisório, visando aumentar o input dos membros não permanentes e não membros do CSNU. Entretanto, apesar de aparentemente mais democráticos, alguns membros permanentes acreditavam que aqueles grupos, cujo papel de líder 
era realizado por um não P5, contribuíam para diminuir sua autoridade. Além disso, alguns membros questionavam o envolvimento de não membros antes mesmo da questão ser analisada pelos membros do Conselho (CSNU, 1999).

Entretanto, em 2010, um novo método emerge em que os membros permanentes ocidentais (P3) dividem grande parte da agenda entre eles, assumindo o papel de penholder. Dos 50 arranjos de penholder de 2014, correspondentes à seizure list (lista de assuntos sobre os quais o Conselho não chegou a um acordo), 34 eram lideradas pelo P3 (França com 8, Inglaterra com 11 e EUA com 15), Rússia liderava mais 3 e os Grupos de Contato e Grupos de Amigos ficaram com os 11 restantes, a maioria questões temáticas, lideradas por um membro não permanente.

De acordo com o Security Council Report (2016), possivelmente a demora em se adotar uma resolução sobre a não proliferação nuclear em 2006 em relação à Coreia do Norte e Irã fez surgir esse método de tomada de decisão. Inicialmente adotado somente para questões de não proliferação, gradualmente o sistema de penholder foi sendo estendido para outras questões da agenda, afetando, inclusive, a participação de presidentes de comitês sanções (SECURITY COUNCIL REPORT, 2016).

O sistema aprofundou a lacuna de negociação e consultas entre P5 e E10. Desde então, inicialmente o P3 negocia entre si e, após um acordo, leva o rascunho para aprovação de Rússia e China. Com um consenso entre o P5, a questão é levada ao E10, perto da data da aprovação final. Membros não permanentes são desencorajados a fazer emendas substantivas, dados os esforços despendidos entre os membros com poder de veto de chegar a um acordo quanto à redação (SECURITY COUNCIL REPORT, 2010; SECURITY COUNCIL REPORT, 2014). Por sua vez, os membros não permanentes não coordenam suas ações, de forma a aumentar sua importância decisória, nem vêm demonstrando real interesse em liderar os debates sobre determinado rascunho, restringindo-se a aceitar a presidência de órgãos subsidiários.

A falta de interatividade é a nova tendência. Enquanto várias atitudes foram tomadas pelo CSNU e Secretariado para tornar as informações mais acessíveis e inteligíveis, a acessibilidade do órgão reduziu nos últimos anos. Para além da força inerente do comitê do P5, com poder de veto na tomada de decisão, um subcomitê formado pelo P3 (EUA, Inglaterra e França) detém o controle da agenda, evitando a necessidade de vetos (SECURITY COUNCIL REPORT, 2010; SECURITY COUNCIL REPORT, 2014). 
Como os penholders tomam a liderança para a elaboração dos rascunhos, normalmente passam por cima dos presidentes dos órgãos subsidiários, mesmo que esses sejam escolhidos pelos membros permanentes após consultas informais e bilaterais com o E10 (SECURITY COUNCIL REPORT, 2010; SECURITY COUNCIL REPORT, 2014).

Tal sistema ocasiona paralisia do órgão e atraso na tomada de decisão em casos emergenciais quando os penholders não se interessam ou não podem tomar a iniciativa, influenciando na efetividade do Conselho. Reações por parte de alguns Estados possibilitaram algum relaxamento do sistema a partir de 2013, com Austrália e Luxemburgo tendo um papel mais atuante em relação aos aspectos humanitários na Síria. Com as eleições posteriores, foram substituídos nessa temática por Jordânia, Nova Zelândia e Espanha, e Egito em $2016^{12}$ (SECURITY COUNCIL REPORT, 2016). Reações por parte da presidência do órgão também foram formalizadas, em especial por uma maior participação dos presidentes dos órgãos subsidiários (CSNU, 2016).

Como exemplo da força do sistema de penholders, das atuais 39 situações/ áreas temáticas analisadas pelo Conselho de Segurança, 24 estão sob controle do P3 por meio de seus penholders e mais duas têm envolvimento direto dos Estados Unidos e outro(s) Estado(s). Assim, em dois terços das questões tratadas pelo órgão, França, Reino Unido e Estados Unidos dominam a elaboração de rascunhos das decisões. Outras duas situações/áreas temáticas estão sob o controle da Rússia, totalizando 28 sob o jugo do P5 (ou 71,8\%). Somente sete situações/ áreas temáticas têm como penholder um país que não seja membro permanente (18\%), e duas (Haiti e Síria) sob um controle conjunto de diversos Estados (5\%) (SECURITY COUNCIL REPORT, 2017). Por outro lado, todas as decisões tomadas no órgão esse ano, 2017, foram consensuais (15-0-0), ocorrendo, em dois casos, vetos de Rússia e China em draft resolutions sobre o Oriente Médio (CSNU, 2017).

Não há dúvidas de que o consenso que emerge no fim da Guerra Fria está em direta relação com o surgimento e proliferação dos comitês. Entretanto, ao contrário do que se esperava, a cooperação e o jogo de soma positiva parece se estabelecer mais entre os membros permanentes do que entre todos os membros do órgão.

Assim, iniciativas visando maior participação e transparência no trabalho do CSNU possibilitaram, em alguns momentos, maior influência no processo de

12 Em relação a outras decisões influenciadas por membros não permanentes, não participantes do sistema de penholder, podemos citar: Venezuela na organização do debate sobre o uso de sanções; Egito, Japão, Nova Zelândia, Uruguai e Venezuela na questão de cuidado com a saúde em conflitos armados; Nova Zelândia em relação à Síria etc. 
tomada de decisão de outros grupos. Entretanto, essa influência parece estar mais relacionada à disposição e interesse dos membros permanentes de cooperarem entre si. O consenso decisório é, atualmente, resultante do equacionamento dos interesses de diferentes intensidades entre o P5, tendendo a beneficiar prioritariamente tais atores, como demonstra as sucessivas declarações do E10 que, mesmo incluídos pela regra formal no processo de tomada de decisão, têm seu papel substancialmente reduzido nas negociações, e buscam maior participação na tomada de decisão, em especial na elaboração dos rascunhos.

Enquanto continuação desse artigo, faz-se necessária uma análise empírica mais detalhada para estabelecer correlação e relação causal entre as diversas variáveis apresentadas. Como o sistema de penholder é relativamente recente, com pequena quantidade de dados disponíveis, dificulta-se a realização de uma correlação estatística entre as variáveis "quantidade de decisões tomadas por meio de sistema de penholder" e "consenso decisório".

Além disso, como apontado ao longo do texto, várias foram as evoluções nos métodos de trabalho do órgão (Fórmula Arria, Fórmula Somália, encontros informais diversos etc.) e nos comitês desde o fim da Guerra Fria (P3, P5, Grupo de Amigos, órgãos subsidiários etc.). Para uma análise profunda e detalhada, seria necessário correlacionar a variável "consenso decisório" com todos os métodos de trabalho e comitês que, em determinado momento, tiveram relativa influência, analisando historicamente quando cada um deles perde força enquanto outro apresenta maior poder explicativo.

\section{Conclusões}

A participação no processo de tomada de decisão do Conselho de Segurança da ONU é tema sensível e sujeito a controvérsias, ocasionando debates, em especial na Assembleia Geral, por uma reforma do órgão. Dadas as complexas e infrutíferas negociações acerca da possibilidade de alteração das regras decisórias, Estados não totalmente satisfeitos com sua participação vêm estrategicamente buscando alterar os métodos de trabalho do órgão, de forma a garantir maior oportunidade de inputs, em especial de encaminhamento de suas demandas, para que os outputs, em alguma medida, reflitam seus interesses.

Desde o fim da Guerra Fria, essas alterações resultaram em uma mudança no padrão de votação do CSNU, que deixa de se pautar pela regra da maioria, 
em um jogo de soma zero entre as potências e seus aliados, e inicia um processo decisório de votação consensual em que cerca de $90 \%$ das decisões são tomadas por consenso. Aparentemente mais cooperativo, esse processo se caracteriza pela formação de comitês de decisão, em que os dois principais são o P5, formado pelos membros permanentes, e o P3, formado pelos membros permanentes ocidentais, que controlam o poder de agenda. Nesse jogo de soma positiva, os atores passam a cooperar uns com os outros tendo em vista suas diversas intensidades de preferências.

No sistema de comitês do processo decisório do CSNU, outros comitês também são constituídos, visando incluir novos atores, inclusive os próprios membros não permanentes, mas mesmo os órgãos subsidiários parecem deter pouca influência no processo, que segue dominado pelos membros permanentes.

Dessa forma, apesar do surgimento do sistema de comitês no processo decisório do CSNU, que altera o padrão decisório - de relativamente conflitivo para consensual, o que se pode observar é a prevalência do P3 e do P5, estando os outros comitês dependentes da disposição e interesse dos penholders de incluí-los nas decisões.

Entretanto, contraditoriamente ao esperado com o fortalecimento do sistema de penholder, a partir de 2015 observa-se maior aceitação de votações não consensuais, tendência ainda a ser analisada.

\section{Referências}

ASSEMBLEIA GERAL DAS NAÇÕES UNIDAS. A/56/47, 2002. Disponível em: < https://documents-dds-ny.un.org/doc/UNDOC/GEN/N02/438/32/pdf/N0243832. pdf?OpenElement $>$. Acessado em 07 de fevereiro de 2017.

ASSEMBLEIA GERAL DAS NAÇÕES UNIDAS. A/58/47, 2004. Disponível em: < https://documents-dds-ny.un.org/doc/UNDOC/GEN/N04/417/02/pdf/N0441702. pdf?OpenElement $>$. Acessado em 07 de fevereiro de 2017.

ASSEMBLEIA GERAL DAS NAÇÕES UNIDAS. A/61/47 (SUPP), 2007. Disponível em: $<$ https://documents-dds-ny.un.org/doc/UNDOC/GEN/N07/509/21/pdf/N0750921. pdf?OpenElement $>$. Acesso em: 09 de fevereiro de 2017.

ASSEMBLEIA GERAL DAS NAÇÕES UNIDAS. A/62/ 47 (SUPP), 2008. Disponível em: $<$ https://documents-dds-ny.un.org/doc/UNDOC/GEN/N08/524/30/pdf/N0852430. pdf?OpenElement $>$. Acesso em: 09 de fevereiro de 2017. 
ASSEMBLEIA GERAL DAS NAÇÕES UNIDAS. A/63/ 47 (SUPP), 2009. Disponível em: < https://documents-dds-ny.un.org/doc/UNDOC/GEN/N09/508/11/pdf/N0950811. pdf?OpenElement > . Acessado em 09 de fevereiro de 2017.

BACCARINI, M. P. O. A reforma do Conselho de Segurança das Nações Unidas: uma questão institucional. 2014. Tese de Doutorado. Universidade Federal de Minas Gerais, Minas Gerais, 2014. Disponível em: http://www.bibliotecadigital.ufmg.br/dspace/ bitstream/handle/1843/BUOS-9LNHCP/mariana_baccarini_tese_vers_o_final. pdf? sequence $=1$. Acessado em 05 de junho de 2017 .

BUZAN, Barry. Negotiating by Consensus: Developments in Technique at the United Nations Conference on the Law of the Sea. American Journal of International Law, vol. 75, n. 2, 1981, p. 324-348. Disponível em: < https://www.jstor.org/stable/2201255? seq $=1$ \#page_scan_tab_contents $>$. Acesso em: 07 de fevereiro de 2017 .

CONSELHO DE SEGURANÇA DAS NAÇÕES UNIDAS. S/ PRST/1994/22, 1994a. Disponível em: < https://documents-dds-ny.un.org/doc/UNDOC/GEN/N94/202/90/pdf/N9420290. pdf?OpenElement $>$. Acessado em 07 de fevereiro de 2017.

CONSELHO DE SEGURANÇA DAS NAÇÕES UNIDAS. S/ PRST/1994/62, 1994b. Disponível em: $<$ https://documents-dds-ny.un.org/doc/UNDOC/GEN/N94/432/25/pdf/N9443225. pdf?OpenElement $>$. Acessado em 07 de fevereiro de 2017.

CONSELHO DE SEGURANÇA DAS NAÇÕES UNIDAS. S/ PRST/1996/13, 1996. Disponível em: < https://documents-dds-ny.un.org/doc/UNDOC/GEN/N96/075/24/pdf/N9607524. pdf?OpenElement $>$. Acessado em 07 de fevereiro de 2017.

CONSELHO DE SEGURANÇA DAS NAÇÕES UNIDAS. S/1998/1016, 1998. Disponível em: < https://documents-dds-ny.un.org/doc/UNDOC/GEN/N98/331/07/pdf/N9833107. pdf?OpenElement $>$. Acessado em 07 de fevereiro de 2017.

CONSELHO DE SEGURANÇA DAS NAÇÕES UNIDAS. S/1999.165, 1999. Disponível em: < https://documents-dds-ny.un.org/doc/UNDOC/GEN/N99/041/85/pdf/N9904185. pdf?OpenElement $>$. Acessado em 07 de fevereiro de 2017.

CONSELHO DE SEGURANÇA DAS NAÇÕES UNIDAS. S/2000/670, 2000. Disponível em: < https://documents-dds-ny.un.org/doc/UNDOC/GEN/N00/584/18/pdf/N0058418. pdf?OpenElement $>$. Acessado em 07 de fevereiro de 2017.

CONSELHO DE SEGURANÇA DAS NAÇÕES UNIDAS. S/2006/507, 2006. Disponível em: < https://documents-dds-ny.un.org/doc/UNDOC/GEN/N06/435/44/pdf/N0643544. pdf?OpenElement $>$. Acessado em 07 de fevereiro de 2017.

CONSELHO DE SEGURANÇA DAS NAÇÕES UNIDAS. S/2010/507, 2010. Disponível em: < https://documents-dds-ny.un.org/doc/UNDOC/GEN/N10/464/16/pdf/N1046416. pdf?OpenElement $>$. Acessado em 07 de fevereiro de 2017.

CONSELHO DE SEGURANÇA DAS NAÇÕES UNIDAS. S/2012/922, 2012. Disponível em: < https://documents-dds-ny.un.org/doc/UNDOC/GEN/N12/647/60/pdf/N1264760. pdf?OpenElement > . Acessado em 07 de fevereiro de 2017. 
CONSELHO DE SEGURANÇA DAS NAÇÕES UNIDAS. S/2013/142, 2013a. Disponível em: < https://documents-dds-ny.un.org/doc/UNDOC/GEN/N13/254/99/pdf/N1325499. pdf?OpenElement $>$. Acessado em 07 de fevereiro de 2017.

CONSELHO DE SEGURANÇA DAS NAÇÕES UNIDAS. S/2013/152, 2013b.Disponível em: < https://documents-dds-ny.un.org/doc/UNDOC/GEN/N13/257/48/pdf/N1325748. pdf?OpenElement $>$. Acessado em 07 de fevereiro de 2017.

CONSELHO DE SEGURANÇA DAS NAÇÕES UNIDAS. S/2016/170, 2016.Disponível em: < https://documents-dds-ny.un.org/doc/UNDOC/GEN/N16/046/21/pdf/N1604621. pdf?OpenElement $>$. Acessado em 07 de fevereiro de 2017.

CONSELHO DE SEGURANA DAS NAÇÕES UNIDAS. Meeting Records, 2017. Disponível em: < http://www.un.org/en/sc/meetings/records/2017.shtml > .

DINIZ, E.; BACCARINI, M. UN Security Council Decision-Making: Testing the Bribery Hypothesis. Revista Brasileira de Política Internacional, vol. 57, n. 2, 2014, p. 29-57. Disponível em: http://www.scielo.br/pdf/rbpi/v57n2/0034-7329-rbpi-57-02-00029. pdf. Acessado em 02 de junho de 2017.

DREHER, A; STURM, J; VREELAND, J. Global horse trading: IMF loans for votes in the United Nations Security Council. European Economic Review, vol. 7, n. 57, 2009a, p. 742-757. Disponível em: < https://ideas.repec.org/a/eee/eecrev/v53y2009i7 p742-757.html > . Acessado em 07 de fevereiro de 2017.

DREHER, A; STURM, J; VREELAND, J. Development aid and international politics: Does membership on the UN Security Council influence World Bank decisions?. Journal of Development Economics, n.88, 2009b, p. 1-18,. Disponível em: < https://www. researchgate.net/publication/222814643_Development_Aid_and_International_ Politics_Does_Membership_on_the_UN_Security_Council_Influence_World_Bank_ Decisions > . Acessado em 09 de fevereiro de 2017.

EASTON, D. An Approach to the Analysis of Political Systems. World Politics, vol. 9, n. 3, 1957, p. 383-400. Disponível em: < http://online.sfsu.edu/sguo/Renmin/June2_ system/Political\%20System_Easton.pdf > . Acessado em 18 de setembro de 2017.

HOSLI, M. O., et al. Squaring the Circle? Collective and Distributive Effects of United Nations Security Council Reform. In: 52nd Annual Convention of the International Studies Association, 2011, Montreal. Anais Eletrônicos.

HURD, Ian. Security Council Reform: Informal Membership and Practice. In. RUSSETT, Bruce, The Once and Future Security Concil. 1. Ed. New York: St. Martin's Press, 1997, Cap. 7.

KUZIEMKO, I.; WERKER, E. How Much is a Seat on the Security Council Worth? Foreign Aid and Bribery at the United Nations. Journal of Political Economy, v. 114, n. 5, 2006, p. 905-930. Disponível em: http://scholar.princeton.edu/sites/default/files/ kuziemko/files/kuziemko_werker.pdf. Acessado em 02 de junho de 2017.

LUCK, Edward C. UN Security Council: Practice and Promise. Nova York:Routledge, 2006. 
MARTIN, Lisa; SIMMONS, Beth. Theories and Empirical Studies of International Institutions., International Organization, vol. 4, n. 52, 1998, p. 729-757. Disponível em: < https://dash.harvard.edu/bitstream/handle/1/3382862/Theories_Empirical. pdf? sequence $=2>$. Acessado em 09 de fevereiro de 2017 .

MENDES, Flávio Pedroso. O Brasil e a reforma do Conselho de Segurança: Uma análise realista. Contexto Internacional, Rio de Janeiro, vol. 37, no 1, janeiro/abril, 2015, p.113-142. Disponível em: http://www.scielo.br/scielo.php?script = sci_arttext\&pid = S0102-85292015000100113. Acessado em 05 de junho de 2017.

O'NEILL, B. Power and Satisfaction in the United Nations Security Council. Journal of Conflict Resolution, vol.2, n. 40, 1996, p. 219-237. Disponível em: < https://www. jstor.org/stable/174351 > . Acessado em 07 de fevereiro de 2017.

ORGANIZAÇÃO DAS NAÇÕES UNIDAS. UNSecurity Council Voting Records, 2013. Recuperado em 10 de Julho de 2013, do site: http://unbisnet.un.org:8080/ipac20/ ipac.jsp?profile $=$ voting\&menu $=$ search\&submenu $=$ power\#focus .

PRANTL J. The UN Security Council and Informal Groups of States: Complementing or Competing for Governance? (1.Ed). New York, NY, EUA: Oxford University Press, 2006. RITTBERGER, Volker; ZANGL, Bernhard; STAISCH, Matthias. International Organizations: polity, politics and policies. Palgrave: Macmillan, 2006.

SARTORI, Giovanni. A Teoria da Democracia Revisitada: o debate contemporâneo. São Paulo: Ed. Ática, 1994.

SECURITY COUNCIL REPORT. Monthly Forecast: In Hindsight: The Security Council Penholders, 2016. Acessado em 06 de fevereiro de 2017. Disponível em: < http://www. securitycouncilreport.org/monthly-forecast/2016-10/in_hindsight_the_security_ council_penholders.php > .

SECURITY COUNCIL REPORT. Special Research Report. Security Council transparency, legitimacy and effectiveness: Efforts to Reform Council Working Methods 1993-2007, n. 3, 2007. Disponível em: < http://www.securitycouncilreport.org/special-researchreport/lookup-c-glKWLeMTIsG-b-3506555.php > . Acesso em: 07 de fevereiro de 2017. SECURITY COUNCIL REPORT. Update Report: Security Council Working Methods, n. 1, 2008. Disponível em: < http://www.securitycouncilreport.org/update-report/ lookup-c-glKWLeMTIsG-b-4420143.php > . Acessado em 07 de fevereiro de 2017.

SECURITY COUNCIL REPORT. Special Research Report. Security Council Working Methodsa work in progress, n. 1, 2010. Disponível em: < http://www.securitycouncilreport. org/special-research-report/lookup-c-glKWLeMTIsG-b-5906427.php > . Acessado em 07 de fevereiro de 2017.

SECURITY COUNCIL REPORT. Special Research Report. Security Council Working Methods: a tale of two councils?, n. 1, 2014. Disponível em: < http://www.securitycouncilreport. org/special-research-report/security-council-working-methods-a-tale-of-two-councils. php > . Acessado em 07 de fevereiro de 2017. 
SECURITY COUNCIL REPORT. 2017 Chairs of Subsidiary Bodies and Penholders, 2017. Disponível em: http://www.securitycouncilreport.org/un-security-councilworking-methods/atf/cf/\% 7B65BFCF9B-6D27-4E9C-8CD3-CF6E4FF96FF9\% 7D/ Penholders \% 20and \% 20Subsidiary \%20Body\%20Chairs.pdf. Acessado em 23 de agosto de 2017.

WEISS, T.G. The Illusion of UN Security Council Reform. The Washington Quaterly, vol.4, n.26, 2003, p. 147-161. 


\title{
Aspectos normativos, securitários e geopolíticos da grande estratégia da Rússia (2000-2016) e o lugar das Nações Unidas
}

\section{Normative, security and geopolitical aspects of Russian grand strategy (2000-2016) and the UN's place}

DOI: $10.21530 /$ ci.v12n2.2017.629

Bruno Gomes Guimarães ${ }^{1}$

\section{Resumo}

O trabalho visa examinar a política externa e de segurança da Rússia durante os governos Putin (2000-2008 e 2012-2016) e Medvedev (2008-2012) para descobrir seus aspectos normativos, securitários e geopolíticos e o lugar da Organização das Nações Unidas (ONU) na grande estratégia russa. Divide-se a pesquisa em três seções. A primeira traça um breve histórico da grande estratégia da Rússia. Já a segunda trata de seus aspectos normativos: a sua concepção de legitimidade na ordem internacional, ativismo global, concepção de soberania e processos de integração regional. Na terceira parte, são analisados os aspectos securitários e geopolíticos, tais como guerras e intervenções militares, participação em operações de paz da ONU, doutrina militar e mecanismos regionais de segurança. Conclui-se que a ONU, na grande estratégia russa, seria central à ordem internacional ao solidificar as instituições que mantêm a estabilidade desta e ao assegurar o status russo de grande potência.

Palavras-chave: Rússia; Grande estratégia; Organização das Nações Unidas

\begin{abstract}
This paper examines the Russian foreign and security policy of Putin (2000-2008 and 2012-2016) and Medvedev (2008-2012) to discover its normative, security, and geopolitical aspects as well as the place of the United Nations in its grand strategy. The work is divided

1 Programa de Pós-Graduação em Estudos Estratégicos Internacionais da Faculdade de Ciências Econômicas da Universidade Federal do Rio Grande do Sul, Porto Alegre/RS, Brasil. E-mail: bgguima@gmail.com

O autor gostaria de agradecer aos/às revisores/as por seus valiosos apontamentos que auxiliaram no aperfeiçoamento do trabalho, bem como os comentários e indicações das/dos colegas Marcela Ávila, Larlecianne Piccolli, Willian Moraes Roberto, Valeska Monteiro e Luiz Mocelin na fase de pesquisa e escrita.
\end{abstract}

Artigo submetido em 12/02/2017 e aprovado em 19/07/2017. 
into three sections. The first briefly tracks the record of Russia's grand strategy. The second copes with its normative aspects: its conception of legitimacy in the world order, global activism, notion of sovereignty, and regional integration processes. The third part delves into geopolitical and security issues, such as wars and military interventions, participation in UN peace operations, military doctrine, and regional security arrangements. It concludes the UN, according to Russia's grand strategy, is central to the world order by solidifying institutions that uphold its stability and by maintaining Russian great power status.

Keywords: Russia; Grand strategy; United Nations

\section{Introdução}

No advento do século XXI, as relações internacionais passaram por significativas transformações sistêmicas. Se, logo ao fim da Guerra Fria, dizia-se que o sistema internacional passava por um momento unipolar, da década de 2000 em diante a multipolaridade vem se assentando cada vez mais, notadamente após a crise econômica de 2007-2008 (VIZENTINI, 2004; KHANNA, 2008; BRZEZINSKI, 2012). Brasil, Índia, China, Rússia e África do Sul (BRICS), entre outros, despontam como atores de grande peso para o sistema internacional e abrem perspectivas de mudanças para a ordem mundial liberal representada pelo domínio dos Estados Unidos da América (EUA) e, em menor grau, da União Europeia (UE) e do Japão (KORNEGAY, 2013; MARTINS, 2013). As interações entre esses atores serão fatores fundamentais para a evolução da ordem internacional contemporânea, pois, como colocam Carlos Teixeira e Reginaldo Nasser (2010, p. 175), “as diferentes percepções em torno da construção de uma ordem mundial implicam opções políticas distintas na resolução dos problemas que se manifestam no sistema internacional". ${ }^{2}$ De fato, como informa Henry Kissinger (2014), as ordens internacionais mais estáveis são aquelas em que as percepções dos atores são mais semelhantes. Porém, as disputas normativas e geopolíticas entre as potências emergentes e as tradicionais já demonstram uma gradual erosão da relativa estabilidade da atual ordem internacional, como os casos das crises na Síria e na Ucrânia, tentativas de mudança de regime e "revoluções coloridas", bem como os debates sobre a responsabilidade de proteger (R2P) com a possível mudança no conceito de

2 A ordem internacional, mundial ou global nada mais é do que as características estruturais do sistema internacional que emergem a partir da interação entre os vários Estados, grupos e sociedades humanas ao longo do tempo e que geram constrangimentos às ações dos atores no sistema internacional (CEPIK, 2014; CEPIK; MACHADO, 2011). 
soberania atestam (CARMONA, 2014; ROTMANN; KURTZ; BROCKMEIER, 2014). A Rússia é um ator central nessas disputas. Ela é fundadora da Organização das Nações Unidas (ONU) com privilégio de ser membro permanente de seu Conselho de Segurança (CSNU) e ter poder de veto, estando sempre presente em negociações e debates acerca da ordem internacional. Moscou, ademais, tem interesses diretos nos resultados dessas discussões. Isso frequentemente a coloca em oposição aos EUA e UE, como, por exemplo, nos debates sobre a intervenção na Líbia, Iraque e na Síria e em negociações de paz da Ucrânia. Além disso, convém lembrar que atualmente a Rússia é um dos países do sistema internacional com mais capacidades (CEPIK, 2014), ainda que haja uma preeminência estadunidense sobre os demais (BRZEZINSKI, 2012; NYE, 2012), sendo considerada uma grande potência ${ }^{3}$. Por causa disso, a sua posição é fundamental para a estabilidade e manutenção da ordem mundial, representadas pelo conjunto do sistema ONU. A ONU, como qualquer outra organização internacional, como bem lembra o teórico Kenneth Waltz (1999), tem que ser mantida por alguém. A importância russa para a manutenção dela evidencia-se no fato de que Moscou é o nono maior contribuidor para o orçamento geral da organização - atrás somente dos países do Norte global, China e Brasil - e o sétimo do orçamento exclusivo para operações de paz (UN, 2014; 2015).

Considerando a importância da Rússia tanto para a ordem internacional em geral quanto para a ONU em particular, é necessário compreender os interesses e as ações do país para avaliar sua influência nas disputas que envolvem as instituições-base da ordem internacional (e da organização). Ademais, como salienta Andrei Tsygankov (2012), precisa-se entender a Rússia para além da narrativa rasteira de que o país é apenas um país autoritário e agressivamente expansionista por tradição (e.g. KAGAN, 2017; DUNN; BOBICK, 2014; VALKOV, 2014). Portanto, o objetivo deste artigo é descobrir e discutir o papel da ONU na "grande estratégia” da Rússia ao longo do século XXI.

A abordagem utilizada para a análise dessa questão será a da escola inglesa de relações internacionais. Segundo essa perspectiva teórica, embora a ONU não sustente a ordem internacional e sim o contrário, ela é resultado da

3 Grandes potências são aquelas com as maiores capacidades do sistema. Contemporaneamente, as características de uma grande potência são as capacidades estratégicas de segundo ataque (dissuasão nuclear), o comando do espaço e a inexpugnabilidade frente a ataques convencionais - fatores determinantes para o uso da força na era digital (CEPIK, 2014). Sendo assim, Rússia e China, além dos EUA, seriam grandes potências, tornando a ordem internacional tripolar ou multipolar, ainda que de forma acentuadamente assimétrica (CEPIK, 2014). 
institucionalização da sociedade internacional ${ }^{4}$ tal como ela era em 1945 (PARRAT, 2014). A ordem internacional da época se fundamentava nos princípios normativos do sistema de Westfália, ou seja, na soberania nacional, na não interferência em assuntos domésticos, na independência e nos interesses nacionais. Ela caracterizavase por tais instituições ${ }^{5}$ que garantem um sistema de Estados independentes que procuram evitar interferir em assuntos internos e conter as ambições de outros Estados através de uma balança de poder (KISSINGER, 2014). A Carta da ONU representa o reconhecimento dessas instituições e normas westfalianas por parte dos Estados-membros. De um lado, a Assembleia Geral garantiu a igualdade soberana dos Estados. Por outro, o Conselho de Segurança das Nações Unidas (CSNU) é o órgão que cimentou a importância da manutenção de determinada balança de poder entre as grandes potências como modo de garantir a paz no mundo. ${ }^{6}$ Então, é possível notar que a organização cristalizou e simboliza algumas das principais instituições que mantêm a estabilidade da ordem internacional: o gerenciamento da ordem pelas grandes potências; o equilíbrio de poder; a soberania e não intervenção; o direito internacional; e a própria diplomacia (PARRAT, 2014). A analista Charlotta Parrat (2014) nota que a inter-relação dessas instituições no seio da ONU é muitas vezes conflituosa - entre a hierarquização de Estados (grandes potências estando acima dos demais) e a completa equivalência entre eles (a igualdade soberana) — , o que fica evidenciado nos debates da reforma da organização. A autora explica que o choque entre essas instituições cria impasses, ainda que recentemente uma nova instituição venha sendo usada para mediação: a representação regional (ou igualdade entre regiões) (PARRAT, 2014).

4 Sociedade internacional é “um grupo de Estados (ou, mais geral, um grupo de comunidades políticas independentes) que não apenas forma um sistema, no sentido de que o comportamento de cada um é um fator necessário para os cálculos dos outros, mas que também estabeleceu através do diálogo e do consenso regras e instituições comuns para a conduta de suas relações e que reconhece seu interesse comum em manter esses arranjos" (BULL; WATSON, 1984, p. 1 apud DUNNE, 2013, p. 6).

5 Instituições internacionais são hábitos e práticas que tomam forma para a realização de objetivos comuns dos Estados e ajudam a tornar as normas internacionais mais efetivas (BULL, 2002). Para uma discussão ampla da escola inglesa sobre as instituições primárias que sustentam a ordem internacional, ver Bull (2002), Buzan (2014) e Schouenborg (2014). Nessa concepção, a ONU seria uma instituição secundária (SCHOUENBORG, 2014).

6 De fato, é esse balanceamento entre normas e poder que está no cerne da ordem global. Kissinger (2014) diz que a estabilidade de uma ordem internacional depende do equilíbrio alcançado entre legitimidade e poder: um conjunto de regras que define o que é permitido fazer e que seja aceito por todos, por um lado, e uma balança de poder que sirva para conter as situações em que essas regras são violadas, por outro. Esse equilíbrio, no entanto, não é estático e, se bem gerenciado, garante que mudanças na ordem mundial ocorram de forma gradual e sem grandes conflitos (KISSINGER, 2014). De forma semelhante, Hedley Bull (2002) nota que, para ser duradoura, a ordem internacional deve, em alguma medida, responder a demandas por mudanças tidas como justas e, por outro lado, a exigência dessas mudanças deve levar em conta a manutenção da ordem. 
Como recomenda Schouenborg (2014), estudar instituições sob a ótica da escola inglesa requer atenção tanto em relação ao que os Estados (e estadistas) dizem e pensam quanto às suas ações. Dessa forma, a "grande estratégia" é o fator a ser considerado enquanto conceito analítico, porque ela leva em conta as duas facetas. Mas o que vem a ser "grande estratégia”? Segundo Stephen Krasner (2010, tradução própria7), "grande estratégia” é um conceito que "descreve como o mundo é, visiona como ele deve ser e especifica um conjunto de políticas que possam atingir essa orientação" e contém tanto questões de poder quanto de crenças. A grande estratégia é o "nível mais alto e abrangente de estadismo, diplomacia e política” - é a estratégia máxima para as ações e a existência do Estado (MARTEL, 2015, p. 51). Ela envolve a coordenação de fins e meios no longo prazo, levando em conta a possibilidade ou mesmo existência de conflitos armados (PORTER, 2013). A conexão entre fins e meios é onde a grande estratégia se encontra:

[Grande] Estratégia é, portanto, distinta tanto da política pública (o resultado desejado) quanto de operações (o exercício ou uso das ferramentas ou a relação entre vias e meios, tal como a condução de campanhas militares). Ela é melhor concebida não como um ator ou uma "coisa" identificáveis, mas como a ponte que funde ou relaciona todas elas juntas (PORTER, 2013, p. 5, tradução própria ${ }^{8}$.

Assim, a "grande estratégia" visa moldar o ambiente externo para garantir a segurança das instituições políticas, integridade territorial, estilo de vida e valores do Estado e sua sociedade (PORTER, 2013). Esse objetivo pode se dar através da regulação de regimes internacionais, da influência sobre as escolhas políticas dos demais Estados ou mesmo sobre seus regimes como um todo (KRASNER, 2010). Aqui fica evidente que a grande estratégia dos países é um importante fator para ser levado em conta em análises de relações internacionais, segurança internacional e defesa. Além disso, a incorporação da grande estratégia aos estudos da escola inglesa de RI pode tornar mais robusto seu instrumental analítico. Por fim, a grande estratégia da Rússia é particularmente crucial para a compreensão da atual ordem mundial, porque informa sobre muitos dos debates e disputas

7 No original: "A grand strategy is a conceptual framing that describes how the world is, envisions how it ought to be, and specifies a set of policies that can achieve that ordering."

8 No original: “[Grand] Strategy is thus distinct from both policy (the desired outcome) and operations (the exercise or use of the tools or the relationship between ways and means, such as the conduct of military campaigns). It is best conceived not as an identifiable actor of 'thing,' but as the bridge that fuses or relates them all together." 
contemporâneos e também porque Moscou tem grande capacidade de influenciar essa mesma ordem, especialmente a ONU, como já foi dito.

Entretanto, como assinala William Martel (2015), a grande estratégia não é pensada e conduzida de forma puramente racional e desvinculada de um contexto histórico e político; ela surge de tradições e da geopolítica e entranha-se nas instituições do Estado. ${ }^{9}$ O fim da União das Repúblicas Socialistas Soviéticas (URSS) foi um marco para a grande estratégia russa. Ela passou por um período crítico nos anos 1990 e foi consolidada no século XXI.

Dessa forma, o foco deste trabalho é os governos dos presidentes Vladimir Putin (2001-2008) e Dimitry Medvedev (2009-2016). Embora o conceito de grande estratégia inclua questões de política doméstica, o enfoque recai mormente sobre a política externa e de segurança (PES) da Rússia. O motivo é que, mesmo que de suma importância, suas questões internas têm peso menor para a ONU do que sua PES. ${ }^{10}$ O que será observado na PES russa é sua relação com as instituições internacionais simbolizadas pela ONU (gerenciamento da ordem pelas grandes potências, equilíbrio de poder, soberania e não interferência e igualdade entre regiões). Para fazer isso, segue-se o receituário de Cornelia Navari (2014): serão analisados textos acadêmicos, discursos, legislação e o comportamento dos Estados e seus estadistas, focando nas justificativas das ações para detectar as posições quanto às instituições internacionais (e, por tabela, à ONU). Aspectos materiais e valorativos são considerados igualmente. Estes são enfatizados em questões normativas e aqueles na determinação dos aspectos geopolíticos e securitários em busca de desvendar a intenção da Rússia quanto à ordem internacional e à ONU.

A primeira parte do trabalho dedica-se a um panorama geral das grandes estratégias de Putin e Medvedev para estabelecer o contexto das ações e crenças da Rússia. Aspectos normativos serão tratados em seguida, dando conta da concepção de legitimidade que a Rússia tem na ordem internacional, seu ativismo global, relação com a sua região e com a ONU (e as instituições representadas por essa). Em um terceiro momento, são vistos os fundamentos securitários e geopolíticos da grande estratégia de Putin e Medvedev, tais como guerras e intervenções militares, participação e apoio militar em operações de paz da ONU, doutrina militar e mecanismos regionais de segurança. Essa parte servirá principalmente

9 Nota-se aqui mais uma afinidade do conceito de grande estratégia com a escola inglesa, a qual defende a utilização de métodos clássicos/históricos e não puramente positivistas para analises em RI (BULL, 1966; NAVARI, 2014).

10 Além disso, o desenho e a implementação da grande estratégia internamente têm sido mais conturbados; inclusive há quem questione a própria existência de uma grande estratégia russa por causa disso (e.g. MONAGHAN, 2013). 
para determinar o posicionamento russo com relação à instituição da balança de poder. Por fim, tecem-se conclusões a respeito do papel da ONU na grande estratégia russa e sobre a própria vitalidade das instituições que estão inseridas na organização.

\section{A grande estratégia da Rússia sob Putin e Medvedev}

Após o fim da União Soviética no início dos anos 1990, a Rússia atravessou uma década de declínio econômico, obsolescência de suas Forças Armadas e crise política. A ascensão de Vladimir Putin à presidência do país em 2000 veio mudar a situação. Putin procurou reerguer o país à condição de potência mundial, prestando especial atenção à segurança e ao desenvolvimento russos.

Se, na década de 1990, a grande estratégia da Rússia voltava-se a certo alinhamento com os Estados Unidos, Putin procurou limitar essa posição. A cooperação com Washington seria feita entre iguais e não em uma condição inferior. Porém, isso não impediu que houvesse um reconhecimento de que a Rússia estava debilitada e que precisaria de um grande esforço para manter sua condição de grande potência (MACFARLANE, 2009). Já no ano 2000, Moscou defendia um discurso de multipolaridade, democratização das relações internacionais e respeito ao direito internacional em oposição às tendências de unilateralismo e unipolaridade de Washington:

Há uma crescente tendência em direção ao estabelecimento de uma estrutura mundial unipolar com o domínio econômico e político dos Estados Unidos [...] A estratégia de ações unilaterais pode desestabilizar a situação internacional, provocar tensões e a corrida armamentista, agravar contradições interestatais, nacionais e conflitos religiosos [...] A Rússia há de procurar o estabelecimento de um sistema multipolar de relações internacionais que realmente reflita a diversidade do mundo moderno com sua grande variedade de interesses. Levar em conta interesses mútuos é a garantia de efetividade e confiabilidade de tal ordem mundial. A ordem mundial do século XXI deve ser baseada em mecanismos de resolução coletiva dos principais problemas, na prioridade do direito e em uma ampla democratização das relações internacionais (PUTIN, 2000, tradução própriai1 ${ }^{11}$.

11 No original: "There is a growing trend towards the establishment of a unipolar structure of the world with the economic and power domination of the United States [...] The strategy of unilateral actions can destabilize the international situation, provoke tensions and the arms race, aggravate interstate contradictions, national and 
Não só isso, mas questões de estabilização interna e de desenvolvimento socioeconômico também eram tratados no Conceito de Política Externa daquele ano (PUTIN, 2000). A Rússia enfrentava o separatismo checheno - cujo combate era fortemente criticado pelos EUA e demais potências ocidentais - além de ter de lidar com a grave situação econômica herdada da década de 1990. Situações essas que teriam de ser contornadas para que se atingisse novamente o status de potência mundial.

Com efeito, o aumento dos preços internacionais de hidrocarbonetos, aliado à marcada dependência energética da Europa para com a Rússia e às reformas econômicas domésticas realizadas por Putin, impulsionou o crescimento econômico russo no século XXI. Isso permitiu que política externa crítica à hegemonia estadunidense pudesse ser levada a cabo ao longo da presidência de Putin (MACFARLANE, 2009; OLDBERG, 2010; QUADROS; MACHADO, 2015).

Entretanto, ainda que houvesse críticas ao projeto neoconservador de George W. Bush nos EUA, os atentados terroristas de 11 de setembro de 2001 serviram para abrir as portas para uma maior cooperação bilateral. Washington e Moscou passaram a trabalhar conjuntamente no combate ao terrorismo (e, nesse quesito, Putin conseguiu apoio estadunidense no combate ao separatismo na Chechênia) e à proliferação nuclear. A cooperação não foi reduzida à esfera bilateral. Em 2002, criou-se um mecanismo de diálogo direto entre a Organização do Tratado do Atlântico Norte (OTAN) e a Rússia para facilitar a cooperação nesses quesitos.

Como resposta aos ataques terroristas em solo americano, os EUA e a OTAN invadiram o Afeganistão. Inicialmente a Rússia não se opôs à medida, considerada como legítima defesa. Todavia, ela chamou atenção para a crescente influência dos países ocidentais no antigo espaço soviético (Ásia Central e Europa Oriental), chamado de "exterior próximo".

Embora se considerasse, desde os anos 1990, que o "exterior próximo" fosse vital para a segurança russa e para seu status de grande potência, foi apenas a partir dos anos 2000 que medidas concretas foram tomadas para a manutenção da influência russa na região (OLIKER et al., 2015; QUADROS; MACHADO, 2015). A cooperação bilateral com países do leste europeu e centro-asiáticos foi intensificada, bem como diversos projetos de integração regional, econômica e securitária.

religious strife [...] Russia shall seek to achieve a multi-polar system of international relations that really reflects the diversity of the modem world with its great variety of interests. Taking into account mutual interests is the guarantee of effectiveness and reliability of such a world order. The world order of the XXI century must be based on mechanisms of collective resolution of key problems, on the priority of law and broad democratization of international relations." 
Nesse período se cria a Comunidade Econômica Eurasiana (EURASEC, sigla em inglês) e ganham novas dimensões a Comunidade de Estados Independentes (CEI), a Organização do Tratado de Segurança Coletiva (OTSC) e a Organização para Cooperação de Xangai (OCX) (OLDBERG, 2010). A última, especificamente, adquiriu um caráter de resposta clara ao neoconservadorismo vigente nos EUA ao, em parceria com a China, defender uma multipolaridade sem hierarquias e enfatizando princípios como o da soberania, integridade territorial e não interferência em assuntos domésticos (HEREJK RIBEIRO, 2015).

Percebia-se que havia uma disputa corrente por influência no "exterior próximo", sobretudo com a expansão da OTAN e da União Europeia (UE) no Leste Europeu. Em 2004, os antigos territórios soviéticos no Báltico, Estônia, Letônia e Lituânia, tornaram-se membros da aliança militar transatlântica. Além disso, as chamadas "revoluções coloridas" passaram a acontecer na vizinhança russa: em 2003, na Geórgia; 2004, na Ucrânia; e 2005, no Quirguistão. Processos endógenos ou não, Moscou percebeu-as como golpes de Estado organizados pelo Ocidente (KLEIN, 2015; MEARSHEIMER, 2014). Além disso, após o incidente de Andijan no Uzbequistão, os próprios países centro-asiáticos começaram a questionar a presença ocidental na região, vista como desestabilizadora ao promover mudanças de regimes em prol de democracias liberais de mercado (GOMES GUIMARÃES et al, 2010). A OCX e a Rússia em particular aproveitaram a ocasião para fortalecer sua presença na região. Moscou empreendeu esforços para trazer os Estados do antigo espaço soviético de volta à sua esfera de influência, criando mecanismos regionais de monitoramento eleitoral, resolução de conflitos e cooperação econômica e militar (OLDBERG, 2010). Ademais, a Rússia conseguiu fazer com o que o Uzbequistão entrasse na OTSC e revogasse a licença concedida aos EUA para usar uma base militar no país.

A investida ocidental na vizinhança russa também se fez presente no setor energético. UE e EUA elaboraram diversos planos de construção de gasodutos e oleodutos vindos do Cáucaso e da Ásia Central sem passar por território russo. A diversificação dos fornecedores de hidrocarbonetos para a Europa ia de encontro aos interesses russos. Foi nesse contexto que ocorreu a primeira interrupção do fornecimento de gás natural para a Ucrânia e, por consequência, para grande parte da UE. Moscou primava em manter o quase monopólio do fornecimento. Por isso, foram apresentados planos concorrentes que iriam diretamente do território russo para a UE sem atravessar países da Europa Oriental, diminuindo custos e 
incertezas, sejam dos dutos em uso, sejam dos planejados (PFEIFER CRUZ; LIMA MACHADO, 2012).

A chegada de Dmitry Medvedev à presidência em 2008 não trouxe grandes novidades à grande estratégia russa, mas afirmou-se, em seu Conceito de Política Externa, que o país já tinha retornado ao seu status de grande potência no sistema internacional (QUADROS; MACHADO, 2015). Esse retorno significou uma nova atitude na defesa dos interesses russos no exterior próximo, uma região onde a Rússia teria “privilégios” (OLIKER et al., 2015, p. 5). Ainda em 2008, a Rússia travou um breve conflito armado com a Geórgia a fim de proteger cidadãos e cidadãs russas nas províncias georgianas da Abcásia e Ossétia do Sul. Com a vitória russa e dos grupos separatistas, Moscou mostrou que havia um limite para a expansão da OTAN para o Leste Europeu e que daria a última palavra sobre projetos de infraestrutura energética na região (CALICH et al., 2013). ${ }^{12}$

As relações da Rússia com o Ocidente começaram a piorar com as sanções impostas por esses devido à guerra no Cáucaso e com o lançamento do projeto do escudo antimísseis dos EUA no Leste Europeu. Esse sistema antimísseis balísticos é tido por Moscou como um fator de desequilíbrio no sistema internacional pois compromete a paridade estratégica (armas nucleares) com os EUA: o escudo antimísseis poderia inviabilizar a capacidade de segundo ataque russa (PICCOLLI, 2012). Um fator agravante era de que se supunha que a revolução colorida na Ucrânia tivesse acontecido para que o escudo lá fosse instalado, i.e. às portas da Rússia (PFEIFER CRUZ; LIMA MACHADO, 2012).

Esse descontentamento no âmbito securitário também se refletiu no econômico. A crise econômica de 2007-2008 afetou severamente a economia russa no ano de 2009. Moscou culpou o modelo econômico financeiro unipolar do Ocidente pela crise (OLDBERG, 2010). Isso impeliu o país a concretizar parcerias com potências emergentes como Brasil, Índia e China, formando os BRICS em 2009 (com a posterior inclusão da África do Sul).

A eclosão da chamada "primavera árabe” tornou-se também um fator de piora das relações da Rússia com o Ocidente. A mudança de regime perpetrada com significativo apoio da OTAN na Líbia e em extrapolação do mandato do Conselho de Segurança da ONU colocou Moscou em uma posição defensiva no Oriente Médio. Quando medidas similares foram sugeridas para o caso sírio, Moscou colocou-se

12 A Geórgia vinha pleiteando a associação à OTAN e era parte dos projetos de gasodutos e oleodutos independentes da Rússia. 
firmemente contra. A Rússia enviou navios de guerra para o leste do Mediterrâneo em claro sinal de que não toleraria ataques ocidentais contra o regime aliado de Bashar al-Assad. ${ }^{13}$ Mas, para além da mera manutenção da esfera de influência no Oriente Médio, a atitude russa estava interessada em combater o extremismo na Síria e indiretamente na própria Rússia, afinal, diversos combatentes contrários a Assad eram separatistas chechenos (HILL, 2013). De fato, esse é um dos motivos que levaram Putin, novamente na presidência do país, a autorizar a realização de bombardeios contra posições do "Estado Islâmico" e de demais forças opositoras sírias no Oriente Médio em 2015.

Se a Rússia já tinha a percepção de que os EUA e a UE estavam promovendo mudanças de regime no Oriente Médio, ela só aumentou com a queda de Viktor Yanukovich do poder na Ucrânia em 2012. A "revolução de Maidan” foi vista por Moscou como um golpe de Estado sancionado por Washington e Bruxelas, contando com o apoio a grupos de extrema direita no país. Em reposta, a Rússia procurou treinar e armar grupos de resistência, inclusive separatistas, no leste ucraniano. Eclodiu assim uma guerra após a ocorrência de uma nova "revolução colorida", a qual procurava afastar Kiev da esfera de influência russa. ${ }^{14} \mathrm{O}$ conflito atingiu um novo patamar quando a Rússia anexou a península da Crimeia, que fazia parte da Ucrânia, após a população local, de maioria russa, ter votado em um referendo para se juntar à Federação Russa.

Em suma, a grande estratégia russa sob Putin e Medvedev visa à manutenção do status de grande potência do país e, para isso, é visto como necessária a garantia de sua esfera de influência no antigo espaço soviético (o exterior próximo). Nas palavras de Neil MacFarlane (2009, p. 99), “[a] política externa russa é, em resumo, um jogo de espera. Ela é desenhada para limitar maiores perdas e para sustentar ou promover condições que - no longo prazo - permitam que a Rússia ressurja como uma grande potência em um sistema internacional pluralista”. De fato, Elbridge Colby diz que:

A estratégia e a política externa russas atuais estão focadas na restauração do poder do país em sua área tradicional de influência ou domínio e na

13 Com efeito, Lucas Kerr, Pedro Brites e João Arthur Reis (2013) notam que “a presença da marinha russa no Mediterrâneo não teve caráter meramente simbólico, mas sim de dissuasão efetiva, ao demonstrar a possibilidade de escalada do conflito em caso de intervenção americana”.

14 Nessa mesma época a Rússia pretendia lançar a União Econômica Eurasiana (UEE), um estágio mais avançado da EURASEC, com a participação da Ucrânia, o que não ocorreu devido à queda de Yanukovich. A UEE foi criada em 2014 com Rússia, Cazaquistão, Belarus, Armênia e Quirguistão como membros fundadores. 
defesa da Rússia de desafios externos [...] a atual (e muito provavelmente também no futuro próximo) liderança na Rússia deseja recobrar algum grau da suserania que possuía antes do colapso do império soviético. Moscou vê a expansão da OTAN bem como o crescente papel da União Europeia em áreas as quais julga estarem dentro de sua esfera de influência pondo esse objetivo em perigo. (COLBY, 2016, p. 3, tradução própria' ${ }^{15}$ ).

Isso não significa que não houve aberturas para cooperação com o Ocidente. Elas existiram sob Putin e Medvedev, só que não foram aproveitadas. As relações entre ambos atingiram níveis baixíssimos e, ainda que haja tentativas de concertação para a resolução conjunta dos conflitos na Ucrânia e na Síria, não parece que elas vão melhorar rapidamente, especialmente após denúncias de que a Rússia teria interferido nas eleições presidenciais dos EUA em 2016. Isso impeliu a Rússia a fortalecer suas iniciativas de integração regional através da UEE e com a China. Além disso, buscou apoio das potências emergentes (Brasil, China, Índia e África do Sul, principalmente) para a defesa de suas posições críticas à ordem mundial liderada pelos EUA.

\section{Aspectos normativos da grande estratégia Russa}

Como visto na introdução, a ordem internacional baseia-se, por um lado, em questões do que é legítimo e justo e, por outro, em questões de distribuição de poder. Quanto às questões de justiça na ordem internacional, a Rússia de Putin e Medvedev estão satisfeitas com o estado atual: procuram preservá-lo e fazer com que as regras vigentes sejam válidas para todos, especialmente para o hegêmona, i.e. os Estados Unidos. No Conceito de Política Externa de 2000, Putin (2000, tradução própria ${ }^{16}$ ) afirmou que “a ordem mundial do século XXI deve ser baseada em mecanismos de resolução coletiva dos principais problemas, na prioridade do direito e em uma ampla democratização das relações internacionais”. O aspecto da democratização do sistema internacional deve ser entendido como uma crítica

15 No original: “Contemporary Russian strategy and foreign policy are focused on restoring the power of the nation in its traditional area of influence or dominion and defending Russia from external challenge [...] the current (and most likely for the near future) leadership in Russia wishes to regain some degree of the suzerainty it enjoyed before the collapse of the Soviet empire. Moscow sees NATO expansion as well as the growing role of the European Union into areas it judges as falling within its sphere of influence as jeopardizing this objective.”

16 No original: "The world order of the XXI century must be based on mechanisms of collective resolution of key problems, on the priority of law and broad democratization of international relations." 
à hegemonia estadunidense, particularmente em relação a ações unilaterais.

Sendo assim, a Rússia entende que os EUA (e em menor grau a UE) são agentes desestabilizadores do sistema ao promoverem mudanças de regime e minarem as instituições de soberania, não interferência e até mesmo a integridade territorial. A promoção da democracia liberal de mercado, defesa de conceitos como a "responsabilidade de proteger" (R2P)17 e apoio (ou mesmo estímulo e financiamento) a "revoluções coloridas" seriam comportamentos que desestabilizam o sistema e reforçam a unipolaridade americana (GOMES GUIMARÃES, 2016). Ao invés disso, a Rússia prefere "consistência e previsibilidade" além de "pragmatismo de benefícios mútuos” (PUTIN, 2000, tradução própria). Nas palavras do ministro das Relações Exteriores da Rússia, Sergei Lavrov:

A Rússia, que passou por um período no qual encorajava transformações artificiais no exterior, acredita firmemente na preferência em mudança evolucionária que deve ser feita de tal forma e em tal velocidade que correspondam às tradições das respectivas sociedades e a seus níveis de desenvolvimento (LAVROV, 2016, tradução própria'18).

Por consequência, há uma defesa veemente do direito internacional já estabelecido e oposição firme contra tentativas de alteração do mesmo como, por exemplo, a flexibilização do conceito de soberania através da R2P. Essas são tidas por Moscou como um subterfúgio para tornar legais atitudes ilícitas perante o direito internacional. Dessa forma, a Rússia procura fortalecer a instituição da soberania e não intervenção, basilar da ordem internacional e simbolizada pela ONU.

Tendo isso em mente, Moscou insiste que a ONU seja o principal centro de regulação das relações internacionais, opondo-se a qualquer tentativa de tornarem-na irrelevante (PUTIN, 2000). Putin criticou a invasão do Iraque por parte dos EUA em 2003 justamente por ignorar o Conselho de Segurança da ONU (CSNU) e Medvedev criticou a extrapolação do mandato conferido pelo órgão na mudança de regime na Líbia com apoio da OTAN em 2011 (MENDELSKI DE SOUZA; MACHADO, 2015; NIKITIN, 2012). Moscou, então, frisa a importância do gerenciamento conjunto da ordem internacional pelas grandes potências em

17 R2P é a responsabilidade de os Estados protegerem civis de violações de direitos humanos em massa e genocídio e, em caso de incapacidade ou relutância, essa responsabilidade ficaria a cargo da comunidade internacional.

18 No original: "Russia, which went through a period when it encouraged artificial transformations abroad, firmly believes in the preference of evolutionary change which should be made in such a form and at such a speed that would match the traditions of respective societies and their levels of development." 
oposição ao unilateralismo estadunidense. Assim, a Rússia defende a intensificação e consolidação do papel da ONU no mundo, não só por garantir que haja multilateralismo - mais entendido por Moscou como a concertação entre grandes potências do que igualdade plena de todos os países (MAKARYCHEV; MOROZOV, 2011) —, mas também porque é nesse fórum que possui mais influência e poder de decisão (com o veto). Há tanto uma defesa dos princípios da Carta da ONU que representam a instituição da soberania e não intervenção quanto a defesa da instituição do gerenciamento de grandes potências com a preservação do status dos membros permanentes do CSNU em eventuais reformas procedimentais ou da organização como um todo. A Rússia parece procurar fortalecer as instituições cristalizadas pela ONU, as quais, consequentemente, fortalecem a própria organização. Nas palavras de Neil MacFarlane:

Consciente de sua própria fraqueza e vulnerabilidade, os líderes russos apóiam [sic] fortemente um entendimento tradicional da soberania e jurisdição doméstica, resistindo à diluição desses conceitos em termos de direitos humanos e governança. Eles também buscam manter ou restaurar a posição das Nações Unidas como principal instituição multilateral global de segurança [...] (MACFARLANE, 2009, p. 98).

Justamente por reconhecer suas debilidades (herdadas em sua maioria da década de 1990), as ideias promovidas pela Rússia são de fortalecimento estatal, observância estrita da soberania e não interferência em assuntos internos. Essa promoção, no entanto, não é semelhante àquela dos EUA e da UE. A Rússia não procura exportar seu modelo como esses e lida com os regimes dos Estados tais como eles são (BABAYAN, 2015; BÖRZEL, 2015). Isso, contudo, não significa que aprove regimes ditatoriais ou que violem normas internacionais (especialmente a não proliferação nuclear), apenas procura se posicionar contra decisões unilaterais ou multilaterais em questões internas e ações prematuras (NIKITIN, 2012). A Rússia apenas busca servir de fator estabilizador e moderador do caos internacional (ENGSTRÖM, 2014). Ao não se envolver em questões internas de outros Estados, Moscou também se protege de interferências estrangeiras em sua jurisdição: a Rússia não confere legitimidade a grupos não estatais e trabalha para a centralização e desenvolvimento de seu próprio Estado. Essa seria mais uma instância em que Moscou procura reforçar a instituição da soberania e não interferência como base da ordem internacional representada na ONU. 
O desafio de compreensão dos aspectos normativos da grande estratégia russa está justamente em suas ações no exterior próximo, especialmente a guerra da Geórgia e o conflito na Ucrânia (incluindo a anexação da Crimeia), e do seu apoio a resoluções do CSNU que mencionam R2P, de caráter interventor em assuntos domésticos de outros Estados, dentre outros aspectos. Essas atitudes parecem ir de encontro aos próprios princípios defendidos pela Rússia de Medvedev e Putin. Como explicar que a Rússia tenha usado argumentos de R2P para o conflito na Geórgia e na Ucrânia? Por que Moscou não bloqueou iniciativas de intervenção no Sudão, Mali, Congo ou mesmo na Líbia? Há quem diga que a busca de interesses meramente geopolíticos faz com que a Rússia haja de maneira hipócrita, apenas para apontar o que percebe serem abusos do próprio Ocidente (e.g. ALLISON, 2013; ZIEGLER, 2016). No entanto, como nota Xymena Kurowska (2014), a visão russa compreende a responsabilidade como sendo do Estado e do CSNU e não da "comunidade internacional", o que seria muito difuso. Nos casos da Geórgia e da Ucrânia, portanto, era a responsabilidade do Estado russo de proteger seus cidadãos e suas cidadãs de violações de direitos humanos em massa naqueles países. Ou seja, a concepção russa de R2P, defendida na ONU e usada como justificativa para as intervenções na sua vizinhança, é uma de reforço à centralidade do Estado para a provisão de segurança (KUROWSKA, 2014). Por outro lado, as decisões do CSNU de intervenções na África e nas Américas (Haiti) não sofreram bloqueio por parte de Moscou porque há um entendimento de que o mundo multipolar implica também respeitar as decisões de cada uma das regiões (KUROWSKA, 2014). Logo, a Rússia não vetou a intervenção na Líbia (que tinha apoio da Liga Árabe e da União Africana), no Haiti (apoio da OEA e do Mercosul) e em outras ocasiões. Essa anuência a iniciativas regionais que aparentemente são contrárias à política externa russa espera que, em sua região - o exterior próximo - , as suas decisões também devem ser respeitadas pelos demais centros de poder mundiais.

Em suma, a Rússia procura que o sistema permaneça centrado na ONU e nos princípios já estabelecidos em sua Carta. Como lembra Oliver Stuenkel (2015), apesar de por vezes possuir uma retórica revisionista, a Rússia não procura subverter o sistema, mas, sim, adotar meios que façam o hegêmona (os EUA) e demais centros de poder jogarem pelas mesmas regras e normas básicas da ordem internacional liberal. Mudanças no sistema devem acontecer de forma evolucionária e não impostas. Assim a Rússia se manteria uma grande potência ao conservar sua capacidade de influenciar a política internacional, seja através do assento permanente no CSNU, seja no exterior próximo. Portanto, normativamente, a grande 
estratégia russa visa ao fortalecimento das instituições que se fazem presentes na ONU, quais sejam, o gerenciamento de grandes potências e a soberania e não intervenção. Ao procurar fortalecê-las, a Rússia acaba ressaltando o papel da ONU de conservação de seu status de grande potência e de preservação das normas de soberania e não intervenção. Além disso, a ONU seria uma garantidora de legitimidade e justiça através de decisões tomadas em concerto das grandes potências (Rússia inclusa) e do respeito à soberania e à não intervenção.

\section{Aspectos securitários e geopolíticos da grande estratégia Russa}

Das seções anteriores, fica claro que o foco geopolítico e securitário da Rússia está no seu entorno, o antigo espaço soviético, chamado de exterior próximo. Medvedev e Putin promoveram a integração regional nucleada em Moscou através da CEI, UEE e OTSC, além de cooperar securitariamente na Ásia através da OCX, com a participação da China. Vladimir Socor diz:

Moscou busca conquistar uma zona de responsabilidade para si na Eurásia, sob a bandeira da OTSC, seu mecanismo político, e suas forças coletivas. Nessa zona, a Rússia (agindo seja através da OTSC, de subgrupos regionais desta, ou unilateralmente) iniciaria e lideraria operações de paz, militares ou de "combate ao terrorismo" (SOCOR, 2010, tradução própria19 ${ }^{19}$ ênfase no original).

De fato, após esforços de Medvedev, a ONU reconheceu a OTSC como uma organização regional mantenedora da paz e provedora de segurança na Eurásia em 2010. O peso que a Rússia confere ao seu regionalismo e ao reconhecimento da ONU do mesmo indica que o país procura fortalecer a instituição internacional de igualdade entre as regiões ou representação regional, nos termos de Parrat (2014), uma vez que outras organizações regionais já possuíam esse reconhecimento. ${ }^{20}$

É através da CEI e da OTSC que a Rússia realiza suas operações de manutenção da paz (peacekeeping). Após as breves experiências na antiga Iugoslávia nos anos 1990, a participação de tropas russas em missões da própria ONU foi bastante limitada. Desde os anos 2000, a Rússia participou com, em média, 200 policiais,

19 No original: "Moscow seeks to carve out a zone of responsibility for itself in Eurasia, under the flag of the CSTO, its political mechanism, and its collective forces. In such a zone, Russia (acting either through the CSTO, the latter's regional subgroups, or unilaterally) would initiate and lead peacekeeping, military, or 'anti-terrorism' operations

20 Entre elas, a Organização dos Estados Americanos, a União Africana, a UE e a OTAN. 
observadores militares e civis por ano (MENDELSKI DE SOUZA; MACHADO, 2015). Em contraste, houve em média 10.000 soldados em operações de paz realizadas no exterior próximo (Geórgia, Moldávia/Transnístria, Armênia) de mandatos regionais ou bilaterais no mesmo período (IISS, 2013).

Segundo a percepção russa, as principais ameaças à segurança da região são a escalada de conflitos étnicos e religiosos que ponham em risco a coesão dos Estados e atividades que objetivam a mudança de regimes através da força (KLEIN, 2015). Em outras palavras, são riscos que vinculam ameaças externas e internas. Nesse contexto, a OTAN e seu processo de expansão para o Leste Europeu é tido como a principal ameaça à segurança russa, uma vez que Moscou vê na aliança a principal promotora de mudanças de regimes no mundo ("Primavera Árabe" e "revoluções coloridas") (COLBY, 2016). A principal forma de combater essa tendência seria através de maior cooperação e integração regionais, exatamente o que vem sendo feito por Moscou em diversos fóruns e organizações; porém, não se descarta o uso da força, como demonstra o caso ucraniano.

A expansão da OTAN (e UE) para o Leste Europeu, bem como sua atuação na desestabilização da Síria - tradicional aliada de Moscou e sede da única base naval russa no Mediterrâneo - , também é vista como uma ameaça porque procuraria impor uma camisa de força à Rússia, limitando sua projeção de força (OLIKER et al., 2015). Para o país, isso demonstra um desígnio ocidental de tentar subverter o equilíbrio de poder existente. As objeções russas, portanto, podem ser compreendidas como uma tentativa de fortalecer a instituição do balanço de poder entre as potências do globo.

Essa preocupação também se encontra na recepção russa aos projetos de defesa estadunidenses. Para Moscou, eles são uma tentativa de solapar a balança de poder nuclear. Em dezembro de 2001, Washington retirou-se do tratado antimísseis balísticos (Tratado ABM) para permitir o desenvolvimento de escudos antimísseis de todos os alcances. Sistemas de defesa antimísseis balísticos foram instalados não só em território estadunidense (Alasca e Califórnia), mas também na Europa e em breve no nordeste da Ásia. Além disso, a adoção do conceito operacional de Batalha Aeronaval, o qual prevê uso combinado de forças para acabar com a capacidade de processamento de informação do adversário em seu próprio território, põe em xeque as capacidades russas de resposta. Isso poderia levar a uma rápida escalada bélica, inclusive nuclear. Por fim, a implantação do sistema Global Strike por parte dos EUA também preocupa, pois daria a Washington o poder de atacar qualquer lugar no mundo em pouquíssimo tempo com mísseis 
convencionais e nucleares. Todos esses fatores juntos poderiam eliminar a capacidade de segundo ataque da Rússia e representam uma tentativa de domínio global por parte dos EUA (GOMES GUIMARÃES, 2016). A disposição por parte dos EUA e da OTAN, como um todo, de fazer uso da força fora dos canais legítimos, especialmente o CSNU, preocupa ainda mais Moscou. Por isso que Bruxelas e Washington são considerados as principais ameaças à segurança russa (COLBY, 2016). Assim, confirma-se a preocupação russa de que haveria uma tentativa de subverter o equilíbrio de poder da ordem internacional.

Mas a Rússia não fica parada. Reconhecendo que suas capacidades convencionais são inferiores, Moscou procurou atualizar sua política de uso de armas nucleares, além de investir na modernização de suas Forças Armadas. Segundo Colby (2016), o armamento atômico russo é visto como uma maneira de compensar essa fraqueza convencional vis-à-vis a OTAN e dissuadir os EUA. Com isso em mente, regularmente vêm sendo realizados exercícios militares no Leste Europeu que simulam o uso de armas nucleares por parte de Moscou. Também é bastante provável que a Rússia instale mísseis nucleares no enclave de Kaliningrado para contrabalançar a ativação do escudo europeu antimísseis (OSBORN, 2016). Dessa forma, Moscou procura assegurar a manutenção do equilíbrio de poder internacional. Colby afirma que:

\begin{abstract}
Moscou está procurando desenvolver e implantar uma força nuclear estratégica que seja capaz de demonstrar claramente a Washington que essa capacidade de primeiro ataque está fora de alcance e que tentativas dos EUA de uso da força para desarmar a Rússia de sua dissuasão estratégica resultariam em uma retaliação devastadora. Com esse fim, a Rússia vem equipando suas forças estratégicas com sistemas desenhados para prover alertas táticos e estratégicos melhores, funções de comando e controle redundantes e de contato direto [skip echelon], e novos mísseis MIRV projetados para penetrar as defesas adversárias (COLBY, 2016, p. 6, tradução própria²1).
\end{abstract}

Ademais, as Forças Armadas da Rússia estão desenvolvendo métodos de emprego limitado de armamento nuclear para dissuadir um ataque convencional de forças superiores (tais como a da OTAN) sem que haja uma escalada para guerra nuclear total ou uma guerra regional ampla (FEDEROV, 2010 apud COLBY, 2016).

21 No original: "Moscow is seeking to build and deploy a strategic nuclear force that is able to demonstrate clearly to Washington that such a first-strike capability is out of reach and that U.S. attempts to use force to disarm Russia of its strategic deterrent would result in devastating retaliation. To this end, Russia has been outfitting its strategic forces with systems designed to provide better tactical and strategic warning, redundant and skip echelon command and control functions, and new MIRVed missiles designed to penetrate adversary defenses.” 
Essa estratégia vem sendo chamada de "escalar para desescalar", sugerindo que serviria para interromper a ação militar de forças convencionais através da ameaça ou mesmo do uso de armas nucleares sem que haja uma maior conflagração. Margarete Klein (2015) também chama atenção para o fato de a Rússia também estar interessada em adquirir capacidades Global Strike tal como os EUA, i.e. possuir meios de dissuasão não nuclear (mas que permita o emprego de bombas atômicas).

Como as ações russas mostram, há um interesse do país em manter o equilíbrio de poder vigente. A percepção da Rússia é de que os EUA e a OTAN estão tentando erodir essa instituição, vital para a manutenção da ordem internacional. A ideia é a de que, se a balança de poder for desfeita, haveria um domínio dos EUA e da OTAN - o que Makarychev e Morozov (2011) chamam de "unilateralismo coletivo" - em detrimento da Rússia e da estabilidade da ordem internacional como um todo. As tentativas russas de manter a paridade nuclear bem como um equilíbrio geopolítico (assegurando seu predomínio no exterior próximo) podem ser vistas, então, como um fortalecimento da instituição da balança de poder e da própria ONU enquanto fórum para resolução de disputas e concertação entre as potências. Por outro lado, isso não significa um maior empoderamento da ONU para tratar de matérias muito sensíveis à sua segurança. Por exemplo, em março de 2017, houve uma importante rodada de negociações para o banimento de armas nucleares, as quais foram boicotadas pela Rússia (da mesma forma que EUA, China, França, Reino Unido, Alemanha, Japão, Austrália e as Coreias não se fizeram presentes) (CHANDRAN, 2017).

\section{Conclusões}

Hedley Bull (2002, p. 237-259) afirma que as grandes potências contribuem para a ordem mundial de duas formas principais: administrando os relacionamentos entre si e explorando a sua preponderância para centralizar os assuntos do conjunto da sociedade internacional. Quanto ao primeiro ponto, o autor nota mais especificamente que as potências agem de acordo com os interesses da ordem quando preservam o equilíbrio de poder, evitam e controlam crises no seu relacionamento recíproco, limitam ou controlam guerras entre si. Quanto ao segundo, a ordem seria garantida através da ação conjunta em um condomínio das grandes potências, com o respeito mútuo às suas esferas de influência, interesse e responsabilidade e à exploração unilateral da preponderância em suas regiões 
(com ou sem coerção). Em contraste, os Estados, grandes potências ou não, também podem agir de forma a perturbar a ordem internacional estabelecida ao procurar destruir o equilíbrio de poder em vez de preservá-lo, fomentar crises ao invés de controlá-las e ao não conter a escalada da guerra, i.e. ao não limitar os conflitos armados. De acordo com isso e com a pesquisa realizada neste trabalho, fica evidente que a Rússia é uma grande potência que busca contribuir para a estabilidade da ordem mundial. Mostrou-se que ela está interessada na manutenção do statu quo, preferindo que as mudanças ocorram de forma evolucionária a que elas sejam promovidas por um país ou grupo de países. Por causa disso, há a firme defesa da soberania nacional e não interferência em assuntos domésticos no plano internacional. Há um foco acentuado da PES russa para a sua região, tanto normativamente, ao exprimir a vontade de que suas decisões valham para o exterior próximo, sem interferência estrangeira (EUA e UE), quanto securitária e geopoliticamente, ao reforçar o papel da CEI, OTSC e OCX para a manutenção da paz e estabilidade em seu entorno. Em adição a isso, a Rússia procura conservar o estado atual do sistema internacional ao tentar impedir que Washington rompa o equilíbrio estratégico que há entre ambos.

Pode-se observar que a Rússia procura fortalecer algumas das mais importantes instituições cristalizadas na ONU e vitais para a sustentação da ordem internacional, quais sejam, a soberania e não intervenção, o gerenciamento de grandes potências, a balança de poder e a igualdade entre regiões (ou representação regional). Nesse sentido, a ONU seria praticamente um fim em si mesmo na grande estratégia russa ao promover o multilateralismo (em oposição ao unilateralismo estadunidense) e a concertação entre as regiões do globo, além de garantir o cumprimento do direito internacional, outra importante instituição internacional. È importante ressaltar que a Rússia não entende o multilateralismo como uma igualdade plena entre todos os países na hora de tomar decisões. Ela parece usar o termo como uma igualdade entre regiões, cada uma encabeçada por uma grande potência, que devem agir em concerto. Nesse sentido, Moscou parece de fato usar a representação regional como um meio-termo entre a legitimidade/justiça e poder.

Destarte, a ONU é vital à grande estratégia russa, pois asseguraria o status de grande potência da Rússia, seja através do poder de veto, seja garantindo a concertação entre as regiões. Além disso, o país vê na organização um meio de vincular os EUA às mesmas regras e instituições a que os demais países estão vinculados. De fato, a organização interessa à grande estratégia russa na medida em que conserva as instituições nela presentes (soberania e não intervenção, 
balança de poder, gerenciamento das grandes potências, direito internacional) e abre espaço para a igualdade entre regiões/representação regional.

Portanto, conservação parece ser a palavra-chave da grande estratégia russa, que busca, a todo custo, manter a condição de grande potência do país e a estabilidade da ordem internacional. Mudanças devem ser cautelosas, sem serem impostas por um único país ou grupo de países, senão haveria o risco da instauração do caos e da perda de poder e influência do país. Da mesma forma, o país não está preocupado em prescrever determinada forma de organização política (ao contrário de EUA e UE que buscam exportar democracia), algo que é tido como desestabilizador. Assim, a ONU seria o cerne da ordem internacional na grande estratégia russa, justamente por cimentar as instituições que garantem a estabilidade da ordem, tal como se visava no momento de sua criação em 1945.

\section{Referências}

ALLISON, R. Russia, the West, and military intervention. Oxford: Oxford University Press, 2013.

BABAYAN, N. The return of the empire? Russia's counteraction to transatlantic democracy promotion in its near abroad. Democratization, v. 22, n. 3, 16 abr. 2015, p. 438-458, BÖRZEL, T. A. The noble west and the dirty rest? Western democracy promoters and illiberal regional powers. Democratization, v. 22, n. 3, 16 abr. 2015, p. 519-535,

BRZEZINSKI, Z. Strategic vision: America and the crisis of global power. New York: Basic Books, 2012.

BULL, H. International theory: the case for a classical approach. World Politics, v. 18, n. 3, abr. 1966, p. 361-377.

BULL, H. A sociedade anárquica: um estudo da ordem política mundial. Brasília: Editora Universidade de Brasília, 2002.

BUZAN, B. An introduction to the English School of International Relations: the societal approach. Cambridge: Polity Press, 2014.

CALICH, A. P. de M. et al. Política externa e de segurança da Rússia. In: MARTINS, J. M. Q. (Org.). Relações Internacionais Contemporâneas 2012/2: estudos de caso em política externa e de segurança. Porto Alegre: ISAPE, Série Cadernos ISAPE, 2013. p. $48-71$.

CARMONA, R. The return of geopolitics: the ascension of the BRICS. Austral: Brazilian Journal of Strategy and International Relations, v. 3, n. 6, jul. 2014, p. 37-72. 
CEPIK, M. Segurança Internacional: da Ordem Internacional aos desafios para a América do Sul e para a CELAC. In: BONILLA, A.; ÁLVAREZ (Org.). Desafíos estratégicos del regionalismo contemporâneo: CELAC e Iberoamérica. San José: FLACSO, 2014. p. 307-324.

CEPIK, M.; MACHADO, F. O comando do espaço na grande estratégia chinesa: implicações para a ordem internacional contemporânea. Carta Internacional, v. 6, n. 2, jul. 2011, p. $112-131$

CHANDRAN, N. Denuclearization a pipe dream? UN holds talks to ban nukes, but major powers don't show up. CNBC, [S.1.], 27 mar. 2017. Disponível em: < http://cnb.cx/2nr3PkO > . Acesso em: 1 abr. 2017.

COLBY, E. Russia's evolving nuclear doctrine and its implications. Paris: Fondation pour la Recherche Stratégique, 2016.

DUNN, E. C.; BOBICK, M. S. The empire strikes back: War without war and occupation without occupation in the Russian sphere of influence. American Ethnologist, v. 41, n. 3, ago. 2014, p. 405-413.

DUNNE, T. The English School. In: GOODIN, R. E. (Org.). The Oxford Handbook of Political Science. Oxford: Oxford University Press, 2013. p. 1-22. Oxford Handbooks Online. ENGSTRÖM, M. Contemporary Russian Messianism and New Russian Foreign Policy. Contemporary Security Policy, v. 35, n. 3, 2 set. 2014, p. 356-379.

GOMES GUIMARÃES, Bruno. O papel da ONU na grande estratégia dos Estados Unidos: um estudo da política externa e de segurança dos governos Bush (2001-2008) e Obama (2009-2016). In: IX ENCONTRO NACIONAL DA ASSOCIAÇÃO BRASILEIRA DE ESTUDOS DE DEFESA (ENABED), 2016, Florianópolis. Anais eletrônicos. Florianópolis: ABED, 2016.

GOMES GUIMARÃES, Bruno et al. GOMES GUIMARÃES, B. et al. North Atlantic Council: the question of Central Asia. UFRGSMUN: Study Guides, Porto Alegre, nov. 2010.

HEREJK RIBEIRO, Erik. A expansão da Organização para a Cooperação de Xangai (OCX): uma coalizão anti-hegemônica? In: SEMINÁRIO INTERNACIONAL DE CIÊNCIA POLÍTICA, I, 2015, Porto Alegre. Anais. Porto Alegre: [s.n.], 2015.

HILL, F. The real reason Putin supports Assad. Foreign Affairs, 25 mar. 2013. Disponível em: < http://www.foreignaffairs.com/articles/139079/fiona-hill/the-real-reason-putinsupports-assad > . Acesso em: 23 set. 2016.

IISS. The Military Balance 2013. London: IISS, 2013.

KAGAN, R. Backing into World War III. Foreign Policy, [S.1.], 6 fev. 2017. Disponível em: < http://foreignpolicy.com/2017/02/06/backing-into-world-war-iii-russia-chinatrump-obama/ > . Acesso em: 1 abr. 2017. 
KERR DE OLIVEIRA, L.; BRITES, P.; REIS, J. A. da S. A guerra proxy na Síria e as disputas estratégicas russo-estadunidenses no Oriente Médio. Mundorama, 20 set. 2013. Disponível em: < http://www.mundorama.net/2013/09/20/a-guerra-proxyna-siria-e-as-disputas-estrategicas-russo-estadunidenses-no-oriente-medio-por-lucaskerr-de-oliveira-pedro-vinicius-pereira-brites-e-joao-arthur-da-silva-reis/ > . Acesso em: 20 set. 2016.

KHANNA, P. The Second World: how emerging powers are redefining global competition in the Twenty-First Century. London: Penguin Books, 2008.

KISSINGER, H. The European balance-of-power system and its end. World Order. 1. ed. New York: Penguin Books, 2014. p. 49-95.

KLEIN, M. Russia's new military doctrine: NATO, the United States and the "Colour Revolutions”. SWP Comments, v. 9, fev. 2015, p. 1-4

KORNEGAY, F. A. Laying the BRICS of a new global order: a conceptual scenario. In: KORNEGAY, F. A.; BOHLER-MÜLLER, N. (Org.). Laying the BRICS of a new global order: from Yekaterinburg 2009 to eThekwini 2013. Pretoria: Africa Institute of South Africa, 2013. p. 1-32.

KRASNER, S. D. An orienting principle for foreign policy. Policy Review, [S.1.], 1 out. 2010. Disponível em: < http://www.hoover.org/research/orienting-principle-foreign-policy > . Acesso em: 12 jun. 2016.

KUROWSKA, X. Multipolarity as resistance to liberal norms: Russia's position on responsibility to protect. Conflict, Security \& Development, v. 14, n. 4, 8 ago. 2014, p. 489-508,

LAVROV, S. Russia's foreign policy in a historical perspective. Russia in Global Affairs, 30 mar. 2016. Disponível em: < http://eng.globalaffairs.ru/number/Russias-ForeignPolicy-in-a-Historical-Perspective-18067 > . Acesso em: 24 set. 2016.

MACFARLANE, N. O "R" dos Brics: a Rússia é uma potência emergente? In: HURRELL, A. et al. (Org.). Os Brics e a ordem global. Rio de Janeiro: FGV Editora, FGV de bolso, Série Entenda o mundo, 2009. p. 75-99..

MAKARYCHEV, A.; MOROZOV, V. Multilateralism, multipolarity, and beyond: a menu of Russia’s policy strategies. Global Governance, v. 17, 2011, p. 353-373.

MARTEL, W. C. Grand strategy in theory and practice: the need for an effective American foreign policy. New York: Cambridge University Press, 2015.

MARTINS, J. M. Q. (Org.). Relações Internacionais Contemporâneas 2012/2: estudos de caso em política externa e de segurança. Porto Alegre: ISAPE, 2013.

MEARSHEIMER, J. J. Why the Ukraine crisis is the West's fault. Foreign Affairs, [S.1.], Set./ Out. 2014. Disponível em: < http://www.foreignaffairs.com/articles/141769/john-jmearsheimer/why-the-ukraine-crisis-is-the-wests-fault > . Acesso em: 17 jun. 2016. 
MENDELSKI DE SOUZA, B.; MACHADO, L. A política externa e a atuação russa no Conselho de Segurança das Nações Unidas de 1991 a 2014. Revista de Geopolítica, v. 6, n. 1, jun. 2015, p. 46-64

MONAGHAN, A. Putin's Russia: shaping a "grand strategy"? International Affairs, v. 89, n. 5, set. 2013, p. 1221-1236.

NAVARI, C. English School methodology. In: NAVARI, C.; GREEN, D. M. (Eds.). Guide to the English school in international studies. West Sussex: Wiley, 2014. p. 205-221.

NIKITIN, A. Russia as a permanent member of the UN Security Council. Berlin: FriedrichEbert-Stiftung, Global Policy and Development, 2012.

NYE, J. S. The Twenty-First Century will not be a "post-American" world. International Studies Quarterly, v. 56, n. 1, mar. 2012, p. 215-217

OLDBERG, I. Aims and means in Russian foreign policy. In: KANET, R. E. (Ed.). Russian foreign policy in the 21st century. Basingstoke: Palgrave Macmillan, 2010. p. 11-29.

OLIKER, O. et al. Russian foreign policy in historical and current context: a reassessment. Santa Monica, CA: RAND Corporation, 2015.

OSBORN, A. Russia seen putting new nuclear-capable missiles along NATO border by 2019. Reuters, [S.1.], 23 jun. 2016. Disponível em: < http://reut.rs/28QOvJK > . Acesso em: 23 set. 2016.

PARRAT, C. F. International organization in international society: UN reform from an English School perspective. Journal of International Organizations Studies, v. 5, n. 2, 2014, p. 7-21.

PFEIFER CRUZ, C.; LIMA MACHADO, I. B. Ucrânia: conjuntura energética e securitária as políticas energéticas e securitárias ucranianas no âmbito da política multivetorial de balanceamento. In: SEMINÁRIO BRASILEIRO DE ESTUDOS ESTRATÉGICOS INTERNACIONAIS (SEBREEI), I, 2012, Porto Alegre. Anais. Porto Alegre: [s.n.], 2012.

PICCOLLI, L. Europa enquanto condicionante da política externa e de segurança da Rússia: o papel da defesa antimíssil. Dissertação de mestrado em Estudos Estratégicos Internacionais. Porto Alegre: UFRGS, 2012. Disponível em: < http://hdl.handle. net/10183/70019 > . Acesso em: 16 jun. 2016.

PORTER, P. Sharing power? Prospects for a U.S. concert-balance strategy. Carlisle: U.S. Army War College Press, 2013.

PUTIN, V. Foreign policy concept of the Russian Federation. Ministry of Foreign Affairs of the Russian Federation, 2000. Disponível em: < https://fas.org/nuke/guide/russia/ doctrine/econcept.htm > . Acesso em: 20 set. 2017.

QUADROS, M. P. dos R.; MACHADO, L. A Rússia e o Exterior Próximo: potencialidades e entraves para um projeto de grande potência. Brazilian Journal of International Relations, v. 4, n. 3, set./dez. 2015, p. 582-607. 
ROTMANN, P.; KURTZ, G.; BROCKMEIER, S. Major powers and the contested evolution of a responsibility to protect. Conflict, Security \& Development, v. 14, n. 4, 2014, p. 355-377.

SCHOUENBORG, L. The English School and institutions: British institutionalists? In: NAVARI, C.; GREEN, D. M. (Eds.). Guide to the English School in International Studies. West Sussex: Wiley, 2014. p. 77-89.

SOCOR, Vladimir. The UN accepts CSTO as a regional security organization. Eurasia Daily Monitor, v. 7, n. 54, 19 mar. 2010. Disponível em: < http://www.jamestown.org/ single/?tx_ttnews \%5Btt_news $\% 5 \mathrm{D}=36177 \&$ no_cache $=1 \#$.V-bfyfkrKUk > . Acesso em: 24 set. 2016.

STUENKEL, O. The BRICS and the future of global order. Lanham: Lexington Books, 2015. TEIXEIRA, C. G. P.; NASSER, R. M. A Doutrina Bush e a construção de uma ordem liberal? In: CEPIK, M. (Org.). Segurança internacional: práticas, tendências e conceitos. São Paulo: Hucitec, 2010. p. 172-196. Relações internacionais.

TSYGANKOV, A. P. Assessing Cultural and Regime-Based Explanations of Russia’s Foreign Policy. "Authoritarian at Heart and Expansionist by Habit"? Europe-Asia Studies, v. 64 , n. 4 , jun. 2012, p. 695-713.

United Nations. General Assembly. A/70/331/Add.1. Implementation of General Assembly resolutions 55/235 and 55/236. New York, 28 dez. 2015.

United Nations. Secretariat. ST/ADM/SER.B/910. Assessment of Member States' contributions to the United Nations regular budget for the year 2015. New York, 29 dez. 2014.

VALKOV, V. Expansionism: the core of Russia's foreign policy. New Eastern Europe, [S.l.], 12 ago. 2014. Disponível em: < http://www.neweasterneurope.eu/interviews/1292expansionism-the-core-of-rus-\% 20sia-s-foreign-policy > . Acesso em: 1 abr. 2017. VIZENTINI, P. F. O descompasso entre as nações. Rio de Janeiro: Editora Record, 2004. WALTZ, K. N. Globalization and governance. PS: Political Science and Politics, v. 32, n. 4, dez. 1999, p. 693-700.

ZIEGLER, C. E. Russia on the rebound: using and misusing the Responsibility to Protect. International Relations, v. 30, n. 3, 1 set. 2016, p. 346-361. 


\section{Hegemonia compartilhada e organizações internacionais: a proposta trilateralista dos anos de $1970^{1}$}

\section{Shared hegemony and international organizations: the trilateralist proposal of the 1970's}

DOI: $10.21530 /$ ci.v12n2.2017.627

Rejane Hoeveler ${ }^{2}$

\section{Resumo}

No início dos anos de 1970, a criação da Trilateral Commission, composta por intelectuais, empresários e políticos de Estados Unidos, Japão e Europa Ocidental, trazia uma nova perspectiva estratégica em um mundo atribulado por disputas comerciais e políticas dentro do bloco capitalista. Inspirada e formulada por intelectuais como Zbigniew Brzezinski, ela teve como um de seus temas centrais a reformulação das instituições internacionais, vistas por eles como conturbadas por uma confrontação cada vez maior por parte de coalizões de países do então chamado Terceiro Mundo. A Trilateral Commission reunia algumas figuras-chave de instituições como o Fundo Monetário Internacional e o Banco Mundial, e suas propostas para a reformulação dessas e de outras instituições vinham no sentido de "despolitizá-las", criando mecanismos permanentes de prevenção de conflitos internacionais. Para estrategistas como Brzezinski, essa era uma forma de recompor a hegemonia americana que, confrontada pela "síndrome do Vietnã" e com a crise do petróleo, parecia agora aceitar a ideia de uma "hegemonia compartilhada”. O propósito do artigo é mostrar como as propostas trilateralistas para o funcionamento das organizações internacionais foram uma das principais alternativas estratégicas desenvolvidas naquele contexto histórico.

Palavras-chave: Organizações internacionais; Comissão Trilateral; Hegemonia; teoria neogramsciana

\footnotetext{
Abstract

In the early 1970s, the creation of the Trilateral Commission, made up of intellectuals, entrepreneurs, and politicians from the United States, Japan, and Western Europe, brought a new strategic perspective into a world beset by trade and political disputes within the capitalist

1 Este artigo é parte de pesquisa financiada pela CAPES.

2 Departamento de História da Universidade Federal Fluminense, Niterói/RJ, Brasil. E-mail: rejanecarol@gmail.com Artigo submetido em 08/02/2017 e aprovado em 08/05/2017.
} 
bloc. Inspired and formulated by intellectuals such as Zbigniew Brzezinski, it had as one of its central themes the reformulation of international institutions, which they saw as being disturbed by a growing confrontation by the coalitions of countries of the Third World. The Trilateral Commission brought together key figures from institutions such as the International Monetary Fund and the World Bank, and its proposals for the reformulation of these and other institutions came in the direction of "depoliticizing” it, by creating mechanisms for a permanent prevention of international conflicts. For strategists like Brzezinski, this was a way of re-establishing american hegemony which, faced with the "Vietnam syndrome" and the oil crisis, now seemed to accept the idea of "shared hegemony." The purpose of the article is to demonstrate the trilateralist proposals for the functioning of international organizations as one of the most important strategic alternatives developed in that historical context.

Keywords: International organizations; Trilateral Commission; Hegemony; neogramscian theory

“A prevenção de conflito é melhor que a resolução de conflito; e as aspirações a um sistema internacional devem ir além de meramente lidar com problemas futuros para moldar esses eventos.” (COOPER, KAISER \& KOSAKA, 1977, p. 200)

A Trilateral Commission, criada em 1973, foi fruto de iniciativa de estrategistas norte-americanos num contexto em que a hegemonia global dos Estados Unidos parecia estar fundamentalmente em xeque. A crise econômica mundial, com alta inflação combinada à estagnação, os “choques” do petróleo e a onda mobilizatória - que varreu o mundo em 1968 - somaram-se, no caso americano, a uma forte oposição à escalada da Guerra do Vietnã. “Trilateral” foi o nome escolhido por seus criadores por se tratar de uma proposta de aliança entre as três regiões do mundo consideradas industriais e democráticas (ou "sociedades trilaterais”, no linguajar da comissão): Estados Unidos, Japão e Europa Ocidental. A ideia básica da comissão era que deveria haver uma firme e consistente ação conjunta dessas três regiões, mas a comissão se definia como uma iniciativa de cidadãos individuais, e não de governos ou empresas - embora a presença de burocratas de Estado, bem como de empresários, fosse bastante grande na comissão, juntamente com a dos intelectuais, em especial economistas e teóricos de relações internacionais ${ }^{3}$.

Procuraremos mostrar neste artigo que o viés institucionalista e liberal da Trilateral Commission, presente no pensamento dos intelectuais ligados a ela, em

3 Os dois grandes impulsionadores da comissão foram David Rockefeller, magnata americano do petróleo e das finanças, e o sovietólogo Zbigniew Brzezinski, estrategista, à época, já bem conhecido nos círculos diplomáticos dos Estados Unidos. 
especial economistas e teóricos de relações internacionais, marcou profundamente suas propostas de reforma das organizações internacionais. Também demonstraremos que os chamados trilateralistas não estavam preocupados com mudanças de curto prazo, mas sim com formatos institucionais de longa duração, que deveriam atender à necessidade de viabilizar as negociações internacionais de maneira a “despolitizar” os conflitos de forma relativamente permanente. Demonstraremos que tais propostas tiveram grande relevância entre importantes empresários, políticos e burocratas de Estado da época, e que, por isso, a proposta trilateralista foi a mais elaborada alternativa estratégica colocada naquele contexto de crise de hegemonia internacional. Pretendemos demonstrar essa relevância através da análise dos atores políticos envolvidos nesse projeto, bem como de sua influência direta e indireta em organismos como o Banco Mundial e a Agência Internacional de Energia. Nosso objetivo não será provar a influência direta da comissão em casos específicos de reformas de organizações internacionais, embora façamos referências a alguns deles, mas sim demonstrar a relação entre o pensamento e a ação política que tornaram possível o surgimento da proposta trilateralista.

Embora a comissão tenha ficado mais famosa por seu relatório sobre a crise das democracias (HUNTINGTON, CROZIER \& WATANUKI, 1975), em seu bojo foram formuladas propostas relativas a numerosos temas, com destaque para a crise do petróleo, a crise do sistema monetário internacional e a reforma das instituições internacionais - esta última, pouquíssimo visitada na literatura especializada, com raras exceções (BONHOMME, 2014) . Empenhados em uma reavaliação geral da diplomacia americana dos anos de 1950 e 1960, os intelectuais ligados à comissão, como Zbigniew Brzezinski, procurariam desenvolver um quadro compreensivo e normativo para a política externa dos Estados Unidos (BRZEZINSKI, 1971). Embora o tema das organizações internacionais tenha sido um dos mais discutidos no âmbito da Trilateral Commission desde seu início, em 1973, os primeiros relatórios sistemáticos sobre o assunto seriam publicados apenas a partir de 1976 - ano no qual as eleições nos Estados Unidos consagrariam o democrata “Jimmy” Carter na presidência, ele próprio um membro da Trilateral Commission (SKLAR, 1980; GILL, 1990).

Este artigo, portanto, pretende tratar do tema das organizações internacionais, tão caro entre os estudiosos de relações internacionais, a partir de uma análise

4 O último estudo relevante sobre a Trilateral Commission foi o trabalho de Stephen Gill (1990), onde a questão da reforma das instituições internacionais não é pormenorizada. 
histórica do chamado trilateralismo, não somente apresentando detalhadamente os principais aspectos de suas propostas para o formato das instituições internacionais, como também demonstrando a íntima relação dessas com determinadas teorias bastante influentes no campo das relações internacionais - como, por exemplo, o conceito de "interdependência complexa" de Joseph Nye e Robert Keohane. Nesse sentido, o artigo procura se inserir no frutífero reconhecido diálogo existente entre o campo da história e o das relações internacionais. Numa época em que relevantes organizações internacionais como a União Européia parecem quebrar, e em que se procura entender uma nova crise de hegemonia internacional, acreditamos ser útil revisitar as propostas e experiências de reforma de organizações internacionais dos anos de 1970.

\section{Organizações internacionais e crise de hegemonia: uma visão a partir da teoria crítica}

Muito embora a criação da Organização das Nações Unidas (ONU) e do complexo de instituições internacionais que conformou o chamado sistema de Bretton-Woods já tivesse despertado o interesse no estudo acerca das organizações internacionais, é somente na década de 1960, mas principalmente na de 1970, que proliferam os estudos nesse campo. Segundo Herz e Hoffman, ocorre uma separação analítica, na década de 1960, entre o debate acerca dos mecanismos de estabilização do sistema internacional e os estudos sobre o papel das organizações internacionais, a fim de desvendar a função específica das Organizações Intergovernamentais Internacionais (OIGs) (HERZ; HOFFMAN, 2004, p. 45). Nessa geração de estudos, diversos temas teriam sido tratados, como segurança nuclear, "assistência aos processos de descolonização" e "ajuda ao desenvolvimento". Esses estudos, em geral, eram críticos da chamada teoria realista, que considerava o Estado como único e indivisível ator nas relações internacionais.

Na década seguinte, dois dos maiores focos dos estudos sobre organizações internacionais foram as relações Norte-Sul e os problemas do meio ambiente. Segundo Herz e Hoffman, uma orientação marcante nessa bibliografia dos anos de 1970 é a relação entre a constituição do sistema internacional e o papel das organizações internacionais. Os fóruns para a formação de coalizões e as formas de coordenação de políticas transgovernamentais seriam algumas das funções das organizações internacionais abordadas nesse contexto (HERZ; HOFFMAN, 2004, p. 46). É desse período o conhecido trabalho de Robert Cox e de Harold 
Jacobson sobre oito agências especializadas da ONU (COX; JACOBSON, 1973). O papel das organizações internacionais após a Segunda Guerra Mundial, segundo os trabalhos posteriores de Cox, teria sido fundamental para a universalização das normas compatíveis com o hegemon da pax americanna.

A ideia de hegemon e de hegemonia para o sistema internacional foi desenvolvida por diversos autores inspirados nos escritos do filósofo sardo Antonio Gramsci (1891-1937). Em seu O longo século XX, por exemplo, Giovanni Arrighi constrói um grande painel da história do capitalismo entre os séculos XVI e XX, buscando demonstrar que tal trajetória histórica teria sido marcada por aquilo que chama de "ciclos sistêmicos" de acumulação mundial, onde um país assumiu a posição de centro hegemônico do sistema internacional. O sociólogo italiano observa que alguns dos fenômenos observados a partir dos anos de 1970 - que ele e autores como Immanuel Wallerstein (2004) consideram sintomas do fim da hegemonia dos EUA, como a financeirização e a constituição de uma nova divisão internacional do trabalho - são características encontráveis em situações anteriores que marcaram o fim das hegemonias do sistema internacional do capitalismo histórico (ARRIGHI, 1996).

Por sua vez, a análise de Cox sobre as organizações internacionais se revela bastante instigante, pois o autor entende que essas desempenham papéis fundamentais em uma ordem mundial hegemônica, como: "corporificar as regras que facilitam a expansão das ordens mundiais hegemônicas"; "legitimar ideologicamente as normas da ordem mundial”; "cooptar as elites dos países periféricos"; e "absorver ideias contra-hegemônicas” (COX, 2007). Nas palavras de Cox,

As instituições internacionais corporificam regras que facilitam a expansão das forças econômicas e sociais dominantes, mas permitem simultaneamente aos interesses subordinados fazerem ajustes com um mínimo de desgaste. (COX, 2007, p. 119)

O sistema hegemônico construído no pós-Segunda Guerra Mundial, que incluiu a formatação de todo um sistema de organizações intergovernamentais, parecia ter chegado a um esgotamento. As organizações internacionais moldadas no período da chamada pax americanna não poderiam passar incólumes por essa crise de hegemonia, marcada, entre outros fatos, pelo surgimento de diversos tipos de coalizões de países do Terceiro Mundo5.

5 Estamos utilizando a expressão Terceiro Mundo de maneira meramente descritiva. 
Cox localiza entre fins dos anos de 1960 e início da década de 1970 o fim daquilo que ele denominou "Estado neoliberal" da Pax Americanna, constituído após o fim da Segunda Guerra Mundial'b, uma forma de Estado que tinha determinados papéis no bloco de forças sociais dentro dos Estados nacionais. O autor considera o contexto de fins dos anos de 1960 e início dos anos de 1970 como fundamentalmente não hegemônico, e localiza nesse período um ponto de virada. A crise da hegemonia americana teria provocado a necessidade de uma nova e modificada estrutura institucional. Essa crise, segundo Cox, teria gerado a necessidade da construção de um novo consenso hegemônico, que teria que refletir necessariamente não apenas o novo peso econômico e político da Alemanha Ocidental e do Japão, bem como levar em conta a ascensão de um conjunto significativo de nações recentemente industrializadas.

Como veremos, o projeto trilateralista é expressivo dessa busca, que, longe de ser uma tendência inata ao sistema, depende da atuação dos atores políticos internacionais. Conforme o próprio Cox enfatiza, o papel da agência dos atores políticos, embora esteja sempre condicionado, em algum grau, por fatores objetivos, é fundamental para compreender o desenlace dos conflitos internacionais.

Ao contrário do que encontramos em grande parte da literatura sobre as relações internacionais, a hegemonia é aqui considerada não somente como uma relação interestatal, mas como a penetração de um modo dominante de desenvolvimento.

Discutindo o conceito de hegemonia em Gramsci, Cox procurou aprofundar teoricamente o uso desse conceito para as relações internacionais, sem reduzilo ao uso comum da ideia de hegemonia como mera "supremacia" (no sentido de superioridade bélica). Um dos pontos mais enfatizados tanto por Cox quanto por outros autores chamados "neogramscianos" como Stephan Gill, é que "a hegemonia deriva dos estratos sociais dominantes dos Estados dominantes, desde que essas maneiras de agir e pensar tenham obtido a aquiescência dos estratos sociais dominantes de outros Estados” (GILL, 2007, p. 91-92). Tal ponto é fundamental para nosso estudo, já que consideramos o trilateralismo, junto com Gill, como um projeto proveniente dos estratos dominantes dos Estados mais poderosos, preocupados em garantir instituições internacionais asseguradoras de consentimento de países menos poderosos - ou, ao menos, de suas elites políticas.

6 Note-se que o termo "neoliberal" em Cox não se refere ao que comumente entendemos como neoliberalismo (teoria associada a nomes como Milton Friedman ou F. A. von Hayek), mas diz respeito exatamente ao tipo de liberalismo que vigorou no pós-Segunda Guerra, embutido de políticas keynesianas. 
Vale assinalar que, para Cox, num sistema hegemônico o conflito não é propriamente "eliminado", mas regulado e institucionalizado, e, muito importante, "a institucionalização do conflito dentro da potência dominante torna-se base para essa institucionalização também no plano global” (GARCIA, 2012, p. 202). A proposta trilateralista representa exatamente essa institucionalização preventiva do conflito internacional.

Tendo essas reflexões em mente, veremos agora quais foram as formulações elaboradas no bojo da Trilateral Commission, bem como o debate acerca delas dentro da entidade, que revelou inúmeras divergências. Analisaremos como o tema das organizações internacionais foi tratado pela comissão desde seus primeiros anos de existência; e, em seguida, examinaremos os três Task Force Reports (doravante TFRs) que a comissão publicou entre 1976 e 1977 sobre a reforma do sistema internacional, detalhando seus diagnósticos e receituários ${ }^{7}$. Alertamos que as notas com a descrição dos autores envolvidos na elaboração dos TFRs, embora longas, se fazem necessárias para demonstrar a relevância dos atores intelectuais, políticos e econômicos envolvidos na elaboração trilateralista, requisito essencial para a demonstração da hipótese apresentada.

\section{Trilateral: um projeto cosmopolita, liberal e institucionalista}

Desde o início de seus trabalhos, a Trilateral Commission visava a construção de uma hegemonia de novo tipo, modificando a arquitetura do sistema internacional. Já no TFR número 3, de 1974, era afirmado que tanto os países desenvolvidos quanto os países em desenvolvimento deveriam dar maior peso, em sua policy making, para sua "crescente interdependência"; para os trilaterais, isso significaria que a assistência e as medidas comerciais em favor dos países em desenvolvimento não deveriam ser tomadas apenas porque era "o certo", mas porque o "mundo trilateral” necessita crescentemente dos países em desenvolvimento como fontes de matérias-primas e como mercados de exportação (GARDNER, OKITA \& UDINK,

7 Os Task-Force Reports da Trilateral Commission - ou “relatórios de força-tarefa”, em tradução literal - eram densos estudos, escritos em geral ao longo de meses ou mesmo anos de consultas, quase sempre com autores especialistas nas temáticas em estudo, e provenientes das três regiões “trilaterais” (Estados Unidos, Japão e Europa Ocidental). Outra publicação importante da comissão eram os Trialogues, boletins mais curtos, de periodicidade trimestral, nos quais se descrevia os avanços alcançados nos objetivos da comissão, bem como a repercussão dos Task-Force Reports (TFRs) nas três regiões. Todas as passagens aqui citadas dessas fontes foram traduzidas por nós dos originais em inglês, que estão disponíveis no sítio eletrônico da entidade (www.trilateral.org). 
1974, p. 19). O principal autor do relatório, Richard Gardner, era um economista reconhecido nos Estados Unidos, tendo participado de conselhos governamentais e também de think tanks como a Brookings Institution. Seu pensamento estava fortemente marcado pela necessidade de construir instituições econômicas internacionais sólidas.

O novo sistema de relação entre os países, segundo a Trilateral, deveria respeitar o direito de independência e equidade sob a lei internacional para todos os membros da comunidade internacional, pobres e ricos, pequenos e grandes. O relatório dizia rejeitar também a existência de políticas especiais de comércio e assistência, que enlaçavam a África à Europa, a América Latina aos EUA, e o Sudeste Asiático ao Japão - continuidades dos antigos sistemas coloniais.

Nós precisamos evitar a tentação que há nos países trilaterais em um período de escassez de recursos a concentrar sua ajuda e favores comerciais em um grupo relativamente pequeno de países em desenvolvimento ricos em recursos enquanto ignora as necessidades do resto. (GARDNER, OKITA \& UDINK, 1974, p. 21)

A preocupação exposta nesse relatório mostra o viés liberal da proposta trilateralista, em sua defesa de que um genuíno livre-comércio favoreceria as nações e o sistema internacional como um todo - tema presente no pensamento ocidental desde a economia política clássica (especialmente Adam Smith e David Ricardo). Complementando o viés liberal, encontramos a visão institucionalista que reforça a necessidade de organizações econômicas e políticas internacionais fortes para regular os conflitos.

Como se sabe, a abordagem funcionalista de relações internacionais desenvolveu uma alternativa ao liberalismo do início do século, mantendo sua confiança no progresso e na cooperação internacional, mas acentuando que esses eram possíveis a partir da busca pela maximização dos benefícios materiais com menores custos. Nessa concepção, a cooperação nas organizações internacionais, preferível à competição por ser mais eficiente na conquista desses benefícios, geraria um efeito gradual de transbordamento (spill-over effect), no qual o sucesso de determinada forma de cumprimento de um objetivo ou função "transborda" para as demais áreas. O neofuncionalismo influenciaria claramente as teorias de Nye e Keohane (NOGUEIRA; MESSARI, 2005, p. 78; HERZ, 1997). 


\section{Interdependência complexa e organizações internacionais}

Mas foi apenas no décimo primeiro Task-Force Report da comissão, intitulado “A reforma das instituições internacionais”, e assinado por C. Fred Bergsten", Georges Berthoin ${ }^{9}$ e Kinhide Mushakoji10, que o tema da estrutura das instituições internacionais receberia atenção exclusiva. Apresentado e discutido na plenária geral da Trilateral Commission na capital canadense Ottawa, entre 9 e 11 de maio de 1976, o processo de elaboração do relatório contou com a colaboração de diversos nomes academicamente relevantes, como Robert Keohane, da Universidade de Stanford - um importante autor das relações internacionais -, Hayward Alker, do Massachussets Institute of Tecnology (MIT), e Donald Puchala, da Universidade de Columbia; e ocupantes de cargos políticos, como Thierry de Montbrial, chefe do Centro de Análise e Previsão do Ministério das Relações Exteriores da França. Os rascunhos do relatório foram discutidos em várias reuniões ocorridas entre dezembro de 1974 e junho de 1976.

O pressuposto do relatório era que o objetivo mínimo da organização internacional deveria ser ajudar a "evitar ações nacionais unilaterais" que ferem "a humanidade como um todo". Por isso, as instituições internacionais deveriam ajudar a "distribuir os custos e benefícios das ações internacionais” entre as nações envolvidas em um arranjo aceitável, assim como promover políticas desejáveis para atingir esses objetivos fundamentais (BERGSTEN, BERTHOIN \&

8 Economista ligado à Brookings Institution, trilateralista de primeira hora, C. Fred Bergsten era também membro do Council on Foreign Relations (CFR), o mais tradicional think tank de política externa dos Estados Unidos, onde a própria ideia da Trilateral Commission foi gestada. Bergsten chegou a ser membro do National Security Council sob a gestão Kissinger, onde dirigiu um grupo de discussão durante 1972 e 1973 intitulado "American interests in the Third World”, e continuou como o líder da discussão de um grupo similar no CFR entre 1974-75. De forma similar a Brzezinski, outro fundador da Comissão, Bergsten criticava a negligência da administração de Nixon em relação ao Terceiro Mundo e seu tratamento dessas regiões do globo como meros "peões no xadrez da política global”. Os argumentos de Bergsten nessa crítica à política externa kissingeriana enfatizavam a enorme importância do Terceiro Mundo como fornecedor de uma série de recursos para os países centrais, em especial os Estados Unidos, e também como receptor de investimentos americanos. Tanto para Brzezinski como para Bergsten, a política externa americana de então não estava levando em consideração tal relevância.

9 Representante-chefe da Comissão das Comunidades Européias no Reino Unido entre 1971 e 1973, ano em que a Inglaterra entra na comunidade, Berthoin começou sua carreira no serviço público francês como secretário do Ministério das Finanças. Após um período como chefe de equipe da subprefeitura de Alsácia-Lorena-Champagne, ele entrou para o serviço público europeu e serviu como primeiro secretário privado de Jean Monnet, então presidente da Alta autoridade da ECSC (European Coal and Steel Community), na qual passou a ocupar o cargo de representante em Londres em 1956.

10 K. Mushakoji, que fez carreira acadêmica em Bruxelas e Paris, na área de Ciência Política, foi diretor do Instituto de Relações Internacionais para estudos avançados sobre a paz e o desenvolvimento na Sophia University entre 1969 e 1975. Na época do relatório, era vice-reitor de programas da Universidade das Nações Unidas em Tóquio. 
MUSHAKOJI, 1976, p. 1). Mais uma vez, o viés institucionalista da proposta trilateralista fica claro.

Segundo o relatório, uma grande lição do passado é que as instituições internacionais podem tornar o mundo "seguro para a interdependência" e que, de fato, são necessárias para evitar esforços de nações individuais de "exportar" seus problemas internos umas para as outras. Diante disso, todas as questões da interdependência internacional deveriam ser trazidas junto à "governança de regras" e "arranjos internacionais efetivos". Para Bergsten, Berthoin e Mushakoji, atingir os objetivos das instituições internacionais se tornou mais complexo do que nunca por causa da intensidade e da extensão do padrão de interdependência entre as nações.

O termo "interdependência” já se fazia presente na literatura econômica do período; mas foi o conceito de interdependência complexa, tal como desenvolvido por Joseph Nye e Robert Keohane desde 1971, que se fez presente em maior ou menor medida nos relatórios aqui analisados - uma prova cabal da relação simbiótica entre as teorias de relações internacionais e as propostas normativas colocadas para as organizações internacionais. Como se sabe, a interdependência complexa se referia a uma situação entre uma série de países nos quais múltiplos canais de contato conectam as sociedades (ou seja, os Estados não monopolizam esses contatos), em que não há uma hierarquia de questões e em que a força militar não é utilizada pelos governos uns contra os outros. Ao analisar a política da interdependência, os autores enfatizaram que a interdependência não levaria necessariamente à cooperação, nem que suas consequências seriam automaticamente benignas (KEOHANE; NYE, 1971).

O tema da interdependência complexa aparece com proeminência em outro TFR sobre o tema das instituições internacionais: o TFR 14, "Em direção a um sistema internacional renovado", a cargo de Richard Cooper ${ }^{11}$, Karl Kaiser ${ }^{12}$ e Masataka Kosaka ${ }^{13}$. Embora só publicado em 1977, a elaboração do relatório começou ainda em dezembro de 1974, com uma sessão preliminar em Washington que incluiu Z. Brzezinski e 22 outros comissionários.

11 Economista Sênior no Council of Economic Advisers entre 1961 e 1963, e Deputy Assistant Secretary of State for International Affairs entre 1965 e 1966, publicou em 1968 The Economics of Interdependence (1968); na época do relatório, era diretor de Yale University.

12 Diretor do tradicional Instituto de Pesquisa da Sociedade Alemã para Política Externa.

13 Professor de Direito da Universidade de Kyoto, pesquisador associado ao International Institute for Strategic Studies de Londres, e estudioso da política externa japonesa. 
Entre os aspectos negativos da interdependência, segundo os autores, estariam as ameaças de proliferação nuclear e de nocivas mudanças ambientais, juntamente com a extrema pobreza, especialmente no sul da Ásia e em partes da África. A ideia forte aqui era a de que, em longo prazo, um “mundo com ordem” não seria provável se uma grande afluência em algumas regiões continuasse a coexistir com a pobreza abjeta em outras - cenário agravado já que a comunicação entre todas as partes crescia exponencialmente, permitindo aos pobres tomar conhecimento pleno sobre a opulência das parcelas privilegiadas (COOPER, KAISER \& KOSAKA, 1977, p. 180-190).

Para os autores do relatório de 1976, liderados por C. F. Bergsten, teria havido três grandes fases na construção de instituições internacionais. Cada uma delas teria tido dois objetivos: a ratificação e legitimação da estrutura de poder subjacente às relações internacionais no período, e a inserção de novos integrantes (newcomers) nessas relações. Em 1945, isso teria significado basicamente codificar a hegemonia americana e envolver os outros Estados-nações independentes, com exceção dos comunistas (entendidos como dropouts - aqueles que "pularam fora”). Em torno de 1960, isso significava um papel maior para a Europa Ocidental e o Japão, e a incorporação de países recentemente independentes da Ásia e da África.

Das lições sobre a história das organizações internacionais, segundo o relatório, poder-se-ia depreender que a própria existência de tais instituições internacionais, mais do que as regras específicas, é o que “inspira confiança” tanto nos setores públicos como governamentais - principalmente a "confiança” de que o progresso não será quebrado pelo conflito entre as nações. Os acordos internacionais fortaleceriam as forças de visão global (outward-looking) dentro de cada governo nacional (BERGSTEN, BERTHOIN \& MUSHAKOJI, 1976, p. 4). Podemos facilmente contrastar essa visão sobre o papel das organizações internacionais com a visão da teoria crítica de Cox e Gill: na ideia de interdependência, desaparecem as relações de dominação entre países e classes, entrando em seu lugar "assimetrias" a serem “manejadas" pela institucionalidade internacional.

\section{A “politização” nas organizações internacionais}

Outra lição da história, segundo o relatório, seria que organizações internacionais específicas funcionariam muito melhor que organizações com múltiplos propósitos para atingir metas concretas. Isso seria mais claro para 
questões essencialmente "não políticas", como a União Postal Internacional ou a OMS (Organização Mundial de Saúde). Mas também seria válido para instituições econômicas específicas, como o GATT (General Agreement on Tariffs and Trade) e o FMI (Fundo Monetário Internacional), quando comparadas a agências maiores das Nações Unidas (BERGSTEN et al., 1976, p. 5). A ligação de áreas de questões distintas (issue-area linkage) e a politização - ambas consideradas "prejudiciais ao progresso" de negociações internacionais - seriam mais bem evitadas nessas organizações. A indesejada ligação ocorreria quando países individuais atam o progresso em uma questão à solução de outras questões, como "preço" para sua cooperação ${ }^{14}$.

A politização também seria evitada em instituições específicas por conta do suposto consenso de que essas instituições são as melhores, talvez as únicas, em que "acordos sérios" poderiam ser feitos. Nas palavras do relatório, os mesmos países que iriam "esbravejar retoricamente" em organizações multipropositais, como nas várias agências das Nações Unidas, poderiam ao mesmo tempo negociar "séria e cooperativamente" em outras estruturas mais focadas em determinada questão. Nas palavras dos autores, "o foco mais técnico, e menor atenção pública, de tais organizações promovem esse resultado" (BERGSTEN, BERTHOIN \& MUSHAKOJI, 1976, p. 6, grifo nosso)

Não obstante, de acordo com o relatório, as organizações multipropositais, como a ONU, também teriam um importante papel a cumprir, pois elas poderiam, muito melhor que instituições específicas, legitimar esses novos conceitos internacionais. Elas poderiam coordenar as atividades de muitas organizações específicas e permitir aos governos nacionais que transmitam suas preocupações políticas, sem medo de desencaminhar o progresso das "metas objetivas" (BERGSTEN, BERTHOIN \& MUSHAKOJI, 1976, p. 6). Em suma, tratava-se de deslocar as instâncias centrais de decisão das grandes agências multipropositais para as inúmeras agências "especializadas" e "despolitizadas", diluindo assim os focos de conflito; mas manter organizações como a ONU como suporte para geração de consenso e legitimação do sistema internacional.

Ainda segundo o relatório, a politização da economia internacional residiria na própria lógica dos "Estados modernos de bem-estar [social]". Ao mesmo tempo, para os países em desenvolvimento mais fracos,

14 A articulação entre questões, segundo o relatório, vinha sendo um traço comum de negociações dentro da Comunidade Europeia, e dentro de todas as principais negociações comerciais no pós-Segunda Guerra. 
a interdependência aparece como um sistema de dependência. Daí o apelo de teorias que enfatizam elementos de dependência na economia mundial, incluindo as corporações multinacionais, e as quais formam a base para grande parte da retórica, senão da estratégia política, de muitos países em desenvolvimento. (COOPER, KAISER \& KOSAKA, 1977, p. 191, grifo nosso) ${ }^{15}$

Era por esse motivo, segundo o relatório, que alguns intelectuais, grupos e governos no Terceiro Mundo crescentemente advogavam uma “estratégia dissociativa” entre Norte e Sul. A cooperação requisitada tanto a curto como a longo prazo, segundo os autores, deveria estar baseada na convicção compartilhada que ela "maximiza o ganho geral" e "aumenta o bem-estar dos envolvidos". O papel das instituições, em especial do Banco Mundial, nesse quesito era considerado fundamental pela possibilidade de, através dele, garantir “assistência” no combate à “pobreza absoluta”.

A gestão de McNamara no Banco Mundial, cujo escopo ideológico ficou bem expresso em seu discurso de 1973 sobre a justiça social como um imperativo político, coadunava-se com os pressupostos trilateralistas (PEREIRA, 2010). A parceria dessa organização com a Trilateral começou com a participação do então presidente do banco, Robert McNamara, em diversas reuniões da comissão, culminando na elaboração, entre 1976 e 1978, de um relatório especial sobre agricultura na Ásia. O TFR escrito por Umberto Colombo ${ }^{16}$, D. Gale Johnson ${ }^{17}$ e Toshio Shishido18 intitulava-se "Reduzindo a desnutrição em países em desenvolvimento: aumentando a produção de arroz no Sul e Sudeste da Ásia”, e foi discutido na plenária da comissão em Bonn, entre 22 e 25 de outubro de 1977, com diversos especialistas do Banco (COLOMBO, JOHNSON \& SHISHIDO, 1978. 19

Francis Wells, então membro da diretoria de Cooperação Econômica da OCDE, afirmou claramente como o relatório da Trilateral estava em consonância

15 É uma das únicas passagens em que os teóricos da interdependência mencionam explicitamente a teoria da dependência, ainda que não seus autores.

16 Umberto Colombo (1927-2006) havia sido diretor do Comitê para Políticas Científicas e Tecnológicas da OCDE (Organização para a Cooperação e Desenvolvimento Econômico), cargo que ocupou entre 1972 e 1975; proveniente do setor privado, fora diretor-geral de Pesquisa e Desenvolvimento do conglomerado alimentício Montedison, de Milão.

17 Professor de Economia da Universidade de Chicago, Johnson serviu como consultor da Agência para Desenvolvimento Internacional entre 1962 e 1968, e como membro de uma série de órgãos oficiais de consultoria do Estado nos anos de 1960.

18 Presidente da Nikko Research Center, ocupou diversos cargos de Estado no Japão voltados para pesquisa em agricultura. Também trabalhou na embaixada japonesa em Washington.

19 O relato sobre a discussão desse TFR no encontro de Bonn pode ser encontrado em OKITA, 1978. 
com a abordagem das "necessidades básicas", delineada pelo encontro de 1977 do Development Assistance Committee da OCDE, a partir da influência do World Employment Conference da OIT (Organização Internacional do Trabalho), de 1976 - denotando a conexão da Trilateral com múltiplas instituições.

Em junho de 1978, o presidente americano Jimmy Carter anuncia seu plano de estabelecer uma "Comissão sobre a fome mundial" (Commission on World Hunger - CWH), num encontro privado na Casa Branca, com membros da Comissão Trilateral. O anúncio oficial seria em setembro, no mesmo período em que saiu o TFR coordenado por Colombo. O presidente da CWH coordenaria os esforços das agências das Nações Unidas com organizações internacionais para combater a fome. Para o cargo, foi designado o trilateralista Sol Linowitz, o que mostra como as ideias trilateralistas chegaram ao topo da política externa americana no governo Carter (SKLAR, 1980, p. 493).

A partir do conceito de hegemonia que apresentamos na primeira parte deste artigo, fica claro que a proposta trilateralista, centrada no conceito de interdependência, se mostrou como uma estratégia bastante elaborada de reordenamento das organizações internacionais.

\section{Compartilhando a liderança global e incorporando o "setor privado" na reforma das organizações internacionais}

Um segundo problema dos arranjos institucionais internacionais, segundo o relatório coordenado por Bergsten em 1976, seria a falta de consistência e "liderança decisiva”. A história teria mostrado que um sistema internacional efetivo requer um "zelador", e ele precisa ser um país relativamente grande ou um grupo de países, porque somente uma entidade assim seria tanto atenta a respeito dos efeitos sistêmicos de suas próprias ações e, portanto, ciente de seu papel de zelador, quanto apta para "aceitar os efeitos políticos domésticos das ações para defender o sistema” (BERGSTEN, BERTHOIN \& MUSHAKOJI, 1976, p. 10). Os Estados Unidos, desde o primeiro pós-guerra do século XX, viveram historicamente o dilema entre priorizar os interesses domésticos e cumprir o papel de garantidor de um sistema internacional estável. A questão que o relatório se colocava era simples, embora a resposta fosse difícil: sem os Estados Unidos, quem agora poderia cumprir tal papel?

Nenhum país ou grupo de países parecia apto a desempenhar essa liderança sozinho. A única alternativa, segundo o relatório, era a "liderança coletiva" ou 
“compartilhada”. Os EUA, o Japão, a Comunidade Europeia como grupo (ou a Alemanha e talvez mais um ou dois países da Europa Ocidental) e talvez "até mesmo" um ou dois países membros da OPEP e do Terceiro Mundo pareciam os prováveis parceiros em qualquer arranjo coletivo (BERGSTEN, BERTHOIN \& MUSHAKOJI, 1976, p. 12). Aqui se revela cristalinamente a ideia de uma aliança orgânica entre os países centrais, incorporando subalternamente os países considerados mais relevantes na periferia - a qual podemos entender melhor a partir do conceito de hegemonia anteriormente apresentado.

As propostas corretas para a reforma das organizações internacionais, segundo o relatório, deveriam se centrar em cinco questões-chave: a criação de novas instituições sobre determinadas questões críticas para a interdependência, não contempladas pelas existentes; a reforma de algumas das instituições existentes; a mobilização mais efetiva de ambos os sets de instituições; a legitimação de todas as instituições através da integração de newcomers e de dropouts, além de uma melhor coordenação entre as áreas-chave, de maneira a progredir na questão da liderança global.

Segundo o relatório, as ações para atingir algumas das demandas substantivas dos países em desenvolvimento, embora condição necessária para integrá-los dentro da ordem econômica internacional, não seriam o suficiente, e um segundo passo seria prover os países em desenvolvimento “chave” com algum papel político no processo de decision making internacional. É nesse ponto que foi cogitado, no relatório, a inclusão do Brasil, do Irã e do México na OCDE (BERGSTEN, BERTHOIN \& MUSHAKOJI, 1976, p. 25).

Em adição, as instituições deveriam procurar envolver o setor privado nos países onde quer que este fosse influente. "De fato”, afirmava o relatório, "grupos privados podem frequentemente serem mobilizados para ajudar a catalisar a ação internacional” (BERGSTEN, BERTHOIN \& MUSHAKOJI, 1976, p. 24). Aqui fica claro que a ligação orgânica com o grande empresariado (eufemisticamente chamado de "setor privado") era uma condição sine qua non para a viabilidade das propostas trilateralistas. Isso revela outro viés da elaboração trilateralista: a reforma das organizações internacionais deveria transcender os encontros formais entre Estados, incorporando os chamados “atores não estatais”, especialmente os empresários, em seu cerne. Uma espécie de “diplomacia privada”, na opinião dos trilateralistas, andaria de mãos dadas com a diplomacia oficial, e não por acaso o tema das consultas internacionais mereceu um TFR próprio. 
Publicado também em 1976 e intitulado "O problema das consultas internacionais", ele foi escrito por três ex-embaixadores que serviram nos EUA: Egidio Ortona ${ }^{20}$, J. Robert Schaetzel ${ }^{21}$ e Nobuhiko Ushiba ${ }^{22}$. O relatório dos exembaixadores destacava que a seriedade e a potencialidade da consulta estavam em proporção inversa à sua formalidade, algo que iria contra a excessiva ênfase em instrumentos tais como comitês ministeriais formais. Os contatos informais e discretos seriam essenciais ao trabalho de grupos mais formais e, além disso, a informalidade permitiria que as consultas fossem feitas no devido timing da política, de modo a poder influenciar propriamente o processo decisório (ORTONA, SCHAETZEL \& USHIBA, 1976).

\section{Influências e divergências}

A análise pormenorizada da influência direta da Trilateral Commission na formatação das instituições internacionais - e na criação de novas - foge ao escopo deste artigo. Entretanto, cabe mencionar brevemente alguns exemplos da influência direta da alternativa estratégica trilateralista, como mais uma forma de demonstrar nossa afirmação inicial de que a proposta em tela constituiu a mais elaborada estratégia cosmopolita dos anos de 1970.

Além da já mencionada relação com o Banco Mundial e com outros organismos, o exemplo talvez mais evidente da influência da comissão na construção de uma organização internacional foi a criação, em 1975, da Agência Internacional de Energia (IEA, em sua sigla em inglês), que foi explicitamente sugerida em um relatório de 1974 da comissão (CAMPBELL, CARMOY \& KONDO, 1974). Segundo dois importantes estudos sobre a Trilateral Commission, a criação da agência foi um produto direto desse relatório (SKLAR, 1980, p. 472; SHOUP; MINTER, 1977, p. 83).

Diversos membros da Trilateral Commission participaram de iniciativas de encontros internacionais informais, tais como os Economic Summits em Rambouillet, na França, em 1975, e em Porto Rico, em 1976, e também de iniciativas formais como a criação da CIEC (Conference on International Economic Cooperation), em 1975. Essas iniciativas eram por eles bastante valorizadas, pois constituíam um embrião do qual poderia emergir a tão almejada "liderança coletiva”. O Comitê Rey

\footnotetext{
20 Ex-embaixador da Itália para os Estados Unidos.

21 Ex-embaixador dos Estados Unidos para as Comunidades Europeias.

22 Ex-embaixador do Japão para os Estados Unidos.
} 
da OCDE, que ajudou a lançar as bases para as Multilateral Trade Negotiations, contou com a participação de trilateralistas; bem como o "Grupo das Nações Unidas de Pessoas Eminentes”, que tentou construir, na época, uma Comissão sobre Negócios Transnacionais (Commission on Transnational Enterprises). Isso mostra como os trilateralistas estavam inseridos nas mais relevantes iniciativas internacionais do período, tanto as formais como as informais.

Não obstante, é preciso notar que não havia consenso dentro da comissão sobre inúmeros assuntos, por exemplo, se encontros como o de Rambouillet seriam a melhor saída a longo prazo. A posição oficial da comissão, que podemos encontrar em uma resolução conjunta de seu comitê executivo, publicada ainda em 2 de dezembro de 1975, aprovava a realização do encontro, ocorrido entre 16 e 18 de novembro do mesmo ano, e ressaltava sua importância especialmente no que tangia à coordenação das políticas economias domésticas entre os "governos trilaterais". Como podemos ler no Trialogue que publicou tal resolução, um comissionário teria criticado a visão "diretiva” e não multilateral de Rambouillet, o que geraria um grande "ressentimento" nos países que ficariam de fora. O encarregado de fazer um relato sobre o encontro para a comissão, Otto Lambsdorff (membro do Bundestag alemão), propôs não tornar Rambouillet uma instituição regular (TRILATERAL COMMISSION, 1976, p. 14) - opinião que acabou não prevalecendo, pois os encontros de Rambouillet e Porto Rico acabaram se tornando os embriões do G-7 (BONHOMME, 2014).

O Trialogue número 11 revela que, para alguns, a proposta de criar novas instituições internacionais, presente no relatório de Bergsten de 1976, estaria "fora de momento" e seria "ambiciosa demais". A OCDE, para eles, seria ainda a melhor estrutura para fazer os progressos possíveis. Outra divergência relacionouse com a própria composição da OCDE: como vimos, o relatório "A reforma das instituições internacionais" propunha que o Brasil e o Irã fossem convidados para ingressar na OCDE. Mas, segundo o Trialogue, muitos membros da comissão foram relutantes em aceitar tais sugestões, alegando, entre outras razões, a natureza autoritária dos regimes domésticos no Irã e no Brasil (TRILATERAL COMMISSION, 1976, p. 12-13).

Outro reflexo do dissenso dentro da Trilateral Commission foi a publicação de dois task forces sobre segurança internacional, entre 1977 e 1978. O primeiro relatório (OWEN, SHONFIELD \& HOSOYA, 1977) favorecia maior cooperação econômica e funcional com a URSS, e apoio às políticas de controle de armas; já o segundo expressava claramente uma linha de confronto explícito, refletindo, 
possivelmente, os sentimentos antissoviéticos que reascendiam massivamente nos EUA e a opinião de novos ingressantes na comissão, ligados ao complexo industrial-militar (AZRAEL, LÖWENTHAL \& NAKAGAWA, 1978).

Em 1979, três acontecimentos mudariam os rumos dessas discussões de maneira decisiva. A invasão soviética ao Afeganistão e a revolução iraniana, ambas no final daquele ano, marcariam uma virada na elaboração de política externa das chamadas "sociedades trilaterais". Uma forte mudança de humor político se deu nos Estados Unidos, que em 1980 acabaram elegendo o republicano Ronald Reagan como presidente, legitimando um discurso fortemente nacionalista e unilateralista. Com o reconhecido revés da administração Reagan no que se referia à participação dos Estados Unidos em organizações internacionais, era previsível que as propostas trilateralistas se tornassem menos influentes e aos poucos fossem obliteradas. O terceiro acontecimento veio do campo econômico: o chamado "choque Volcker" - o aumento dos juros pelo FED, o Banco Central americano - recordou para o mundo o poder dos Estados Unidos como emissor da única moeda internacional, e colocou o problema da hegemonia americana em novos patamares.

Seria muito simplista tentar enxergar na atual configuração das organizações internacionais uma "realização" ou uma "não realização" das propostas trilateralistas - tal leitura certamente beiraria o "conspiracionismo". O formato dessas organizações é foco de disputa permanente, que tem uma historicidade própria e é condicionado por inúmeros fatores objetivos, como a economia internacional, a distribuição de poder bélico, entre tantos outros. Entretanto, a configuração atual de muitas das instituições internacionais que eram alvo da terapia trilateralista indica que recomendações essenciais presentes nas elaborações da comissão permaneceram vivas nas últimas décadas. Por exemplo, a estrutura dual marcada por um inegável fortalecimento de organismos supostamente mais "técnicos", como a OMC (Organização Mundial do Comércio, o antigo GATT), em detrimento dos organismos mais amplos politicamente e de formato multiproposital, como a ONU, que, entretanto, seguem legitimando uma certa ordem internacional.

\section{Conclusões}

Demonstramos, neste artigo, como a característica institucionalista e liberal das teorias que influenciaram diretamente os relatórios da Trilateral Commission nos anos de 1970, especialmente a partir de economistas como C. F. Bergsten e de 
teóricos de relações internacionais como Joseph Nye e Robert Keohane, constituiu a coluna vertebral da proposta trilateralista para a reforma das organizações internacionais, denotando a relação orgânica entre teoria analítica e propostas normativas.

Também demonstramos, a partir da análise detalhada dos relatórios da comissão sobre as instituições internacionais nos anos de 1970, em especial entre 1976 e 1977, que os trilateralistas não estavam preocupados com mudanças de curto prazo, mas sim com formatos institucionais de longa duração: uma reorganização institucional internacional numa hegemonia de novo tipo. Diante da crise de hegemonia, tratava-se, para os trilateralistas, de oficializar o "compartilhamento" do poder nessas instituições, incorporando novos membros (newcomers) e aproximando ou neutralizando a ação dos dropouts, em especial o bloco soviético.

Mostramos como, na visão estratégica trilateralista, as linhas gerais da reforma das organizações internacionais visavam uma estratégia de longo prazo de prevenção de conflitos internacionais, muito além de uma mera reação imediata a alguns deles. Segundo os trilateralistas, o único modo de construir a tão almejada "hegemonia compartilhada" entre os países "trilaterais" seria aprofundar os mecanismos de consulta e cooperação, além do fortalecimento das instituições internacionais. Um aspecto importante desse fortalecimento seria a "despolitização" das questões internacionais e o direcionamento das "questões mais sensíveis" a organismos técnicos específicos. O aprofundamento da institucionalização de organizações internacionais exigia, na visão trilateralista, uma maior participação do "setor privado" no processo decisório, dentro de um sistema de consultas internacionais que complementasse as relações oficiais entre Estados.

Retomando a teoria crítica que apresentamos no início do artigo, podemos afirmar que se tornou evidente, para um espectro considerável de atores políticos relevantes nos anos de 1970, que a aquiescência de estratos sociais dominantes de outros Estados, de que fala Stephen Gill, é uma premissa da hegemonia no plano internacional. A proposta trilateralista para a reforma das organizações internacionais representa perfeitamente as funções descritas por Robert Cox em suas análises das instituições internacionais.

Independentemente dos sucessos e fracassos relativos das inúmeras propostas trilateralistas, bem como de suas divergências internas, o que emerge como fato notável é a reunião de representantes de altos círculos empresariais, burocráticos e políticos dos países centrais, num cenário de crise de hegemonia, com o objetivo de não apenas forjar alianças, mas também de formatar concepções fundamentais 
acerca das instituições internacionais. Enquanto as tendências recentes das relações internacionais apontam para o enfraquecimento de organizações internacionais e para um ascenso nacionalista e anticosmopolita, o projeto trilateralista merece ser relembrado: não como uma proposta normativa capaz de resolver os problemas atuais, mas como um alerta de que o leque de alternativas estratégicas num cenário de crise pode ser mais diversificado do que o que a realidade aparente sugere.

\section{Referências}

ARRIGHI, Giovanni. O longo século XX: dinheiro, poder e as origens de nosso tempo. Rio de Janeiro: Contraponto; São Paulo: Ed. Unesp, 1996.

AZRAEL, Jemery; LÖWENTHAL, Richard; NAKAGAWA, Tohru. An overview of East-West Relations. Trilateral Commission: Task-Force Report n. 15, 1978.

BOHNOMME, Noel. Sommets du G7 et régulation économique internationale dans les années 1970. Presses Universitaires de France, 2014/2, n. 157. p. 111-130.

BRZEZINSKI, Zbigniew. Entre duas eras. América: Laboratório do mundo. Rio de Janeiro: Artenova, 1971.

Bergsten, C. Fred; BERTHOIN, Georges; MUSHAKOJI, Kinhide. The Reform of International Institutions. Trilateral Commission: Task-Force Report n.11, 1976.

CAMPBELL, John; CARMOY, Guy; KONDO, Shinichi. Energy: the imperative for a trilateral approach. Trilateral Commission. Task-Force Report n. 5, 1974.

COLOMBO, Umberto; JOHNSON, D. Gale \& SHISHIDO, Toshio. Reducing malnutrition in developing countries: increasing Rice production in South and Southeast Asia. Trilateral Commission: Task-Force Report n. 16, 1978.

COOPER, Richard; KAISER, Karl; KOSAKA, Masataka. Towards a renovated international system. Trilateral Commission: Task-Force Report n. 14, 1977.

COX, Robert. Gramsci, hegemonia e relações internacionais: um ensaio sobre o método. In. GILL, Stephen. (org.). Gramsci, materialismo histórico e relações internacionais. Rio de Janeiro: UFRJ, 2007.

COX, Robert; ACOBSON, Harold. The anatomy of influence: decision making in international organization. New Haven: Yale University Press, 1973.

GARCIA, Ana Saggioro. A internacionalização de empresas brasileiras durante o governo Lula: uma análise crítica da relação entre capital e Estado no Brasil contemporâneo. Tese de doutorado. Pontifícia Universidade Católica do Rio de Janeiro, 2012.

GARDNER, Richard; OKITA, Saburo; UDINK, B.J. A Turning point in the North-South economic Relations Trilateral Commission: Task-Force Report n. 3, 1974. 
GILL, Stephen. American Hegemony and the Trilateral Commission. Cambridge: Cambridge University Press, 1990.

GILL, Stephen. (org.). Gramsci, materialismo histórico e relações internacionais. Rio de Janeiro: UFRJ, 2007.

HERZ, Monica. Teoria da Relações Internacionais no Pós-Guerra Fria. Dados, vol. 40, n. 2, Janeiro de 1997.

HERZ, Monica; HOFFMAN, Andrea Ribeiro. Organizações Internacionais: definição e história. Rio de Janeiro: Campus/Elsevier, 2004.

HUNTINGTON, Samuel P.; CROZIER, Michel; WATANUKI, Joji. The crisis of democracy: report on the governability of democracies to the Trilateral Commision. New York: New York University Press, 1975.

KEOHANE, Robert O.; NYE, Joseph. Transnational Relations and World Politics, Cambridge, Massachussets: Harvard University Press, 1971.

NOGUEIRA, João Pontes; MESSARI, Nizar. Teoria das Relações Internacionais: correntes e debates. Rio de Janeiro: Elsevier, 2005.

OKITA, Saburo. Trilateral proposal debated. Doubling Rice production in Asia. Trialogue n. 17, 1978.

ORTONA, Egidio; SCHAETZEL, J. Robert; USHIBA, Nobuhiko. The problem of international consultatios. Trilateral Commission. Task-Force Report n. 12, 1976.

OWEN, Henry; SHONFIELD, Andrew; HOSOYA, Chihiro. Collaboration with communist countries in managing global problems: an examination of the options. Trilateral Commission: Task-Force Report n.13, 1977.

PEREIRA, J.M.M. O Banco Mundial como ator político intelectual e financeiro. 1944-2008. Rio de Janeiro: Civilização Brasileira, 2010.

SHOUP, Laurence H.; MINTER, William. Imperial Brain Trust. The Council on Foreign Relations and the United States Foreign Policy. Monthly Review Press, 1977.

SKLAR, Holly (org.) Trilateralism: managing dependence and democracy. Boston: South and Press, 1980.

TRILATERAL COMMISSION. Trialogue. A bulletin of American-european-japanese affairs. $\mathrm{N}^{\circ}$ 09, dezembro de 1975/janeiro de 1976.

WALLERSTEIN, Immanuel. O declínio do poder americano. Rio de Janeiro: Contraponto, 2004. 


\title{
A Diretiva Europeia sobre Aquisições em Segurança e Defesa: Impactos na Logística de Defesa
}

\section{The European Directive on Acquisitions in Security and Defence: Impacts on Military Logistics}

\author{
DOI: $10.21530 /$ ci.v12n2.2017.672
}

\author{
Bruna Rohr Reisdoerfer ${ }^{1}$ \\ Luiz Rogério Franco Goldoni²
}

\section{Resumo}

A cadeia de suprimento da logística de defesa tende a ser alvo de forte protecionismo estatal e não faz parte da jurisdição de tratados internacionais. Entretanto, a União Europeia possui uma política única de aquisição em assuntos de segurança e defesa. Ela tem como objetivo, através da diminuição do protecionismo, facilitar o desenvolvimento de um mercado de equipamentos de defesa que iria reduzir a duplicação, aumentar a competição industrial e assim diminuir os preços dos equipamentos dentro do bloco. Todavia, na prática, ocorre a duplicação das capacidades estratégicas dos países. A hipótese do trabalho é que a Diretiva Única 2009/81/EC, relativa a aquisições em segurança e defesa é uma resposta dos países do bloco europeu às pressões de autoajuda do sistema internacional advindas da configuração securitária do pós Guerra Fria. Ela é, portanto, reativa e não ativa às dinâmicas internacionais e é utilizada como instrumento estatal. Todavia, essa característica acaba levando a Diretiva a uma eficiência secundária, pois os países europeus buscam mecanismos para escapar da livre concorrência imposta por ela e para manter certa proteção à capacidade nacional de produção de armamentos sensíveis. O presente trabalho pretende verificar como se estrutura essa política de aquisições na União Europeia - bem como demonstrar os antecedentes que permitiram o seu desenvolvimento.

Palavras-chave: Segurança e Defesa; Logística de Defesa; Política de Aquisição; União Europeia; Diretiva Única 2009/81/EC

1 Escola de Comando e Estado-Maior do Exército. Rio de Janeiro/RJ, Brasil. E-mail: brunareisdoerfer@gmail.com

2 Escola de Comando e Estado-Maior do Exército. Rio de Janeiro/RJ, Brasil.

Artigo submetido em 15/05/2017 e aprovado em 24/08/2017. 


\begin{abstract}
The supply chain of military logistics is usually heavily protected by the state and is not part of the jurisdiction of international treaties. However, European Union has a single defence procurement policy. It aims, through the reduction of protectionism, to facilitate the development of a defence equipment market that reduces duplication, increase industrial competition and thus decreases the prices of equipment within the bloc. However, in practice, there has been a doubling of countries' strategic capabilities. The working hypothesis is that EU Defence and Security Procurement Directive 2009/81/EC is an answer of the European bloc countries to the self-help pressures of the International System stemming from the post-Cold War security configuration. It is therefore, reactive and not active to international dynamics and is used as a state instrument. However, this characteristic leads the Directive to a secondary efficiency, since the European countries seek mechanisms to escape the free competition imposed by it and to maintain some protection to the national capacity to produce sensitive weapons. The objective of the work is to verify how this defence procurement policy is structured in the European Union, as well as, to demonstrate the antecedents that allowed its development.
\end{abstract}

Keywords: Defence and Security; Military Logistics; Defence Procurement; European Union; Directive 2009/81/EC

\title{
Introdução
}

A logística de defesa é um dos componentes da "grande estratégia”3 nacional e auxilia o Estado a alcançar seus objetivos em tempos de paz e de guerra através do suporte ao deslocamento, manutenção, mobilização e posicionamento de suprimentos, tropas e equipamentos (SILVIA; MUSETI, 2003). De forma específica, a política de aquisição de armamentos, sistemas e serviços de segurança e defesa é prerrogativa estatal e se configura como um dos pilares essenciais da cadeia de suprimento de um país (RUSSEL, 2011). É ela que vai determinar quais aquisições devem ser feitas, qual a melhor forma de fazê-las e com quem se deve comercializar a fim de alcançar os melhores benefícios para a segurança e defesa nacionais. Ademais, a política de aquisições determina o equilíbrio entre a importação de produtos ou a compra interna deles. Por isso, ela está também

3 Segundo Silva (1981, p. 25), grande estratégia ou estratégia geral é “arte da competência exclusiva do governo que coordena, dentro de um Conceito Estratégico Fundamental, todas as atividades políticas, econômicas, psicossociais e militares que visam concorrentemente à consecução dos objetivos nos quais se consubstanciam as aspirações nacionais de unidade, de segurança e de prosperidade crescente”. 
diretamente interligada à política de fomento à base industrial de defesa de uma nação (MARKOWNSKI; HALL; WYLIE, 2010). Por ser tão importante para a soberania nacional, a cadeia de suprimento da logística de defesa - especificamente a política da base industrial de defesa e a de aquisições - tende a ser alvo de forte protecionismo estatal e não faz parte da jurisdição de tratados internacionais (MARKOWNSKI; HALL; WYLIE, 2010).

Todavia, a União Europeia possui uma política única de aquisição em assuntos de segurança e defesa que está incorporada nas leis dos países membros (TRYBUS, 2014). Essa política está consubstanciada na Diretiva Única 2009/81/EC da União Europeia (UNIÃO EUROPEIA, 2009). As diretivas são instrumentos jurídicos, pelos quais as políticas da União Europeia são aplicadas nos Estados membros. Para que elas tenham efeito no âmbito nacional, os países têm de transpô-las para o seu direito nacional. Portanto, pode-se dizer que as diretivas estabelecem uma política comum a ser seguida pelos países, mas deixam margem para que os Estados elaborem legislação própria para determinar como as regras serão aplicadas. As diretivas têm prazos máximos para serem transpostas nacionalmente. Tais prazos são determinados quando da adoção da diretiva pela União Europeia. Os países que não cumprirem o prazo estipulado para transposição sofrem processos de infração junto ao Tribunal de Justiça da União Europeia (EUROPEAN UNION, 2015).

A Diretiva Única 2009/81/EC (UNIÃO EUROPEIA, 2009) faz parte do chamado Pacote de Defesa da União Europeia, implementado em 2009, mas que tem origem (como será demonstrado) no fim dos anos 1990 com os movimentos em prol de regulamentação comum entre os países europeus em matéria de armamentos. O supracitado pacote engloba - além da diretiva objeto deste estudo - um comunicado da Comissão Europeia (intitulado "Estratégia para uma indústria de defesa europeia mais forte e competitiva") e outra diretiva referente à transferência de produtos de defesa dentro do bloco (a Diretiva/2009/43/EC) (EUROPEAN PARLIAMENT, 2015, p. 8).

Na teoria, o objetivo da política de aquisição comum é, através da diminuição do protecionismo dentro do bloco, facilitar o desenvolvimento de um mercado de equipamentos de defesa que iria evitar a duplicação, aumentar a competição industrial e assim reduzir os preços dos equipamentos dentro do bloco (EDWARDS, 2011). Ela é uma tentativa de manter a competitividade do mercado de armamentos europeu frente à pressão por diminuição nos orçamentos de defesa do bloco no pós Guerra Fria (JONES, 2007) e, principalmente, frente ao protagonismo de Estados Unidos e Rússia e a crescente presença da China no mercado internacional de armamentos convencionais (SIPRI, 2017). No início da presente década, pela 
primeira vez, a China apareceu como um dos cinco principais exportadores de material bélico, desbancando posição ocupada tradicionalmente pelo Reino Unido (HOLTON et al., 2013; GOLDONI; DOMINGOS NETO, 2014).

No ano de 2016, Estados Unidos e Rússia juntos representavam mais de $50 \%$ do mercado de exportações de armamentos convencionais. França (quarto lugar no ranking global, com 6\%), Alemanha (quinto lugar, com 5,6\%) e Reino Unido (sexto lugar, com 4,6\%) juntos foram responsáveis por um pouco mais de $16 \%$ das exportações de material bélico no mundo. Destaca-se que, entre 2007 e 2016, a China (terceira colocada no ranking de 2016) aumentou sua participação nesse mercado de 3,8\% para 6,2\% (FLEURANT et al., 2017) ${ }^{4}$.

O presente estudo, ao focar sobre a dinâmica dos países europeus na busca pela manutenção da competitividade no mercado global de armamentos, mostrase importante para a realidade brasileira em vista das parcerias estratégicas com França (construção do submarino nuclear brasileiro e de satélite de observação), Suécia (construção do caça de combate Gripen) e Alemanha (compra de carros de combate Leopard).

Nesse contexto, questiona-se quais foram os fatores que influenciaram os Estados europeus a buscarem uma política de aquisições em segurança e defesa comum na União Europeia. Parte-se da hipótese de que a Diretiva Única 2009/81/ EC (UNIÃO EUROPEIA, 2009), relativa a aquisições em segurança e defesa, é uma resposta dos países do bloco europeu às pressões de autoajuda do sistema internacional advindas da configuração securitária do pós Guerra Fria. Ela seria, portanto, reativa e não ativa às dinâmicas internacionais e seria utilizada como instrumento estatal. Todavia, essa característica acaba levando a Diretiva a uma eficiência secundária, pois os países europeus buscam mecanismos para se proteger da livre concorrência imposta por ela e para manter certa proteção à capacidade nacional de produção de armamentos sensíveis.

O presente trabalho tem como objetivo desenvolver um esforço analítico acerca da Diretiva Única 2009/81/EC (UNIÃO EUROPEIA, 2009), a fim de verificar quais são seus antecedentes e como ela se estrutura. Conjuntamente à revisão bibliográfica de literatura especializada, faz-se uma análise de conteúdo implícito e explícito (BARDIN, 2002; CAVALCANTE; CALIXTO; PINHEIRO, 2014) da jurisdição europeia referente à diretiva em questão e se emprega o rastreamento de processo (VENESSON;

4 Top 10 de países exportadores de armamentos do mundo entre 2012-2016 por porcentagem da parcela global (em ordem decrescente): Estados Unidos (33\%), Rússia (23\%), China (6,2\%), França (6\%), Alemanha (5,6\%), Reino Unido (4,6\%), Espanha (2,8\%), Itália (2,7\%), Ucrânia (2,6\%) e Israel (2,3\%) (FLEURANT et al., 2017). Para série histórica detalhada, ver GRAF. 1 e 2 do presente artigo. 
WIESNER, 2014) para auxiliar a prospectar os antecedentes que levaram os países a desenvolverem a legislação conjunta em área tão sensível ao estado-nação.

Cabe, inicialmente, diferenciar a Diretiva Única Europeia 2009/81/EC (UNIÃO EUROPEIA, 2009) das regulamentações da Organização do Tratado do Atlântico Norte (OTAN). A OTAN possui diversas agências subsidiárias que dão suporte para as aquisições no setor de defesa, por exemplo, a Agência de Suporte da OTAN. Ela é a agência que provê serviços e logística integrada e tem como missão prover suporte coletivo e individual aos Estados membros da aliança (TRYBUS, 2014). Esses organismos da OTAN não visam regular as aquisições de defesa dos Estados membros como a Diretiva da União Europeia faz, pois não possuem legislação vinculante a ser transposta para a lei nacional. Isto é, não é obrigatório que um país utilize os regulamentos das agências da OTAN para a aquisição de serviços ou produtos de defesa. Ela é somente um mecanismo de auxílio disponível aos países membros que assim desejarem. Uma das funções da agência é efetuar contratos públicos individuais ou em grupos como parcerias de apoio (TRYBUS, 2014).

Ademais, convém explicitar que o processo de saída do Reino Unido do bloco europeu - chamado de BREXIT - produz incertezas quanto ao futuro das instituições europeias, sendo difícil prever as consequências desse movimento na Diretiva 2009/81/EC (UNIÃO EUROPEIA, 2009). Destaca-se que o presente trabalho não objetiva prospectar os impactos do BREXIT na Diretiva Única. Tal tema pode ser assunto de uma nova agenda de pesquisa assim que houver maiores dados sobre o processo de negociação entre a União Europeia e o Reino Unido. Entretanto, uma nota informativa da Câmara dos Comuns declara que a saída do Reino Unido da União Europeia pode ter pouco impacto na cooperação em defesa do continente no que tange à logística de defesa (ALLISON, 2016).

A saída da UE não irá proibir o RU de trabalhar de perto com as nações europeias individuais para aquisição conjunta de equipamentos, exercícios ou desenvolvimento conjunto de operações militares. As negociações da saída irão decidir se as duas diretivas de defesa da UE serão mantidas. Estas diretivas são desenhadas para fazer com que o mercado interno de defesa europeu trabalhe melhor e para aumentar a competição no setor europeu de defesa. A maioria das companhias de defesa do RU argumentavam, antes do voto favorável, pela manutenção. (HOUSE OF COMMONS, 2016 apud ALLISON, 2016, tradução nossa) ${ }^{5}$

5 Do original em inglês: "Exit from the EU will not prohibit the UK from working closely with individual European nations to jointly procure equipment, exercise or deploy together on military operations. Withdrawal negotiations will decide whether the substance of two EU defence directives are retained. These directives are designed to make 
O presente artigo é separado em cinco seções (além desta introdução). Na primeira, é feita uma breve discussão teórica em torno da cooperação em defesa. Em seguida, são investigados os precedentes que impulsionaram o desenvolvimento de uma diretiva única de aquisições de material de defesa na União Europeia. A terceira seção analisa a Diretiva Europeia Relativa a Aquisições em Segurança e Defesa (Diretiva Única 2009/81/EC (UNIÃO EUROPEIA, 2009)), especialmente seu escopo, objetivos e diretrizes. A quarta seção aborda o desenvolvimento do avião de transporte A400M Atlas, projeto europeu que pode produzir efeito positivo na busca por uma maior cooperação em logística de defesa. Por fim, as considerações finais apresentam reflexões sobre o impacto da Diretiva na cooperação em segurança e defesa do bloco europeu.

\section{Cooperação em defesa: breve análise teórica das relações internacionais}

A cooperação nas relações interestatais é tema de acalorado debate entre diversas correntes teóricas, tanto na literatura específica acerca da cooperação europeia - chamada de estudos europeus - quanto na de teoria das relações internacionais (ROSAMOND, 2000). Uma análise pormenorizada desses debates foge do escopo e fôlego do presente artigo. Cabe aqui, de forma breve, apontar as diretrizes teóricas seguidas pelo trabalho. Adota-se a visão do realismo neoclássico acerca da cooperação em defesa na União Europeia.

As premissas básicas da escola realista das relações internacionais defendem que a política internacional é baseada nas relações de poder, isto é, em relações materiais (DYSON, 2010) (e não em relações subjetivas como identidade, cultura e construções sociais, como defendem os construtivistas (WENDT, 1992)). A ausência de autoridade central (em outras palavras, a anarquia do sistema internacional) faz com que os países só possam contar com suas próprias forças para garantir sua sobrevivência, o que comumente se denomina como sistema de autoajuda (WALTZ, 2000). Isso os leva constantemente a se preocuparem com as ameaças advindas do sistema internacional. Como a anarquia condiciona o mecanismo de autoajuda, os Estados são compelidos a dar atenção em como o poder está distribuído entre eles. O cálculo do poder relativo de um país frente aos demais atores do sistema representa, em última instância, sua capacidade de sobrevivência (MENDES, 2013). 
A busca pela manutenção ou revisão desse poder relativo remete à análise sobre o equilíbrio de poder e a imagem da balança de poder, temas amplamente discutidos em Morgenthau (2003). Todavia, acrescenta-se aqui a ideia de Walt (1987) sobre a balança de ameaças, segundo a qual os Estados não temem de forma igual todos os países e, sim, os que representam as maiores ameaças. Segundo Walt (1987), a intensidade das ameaças securitárias varia de região para região conforme a exposição dos países à estratégia e interesses dos Estados centrais. Essa dinâmica, de acordo com Dyson (2010), leva à convergência de interesses, conduzindo a padrões específicos de cooperação regional. Dessa forma, os Estados podem fazer alianças com países mais fortes a fim de ganhos oportunistas (DYSON, 2010).

$\mathrm{Na}$ lógica do Estado como ator principal, a escola realista defende que as instituições de cooperação em segurança e defesa servem como um mecanismo dos Estados para alcançar seus objetivos nacionais (MEARSHEIMER, 1995), pois são eles quem as criam, moldam e escolhem quando obedecê-las (WALTZ, 2000). Ainda conforme Waltz (2000), as instituições internacionais e a cooperação seriam instrumentos empregados pelos países para garantir sua sobrevivência no sistema de autoajuda. A utilização desses mecanismos e a busca por uma maior cooperação entre os Estados seriam impulsionadas pelo término da Guerra Fria. A estrutura bipolar possibilitava uma dinâmica em que as políticas das potências centrais tinham preponderância frente a outras iniciativas de cooperação, inclusive regionais. Como qualquer ganho de poder por um lado representaria uma perda de poder para o outro, a manutenção do equilíbrio de poder fazia com que as superpotências se comprometessem com a defesa e securitização de suas zonas de influência (WALTZ, 2000). Portanto, segundo essa ótica, as instituições não teriam poder de mudar a ação estatal, como defende a corrente teórica neoliberal das relações internacionais (KEOHANE; NYE, 2011) ${ }^{6}$.

Essas premissas poderão ser percebidas mediante análise dos condicionantes da Diretiva Única 2009/81/EC da União Europeia (UNIÃO EUROPEIA, 2009) e de sua estrutura. Pois, como será explicitado, ela não molda a ação estatal e, sim, serve de instrumento do Estado quando lhe é conveniente. Jones (2007) estuda o comportamento das empresas de defesa europeias durante e após a Guerra Fria. No decorrer daquele período, os países europeus cooperavam mais com os Estados Unidos e suas empresas de armamentos; quase não havia cooperação entre os países e as empresas europeias. Com a quebra da ordem bipolar, Alemanha,

6 Conforme Mearsheimer (1995), o neoliberalismo só teria validade para explicar a influência das instituições em situações nas quais os Estados não têm nada a perder. 
França e Reino Unido passariam a empreender esforços para o desenvolvimento e a produção conjunta de armamentos; bem como a realizar fusões e aquisições. As potências europeias objetivavam diminuir a dependência frente aos Estados Unidos e aumentar a capacidade de projetar poder autonomamente (JONES, 2007). Todavia, tais esforços somente surtiriam efeitos no século XXI.

A guerra no golfo Pérsico, em 1991, a Guerra na Bósnia, em 1995, e a do Kosovo, em 1999, evidenciaram que as potencias europeias continuavam dependentes dos Estados Unidos para desenvolver e sustentar operações militares (HOWORTH, 2007). Um relatório da Comissão Europeia de 1997 concluiu que havia um risco de que a indústria de defesa daquele continente pudesse ser reduzida a exercer o papel de subfornecedora em contratos principais com os Estados Unidos, ficando a tecnologia principal reservada para as empresas americanas (EUROPEAN COMMISSION, 1997).

O poder americano criou uma profunda preocupação entre os governos europeus e líderes industriais de que uma falha em colaborar através de fusões e aquisições, coprodução e codesenvolvimento de projetos pode colocá-los em perigo de dependência dos Estados Unidos de plataformas e armas. (JONES, 2007, p. 180, tradução nossa) ${ }^{7}$

Dentro da escola realista de relações internacionais, pode-se perceber ao menos três vertentes: realismo clássico, realismo estrutural e realismo neoclássico (RYNNING, 2011). O realismo clássico entende que o foco está na agência e não na estrutura. Isto é, são as características internas de cada país (história, escolhas políticas dos líderes etc.) que explicam as ações estatais (RYNNING, 2011). Já o realismo estrutural trabalha com a ideia de que é somente a estrutura do sistema internacional - sem intervenção de variáveis no nível da agência - que produz os principais incentivos às ações estatais (WALTZ, 2002). Já o realismo neoclássico entende que as ações estatais são condicionadas pela estrutura internacional, mas as variáveis internas agem como intervenientes, determinando o tempo e a forma de reposta dos Estados à balança de ameaças do sistema internacional (DYSON, 2010).

Portanto, segundo Dyson (2010), é o sistema internacional (especialmente a balança de ameaças e a anarquia) que pressiona a ação estatal a agir de forma

7 Do original em inglês: "US power created deep concern among European government and industry leaders that a failure to collaborate through M\&As, coproduction projects, and codevelopment projects might place them in danger of dependence on the US for weapons and platforms” (JONES, 2007, p. 180). 
racional e com ambição pelo poder; o ator que não agir assim será punido com declínio, derrota ou mesmo destruição. Portanto, a lógica da anarquia internacional dirige a mudança no nível doméstico de forma que o Estado produza as reformas necessárias para se conformar com os novos desafios securitários. Assim, haveria três opções de ação para os Estados frente a uma mudança na natureza das ameaças no sistema internacional: 1) continuação das práticas já existentes essa opção irá punir os Estados com estagnação, perda de influência e poder; 2) emulação da melhor prática, isto é, imitação das inovações militares do Estado com capacidade mais efetiva; 3) inovação: invenção de novas práticas (DYSON, 2010). Conforme o mesmo autor (2010), a propensão do Estado para emular ou inovar depende da relação de três fatores: recursos tecnológicos, intensidade da competição/ameaças (se a ameaça for mais intensa, os Estados irão preferir emular devido à certeza que ela traz, pois a inovação traz riscos de não dar certo) e opção de alianças (que pode incentivar a se alinhar ao polo para tirar proveito das inovações dos países).

Portanto, de acordo com o realismo neoclássico de Dyson (2010), a cooperação em defesa na União Europeia seria a forma que os Estados europeus escolheram para emular parcialmente as inovações militares americanas. Assim, como será analisado na seção seguinte, a Diretiva Única 2009/81/EC relativa a aquisições em segurança e defesa (UNIÃO EUROPEIA, 2009) seria uma resposta dos países do bloco europeu às pressões de autoajuda do sistema internacional advindas da configuração securitária do pós Guerra Fria.

\section{Precedentes da Diretiva Única de Aquisição da União Europeia}

No imediato pós Segunda Guerra Mundial, os países da Europa ocidental contavam com a cooperação com os Estados Unidos para reconstruir suas indústrias de defesa e se rearmarem ${ }^{8}$. Essa parceria se dava através de licenças e transferência de tecnologia (EDWARDS, 2011). Foi somente nos anos de 1960, quando os europeus já haviam se restabelecido, que a cooperação intrabloco se iniciou como forma de competir com as empresas americanas no mercado

8 Tal prática remete ao Lend-Lease Act ou Bill aprovado pelo congresso estadunidense em março de 1941. “Através deste instrumento jurídico, o Presidente dos Estados Unidos podia, discricionariamente, vender, arrendar, emprestar ou trocar armas ou outros equipamentos para defesa com qualquer país, 'cuja defesa o Presidente julgasse vital para a defesa dos Estados Unidos” (ALVES, 2002, p. 117). 
de armamentos. Tal cooperação se manteve em níveis triviais, pois era elevado o protecionismo entre os países (EDWARDS, 2011). O fim da Guerra Fria levou a um corte nos orçamentos de defesa (LESKE, 2013). Essa tendência passou a ser invertida com a emergência das chamadas "novas ameaças" (SALES, 2016). Somente após 2001 há retomada do crescimento dos investimentos em defesa, provavelmente por influência do 11 de setembro (SALES, 2016; SIPRI, 2016; YANG et al., 2015).

O perigo de um Estado territorial nuclear expansionista deu espaço a ameaças híbridas e irregulares fora das fronteiras nacionais (como terrorismo, armas de destruição em massa etc.). Isso, aliado à complexidade e vulnerabilidade da logística para operações além-teatro ${ }^{9}$ e à pressão dos Estados Unidos por maior divisão de custos na OTAN, levou à necessidade de cooperação por parte dos países europeus para manter a capacidade combativa com menores custos (KISTERSKY, 1996; JONES, 2007; KING, 2011).

Após a dissolução da União Soviética, os Estados Unidos chegaram a ser responsáveis por quase $60 \%$ do mercado de exportação de armamentos convencionais (o ápice do domínio mercadológico estadunidense ocorreu em 1992, conforme pode ser observado nos GRAF. 1 e 2) (SIPRI, 2017). O medo do monopólio e de que as empresas europeias fossem reduzidas a um papel secundário ou subsidiário, aliado à incerteza da proteção americana caso necessário, pressionou os países europeus a cooperarem através de projetos conjuntos, fusões e aquisições (JONES, 2007). Somente a partir de 1999 os norte-americanos teriam seu predomínio reduzido nas exportações globais de armas convencionais (conforme pode ser observado no GRAF. 1), devido, principalmente, à recuperação dos investimentos russos. Na série histórica analisada (1989-2016), chama também atenção o encolhimento das exportações britânicas e o crescimento chinês, que dobrou sua porcentagem nas exportações globais de armamentos convencionais (ver GRAF. 2) ${ }^{10}$.

9 Operações além-teatro dizem respeito às operações fora do território previsto para que a força militar desenvolva as suas funções (HURA et al., 2000).

10 Foram elaborados dois gráficos para a representação temporal (um para a representação de Estados Unidos e URSS/Rússia e outro para representação de Alemanha, França, Reino Unido e China) a fim de facilitar a visualização devido aos altos valores de Estados Unidos e URSS/Rússia. A base de dados sobre transferência de armamentos do SIPRI não visa disponibilizar o valor financeiro internacional do comércio de armas, mas sim indicar o volume de equipamentos militares transferidos no mundo (FLEURANT et al., 2017). 
Gráfico 1 - Variação percentual na participação dos Estados Unidos e União Soviética (URSS)/Rússia no mercado global de exportação das principais armas convencionais entre 1989-2016

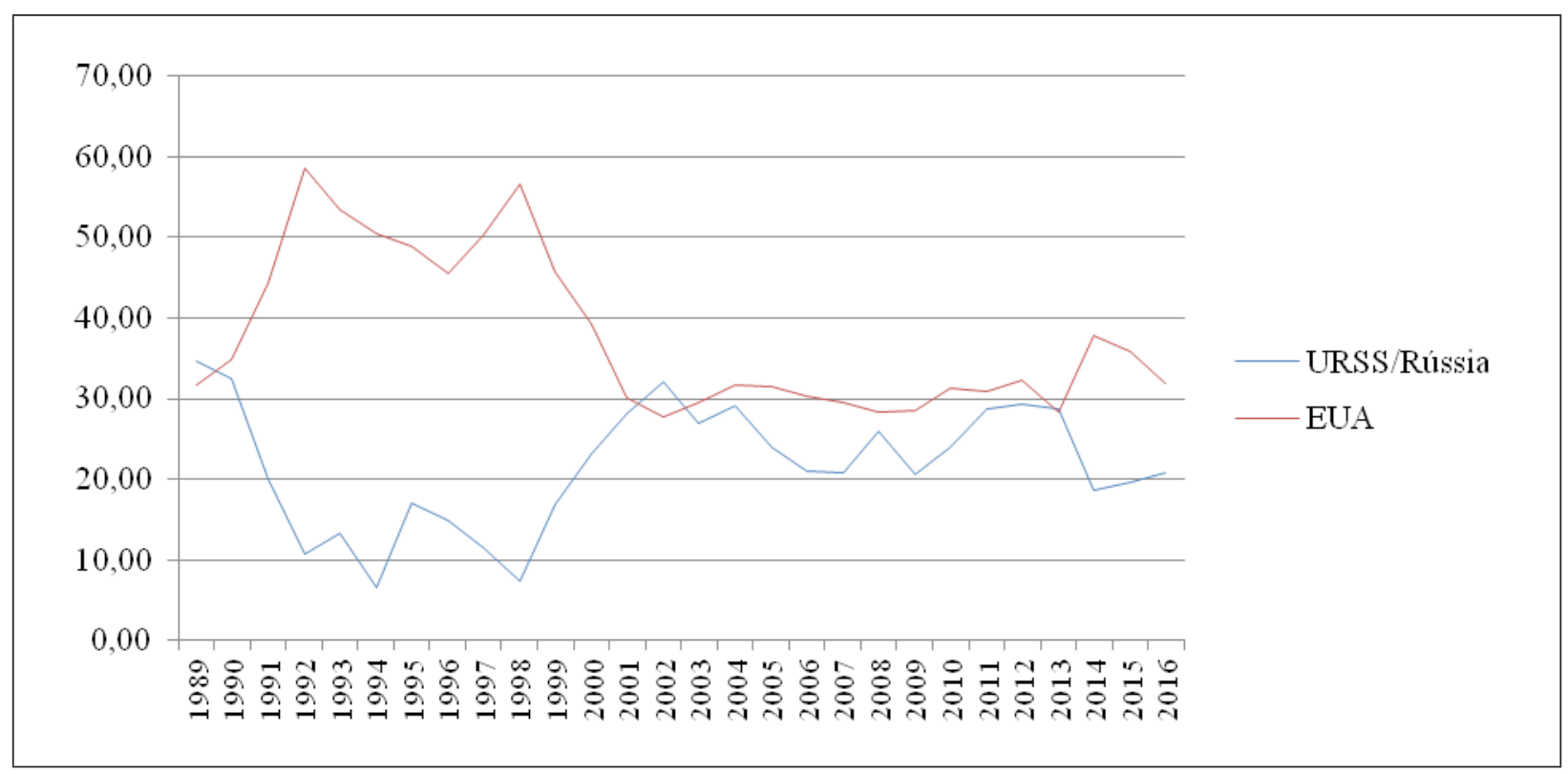

Fonte: elaboração própria com base nos dados de SIPRI, 1989-2016.

Gráfico 2 - Variação percentual na participação de Reino Unido, França, Alemanha Ocidental/República Federal da Alemanha e China no mercado global de exportação das principais armas convencionais entre 1989-2016

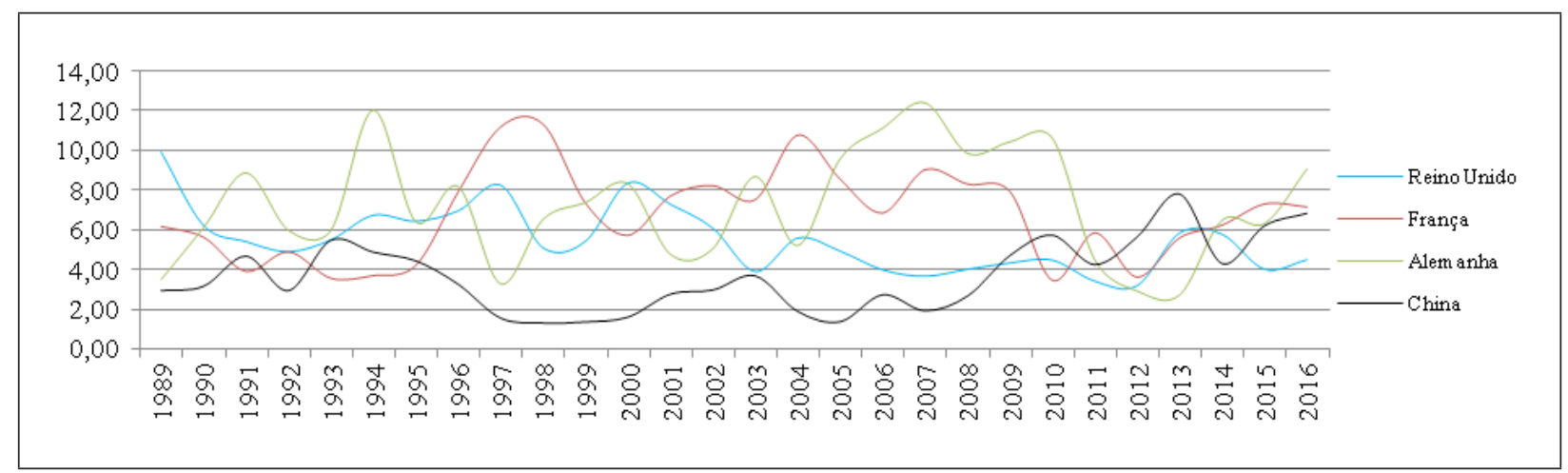

Fonte: elaboração própria com base nos dados de SIPRI, 1989-2016.

Com o fim da Guerra Fria e a diminuição do orçamento de defesa, os Estados Unidos adotaram a estratégia das campeãs nacionais para dominar o mercado internacional. Isto é, houve fusões e aquisições para melhorar a eficiência das empresas americanas (JONES, 2007). Nos anos de 1990, Lockheed Martin e Boeing eram as empresas de armamentos dominantes no mundo (JONES, 2007). Isso impactou diretamente a Europa, que via esse crescimento como uma possível ameaça: 
A indústria de defesa europeia está muito fragmentada para ser sustentável. A queda acentuada da demanda após o fim da Guerra Fria, combinada com a feroz concorrência de corporações "gigantes” recém-criadas nos Estados Unidos colocou em risco o futuro desta indústria. (EUROPEAN COMISSION, 1997, tradução nossa) ${ }^{11}$

Como resposta a essa nova arquitetura de segurança do pós Guerra Fria, houve, nos anos de 1990, o aumento da cooperação política europeia. Cabe ressaltar a assinatura do Tratado de Maastricht, em 1992. Ele institucionalizou as iniciativas que vinham sendo feitas na cooperação em segurança e defesa. O tratado criou uma Política Externa e de Segurança Comum do bloco (PESC) (COUNCIL OF THE EUROPEAN COMMUNITIES, 1992). Em junho do mesmo ano, foi feita a Declaração de Petersburgo que definiu que a União Europeia poderia acionar a União da Europa Ocidental para desenvolver operações militares em missões humanitárias de salvamento, missões de manutenção da paz, gestão de crises e pacificação (EUROPEAN FOREIGN POLICY UNIT, 2012).

Em 1996, houve o estabelecimento da Organização para Cooperação Conjunta em Matéria de Defesa (OCCAR - sigla em francês) entre França, Alemanha, Itália e Reino Unido (JONES, 2007). Ela estabeleceu o princípio do “retorno justo”. Esse princípio determinou que a indústria de defesa de cada país deveria receber um retorno de no mínimo $66 \%$ do valor que o governo daquele país investisse no programa conjunto. O princípio foi positivo no sentido de incentivo à divisão de custos entre os Estados membros, fomentando projetos que seriam muito custosos para um país sozinho realizar; mas resultou em ineficiência, pois cada nação ficava responsável por desenvolver e produzir certas partes de determinado programa conjunto. Recentemente, a OCCAR substituiu o sistema do retorno justo - com base em análises de cada programa - por um no qual há uma revisão anual da divisão de trabalho, o que torna as parcerias mais produtivas e duradouras (EDWARDS, 2011).

Em 1997, a Comissão Europeia produziu um documento sobre o setor de defesa europeu, conhecido como Relatório Bangemann (GREVI; KEOHANE, 2009). Esse relatório previa propostas para a criação de um mercado comum de armamentos (incluindo um sistema de licença para transferência de produtos de defesa internamente), a promoção de procedimentos de licitação pública

11 Do original em inglês: "The european defence-related industry is too fragmented to be sustainable. The sharp drop in demand following the end of the cold war, combined with fierce competition from newly created 'giant' corporations in the United States has put the future of this industry at stake” (EUROPEAN COMISSION, 1997). 
para aquisição de equipamentos de defesa e a eliminação de direitos aduaneiros sobre alguns produtos de defesa. Outras medidas sugeridas no relatório incluíam a alteração das regras de concorrência do bloco (para permitir que a Comissão Europeia fiscalizasse o comércio de todos os tipos de equipamento de defesa), padronização dos procedimentos de aquisição e o estabelecimento de competências claras para o uso dual pela Comissão Europeia (EUROPEAN COMMISSION, 1997).

No ano seguinte, França, Alemanha, Reino Unido, Suécia, Espanha e Itália assinaram uma Carta de Intenção (Letter of Intention - LoI) em que concordavam que os países deveriam harmonizar a operabilidade de seus armamentos a fim de diminuir a duplicação de capacidades e continuarem competitivos no sistema internacional (JONES, 2007). A LoI versava especificamente sobre a logística de defesa dentro do bloco europeu (EDWARDS, 2011) e serviu como um dos precedentes da atual Diretiva Europeia 2009/81/EC relativa a aquisições em segurança e defesa. Ela possuía sete princípios. Desses, conforme Edwards (2011), os mais relevantes são:

1) Segurança de abastecimento: o suprimento de armamentos e serviços de defesa deve ser mantido em tempos de paz e de guerra;

2) Exportação: a reestruturação da base industrial de defesa europeia não poderia trazer impeditivos à exportação de produtos e serviços de defesa dos países membros;

3) Segurança da informação: a segurança da informação deveria ser garantida sem impor restrições desnecessárias ao movimento de staffs, informações e material entre os países.

Em grande parte, como resposta à dependência de capacidades americanas para a realização das operações nos Balcãs, no ano 2000, a carta se transformou em um acordo. Após o desenvolvimento da primeira força militar com bandeira da União Europeia, em 2003 (MISSIROLI, 2003), ocorreu a criação da Agência Europeia de Armamento, em 2004. Ela tinha cinco funções relacionadas à busca por uma cadeia de suprimento europeia: desenvolver capacidades de defesa, promover pesquisa e tecnologia de defesa, fortalecer a base industrial e tecnológica de defesa, promover a cooperação em armamentos e criar um mercado competitivo europeu de equipamentos de defesa.

Em 2006, a agência lançou um código de conduta para aquisições em segurança e defesa (exceto para pesquisa e desenvolvimento), servindo de precedente para 
a Diretiva Única 2009/81/EC (UNIÃO EUROPEIA, 2009). O código previa que os países membros deveriam abrir para competição dos outros países membros todos os contratos acima de um milhão de euros enquadrados como itens não essenciais à defesa nacional ${ }^{12}$. Isso seria feito através de um sítio eletrônico que divulgaria os contratos em busca de possíveis fornecedores. Até 2011, 385 contratos haviam sido postos sob competição - um terço desses foi transfronteiriço (EDWARDS, 2011).

Outro precedente da Diretiva Única 2009/81/EC (UNIÃO EUROPEIA, 2009) que vale ser mencionado é a Diretiva do Setor Público 2004/18/EC (UNIÃO EUROPEIA, 2004). Ela versa sobre as aquisições do setor público em geral, mas não traz especificações sobre aquisições em segurança e defesa e, por isso, quando estava em vigor, não permitia que os Estados membros obtivessem do mercado interno legislação referente às aquisições da logística de defesa. Ela somente fomentava a utilização, pelo bloco, do Artigo $346^{13}$ do Tratado sobre o Funcionamento da União Europeia (TFUE).

\section{A Diretiva Europeia Relativa a Aquisições em Segurança e Defesa}

Visando prover uma legislação específica sobre aquisições em defesa, em 2009, após anos de preparação e discussão (com os esforços da OCCAR, da Agência de Defesa Europeia, da Comissão Europeia, da Carta de Intenção e sua posterior transformação em acordo), a Diretiva Única em Aquisições de Segurança e Defesa 2009/81/EC entrou em vigor juntamente com a Diretiva 2009/43/EC sobre transferência dentro da união de materiais de defesa e a declaração da Comissão Europeia sobre a "Estratégia para uma indústria de defesa europeia mais forte e competitiva" - chamados de Pacote de Defesa 2009 (EUROPEAN PARLIAMENT, 2015, p. 8). A Diretiva Única 2009/81/EC foi aprovada no Conselho da União Europeia em 2009 com 26 países a favor ${ }^{14}$, representando uma resposta (pelo menos dentro das instituições) às pressões sistêmicas de redução nos gastos de

\footnotetext{
12 Segundo a legislação da Diretiva Única 2009/81/EC, quatro tipos de armamentos podem ser enquadrados como sensíveis: armamentos e poder nuclear, sistema de armas complexo, sistemas de comunicação complexa, de detecção e sistemas furtivos (EDWARDS, 2011).

13 Conforme Edwards (2011, p. 8), o artigo 346 determina que: 1) as provisões da Diretiva não devem ser aplicadas quando o Estado membro considera a divulgação de informações contrárias aos interesses da segurança e defesa nacional; 2) qualquer Estado pode tomar as medidas necessárias para a proteção dos interesses essenciais da sua segurança que estejam ligadas com a produção ou comércio de armamentos militares.

14 Somente a Polônia se absteve; Croácia entraria no bloco apenas em 2013.
} 
defesa, aumento da fatia de mercado dos Estados Unidos e incerteza de possível auxílio americano em caso de necessidade (TRYBUS, 2014). Dessa forma, pode-se dizer que a Diretiva de Defesa resultou da adaptação da Diretiva do Setor Público 2004/18/EC, trazendo para dentro das instituições do bloco questões centrais para a logística de defesa, que vinham sendo discutidas dentro dos órgãos específicos (OCCAR e Agência Europeia de Armamentos) como a segurança de suprimento e da informação (TRYBUS, 2014). Conforme Trybus (2014), o objetivo da regulação europeia para aquisição em segurança e defesa é diminuir o protecionismo dentro do bloco a fim de promover uma cadeia de suprimento supranacional para evitar a duplicação de capacidades e o desperdício de recursos. Segundo o mesmo autor (2014), isso promoveria a utilização mais racional dos recursos escassos destinados à defesa para tornar os países europeus mais competitivos no mercado internacional de armamentos. Além disso, esperava-se que houvesse maior transparência nos contratos do setor e uma revisão das legislações nacionais a fim de se estabelecer um mercado interno para produtos e serviços de segurança e defesa (TRYBUS, 2014).

A Diretiva Única 2009/81/EC (UNIÃO EUROPEIA, 2009) regula os procedimentos da aquisição, as situações que ela pode ser utilizada, as condições de contrato, a qualificação dos licitantes, os critérios de seleção de um contratante, as compensações e subcontratos e a legislação para os concorrentes lesados (TRYBUS, $2014)^{15}$. Os atores que nela se enquadram são os governos centrais, regionais ou autoridades locais, corpos governados pela lei pública, associações formadas por uma ou mais dessas autoridades ou por um ou mais desses corpos (UNIÃO EUROPEIA, 2009). A Diretiva é aplicável à aquisição: i) de equipamentos militares e equipamentos sensíveis (incluindo suas partes, componentes e elementos de ligação); ii) obras e serviços diretamente relacionados a esses equipamentos em relação a um ou a todos os elementos de seu ciclo de vida; iii) obras e serviços para fins militares específicos, ou obras e serviços sensíveis. Seu escopo se delimita a contratos com valor estimado (sem o imposto sobre o valor acrescentado) igual ou superior a EUR 412.000 para os contratos de serviços e EUR 5.150.000 para os contratos de aquisição de obras e equipamentos (UNIÃO EUROPEIA, 2009).

Especificamente, os produtos que não entram na jurisdição da Diretiva 2009/81/EC (UNIÃO EUROPEIA, 2009) e que ainda não foram enquadrados nas

15 A literatura especializada em logística mostra que a governança da cadeia de suprimentos é elemento fundamental para a diminuição dos gastos de aquisição e manutenção dos sistemas de armamentos nacionais (RANDALL, 2013; RINDFIEISCH; HEIDE, 1997). 
definições acima são: i) os contratos relacionados a serviços de inteligência; ii) os contratos de pesquisa e desenvolvimento entre pelo menos dois Estados membros do bloco para desenvolvimento de um novo produto e para todo o ciclo de vida desse produto; iii) os contratos firmados com um terceiro país (inclusive para fins civis) quando as forças militares do bloco estão além-teatro e devem cumprir obrigações com operadores econômicos na zona de operações; iv) os contratos de locação ou aquisição de terrenos ou imóveis existentes; v) os serviços de arbitragem, conciliação e serviços financeiros (com exceção dos de seguros); vi) os contratos de trabalho e vii) os contratos entre dois governos para o fornecimento de equipamento militar ou de equipamento sensível ou obras e serviços diretamente ligados a esse equipamento (UNIÃO EUROPEIA, 2009). Percebe-se que não há clareza na definição do escopo da Diretiva e que há inúmeros caminhos para escapar de sua jurisdição.

Além disso, os países europeus podem invocar, na Corte de Justiça Europeia, o Artigo 346 do TFUE para evitar a utilização da Diretiva. Sublinha-se que a Diretiva Única 2009/81/EC (UNIÃO EUROPEIA, 2009) não subverte regras firmadas pelos países do bloco em organizações internacionais das quais façam parte, ou em acordos estabelecidos entre um ou mais Estados membros com um ou mais terceiros países relativos a armamentos e/ou posição de tropas (TRYBUS, 2014). Assim, a Diretiva não é aplicável nessas situações.

Percebe-se que a alternativa de utilização, por parte dos países, do artigo 346 do TFUE, representa uma possibilidade de os Estados escaparem dos objetivos da Diretiva de diminuição do protecionismo dentro do bloco. Os Estados membros da União Europeia se esforçam para demonstrar que as plataformas complexas, como carros blindados de combate, porta-aviões e caças de supremacia aérea, são integradas de tal forma que não podem ser separadas em contratos de diferentes níveis de segurança. Caberia à Comissão Europeia a discussão sobre a abertura de plataformas ou equipamentos não diretamente ligados àquelas três categorias, como veículos blindados de transporte, barcos de patrulha e sistemas de reabastecimento ar-ar (GREVI; KEOHANE, 2009).

A Diretiva Única 2009/81/EC (UNIÃO EUROPEIA, 2009) prevê que as entidades contratantes podem utilizar como padrão o procedimento por negociação com publicação prévia, o que lhes dá flexibilidade para ajustar todos os detalhes do contrato. Além disso, os candidatos à licitação são obrigados a apresentar garantias relativas à segurança das informações e à segurança de abastecimento. A Diretiva prevê também que os contratantes podem abrir as cadeias de suprimento 
para subcontratos de empresas de pequeno e médio porte (geralmente de países majoritariamente importadores de armamentos na União Europeia, como a Grécia). Ela determina também que as leis e decretos nacionais irão prover a legislação de proteção dos direitos das empresas que participem dos processos de licitação (EUROPEAN COMMISSION, 2016).

No que se refere ao investimento em pesquisa e desenvolvimento (P\&D), a Diretiva pretende encontrar um equilíbrio entre contratos desse tipo e a necessidade de abrir os mercados de produção para a criação de uma cadeia única de suprimentos na Europa. Por isso, ela fomenta a cooperação em pesquisa e desenvolvimento conjunto. Ademais, objetivando manter a capacidade de investimento estatal em P\&D, os projetos nacionais ficaram de fora da legislação comum. Entretanto, a Diretiva prevê que nas fases posteriores do ciclo de vida do produto, ${ }^{16}$ aqueles projetos devem ser abertos à competição europeia. Todavia, essa regra pode não gerar os efeitos esperados, uma vez que há a preocupação de que os Estados membros invistam em um projeto de P\&D e que as empresas da sua base nacional de defesa não vençam o contrato de fabricação (EDWARDS, 2011). Os mecanismos de compensações são enquadrados pela Comissão Europeia como uma prática que precisa ser erradicada, pois os procedimentos de aquisição em segurança e defesa deveriam ser abertos à competição, em que o elemento de decisão seja o preço e a qualidade do produto e não o valor das compensações que ele traz. Por isso, a Comissão Europeia determinou que utilizará o mecanismo de análise caso a caso para determinar a utilização do mecanismo de compensação (EDWARDS, 2011). Em março de 2013, todos os países da União Europeia haviam transpassado a Diretiva Única de Defesa 2009/81/EC (UNIÃO EUROPEIA, 2009) para suas legislações nacionais. Entre agosto de 2011 e março de 2013, 872 contratos foram firmados sob a jurisdição única, representando um total de EUR 1,77 bilhões (TRYBUS, 2014). O valor de quase dois anos de Diretiva é um sexto do orçamento destinado somente em 2007 para o setor, por exemplo. Em 2007 (um ano após a criação do código de conduta pela Agência Europeia de Armamento), os países europeus investiram aproximadamente EUR 32 bilhões em processos de aquisição em defesa, desses, EUR 6 bilhões em programas conjuntos (GREVI; KEOHANE, 2009).

Em 2016, a Diretiva 2009/81/EC foi revisada pelos países da União Europeia e não houve alterações em suas normas. Todavia, até aquele ano, somente $22 \%$

16 Aproximadamente, apenas $30 \%$ do investimento realizado em um sistema de armas é gasto na aquisição ou fabricação desse sistema. Os demais $70 \%$ são gastos na manutenção do sistema que tem o ciclo de vida médio em torno de 25-30 anos (GLAS; HOFMANN; EBIG, 2011). 
das aquisições de defesa dos Estados europeus se deu de forma colaborativa e aberta à livre concorrência. Esse fato reafirmou a duplicação de capacidades e a necessidade de o bloco rever as formas de reforçar a utilização da Diretiva 2009/81/EC (UNITED STATES, 2017).

\section{A Diretiva Única 2009/81/EC e o avião de transporte A400M Atlas}

Ainda há muito o que se fazer para reduzir a duplicação das capacidades europeias e melhorar os problemas de orçamento dos países. Todavia, há exemplos de projetos de cooperação que podem produzir efeito positivo na busca por uma maior cooperação em logística de defesa e, assim, manter a capacidade nacional de combate. É o caso do avião de transporte A400M Atlas.

Conforme anteriormente discutido, as operações nos conflitos de dissolução da antiga Iugoslávia demonstraram fragilidade dos europeus em capacidades estratégicas, dependendo de auxílio americano (JONES, 2007). Assim, Bélgica, França, Alemanha, Espanha, Turquia, Luxemburgo e Reino Unido (agrupados na OCCAR) assinaram um memorando em 2001 para a construção do avião de transporte europeu A400M. Eles visavam romper com a dependência do avião de transporte americano Hércules (JONES, 2007). Atualmente, o A400M é utilizado por França e Turquia nas operações no Afeganistão, Síria, Iraque, Mali, República Centro Africana e região do Sahel (AIRBUS, 2016).

A empresa Airbus (consórcio europeu) é a responsável pelo gerenciamento do projeto (AIRFORCE TECHNOLOGY, 2013) ${ }^{17}$. Em vista do incremento da capacidade autônoma europeia, em março de 2008, o primeiro ministro inglês Gordon Brown e o presidente francês Nicolas Sarkozy anunciaram que iriam criar um fundo para auxiliar no desenvolvimento de aeronaves que seriam utilizadas em operações multinacionais a âmbito da OTAN, União Europeia e Organização das Nações Unidas (ONU) (IISS, 2009). Sublinha-se que o projeto do A400M sofreu atrasos devido justamente a problemas com orçamento.

A primeira célula completa foi lançada em 2008 em Sevilha. Essa sofreu os impactos da crise de 2008 que atrasou o seu desenvolvimento e testes (IISS, 2009). Em janeiro de 2009, a EADS (que hoje faz parte do grupo Airbus) adiou os

17 O projeto A400M se insere na mudança estratégica, operacional e tática que ocorre na Europa desde o fim da Guerra Fria. O aumento da capacidade de projeção de poder para operações além-teatro (KING, 2011) também reflete as pressões americanas para divisão de custos na OTAN. 
primeiros pedidos do A400M para 2012. Em novembro de 2010, Alemanha, França, Reino Unido, Espanha, Turquia e Luxemburgo acordaram em destinar EUR 1,5 bilhões para que o programa continuasse. Todavia, devido a cortes nos orçamentos de defesa, Alemanha e Reino Unido diminuíram o número de aeronaves que iriam adquirir. Em 2013, as primeiras aeronaves foram entregues para a França. Todas as demais devem ser entregues até 2025 (AIRFORCE TECHNOLOGY, 2013). Atualmente, há 174 pedidos do avião; 26 foram entregues e estão em operação (AIRBUS, 2016).

O acordo de defesa assinado entre França e Reino Unido em 2010 (enquadrado pela literatura como Entente Frugale) previa o treinamento conjunto e suporte integrado dos aviões de transporte A400M dos dois países. Isso possibilitaria a redução de custos e impulsionaria uma maior cooperação em matéria de manutenção, logística e treinamento (UNITED KINGDOM, 2011). Essa intenção foi reafirmada em 2014 durante o encontro da RAF Brize Norton. Naquela data, ambos os países concordaram em padronizar determinações técnicas para o aumento da efetividade dos programas de intercâmbio para treinamento de pilotos e engenheiros britânicos no A400M antes da entrega da primeira aeronave inglesa (UNITED KINGDOM, 2014).

A característica tática e estratégica do A400M e seu propósito de construir uma capacidade autônoma europeia, bem como a intenção franco-inglesa de desenvolver interoperabilidade entre seus aviões, podem servir como primeiro movimento para a consecução de uma estrutura de desenvolvimento e uso conjunto militar na Europa.

\section{Conclusões}

Da análise dos precedentes e da Diretiva Única de Aquisição em Segurança e Defesa 2009/81/EC da União Europeia, percebe-se que seu desenvolvimento é fruto de uma reação dos países do bloco europeu à balança de ameaças do pós Guerra Fria. Ela é, portanto, reativa e não ativa às dinâmicas internacionais, levando a uma eficiência secundária, pois os países europeus invocam o Artigo 346 do TFUE para escapar da livre concorrência imposta pela Diretiva. Os primeiros passos para a construção de uma cadeia de suprimento logística em defesa supranacional foram dados, todavia, o processo esbarra em interesses securitários nacionais, demonstrando mais uma vez a centralidade do Estado nas ações relativas à 
logística de defesa que são críticas para a soberania estatal (RUSSEL, 2011) e a instrumentalidade da Diretiva pelos governos nacionais.

A amplitude do escopo da Diretiva 2009/81/EC, seus casos de exceção e a alternativa de acionar o Artigo 346 do TFUE em uma análise caso a caso representam mecanismos de fuga dos objetivos da jurisdição do bloco. Isso sem mencionar que a Diretiva não é aplicável quando há regras firmadas pelos países da UE em organizações internacionais das quais façam parte, ou em acordos estabelecidos entre eles com terceiros países (TRYBUS, 2014).

O uso da Diretiva somente para contratos que versam sobre questões não essenciais para os países continua mantendo a capacidade europeia fragmentada e duplicada (exemplo são os programas de veículos de combate blindados da União Europeia), impactando na sua posição no mercado de armamentos e na dependência dos países do bloco com terceiros países (GREVI; KEOHANE, 2009).

O protecionismo estatal ainda pressiona os países europeus a não cooperarem em projetos estratégicos, o que leva à duplicação das capacidades europeias e a uma competição delas no mercado internacional de armamentos (EDWARDS, 2011). A França, por exemplo, optou por não participar do consórcio entre Alemanha, Reino Unido, Itália e Espanha para construção do caça Eurofigther (EUROFIGTHER THYPOON, 2017). Em vez disso, o país continua o investimento em seu caça similar, Rafale. Devido ao princípio liberal de não permitir que os países façam contratos com base em compensações (como o uso de subcontratos locais, transferência de tecnologia etc.) e sim pelo preço e qualidade do produto, prevê-se a perda de capacidade industrial por parte dos países majoritariamente importadores de armamentos (como Finlândia, Grécia, Polônia, Portugal e Espanha) e uma especialização e beneficiamento dos países exportadores do bloco (como Alemanha, França e Reino Unido). Objetivando a diminuição das assimetrias entre os países e a diminuição da duplicação de capacidades, a Agência Europeia de Armamentos e a OCCAR devem fomentar a utilização, pelos países exportadores do bloco, da cadeia de suprimentos europeia, diminuindo a importação por parte desses países de armamentos americanos que incluem compensações indiretas (é o caso de Itália, Suécia, Holanda e Reino Unido) (EDWARDS, 2011).

A análise do supracitado fomento é tema para uma agenda futura de pesquisa; bem como a investigação sobre os impactos da "superposição" de estruturas e políticas multilaterais dentro do bloco europeu (OCCAR, OTAN, Agência Europeia de Armamentos etc.), que nem sempre englobam todos os países. Esse "embaralhamento" de organismos provoca complementaridade, 
incoerência ou duplicação de recursos e esforços institucionais? Por fim, resta o debate acerca da cooperação e da interdependência. Até que ponto a estrutura do sistema internacional e a pressão por autoajuda possibilitam confiança para a cooperação em temática tão sensível ao Estado nacional como o desenvolvimento de sistemas de armas (que envolve, em muitos casos, transferência de tecnologia e compartilhamento de dados sensíveis)?

\section{Referências}

AIRBUS. A400M: Delivery to the point of need. 2016. Disponível em: < https://airbusdefence andspace.com/our-portfolio/military-aircraft/a400m/ > . Acesso em: 30 ago. 2016. AIRFORCE TECHNOLOGY. A400M (Future Large Aircraft) Military Transport Aircraft. 2013. Disponível em: < http://www.airforce-technology.com/projects/fla/ > . Acesso em: 31 ago. 2016.

ALLISON, G. BREXIT: Defence ties 'not affected' say France. 2016. Disponível em: < https://ukdefencejournal.org.uk/brexit-defence-ties-not-affected-say-france/ > . Acesso em: 2 jul. 2016.

ALVES, V. C. História de um Envolvimento Forçado. São Paulo: Loyola, 2002.

BARDIN, L. Análisis de contenido. Madrid: Akal, 2002.

COUNCIL OF THE EUROPEAN COMMUNITIES. Commision of the European Communities. Treaty on European Union. Brussels; Luxembourg: Office for Official Publications of The European Communities, 1992. Disponível em: < http://europa.eu/eu-law/ decision-making/treaties/pdf/treaty_on_european_union/treaty_on_european_union_ en.pdf > . Acesso em: 09 jul. 2015.

CAVALCANTE, R. B.; CALIXTO, P.; PINHEIRO, M. M. K. Análise de Conteúdo: considerações gerais, relações com a pergunta de pesquisa, possibilidades e limitações do método. Inf. \& Soc, João Pessoa, v. 24, n. 1, jan/abr 2014, p.13-18.

DYSON, Tom. Neoclassical Realism and Defence Reform in Post-Cold War Europe. Basingstoke: Palgrave Macmillan, 2010.

EDWARDS, J. The EU Defence and Security Procurement Directive: A Step Towards Affordability? London: Chatham House, 2011. (International Security Programme Paper ISP PP 2011/05).

EUROFIGTHER THYPOON. How Eurofigther Typhoon Operates. 2017. Disponível em: < https://www.eurofighter.com/about-us > . Acesso em: 02 maio 2017.

EUROPEAN COMISSION. A Europe-wide market for defence products is vital if the industry is to survive. 1997. Disponível em: < http://europa.eu/rapid/press-release_IP-97983_en.htm >. Acesso em: 28 abr. 2017. 
EUROPEAN COMISSION. Defence procurement. 2016. Disponível em: < http://ec.europa. eu/growth/single-market/public-procurement/rules-implementation/defence/index_ en.htm > . Acesso em: 05 jun. 2016.

EUROPEAN FOREIGN POLICY UNIT. Chronology: The Evolution of a Common EU Foreign, Security and Defence Policy. Brussels: European Union, 2012. Disponível em: < http://www.lse.ac.uk/internationalRelations/centresandunits/EFPU/EFPUpdfs/ chronologyEUforpolinstitutions.pdf > . Acesso em: 17 ago. 2015.

EUROPEAN PARLIAMENT. The impact of the 'defence package' Directives on European defence. Brussels: European Union, 2015. Disponível em: < http://www.europarl. europa.eu/RegData/etudes/STUD/2015/549044/EXPO_STU(2015)549044_EN.pdf > . Acesso em: 19 jul. 2017.

EUROPEAN UNION. Diretivas da União Europeia. 2015. Disponível em: < http://eur-lex. europa.eu/legal-content/PT/TXT/?uri = LEGISSUM:114527 > . Acesso em: 19 jul. 2017. FLEURANT, A. et al. Trends in International Arms Transfers: 2016. Sipri Fact Sheet, Solna, v. 1, n. 1, fev. 2017, p.1-12. Disponível em: < https://www.sipri.org/sites/default/ files/Trends-in-international-arms-transfers-2016.pdf > . Acesso em: 28 abr. 2017.

GLAS, A.; HOFMANN, E; EBIG, M. Performance-based logistics: a portfolio for contracting military supply. International Journal of Physical Distribution \& Logistics Management, v. 43, n. 2, 2011, p. 97-115.

GOLDONI, L. R. F.; DOMINGOS NETO, M. Perspectivas da cooperação militar entre os BRICS. Tensões Mundiais, v. 10, n. 18, 19, jan./dez. 2014.

GREVI, G.; KEOHANE, D. ESDP resources. In GREVI, G; HELLY, D.; KEOHANE, D. European Security and Defence Policy: the first 10 years (1999-2009). Paris: European Union Institute for Security Studies, 2009. p. 69-114.

HOLTON, P. et al. Trends in International Arms Transfers, 2012. SIPRI Fact Sheet, SIPRI. Stockholm, mar. 2013. Disponível em: < http://www.sipri.org/publications > . Acesso em: 15 nov. 2013.

HOWORTH, Jolyon. Security and Defence Policy in the European Union. Hampshire: Palgrave Macmillan, 2007.

HURA, M. et al. Interoperability: A Continuing Challenge in Coalition Air Operations. Santa Monica: Rand, 2000.

JONES, S. G. The Rise of European Security Cooperation. Cambridge: Cambridge University Press, 2007.

KEOHANE, R. O; NYE, J. S. Power \& Interdependence. 4 ed. Longman. 2011.

KING, A. The Transformation of Europe's Armed Forces: from the Rhine to Afeghanistan. New York: Cambridge University Press, 2011.

KISTERSKY, L. New Dimensions of the International Security System after the Cold War. Stanford: Stanford University, 1996. Disponível em: < http://cisac.fsi.stanford.edu/ publications/new_dimensions_of_the_international_security_system_after_the_cold_ war > . Acesso em: 01 jul. 2015. 
LESKE, A. D. C. Inovação e Políticas da Indústria de Defesa. 2013; 197f. Tese (Doutorado em Economia) - Instituto de Economia da Universidade Federal do Rio de Janeiro, Rio de Janeiro, 2013.

MARKOWNSKI, S.; HALL, P.; WYLIE, R. (Eds.). Defence Procurement and Industry Policy: A small country perspective. London; New York: Routledge, 2010.

MEARSHEIMER, J. J. The False Promise of International Institutions. International Security, Harvard, v. 19, n. 3, 1995, p.5-49. Disponível em: < http://mearsheimer. uchicago.edu/pdfs/A0021.pdf > . Acesso em: 23 set. 2015.

MENDES, F. P. Lakatos, o Realismo Ofensivo e o Programa de Pesquisa Científico do Realismo Estrutural. 2013. 183 f. Tese (Doutorado) - Curso de Relações Internacionais, Instituto de Relações Internacionais, Universidade de São Paulo, São Paulo, 2013. Disponível em: < http://www.iri.usp.br/documentos/defesa_13-02-14_Flavio_ Pedroso_Mendes.pdf > . Acesso em: 14 mar. 2017.

MISSIROLI, A. (Comp.). From Copenhagen to Brussels: European Defence: core documents. 67. ed. Paris: Institute For Security Studies, 2003. Disponível em: < http://www.iss. europa.eu/uploads/media/cp067e.pdf > . Acesso em: 14 set. 2015.

MORGENTHAU, H. J. A política entre as nações: a luta pelo poder e pela paz. Brasília: Editora Universidade de Brasília, Instituto de Pesquisa de Relações Internacionais; São Paulo: Imprensa Oficial do Estado de São Paulo, 2003.

RANDALL, W. S. Are the Performance Based Logistics Prophets Using Science or Alchemy to Create Life-Cycle Affordability? - Using Theory to Predict the Efficacy of Performance Based Logistics. Defense ARJ, v. 20, n. 3, oct. 2013, p. 325-348.

RINDFLEISCH, A.; HEIDE, J. B. Transaction cost analysis: Past, present, and future applications. Journal of Marketing, v. 61, n. 4, 1997, p. 30-45.

ROSAMOND, Ben. Theories of European Integration. London: Palgrave Mcmillan, 2000.

RUSSELL, S. H. Supply chain management: more than integrated logistics. Air Force Journal of Logistics, v. 35, n. 3/4, 2011, p. 88-99.

RYNNING, Sten. Realism and the Common Security and Defence Policy. Journal of Common Market Studies, Oxford, v. 49, n. 1, jan. 2011, p.23-42.

SALES, R. D. Sistemas de Comando e Controle no Brasil - uma análise das contribuições do Exército Brasileiro. 2016. 164f. Dissertação (Mestrado em Ciências Militares) Programa de Pós-Graduação em Ciências Militares, Escola de Comando e EstadoMaior do Exército, Rio de Janeiro, 2016.

SILVA, G. C. Conjuntura Política Nacional: o Poder Executivo e Geopolítica do Brasil. 3. ed. Rio de Janeiro: J. Olympio, 1981.

SILVA, C. A. V; MUSETTI, M. A. Logísticas militar e empresarial: uma abordagem reflexiva. Revista de Administração, São Paulo, v. 38, n. 4, out./nov./dez. 2003, p. 343-354. 
STOCKHOLM INTERNATIONAL PEACE RESEARCH INSTITUTE (SIPRI). TIV of arms exports from the top 20 largest exporters 1989-2016. Disponível em: < http://armstrade. sipri.org/armstrade/page/toplist.php > . Acesso em: 28 abr. 2017.

STOCKHOLM INTERNATIONAL PEACE RESEARCH INSTITUTE (SIPRI). Military expenditure database, 2016. Disponível em < http://www.sipri.org/databases /milex > Acesso em: 04 outubro 2016.

THE INTERNATIONAL INSTITUTE FOR STRATEGIC STUDIES - IISS. The Military Balance 2009: the annual assessment of global military capabilities and defence economics. New York, 2009.

TRYBUS, M. Buying Defence and Security in Europe: The EU Defence and Security Procurement Directive in Context. Cambridge: Cambridge University Press, 2014.

UNIÃO EUROPEIA. Constituição (2004). Diretiva n ${ }^{0}$ 18, de 31 de março de 2004. Directiva 2004/18/CE do Parlamento Europeu e do Conselho: relativa à coordenação dos processos de adjudicação de determinados contratos de empreitada de obras públicas, dos contratos públicos de fornecimento e dos contratos públicos de serviços. Disponível em: < http://eur-lex.europa.eu/legal-content/PT/TXT/?uri = celex\%3A32004L0018 > . Acesso em: 19 set. 2017.

UNIÃO EUROPEIA. Constituição (2009). Diretiva nº 81, de 13 de julho de 2009. Directiva 2009/81/ce do Parlamento Europeu e do Conselho: relativa à coordenação dos processos de adjudicação de determinados contratos de empreitada, contratos de fornecimento e contratos de serviços por autoridades ou entidades adjudicantes nos domínios da defesa e da segurança, e que altera as Directivas 2004/17/CE e 2004/18/CE. Disponível em: < http://eur-lex.europa.eu/legal-content/PT/TXT/ PDF/?uri = CELEX:32009L0081\&from $=\mathrm{EN}>$. Acesso em: 03 jun. 2016.

UNITED KINGDOM. Ministry of Defence. UK and France strengthen defence cooperation. London: Ministry of Defence, 2014. Disponível em: < https://www.gov. uk/government/news/uk-and-france-strengthen-defence-co-operation $>$. Acesso em: 14 out. 2015.

UNITED KINGDOM. UK-France Summit 2010 Declaration on Defence and Security Co-operation. London: Crown Copyright, 2011. Disponível em: < https://www.gov.uk/ government/news/uk-france-summit-2010-declaration-on-defence-and-security-cooperation > . Acesso em: 23 jun. 2015.

UNITED STATES. Export.Gov. Security \& Defense Sector. 2017. Disponível em: < http://2016. export.gov/europeanunion/marketresearch/securityanddefensesector/index.asp > . Acesso em: 02 maio 2017.

VENESSON, Pascal; WIESNER, Ina. Process Tracing in Case Studies. In: SOETERS, Joseph; SHIELDS, Patricia; RIETJENS, Sebaastian (Eds.). Routledge Handbook of Research Methods in Military Studies. London: Routledge, 2014, p. 90-101. 
WALTZ, Kenneth N. Strutural Realism after the Cold War. IN: International Security, Vol. 25, No. 1, Summer 2000, pp. 5-41.

WALTZ, Kenneth N. Teoria das Relações Internacionais. Lisboa: Gradiva, 2002.

WALT, Stephen. Origins of Alliances. Ithaca: Cornell University Press, 1987.

WENDT, Alexander. Anarchy is what States Make of it: The Social Construction of Power Politics. International Organization, Vol. 46, No. 2, Spring, 1992.

YANG, H. et al. Arms or butter: The economic effect of an increase in military expenditure. Journal of Policy Modeling. ScienceDirect. Technology Management, Economics and Policy Program, Seoul National University, Republic of Korea. 2015. 


\title{
Barack Obama e o Oriente Médio: Um Panorama Crítico (2009/2017) ${ }^{1}$ \\ Barack Obama and the Middle East: A Critical Overview (2009/2017)
}

\author{
DOI: $10.21530 /$ ci.v12n2.2017.656
}

Cristina Soreanu Pecequilo²

Clarissa Nascimento Forner ${ }^{3}$

\section{Resumo}

O objetivo deste artigo é apresentar um panorama crítico da gestão de Barack Obama de 2009 a 2017 em relação ao Oriente Médio, analisando os cenários estratégicos da região e as implicações para a Eurásia das ações estadunidenses. Para sustentar sua análise, o texto apresenta a trajetória do governo democrata, tendo como base um estudo sobre o legado de seu antecessor, George W. Bush, entre 2001 e 2009. Os principais temas abordados referem-se aos impactos dos atentados terroristas de 11/09/2001, com foco nas guerras do Afeganistão (2001/2014) e do Iraque (2003/2011), o processo de paz Israel-Palestina, as relações com o Irã, a Primavera Árabe, as crises na Síria e Líbia e a ascensão do Estado Islâmico. Observa-se a continuidade de um padrão de instabilidade regional e ambiguidade da estratégia dos Estados Unidos, assim como variações táticas entre as administrações republicana e democrata para a projeção de poder nesse espaço geopolítico e geoeconômico, que permanece essencial para os interesses do país.

Palavras-chave: Barack Obama; George W. Bush; Oriente Médio; Política Externa dos Estados Unidos

1 O artigo resulta de pesquisas desenvolvidas com apoio do CNPq e da CAPES.

2 Departamento de Relações Internacionais da Universidade Federal de São Paulo, em São Paulo/SP, Programa de Pós-Graduação em Relações Internacionais San Tiago Dantas (UNESP/UNICAMP/PUC), São Paulo/SP, Brasil, do Programa de Pós-Graduação em Economia Política Internacional/UFRJ, Rio de Janeiro/RJ, Brasil, e Pesquisadora NERINT/UFRGS, Porto Alegre/ RS, Brasil. E-mail: crispece@gmail.com

3 Bacharel em Relações Internacionais da Universidade Federal de São Paulo, em São Paulo/SP Programa de Pós-Graduação em Relações Internacionais San Tiago Dantas (UNESP/UNICAMP/PUC), São Paulo/SP, Brasil, Pesquisadora GEDES/UNESP e NEAI/UNESP, São Paulo/SP, Brasil.

Artigo submetido em 04/03/2017 e aprovado em 22/05/2017. 


\begin{abstract}
The goal of this article is to present a critical overview of Barack Obama's term from 2009 till 2017 in the Middle East, by analyzing the strategic scenarios of the region and the implications of US actions in Eurasia. In order to develop this analysis, the text presents the trajectory of the democratic government, by previously studying his predecessor legacy, George W. Bush from 2001 till 2009. The main issues addressed in this essay are the impacts of $9 / 11$ attacks, focusing on the Afghanistan (2001/2014) and Iraq (2003/2011) wars, the Arab Spring and the crisis in Syria and Lybia and the emergence of the Islamic State. A recurring pattern of regional instability can be seen, as well as the ambiguous strategy presented by the United States, as well as tactical variations between the republican and democratic administrations for projecting power in this geopolitical and geoeconomic space that remains pivot to the country's interests.
\end{abstract}

Keywords: Barack Obama; George W. Bush; Middle East; US Foreign Policy

\title{
Introdução
}

Geopolítica e geoeconomicamente, o Oriente Médio é uma das regiões mais sensíveis para os Estados Unidos (EUA), por sua localização geográfica, a sobreposição e reconstrução de fronteiras herdadas da era colonial, a competição entre potências estrangeiras extrarregionais por seus recursos energéticos e rotas de passagem e o reequilíbrio intrarregional entre poderes locais em busca de soberania e autonomia. Os norte-americanos alternaram ações de intervenção militar direta, ingerência político-econômica e esforços diplomáticos para projetar poder e estabelecer um mapa estratégico favorável à hegemonia.

Tais ações corresponderam a oscilações táticas, caracterizadas ou pela negligência e distanciamento ou pelo ativismo. No século XXI, tal situação foi agravada pelos atentados terroristas de 11/09/2001 aos EUA, atribuídos à Al-Qaeda, liderada por Osama Bin Laden. Em resposta, o republicano neoconservador ${ }^{4}$ George W. Bush desencadeou, em novembro daquele ano, a primeira operação militar da Guerra Global Contra o Terror (GWT) no Afeganistão, Estado identificado como

4 De acordo com Cooper (2011) e Singh (2009) não faltam dificuldades metodológicas ou consenso na definição do termo e agenda neoconservadora. A promoção da democracia, o internacionalismo unilateral e militarista fazem parte desses preceitos. Segundo os autores, ainda que W. Bush não tenha cumprido plenamente essa pauta, sua administração pode ser definida como neoconservadora, opção aqui compartilhada. Não é propósito do artigo analisar o termo neoconservador, recomendando-se Teixeira, 2007. 
santuário do terrorismo fundamentalista. Essa operação foi apenas o primeiro passo de transformações significativas no Oriente Médio e seu entorno.

Para os EUA, as consequências foram a superextensão imperial, crise econômica, fragmentações internas e perda de poder relativo ${ }^{5}$. Como sustenta Brzezinski (2012),

(...) a administração Bush demonstrou pouco interesse pelos cenários culturais complexos, rivalidades étnicas profundamente enraizadas, gerando conflitos dentro de conflitos, vizinhanças regionais perigosamente instáveis (...) e as disputas territoriais não resolvidas, todas as quais que severamente complicara as ações dos Estados Unidos no Afeganistão e Iraque e despertaram paixões anti-americanas regionais mais amplas (...) as consequências foram um declínio dramático na posição global da América (...) e (...) um resultado mais provável pode implicar um período inconclusivo de crise doméstica, combinada com a decadência abrangente da qualidade de vida na América, a infraestrutura nacional, a competitividade econômica e o bem estar social. (BRZEZINSKI, 2012, p. 67, 70, 73) ${ }^{6}$

Em 2009, tais fatores contribuíram para a eleição do primeiro presidente negro dos EUA, o democrata Barack Obama. Obama, cuja trajetória política caracterizou-se pela oposição a W. Bush, trouxe as propostas da mudança e da esperança. Isso se traduzia nas promessas de recuperação da economia, na inclusão social e na revisão das políticas unilaterais e militaristas de seu antecessor. Obama conseguiu cumprir tal agenda? Como lidou com o legado W. Bush? O objetivo do artigo não é trazer uma análise exaustiva da gestão Obama, mas sim um recorte: o estudo da agenda para o Oriente Médio. O texto encontra-se organizado em duas partes, uma síntese do legado W. Bush, seguida pela agenda de Barack Obama.

5 O conceito de superextensão imperial baseia-se em Kennedy (1989) e se refere ao descolamento entre as capacidades econômicas, político-estratégicas hegemônicas e a expansão de responsabilidades globais. A era W. Bush é apontada como uma das de maior endividamento financeiro e equívocos por analistas como Kissinger, 2014, Brzezinski, 2012 e Bandeira, 2016.

6 (...) the Bush administration showed little regard for the complex cultural settings, deeply rooted ethnic rivalries generating conflicts within conflicts, dangerously unsettled regional neighborhoods (...) and the unresolved territorial disputes, all of which severely complicated US actions in Afghanistan and Iraq and ignited wider regional anti-America passions (...) The consequences were a dramatic decline in America's global standing (...) one (...) more likely outcome could involve a period of inconclusive domestic drift, combining spreading decay in America's quality of life, national infrastructure, economic competitiveness, and social well-being (BRZEZINSKI, 2012, p. 67, 70, 73) 


\section{O Legado W. Bush: 0 11/09 e a GWT $(2001 / 2009)^{7}$}

Ao longo dos dois mandatos de W. Bush, poucas regiões foram tão afetadas política, econômica e socialmente quanto o Oriente Médio, devido à escalada acelerada da militarização e envolvimento norte-americano, justificada pelos atentados de 11/09 e a GWT. Segundo Gottlieb (2012), a GWT sustentou-se em quatro pilares: a diplomacia, a aplicação da lei contra os acusados de terrorismo, a força militar e os mecanismos econômicos (embargos, sanções e controles financeiros). Como sustenta Kitchen (2017), a GWT é multidimensional, e tanto W. Bush quanto Obama alternaram opções geopolíticas e geoeconômicas. Para o autor, não é possível afirmar que a geoeconomia se sobrepôs à geopolítica, sendo um dos instrumentos da GWT e não o preferencial. Ainda que tal projeção não fosse inédita, o período pós 2001 intensificou a ingerência com duas guerras: Afeganistão (2001/2014) e Iraque (2003/2011).

\section{o Terrorismo Transnacional e a Guerra Justa}

Sustentadas pela justificativa de combater o terrorismo islâmico transnacional, Iraque e Afeganistão inseriram-se em um processo de reposicionamento estratégico na Eurásia, considerada prioritária pelos neoconservadores desde 1989. O fim da Guerra Fria representava uma oportunidade de reconfigurar o mapa regional de forma mais favorável aos interesses dos EUA no Oriente Médio e na Ásia Central, em particular nesse último espaço, devido ao vácuo gerado pela antiga União Soviética (URSS).

A operação Tempestade do Deserto, a Guerra do Iraque (1990/1991), foi percebida como o primeiro passo nessa trajetória, e essas orientações foram previstas no Defense Planning Guidance (1992). Todavia, as ações do presidente George H. Bush, pai de W. Bush, caminharam no sentido contrário. O objetivo foi o de manter o status quo: o Iraque teve a sua soberania mantida, com o governo de Saddam Hussein, que nos anos 1980 aliara-se a Washington para combater a Revolução Islâmica de 1979 no Irã, e somente passara a ser inimigo devido à invasão do Kuwait para controlar as reservas de petróleo regionais. A saída de Hussein era vista como arriscada, pois geraria vácuos de poder. O mesmo raciocínio foi aplicado às relações com o Irã, a Síria, a Líbia, o Egito e as petromonarquias do Golfo Pérsico.

7 Ver Pecequilo, 2013. 
Embora Iraque, Irã, Líbia e Síria fossem definidas como "nações bandidas" (rogue states ${ }^{8}$ ), governadas por regimes autoritários, de caráter agressivo e com pretensões hegemônicas, com investimentos em programas de armas de destruição em massa e sem respeitar as convenções internacionais, as pressões mantinham-se no campo político. Tal estratégia permaneceu no governo de Bill Clinton (1993/2000), que alternou essa visão de continuidade com esforços de engajamento e contenção de Irã e Iraque.

No caso do Irã, uma tentativa de descongelamento foi realizada a partir de 1997, com a ascensão de Mohammad Khatami ao poder (SELIKTAR, 2012). No Iraque, manteve-se uma política de pressão com bombardeios aéreos sistemáticos e a aplicação de sanções político-econômicas. Ambas as políticas, guardadas suas diferenças, eram consideradas de apaziguamento pelos neoconservadores, e foram criticadas por W. Bush desde sua campanha eleitoral em 2000. Mesmo antes de 11/09, as duas opções já haviam sido abandonadas.

A mudança significativa aplicou-se ao processo de paz Israel-Palestina que, nos anos de 1980, entrara em uma fase de estagnação e retrocesso. Em choque com os interesses neoconservadores e do lobby israelense, Bush pai impulsionou uma solução negociada que retomava a agenda diplomática implementada (e depois abandonada) pelos EUA nos anos 1970: a troca da terra pela paz mediada pelos norte-americanos, com a devolução, por Israel, de territórios ocupados, e o reconhecimento da soberania desse Estado pelo interlocutor. Tal modelo de negociações resultara nos Acordos de Camp David entre Israel e Egito, em 1979, marco da estabilidade regional.

No pós Guerra Fria, a experiência repetiu-se com os Acordos de Oslo de 1993, implementados após um ciclo de negociações secretas em Madri, 1991. Iniciou-se um processo gradual de devolução de terras à Palestina e a suspensão da construção de colônias israelenses (Cisjordânia e Faixa de Gaza), a criação da Autoridade Nacional Palestina (ANP) como embrião do Estado palestino, conforme estabelecido pela resolução original das Nações Unidas de 1948, e o reconhecimento de Israel como Estado pelos palestinos. À frente do processo, estiveram H. Bush e depois Clinton, Ytzhak Rabin e Shimon Peres, por Israel, e Yasser Arafat, pela Palestina.

8 A outra categoria era nações falidas (failed states), desorganizadas politicamente, caracterizadas por guerras internas e potenciais santuários para ações terroristas (Afeganistão, Haiti, Somália). A partir de 2016, ambas as classificações de nações falidas e bandidas vêm sendo substituídas por "nações frágeis" (fragile states). Ver o Fragile States Index (2016) disponível em: < http://fsi.fundforpeace.org/ > . Acesso em: 20 fev. 2017.

9 Recomenda-se Visentini, 2014. 
De 1993 a 1995, o processo avançou, mas desmontou-se com o assassinato de Rabin por um radical israelense.

Em Israel, isso favoreceu a volta dos conservadores ao poder com Benjamin Nethanyahu (Bibi) ${ }^{10}$ (1996/1999). Tentativas de retomar o processo, como os Acordos de Wye Plantation (1998), não obtiveram sucesso e os atentados de 11/09 e a ascensão de W. Bush colocaram em xeque qualquer alternativa mediada. Essa estagnação foi mais um dos fatores da desorganização do Oriente Médio, ao qual se somaram a crescente violência, a instabilidade dos regimes, a ausência de desenvolvimento econômico e a exclusão social.

Ainda que muitos desses componentes fossem recorrentes pré 2001, a aceleração dos fenômenos foi resultado da projeção de poder dos EUA e levou à fragmentação de estruturas de poder, sociais e econômicas. 0 11/09 funcionou como uma válvula de escape para justificar as ações neoconservadoras e reativou a hipótese do choque civilizacional entre o Ocidente e o mundo islâmico, cujo embrião está na década de 1980 (BANDEIRA, 2016). Desde 1979, com a Revolução do Irã, mesmo antes da análise de Huntington que sistematizou o Choque das Civilizações, os EUA e a Europa Ocidental viram-se confrontadas pela “onda verde”, conhecida como a expansão do fundamentalismo islâmico (HALLIDAY, 2005) .

Entre 2001/2002 foram criados o Departamento de Segurança Doméstica (DHS) e o Comando Militar do Norte (USNORTHCOM), como parte do combate ao terrorismo, e foi editado o Ato Patriota (USA Patriot Act). Lei federal, o Ato Patriota validava medidas de exceção, como a prisão sem justificativa de suspeitos de terrorismo, a prática de tortura nas prisões militares do Iraque (Abu-Graib) e na base de Guantánamo. Havia crescente tolerância da população a tais práticas devido ao medo, o que somente alimentou globalmente comportamentos de extremo nacionalismo, racismo e xenofobia.

Para Daalder e Lindsay (2003), essas guerras faziam parte de uma agenda estratégica dos neoconservadores, que previa uma sequência de operações militares para consolidar o processo de mudança de regime nas potências não aliadas, visando o controle da Eurásia. O Afeganistão era o primeiro passo para tal domínio, mas que esbarrou nas dificuldades das operações em solo, na incapacidade dos EUA de implementar governos favoráveis à sua agenda, na resistência local e na triangulação sino-russo-indiana. O ponto de inflexão foi o fracasso no Iraque e o prolongamento de ambas as operações, que levou ao esgotamento moral, social e financeiro das tropas, forçando os neoconservadores a abandonar o plano de

10 Nethanyahu volta ao poder em 2009. 
intervenções sequenciais. Uma nova ação ocorreria somente na Líbia, em 2011.

Definida como "Guerra Justa", a guerra do Afeganistão representou o primeiro movimento militar da GWT. Vista como uma resposta à agressão de 11/09, conduzida pela Al-Qaeda, liderada por Bin Laden, que se encontrava protegido em solo afegão pelo governo dos Talibãs, a operação foi apoiada pela comunidade internacional. Sob o nome de "Operação Liberdade Duradoura", a ação foi referendada pela Resolução 1386 das Nações Unidas e contou com o auxílio financeiro, logístico e humano da Organização do Tratado do Atlântico Norte na forma da ISAF (International Security Assistance Force).

Em termos militares, a operação foi declarada bem-sucedida, ainda que as tropas da OTAN não tenham conseguido capturar Bin Laden ou as principais lideranças da Al-Qaeda. Isso levou à ampliação não oficial do conflito para a fronteira com o Paquistão, que se tornou um novo refúgio de forças fundamentalistas. O que ficou aparente não foi o cenário de fragmentação, e sim o sucesso político-militar. Entre 2002-2004 o país realizou eleições, levando Hamid Karzai ao poder, aliado do ocidente, seguidas pela implementação da Constituição, em 2005. Entretanto, tal processo de mudança de regime estava longe de estabilizar o país e de garantir direitos iguais a todos os cidadãos, especialmente às mulheres. Essas dificuldades eram acentuadas pela crescente instabilidade no Iraque (operação iniciada em 2003) e o aumento da insegurança no Ocidente, com os atentados de Madrid e Londres, em 2004 e 2005, que jogavam a opinião pública contra as operações militares.

Em 2006, a contínua deterioração da situação levou W. Bush a aumentar o número de soldados norte-americanos no Afeganistão. Os primeiros sinais da crise econômica, que eclodiria entre 2007/2008, levaram à derrota dos republicanos nas eleições de meio de mandato de 2006, e a crescentes pressões para que se estabelecesse um cronograma de retirada das tropas desse país e do Iraque. Mas como se chegou à Guerra do Iraque em 2003 e às demais crises?

\section{O Mapa da Estrada, o Eixo do Mal e a Guerra Preventiva}

Retomando a trajetória W. Bush, no caso do processo de paz, o mesmo representou a validação das posturas neoconservadoras em Israel, com Ariel Sharon ${ }^{11}$ à frente do governo entre 2001/2006 (seguido por Ehud Olmert de 2006 a 2008), devido à política pró Israel. Durante o governo Sharon, destacaram-se

11 Sharon foi acusado de liderar operações militares que resultaram em massacres de civis em Qybia (1953) e Sabra e Shatila (1982). Em 2000, sua visita à Esplanada das Mesquitas, local sagrado para os muçulmanos, iniciou uma forte onda de violência interna, e favoreceu o avanço conservador nas eleições em Israel. 
iniciativas como a construção do muro na fronteira (o "Muro Protetor"), a aceleração dos assentamentos nos territórios ocupados e a repressão sistemática à população palestina, com a tolerância do governo norte-americano (e as conhecidas condenações das Nações Unidas e internacionais). Em 2002, essa situação pareceu mudar: em meio à crescente violência e às pressões da comunidade internacional, instalou-se o Quarteto de Madrid, por meio do qual os EUA, a União Europeia, a Rússia e as Nações Unidas visavam retomar as negociações do processo de paz.

O Mapa da Estrada (Road Map) retomava a agenda de construção dos dois Estados, Israel e Palestina, propunha cessar fogo entre as partes, a devolução de territórios e a suspensão dos assentamentos de colonos. O projeto não alcançou nenhum resultado concreto. Outros fatos, que colocaram em xeque a agenda da paz, foram a morte de Yasser Arafat em 2004 (sucedido por Mahamud Abbas desde 2005) e o crescimento da influência política de grupos radicais como o Hamas. A vitória do Hamas em eleições na ANP, enfraquecendo o poder de Abbas, favoreceu as forças neoconservadoras em Israel e nos EUA, cuja política era a de não negociar com terroristas. Em linhas gerais, isso facilitou a destruição sistemática da ANP, situação que não se alterou na gestão de Obama.

Em 2002, essa iniciativa contrastava com a retórica agressiva de Bush com o lançamento do "Eixo do Mal”, que agrupava "Estados bandidos" que ameaçavam a sobrevivência norte-americana: Irã, Iraque e Coreia do Norte, seguidos por Líbia, Síria e Cuba. Apesar de nenhum representar um risco sistêmico, o clima de medo favorecia a construção de ameaças e de justificativas para intervenções militares. Nesse mesmo ano, foi lançada a Doutrina Bush, a Estratégia de Segurança Nacional (NSS) preventiva, que previa o ataque a alvos que ameaçassem a segurança norte-americana antes que essas nações se constituíssem em riscos iminentes. A NSS foi implementada na prática com a Guerra do Iraque. A despeito da oposição da comunidade internacional (com destaque ao "Eixo da Paz", formado por Moscou, Berlim, Paris), o Iraque foi atacado pelas forças norte-americanas, liderando a "Coalizão da Vontade".

A trajetória desse conflito demonstrou-se bastante controversa, com os EUA alegando que o país governado por Saddam Hussein era um risco. Todavia, nem aliados, e nem as Nações Unidas, validaram tal posição. Essa guerra não foi autorizada pelas Nações Unidas, apesar da existência da resolução 1441, que estabelecia que o Iraque sofreria "sérias consequências" em caso de não cumprir os mandatos da organização. Solidificava-se o exemplo de uma ação preventiva e unilateral, sendo o apoio mais significativo o do Reino Unido, liderado pelo 
primeiro-ministro Tony Blair. Posteriormente, W. Bush e Blair admitiram que os dados apresentados para sustentar a operação eram falsos, principalmente no que se refere à posse de armas de destruição em massa pelo Iraque.

A partir da guerra, o Iraque tornou-se um país cada vez mais fragmentado. Como no caso do Afeganistão, a vitória militar rápida, a captura em 2003 e o falecimento de Saddam Hussein em 2006, após sua condenação à morte pela justiça, não garantiram uma transição pacífica. Muito pelo contrário, realizaram-se, como indicam Daalder e Lindsay (2003), as avaliações do Departamento de Estado, que haviam impedido a derrubada de Hussein em 1991, e que foram retomadas antes da invasão de 2003: vácuo de poder, ampliando disputas internas pelo controle político do território.

Essa situação foi subestimada pelo governo W. Bush, que diminuiu as tropas após a primeira fase da operação “Choque e Terror” (Shock and Awe). Em 2006, isso levou a uma ofensiva militar (surge), seguido pelo início do desengajamento. Em 2008, foi assinado o Status of Forces Agreement, por W. Bush e o premiê Nouri al-Maliki, prevendo a retirada das tropas americanas do território até 2011. Seguindo o cronograma, a retirada parcial foi anunciada em 2010, com a manutenção de 50 mil homens em campo. Residualmente, as forças especiais, responsáveis por covert actions do Departamento de Defesa e da Central de Inteligência Americana (CIA), bem como as tropas mercenárias, financiadas por companhias privadas de segurança, continuaram atuando. A insuficiência desses esforços pós 2011, associada à fragmentação prévia, forneceram condições para a expansão do Estado Islâmico (EI).

Não se pode encerrar essa análise sem mencionar a política de estrangulamento contra o Irã, que resultou na aceleração do programa nuclear, associada à volta dos conservadores religiosos ao poder com Mahmoud Ahmadinejad, em 2005. De acordo com Kissinger (2014), esse processo deve ser encarado com normalidade, uma vez que é produto das pressões externas ao regime, ameaçando sua soberania e segurança. Como indica Waltz (2012), a “bomba iraniana” deveria ser compreendida como um fator muito mais de estabilidade do que de crise, pois reforça o poder de barganha do país e o equilíbrio regional ${ }^{12}$.

Como parte do processo, foram assinados acordos bilaterais com a Rússia no campo nuclear e se buscou reforçar uma agenda alternativa de relações internacionais com nações como a Venezuela, que se opunham a W. Bush. A questão

12 Tática similar é utilizada pela Coreia do Norte. 
nuclear iraniana, em 2010 e 2015, se tornaria um marco da gestão Obama. Em síntese, o legado W. Bush para o Oriente Médio preparou o terreno para muitos dos fenômenos e problemas que Obama precisaria administrar.

\section{A Gestão Obama: Da Ofensiva à Paciência Estratégica (2009/2017)}

A trajetória política de Barack Obama não pode ser descolada de seu discurso crítico aos efeitos que a GWT trouxera para os EUA: desrespeito aos direitos humanos, com apoio à tortura e práticas de exceção, como espionagem de cidadãos. Até a candidatura presidencial, Obama construiu sua plataforma em torno de ataques veementes a essa agenda, que depois assumiram um tom mais pragmático, centrado na promessa de encerrar a GWT e recuperar credibilidade. Tal credibilidade seria retomada por meio da reaproximação com os aliados, o apoio ao multilateralismo e aos esforços cooperativos para lidar com temas de segurança, assim como a atenção a questões sociais internas e da agenda global, tais quais direitos humanos e meio ambiente.

Essa análise não é consensual: de acordo com Kitchen (2017), o foco das críticas de Obama não era a GWT em si, mas somente a Guerra do Iraque, "contrasting the dumb war in Iraq, with the necessary war in Afghanistan" (KITCHEN, 2017). Outras oposições que se naturalizaram para definir ambas as guerras foram "war of choice" (guerra de escolha) para o Iraque, "war of need" para o Afeganistão, e a comparação entre as duas guerras do Iraque de 1991 e 2003, respectivamente de necessidade e escolha, conforme a leitura de Haas (2009).

Quinn (2017), em visão compartilhada por esse artigo, considera limitado afirmar que Obama apenas tinha como preocupação reafirmar sua posição contra o conflito no Iraque, e não o escopo da GWT. Segundo o autor,

Ele criticou a natureza aparentemente sem fim da "Guerra Contra o Terror" como uma estrutura legal e ideológica com base no fato de que ela conferia à presidência uma autoridade ampla e sem controle para o uso da força e a coleta de informações (...) Ele também criticou a administração por ter esvaziado o estoque de boa vontade internacional direcionada aos Estados Unidos devido sua tendência à confrontação e ao unilateralismo. (QUINN, 2017)13

13 He criticized the apparently open-ended nature of the "War on Terror" as a legal and ideological framework on the grounds that it conferred broad and unchecked authority on the presidency in the use of force and gathering of intelligence (...) And he chided the administration for having depleted the stock of international goodwill towards the United States through its penchant for confrontation and unilateralism. (QUINN, 2017) 
Apesar do apelo que tais questões tiveram em 2008, não foi essa agenda externa que garantiu a vitória eleitoral, e sim as consequências da crise econômica, que levaram o país à recessão. O empobrecimento e o desemprego e os rachas sociais raciais, étnicos e religiosos eram apenas alguns componentes desse cenário. Sustentado por sua juventude e figura carismática, e atrelado à imagem de "cidadão do mundo" e representante de uma América multirracial, Obama chegou à Casa Branca.

Em 2009, uma das principais preocupações foi promover uma mudança na retórica e no discurso de W. Bush, no qual se destacou o uso do termo "Poder Inteligente" (Smart Power). Criado por Joseph S. Nye Jr (2011), teórico que havia estabelecido as classificações de "Poder Duro" (Hard Power) e "Poder Brando" (Soft Power), nos anos de 1990, a ideia desse conceito era contrapor o estilo de Obama ao de seu antecessor: os EUA exerceriam uma liderança cooperativa, equilibrando força militar, ideológica e institucional. De acordo com Traub (2015) e Kitchen (2017), o termo, e a prática do conceito, tornaram-se usuais no governo Obama, tanto pelo presidente como pela secretária de Estado Hillary Clinton (2009/2013).

O uso do conceito representava uma iniciativa de reforço do poder ideológico ${ }^{14}$, ainda que não fosse um “documento oficial” estratégico. Em termos práticos, os primeiros documentos formais da "Doutrina Obama” foram apresentados em 2010, como indica Peter Dombrovsky (2012): o Quaddrennial Defense Review (QDR), a Nuclear Posture Review (NPT) e a Estratégia de Segurança Nacional (THE WHITE HOUSE, 2010).

Movido pelo contexto de deterioração da economia, Obama direcionou as energias do primeiro ano de governo à conclusão das intervenções no Oriente Médio. O presidente declarou o encerramento oficial da GWT, alterando a nomenclatura das operações a ela relacionadas para Overseas Contingency Operations. Como indicam Jackson e Tsui (2017), Obama passou a usar a expressão "guerra contra o extremismo violento” como preferencial. Como aponta Gottlieb (2012), “A mudança de perfil da estratégia global de contraterrorismo da América tem sido um dos esforços mais consistentes e, indiscutivelmente, bem sucedidos da administração em romper com o passado." (GOTTLIEB, 2012, p. 113)15

14 A utilização do termo "Poder Inteligente” é um dos exemplos do que Hoffmann (1977) definiu, no artigo clássico “An American Social Science: International Relations”, como a interação entre a "cozinha do poder e os salões acadêmicos” (HOFFMANN, 1977, p. 50).

15 "The rebranding of America's global counterrorism strategy has been the more consistent and arguably more successful of the administration's efforts to break from the past” (GOTTLIEB, 2012, p. 113). 
Segundo a NSS (WHITE HOUSE, 2010), a globalização impunha um leque amplo de ameaças à segurança, que não se restringiam ao terrorismo. Nesse sentido, seria improdutivo que seu gerenciamento consumisse todas as forças do país, como ocorrera em W. Bush: era preciso evitar generalizações e promover o engajamento de parceiros regionais, para evitar empreendimentos militares distantes. Ganharam destaque as questões sobre a interação dos EUA com os "novos centros de poder" (i.e as nações emergentes do Sul), a reconciliação com os aliados e a multipolaridade, além da segurança doméstica associada à reforma socioeconômica. Reiterou-se o compromisso com os direitos humanos, abolindo a tortura e as práticas de exceção de espionagem.

Até o fim do governo, Obama não conseguiu cumprir essas promessas: Guantánamo, continuou aberta, novas prisões secretas fora do território dos EUA foram denunciadas e as práticas de espionagem e demais medidas de exceção do Ato Patriota continuaram vigentes. Em 2015, o Ato Patriota foi substituído pelo Ato da Liberdade (USA Freedom Act), na sequência do escândalo das denúncias de Edward Snowden sobre as práticas ilegais da Agência Nacional de Segurança (NSA). Mantiveram-se as medidas de exceção, ainda que sob um discurso de maior transparência.

Em relação ao Oriente Médio, o turning point tático e estratégico ocorreu ainda em 2009, no discurso proferido no Cairo, Egito. Nesse discurso, fazendo uso de sua vivência pessoal e origens, Obama buscou uma reaproximação com o mundo muçulmano, comprometendo-se com a reconciliação e democratização da região. Exageros à parte, muitos apontaram esse discurso como um dos catalisadores da Primavera Árabe. Mais interessante é destacar que esse discurso foi proferido no Egito, ditadura até então apoiada pelos EUA, revelando os paradoxos tradicionais da retórica norte-americana.

Em 2011, esse discurso foi substituído por uma postura cuidadosa, à luz da Primavera Árabe que derrubava aliados norte-americanos nessas potências regionais, e dos desafios da retirada do Iraque e do Afeganistão. O período já abria as portas para as crises na Síria e na Líbia, e as situações complexas envolvendo o Irã e a questão Israel-Palestina. A esses temas, agregou-se a ascensão do EI, e a gestão de um quadro amplo de instabilidades. Em 2015, a necessidade de repensar essas dimensões e de não estender a presença na região levou à nova NSS (NSS-2015), conhecida pela "Paciência Estratégica”, ideia “interpretada" livremente como "don't do stupid stuff” (não faça coisas estúpidas). 


\section{A GWT: o Afeganistão, o Iraque, o Paquistão e o Estado Islâmico}

Iniciando sua agenda de encerramento da GWT, em 2009, no caso do Afeganistão e Paquistão, Obama realizou um encontro trilateral com os presidentes Hamid Karzai (Afeganistão) e Ali Zardai (Paquistão), reafirmando a parceria para o combate à Al Qaeda e o Talibã. O presidente anunciou um aumento de 30 mil efetivos em campo para o ano seguinte. (OBAMA, 2009) Foi aprovado, no Congresso, o projeto Kerry-Lugar-Berman, que previa o acréscimo de US\$ 1,5 bilhão/ano para a parceria com o Paquistão (HENDRICKSON, 2015). Com os aumentos progressivos, a quantidade de tropas no Afeganistão chegou a atingir o contingente de 100 mil efetivos, entre 2010 e 2011, ao passo que as perspectivas de encerramento real da guerra pareciam distantes.

Apesar das perdas de boots on the ground, o pilar da estratégia para o eixo AfPak era a utilização dos mecanismos de captura e bombardeios localizados, realizados por drones. Esses últimos já eram empregados no governo Bush e adquiriram maior impacto. Além de exercer o papel de vigilância, as aeronaves não tripuladas reduziam os custos econômicos e políticos da guerra, garantindo que menos soldados fossem enviados a campo. A contrapartida era que tais mecanismos não impediam o abatimento de civis e seu emprego culminava na violação da soberania e do espaço aéreo de outras nações. O episódio mais emblemático foi a operação realizada no Paquistão para a caça e captura de Osama Bin Laden, que foi morto em 2011.

As relações com o governo paquistanês foram abaladas, pois a operação não contou com um pedido de autorização prévio. Em resposta, a administração de Obama criticava o Paquistão16 por exercer um “jogo duplo”, auxiliando no combate ao Talibã, mas financiando outras redes terroristas como a rede Haqqani. Em alusão a essas relações, a então secretária de Estado Hillary Clinton declarou que: "Você não pode manter cobras no quintal e esperar que elas só mordam os inimigos”. (FINANCIAL TIMES, 2011)17

Em 2014, Obama assinou um acordo bilateral com o Afeganistão, prevendo a manutenção da cooperação estratégica e de um contingente de 10 mil homens no território “até o fim de 2024 e além disso” (ACKERMAN, 2014) ${ }^{18}$. Diante dessa

\footnotetext{
16 Para o mapeamento da situação geopolítica regional ver RIBEIRO e VIEIRA, 2016.

17 “You can’t keep snakes in your backyard and expect them only to bite your neighbours” (FINANCIAL TIMES, 2011). 18 "until the end of 2024 and beyond". (ACKERMAN, 2014)
} 
extensão, a guerra do Afeganistão se torna a mais longa da história norte-americana, apelidada como o "Vietnã de Obama” (GAGNON; HENDRICKSON, 2013).

No Iraque, o foco foi o cumprimento do Status of Forces Agreement. Em agosto de 2010, iniciou-se o processo de retirada das tropas de combate, finalizado em dezembro de 2011. Ainda que a retirada não tenha sido total, o Iraque só voltou ao topo das prioridades em 2014, por ocasião da tomada de territórios no país e na Síria pelo EI. Esse avanço na Síria era acompanhado pela ampliação das ações nas fronteiras próximas, incluindo Jordânia, Líbano, Arábia Saudita, o Irã e a Turquia. No Iraque, regiões estratégicas de produção de petróleo, estradas, fronteiras e represas passaram a ser controladas pelo EI entre 2013/2014. A conquista de Mosul, Tikrit e Faluja foram simbólicas desse avanço. Mas como se chega ao EI19 e ao seu projeto de construção e estabelecimento do "Califado Islâmico"?

Segundo Layne (2015), os desequilíbrios políticos e econômicos causados pela presença das tropas ocidentais facilitaram seu nascimento em meados de 2007, como ramificação da Al Qaeda. Somente após os levantes da Primavera Árabe e o início do conflito na Síria (2011), o grupo encontrou espaço para crescer e angariar novos territórios e seguidores. O EI utilizava táticas de extrema violência e com impacto midiático, como massacres de populações civis, decapitações e tortura, para assegurar sua expansão.

No Ocidente, isso se refletiu em ondas de atentados de pequeno e médio porte, alguns assumidos pelo EI, outros por seguidores de causas similares. Os atentados aconteceram tanto nos EUA (Boston) como em cidades como Paris e Nice, na França, Bruxelas, na Bélgica (cidade sede da OTAN), e Hannover, na Alemanha, entre 2013 e 2016.

Obama retomou os bombardeios ao Iraque, em 2014, sem consultar as Nações Unidas. Essas intervenções aéreas foram acompanhadas pela França, e alguns países como Alemanha e Reino Unido forneceram apoio logístico (participaram dos esforços países como Egito, Kuwait, Omã, Arábia Saudita, Qatar, Bahrein, Jordânia e Líbano). O auxílio às populações civis incluiu o fornecimento de alimentos, medicamentos e armamentos. Naquele ano, o presidente declarou guerra ao Estado Islâmico (OBAMA, 2014) e iniciou a elaboração do pedido de uma nova autorização para o uso da força militar (AUMF) ao Congresso, em 2015. Essa última estabelecia uma atuação limitada e defensiva, mas o debate sobre sua aprovação ficou travado no Legislativo. Enquanto isso, os avanços do exército

19 HARLING, 2017. 
de Bagdá em relação ao EI têm sido alcançados menos por influência e suporte norte-americanos e mais pela atuação das forças curdas Peshmerga e por milícias xiitas ligadas ao Irã (LAYNE, 2015).

A ineficiência e demora das ações ocidentais diante do EI, e as crises e desdobramentos do pós conflito iraquiano e afegão, associados à Primavera Árabe (ver item b), produziram um caos político regional. Somada aos fenômenos aqui relatados, não se pode deixar de mencionar a intensificação das ondas migratórias dessa região para a União Europeia, que passou a ser conhecida como "crise dos refugiados”. Tais ondas migratórias marítimas e terrestres geram inúmeras pressões à economia, sociedade e política europeias ${ }^{20}$, favorecendo o crescimento da extrema direita, que se opõe à recepção dos refugiados, criando profunda instabilidade na Turquia. A crise humanitária prosseguiu com Obama, e não parece ter sinais de reversão. Nos EUA, ela amplia, ao lado de outros fatores, a influência da direita, vide a plataforma do presidente republicano eleito Donald Trump.

Compartilhando das conclusões de Christopher Layne (2015), o que se argumenta é que os resultados de Obama na temática do combate ao terrorismo foram ambivalentes. Isso porque a redução dos contingentes militares em campo e o exercício da cooperação com aliados regionais não foram suficientes para encerrar os conflitos, posto que o presidente deu continuidade à atuação das tropas. Não há, como diz McCrisken (2011), um descolamento total em relação às condutas do governo Bush.

\section{A Primavera Árabe: Crise e Desdobramentos}

De todos os desdobramentos das relações com o Oriente Médio, a Primavera Árabe foi o mais inesperado para os cálculos estratégicos da administração Obama. Iniciados na Tunísia, em 2011, os levantes populares se alastraram por outros países, como Egito, Líbia e Síria. Na maioria dos casos, os processos de transição política sofreram retrocessos, por conta do retorno do autoritarismo e deflagração de guerras civis. O movimento era direcionado contra governos com os quais os EUA mantinham relações de longa data, o que dificultou, inicialmente, uma resposta mais proativa.

No caso egípcio, os protestos na Praça Tahrir fizeram com que, em fevereiro de 2011, o presidente declarasse apoio à transição política, a despeito das relações

20 O BREXIT, saída do Reino Unido da União Europeia, é um dos subprodutos dessas crises, uma vez que evidencia o componente nacionalista e xenófobo. 
de décadas conservadas com o governo de Hosni Mubarak. Após a queda desse último, os EUA desempenharam um papel mais ativo, oferecendo suporte ao processo eleitoral ocorrido no país em 2012, o qual deu o poder à Mohammed Morsi, um representante da Irmandade Muçulmana. Os eventos posteriores tomaram rumos inesperados: com menos de um ano de governo, Morsi sofreu um golpe da junta militar liderada por Abdel Fattah al-Sisi (atual governante do Egito). O presidente eleito em 2012 se encontra, até o presente, encarcerado e condenado à prisão perpétua por, de acordo com as declarações oficiais, ter contribuído com fugas de prisões e ataques a policiais no período das manifestações contra Mubarak.

Assim como no Egito, a Líbia passou por uma desestabilização política, agravada pela intervenção direta das potências ocidentais, em 2011. A violenta resposta do governo de Muammar Gaddafi às reverberações da Primavera Árabe no país levou à passagem da Resolução 1973 da ONU. Com 10 votos favoráveis e 6 abstenções (dentre elas, uma brasileira), a resolução autorizava o estabelecimento de no-fly zones na Líbia e permitia aos Estados membros: " to take all necessary measures... to protect civilians and civilian populated areas under threat of attack in [Libya], including Benghazi, while excluding a foreign occupation force of any form" (WEISSMAN, 2016, p. 673). Baseada no discurso humanitário da "Responsabilidade de Proteger", a operação Odissey Dawn consistiu em uma série de esforços militares nacionais, que levaram à captura e morte de Gaddafi e, posteriormente, foram transferidos à OTAN na renomeada operação Unified Protector. Diante do protagonismo europeu em ambas as investidas, um funcionário do serviço americano afirmou que a estratégia do país consistia em "liderar por trás”, angariando a Obama uma série de críticas, principalmente dos grupos conservadores.

Contrariando essa visão, Weissman (2016) afirma que os EUA desempenharam um papel relevante, oferecendo as tecnologias de ataques aéreos e vigilância, em posse da OTAN. Obama foi um importante apoiador da Resolução 1973. Após a queda de Gaddafi e o início das atividades ocidentais, a Líbia sucumbiu em desagregações políticas e conflitos entre milícias. Além do enfraquecimento do país, a violência ampliou os fluxos de refugiados na região, desencadeando a força de grupos extremistas no Mali e no Norte da África. (WEISSMAN, 2016)

Um dos símbolos do fracasso relativo da intervenção na Líbia foi a morte do Embaixador dos EUA no país em 2012, Christopher Stevens, em um ataque ao consulado em Benghazi (que vitimou mais cidadãos norte-americanos). A ausência 
de segurança ao corpo diplomático e a incapacidade das forças ocidentais de promover uma transição política na Líbia indicavam as limitações de ação dos EUA. Esse episódio, ocorrido com Hillary Clinton à frente do Departamento de Estado, foi utilizado por seus adversários na campanha presidencial de 2016, em particular por seu oponente republicano Donald Trump.

Em acréscimo ao desastroso histórico da "Primavera Árabe", a guerra civil na Síria, que completa, em 2017, seis anos, se tornou o "assunto não resolvido" da presidência. Apesar de declarar inúmeras vezes a necessidade de que o regime de Bashar al-Assad fosse retirado do poder e de apoiar financeiramente a atuação de grupos rebeldes e moderados anti-Assad, o presidente encerrou o segundo mandato dividindo opiniões acerca de sua decisão de não iniciar uma nova intervenção militar por terra. Pela perspectiva política, tal opção mantém coerência em relação às vozes da administração e da opinião pública doméstica, que rejeitavam a aplicação das forças militares em novo território. Do ponto de vista geopolítico, é encarada como fraqueza pela oposição conservadora, uma vez que o vácuo criado permitiu a atuação de outras potências, como Irã, Turquia²1 e Rússia22.

Critica-se a inação de Obama no caso sírio $^{23}$, e suas opções estratégicas pelo custo humanitário e implicações geopolíticas. Na visão de alguns grupos, as ações assemelham-se muito ao caso líbio, no qual se permitiu o avanço do EI ao enfraquecer o governo da situação (Assad), mesmo com seu autoritarismo. A ausência de uma avaliação clara sobre as forças em choque na Síria mantém o impasse no conflito, cujas negociações de paz se arrastam desde 2011, sem resultados concretos. Em 2016, as conversações foram suspensas após mais uma rodada de negociações em Genebra ${ }^{24}$, nas quais, além das potências ocidentais, a Rússia e as Nações Unidas, também foram incluídos o Irã e o governo Assad (em desagrado à oposição doméstica), antes considerado “inviável”. A Primavera Árabe e seus desdobramentos mantêm um quadro de instabilidade amplo. Contudo, foi essa mesma instabilidade que afetou as considerações estratégicas para o Irã.

21 A Turquia, pivô geopolítico entre o Ocidente e o Oriente, é um dos países mais atingido pelas crises regionais, como as guerras, ondas migratórias e disputas geopolíticas.

22 A Rússia recuperou protagonismo na Síria em 2015 quando iniciou intervenções aéreas contra o EI (para fortalecer a gestão Assad). Exerce papel relevante nas negociações de paz na Síria e em barrar uma intervenção militar terrestre do ocidente. O período é de pressão devido à crise da Ucrânia, em andamento desde 2014, e a situação síria reforçou simbolicamente o poder de iniciativa do Kremlin.

23 Para Smith (2016), Obama admitiu sentir-se responsável, em alguma medida, pelos massacres na Síria.

24 Para uma síntese recomenda-se Rocha, Julio e Graeff, 2016. 


\section{O Irã: Contenção e Negociação}

Para Obama, a pacificação do cenário pós GWT se encontrava ligado ao maior engajamento iraniano nas estratégias ocidentais, garantindo a cooperação e a contenção das aspirações nucleares de Teerã. À revelia da oposição republicana, o presidente sinalizou intenções de restabelecer os diálogos com o Irã, mesmo com Mahmoud Ahmadinejad no poder (SINGH, 2012). Em 2009, o diálogo EUAIrã foi pautado pelo foco de Washington nos direitos humanos, mas também pelo início das conversações entre os membros do P5 +1 (membros do Conselho de Segurança e Alemanha) e Irã, a respeito do programa nuclear.

Após a rejeição de uma proposta para o enriquecimento (a baixos níveis) do urânio iraniano na Rússia e na França, as sanções ao país foram retomadas, tanto multilateralmente quanto bilateralmente, pelos EUA e por países da União Europeia (UE). As medidas envolviam a limitação de transações econômicas com o Irã, bem como de transferência de armamentos e tecnologia ao país, o que, no interregno de 2010 a 2011, começou a afetar o bem-estar social da população. Em 2010, destaca-se o papel desempenhado pela diplomacia brasileira que, com auxílio turco, promoveu a negociação de um acordo tripartite com o Irã, aos moldes da proposta de 2009. O acordo foi rechaçado pelo Conselho de Segurança das Nações Unidas e novas sanções foram implementadas, via Resolução 1929 (SINGH, 2012).

De acordo com Amorim (2015), a participação brasileira e turca na negociação do Acordo de 2010 havia sido solicitada pelo governo democrata que percebia o processo das negociações multilaterais como travadas. Obama acreditava que, como parte da política de descongelamento, a negociação com o Irã era prioritária, mas que os interlocutores conhecidos, EUA, União Europeia e Nações Unidas, não poderiam conduzi-la com credibilidade. Nos EUA eram fortes os sinais de oposição a qualquer negociação com o Irã de ambos os partidos, democrata e republicano, devido às pressões do lobby israelense.

O Acordo Tripartite foi negociado pelas chancelarias turca e brasileira com o governo Ahmadinejad, mas, ao ser anunciado, foi rechaçado nos EUA, levando a administração Obama a retirar seu apoio. No Brasil, ano de eleições presidenciais, o acordo foi criticado pela oposição conservadora. Após essa oportunidade perdida, como destaca Amorim (2015), a questão iraniana retomou seu padrão de pressões ocidentais e recuo iraniano.

Porém, a Primavera Árabe, em 2011, reabriu o espaço regional para a ampliação da influência geopolítica iraniana, principalmente em Iraque e Síria (LAYNE, 
2015). A ascensão do EI nesses cenários contribuiu para reforçar tal importância estratégica do país que, apesar da crise econômica, sustentava sua condição política soberana e um regime estável. Os prospectos de cooperação se ampliaram em 2013, com a eleição do moderado Hassan Rouhani, com quem Obama travou a primeira conversa por telefone, após o rompimento das relações entre os países, em 1979.

Os diálogos entre o Irã e P5 + 1 floresceram. Apesar de sofrerem uma série de extensões em seus prazos, por conta de desacordos entre Teerã e o Ocidente acerca da retirada das sanções impostas ao país, em julho de 2015 o acordo final foi assinado, prescrevendo a limitação do número de centrífugas e da quantidade de urânio enriquecido no Irã e a retirada total das sanções econômicas.

Nos EUA, visando garantir a implementação do acordo e revogação das sanções, Obama assinou uma Ordem Executiva, em janeiro de 2016 (NATIONAL ARCHIVES, 2016), o que angariaria críticas domésticas (principalmente na bancada republicana do Congresso, majoritária desde 2014) e de aliados internacionais, que temiam as consequências geopolíticas da concretização do acordo. Entre esses últimos, a oposição mais veemente veio de Israel. O premiê Netanyahu chegou a discursar no Senado dos EUA contra o Acordo, simbólico do poder dos grupos de interesse israelenses no país.

\section{O Processo de Paz Israel e Palestina}

Embora existam muitos ruídos a respeito de um suposto afastamento entre EUA e Israel ao longo do governo Obama, a trajetória da relação especial não sofreu significativas alterações. Um exame pragmático do cenário geopolítico Israel-Palestina indica que o núcleo básico da questão continuou o mesmo: a estagnação do processo de paz, a permanência das políticas de Israel para os assentamentos em territórios ocupados, a progressiva contenção das ações de autonomia palestina e a destruição sistemática do que restou da ANP.

Houve, porém, discordâncias em tom e prática das gestões Obama e Netanyahu, devido às prioridades norte-americanas no entorno de Israel, que afetam os interesses dessa nação. Foram tais prioridades que levaram a essas acusações de afastamento, e que sinalizaram mais uma ambiguidade da gestão Obama, e da ausência de compromisso com uma solução negociada para a paz. Mas, afinal, em que consiste esse suposto conflito Obama e Israel?

Para Saltzman (2017), o estremecimento da "relação especial” EUA-Israel não se inicia a partir do acordo nuclear iraniano, apresentando sinais desde 2009, por 
conta das críticas de Obama à construção dos assentamentos israelenses. Após o icônico discurso democrata no Cairo, Netanyahu se demonstrou disposto a aceitar a solução de "dois Estados", mas impôs uma série de condicionantes, tais quais o reconhecimento de Jerusalém como capital de Israel e a desmilitarização da Palestina, o que contrariou a administração de Obama e esfriou ainda mais a relação bilateral (SALTZMAN, 2017).

Episódios como a Primavera Árabe e as negociações com o Irã apenas contribuíram para a intensificação dos desencontros. Netanyahu criticou o fato de Obama apoiar a derrubada de Hosni Mubarak, no Egito, um aliado norte-americano de longa data. A assinatura do acordo nuclear, por sua vez, foi a "gota d'água" para Netanyahu, que fez um inflamado discurso opositivo em uma sessão conjunta do Congresso americano, em 2015 (SALTZMAN, 2017).

A despeito de tais conflitos, Obama manteve seus compromissos com a segurança de Israel e com o lobby judaico, transferindo ao país mais armas e recursos que seus antecessores (SHLAIM, 2016). Em nenhum momento, o presidente apoiou iniciativas para a retomada do processo de paz. Chama atenção o fato de que a proposta do Mapa de Estrada, ainda na gestão W. Bush, foi a última tentativa concreta dos EUA de aparecerem como mediadores de novas negociações diplomáticas. Obama não apoiou o pedido de inclusão da Palestina como membro pleno da ONU, iniciado por Abbas em 2011, tendo em vista que essa ação traria como pressuposto o reconhecimento formal da Palestina como Estado.

Por outro lado, em dezembro de 2016, os EUA garantiram, com uma abstenção, a passagem de uma resolução no CSONU que condenava a política de assentamentos e determinava o estabelecimento de um Estado independente palestino com capital em Jerusalém. Obama autorizou unilateralmente o envio de uma ajuda de US\$ 221 milhões à ANP (BUSINESS INSIDER, 2017), contrariando o Congresso. Apesar dessa postura aparentemente pró Palestina, a ausência de um esforço diplomático concentrado, com metas claras, indica a estagnação de um processo de paz concreto e a falta de perspectivas de uma solução mediada.

\section{Conclusões}

Em World Order, Kissinger (2014) afirma que a compreensão do legado de qualquer líder depende de uma avaliação de médio e longo prazo dos impactos de suas decisões. Visão similar é trazida por Bentley e Holland (2017), ao afirmar 
que os resultados da Doutrina Obama serão "consequenciais". Entretanto, isso não exime o analista de apresentar um panorama tanto temático quanto crítico da gestão que findou em janeiro de 2017, dando lugar à administração de Donald Trump e sua retórica do Make America Great Again. Assim como Obama explorou as fragilidades da era W. Bush, o mesmo se repetiu com Trump.

Para Quinn (2017), "mesmo com o risco de apontar uma realidade banal, todas as administrações representam uma combinação de continuidade e mudança. Ninguém começa o mundo de novo.”25

No campo da continuidade, Obama não promoveu um pleno desengajamento do Oriente Médio, uma vez que o encerramento oficial das guerras do Iraque e do Afeganistão foi precedido por acordos bilaterais com ambos para a manutenção de efetivos norte-americanos em solo. Isso não impediu a expansão do EI, que cresceu na fragmentação gerada pelas operações estadunidenses e pelas disputas internas em países como Iraque, Síria, Líbia, dentre outros. No que se refere à descontinuidade, inserem-se a mudança da retórica da GWT, o incremento do uso de táticas multilaterais, drones e a mudança diante do Irã. Segundo Kitchen (2017),

(...) o contraterrorismo se expandiu por meio da Guerra do Iraque, passando a incluir uma tentativa de reorganizer o Oriente Médio na totalidade. Esse novo imperativo abrangente da política dos Estados Unidos foi buscado majoritariamente com ferramentas militares (...) No Oriente Médio, a geografia original da Guerra Contra o Terror, da qual Obama tentou afastar os Estados Unidos, foi renovada depois da Primavera Árabe em um novo e transformado mapa regional. (KITCHEN, 2017) ${ }^{26}$

Em nenhum momento, Obama deu sinais de que o Oriente Médio deixaria de ser prioritário, confirmando avaliações como a de Bandeira (2016), de que o país não abrirá mão dessa região como pivô geopolítico. Para isso, como observam Jackson e Sui (2017), estratégias e táticas mesclaram tanto evolução quanto adaptação. Uma mescla que não gerou estabilidade ou impediu o spill-over da violência no Oriente Médio e seus subprodutos, como a crise dos refugiados, a crescente xenofobia e a expansão do nacionalismo.

25 "At risk of signalling a banal truth, all administrations represent a combination of continuity and change. No one gets to begin the world again”. (Quinn, 2017)

26 (...) counterterrorism was expanded through the Iraq War to encompass an attempt to comprehensively reorder the Middle East. This new overaching imperative of US foreign policy was pursued with overwhelming military tools (...) In the Middle East, the original geography of the War on Terror that Obama had sought to reroute the United States away was renewed post-Arab Spring in a new and shifting map of the region. (KITCHEN, 2017) 


\section{Referências}

ACKERMAN, Spencer. New Afghanistan pact means America's longest war will last until at least 2024. The Guardian. 30 set. 2014. Disponível em: < https://www. theguardian.com/world/2014/sep/30/us-troops-afghanistan-2024-obama-bilateralsecurity-agreement > . Acesso em: 20 jan. 2017.

AMORIM, Celso. Teerã, Ramalá e Doha- memórias da política externa ativa e altiva. Rio de Janeiro: Benvirá. 2015.

BANDEIRA, Luiz Alberto Moniz. A desordem mundial- o espectro da total dominação. Civilização Brasileira: Rio de Janeiro. 2016.

BENTLEY, Michelle and HOLLAND, Jack. "Introduction" in BENTLEY, Michelle and HOLLAND, Jack (ed). The Obama doctrine - a legacy of continuity in US foreign policy?. London and New York: Routdlege. 2017.

BRZEZINSKI, Zbigniew. Strategic vision. New York: Basic Books. 2012.

BUSINESS INSIDER. Why Obama sent the Palestinians \$221 million during his last hours in office". 24 jan. 2017. Disponível em: < http://www.businessinsider.com/obamaqueitly-sends-221-million-to-palestine-2017-1 > . Acesso em: 29 jan. 2017.

COOPER, Danny. Neoconservantism and American foreign policy. London and New York: Routledge. 2011.

DAALDER, Ivo H.; LINDSAY, James M. America unbound. Washington: Brookings Institution. 2003.n

DOMBROWSKI, Peter. Renewing US National Security Policy- something old, something new. In: HOOK, Steven; SCOTT, James M. (ed). American renewal? Washington: CQ Press. 2012.

FINANCIAL TIMES. Clinton warns Pakistan on militant 'snakes'. 21 out. 2011. Disponível em: < https://www.ft.com/content/93147c90-fbc7-11e0-9283-00144feab49a > . Acesso em: 20 jan. 2017.

FRAGILE STATES INDEX. 2016. Disponível em http://fsi.fundforpeace.org/. Acesso em: 20 fev. 2017.

GOTTLIEB, Stuart. Change and continuity in America's counterterrorism strategy under Obama. In: HOOK, Steven; SCOTT, James M. (ed) American renewal? Washington: CQ Press. 2012.

GAGNON \& HENDRICKSON, Frédérick, Ryan C. The United States versus Terrorism: From the Embassy Bombings in Tanzania and Kenya to the Surge of forces in Afghanistan. In: CARTER, Ralph G. (org). Contemporary Cases in US foreign policy. 5 ed, California: SAGE, 2013, p. 11- 40. 
HAASS, Richard. War of necessity-War of choice- a memoir of two Iraq wars. New York: Simon and Schuster 2009.

HALLIDAY, Fred. The Middle East in International Relations- power, politics and ideology. Cambridge University Press: Cambridge. 2005.

HARLING, Peter. “Estado Islâmico, um monstro providencial”. Disponível em: http://diplomatique.org.br/estado-islamico-um-monstro-providencial/. Acesso em: 15 jan. 2017.

HENDRICKSON, Ryan C. Obama at war. Congress and the imperial presidence. Kentucky: The University Press of Kentucky, 2015.

HOFFMANN, Stanley. An American Social Science: International Relations. Daedalus, Vol. 106, No. 3, Discoveries and Interpretations: Studies in Contemporary Scholarship, Volume I, Summer, 1977, p. 41-60.

JACKSON, Richard;TSUI, Chin-Kuei. War on terror II- Obama and the evolution of US counterterrorism. In: BENTLEY, Michelle;HOLLAND, Jack (ed). The Obama Doctrinea legacy of continuity in US foreign policy?. Routledge: New York. 2017.

KENNEDY, Paul. Ascensão e queda das grandes potências. Rio de Janeiro: Campus. 1989. KISSINGER, Henry. World Order. Penguin Press: New York. 2014.

KITCHEN, Nicholas. Ending permanent war- security and economy under Obama. In: BENTLEY, Michelle; HOLLAND, Jack (ed). The Obama Doctrine- a legacy of continuity in US foreign policy?. Routledge: New York. 2017.

LAYNE, Christopher. Obama's missed opportunity to pivot away from the Middle East. Insight Turkey. Vol. 17, N 3, 2015.

MCCRISKEN, Trevor. Ten years on: Obama's war on terrorism in rhetoric and practice. International Affairs, vol. 87, $\mathrm{n}^{\circ} .4,2011, \mathrm{p} .781-801$.

NATIONAL ARCHIVES. “Executive Order 13716 of January 16, 2016”. Disponível em: < https://www.gpo.gov/fdsys/pkg/FR-2016-01-21/pdf/2016-01325.pdf > .Acesso em: 20 jan. 2017.

NYE JR, Joseph S. The future of power. New York: Public Affairs, 2011.

OBAMA, Barack. “The New Way Forward - The President's Address”. White House, 1 dez. 2009. Disponível em: < https://obamawhitehouse.archives.gov/blog/2009/12/01/ new-way-forward-presidents-address > .Acesso em: 20 jan. 2017.

OBAMA, Barack. President Obama: "We Will Degrade and Ultimately Destroy ISIL”. 10 set. 2014. Disponível em: < https://www.whitehouse.gov/blog/2014/09/10/presidentobama-we-will-degrade-and-ultimately-destroy-isil > .Acesso em: 3 set. 2015.

PECEQUILO, Cristina Soreanu. Os EUA e o século XXI. Rio de Janeiro: Elsevier, 2013.

QUINN, Adam. Restraint and constraint- a cautious president in a time of limits. In: BENTLEY, Michelle; HOLLAND, Jack (ed). The Obama Doctrine- a legacy of continuity in US foreign policy?. Routledge: New York. 2017. 
RIBEIRO, Erik Herejk e VIEIRA, Maria Gabriela. “Índia e Paquistão na Organização para a Cooperação de Xangai: a busca por estabilidade política e integração na Ásia”. Boletim de Conjuntura Nerint, 1 (3), Novembro 2016. p. 7-14. Disponível em https://www.ufrgs.br/ nerint/wp-content/uploads/2016/12/POR-Ribeiro-Vieira.pdf. Acesso em: 20 fev. 2017. ROCHA, Douglas de Quadros; JULIO, Isabela Souza; GRAEFF, Patrícia. As conversações de paz sobre o principais avanços e diferenças entre as reuniões de Viena (2015) e Genebra III (2016). Boletim de Conjuntura Nerint, vol. 1, $\mathrm{n}^{\circ}$. 1, Julho. 2016, p. 5-13. Disponível em https://www.ufrgs.br/nerint/wp-content/uploads/2016/07/Boletimv1n1-transicaopoliticamianmar.pdf. Acesso em: 20 fevereiro 2017.

SALTZMAN, Ilai Z. Not So "Special Relationship”? US-Israel Relations During Barack Obama’s Presidency. Israel studies, vol. 22, n. 1, 2017.

SELIKTAR, Ofira. Navigating Iran-From Carter to Obama. New York: Palgrave Macmillan. 2012 .

SHLAIM, Avi. Barack Obama, John Kerry, and the Palestine saga. Al Jazeera. 24 dez. 2016. Disponível em: < http://www.aljazeera.com/indepth/opinion/2016/12/barack-obamajohn-kerry-palestine-saga-161224101744800.html > .Acesso em: 20 jan. 2017.

SINGH, Robert. Neoconservantism- theory and practice. In: PARMAR, Inderjeet; MILLER, Linda B.; LEDWIDGE, Mark (ed). New directions in US Foreign Policy. London and New York: Routledge. 2009.

SINGH, Robert. Barack Obama's Post-American foreign policy: the limits of engagement. New York: Bloomsbury, 2012.

SMITH, David. Obama reflects on Syria at farewell press conference: 'I always feel responsible'. The Guardian. 2016. Disponível em: < https://www.theguardian.com/ us-news/2016/dec/16/obama-syria-assad-aleppo-final-press-conference > . Acesso em: 20 jan. 2017.

TEIXEIRA, Carlos Gustavo Poggio. Quatro temas fundamentais do pensamento neoconservador em política externa. Rev. bras. polít. int., Brasília, v. 50, n. 2, Dec. 2007, p. 80-96. Disponível em: < http://www.scielo.br/scielo.php?script = sci_arttext\&pid $=$ S0034-73292007000200006\&lng $=$ en\&nrm $=$ iso $>$. Access on 14 Apr. 2017.

TRAUB, James. The Hillary Clinton doctrine. 2015. Disponível em: http://foreignpolicy. com/2015/11/06/hillary-clinton-doctrine-obama-interventionist-tough-mindedpresident/. Acesso em: 10 jun. 2016.

THE WHITE HOUSE. "National Security Strategy”. Washington, 2010. Disponível em: < http://www.whitehouse.gov/sites/default/files/rss_viewer/national_security_ strategy.pdf > .Acesso em: 10 jun.2013.

THE WHITE HOUSE. “National Security Strategy”. Washington, 2015. Disponível em: < http://www.whitehouse.gov/sites/default/files/docs/2015_national_security_ strategy.pdf\&gt; Acesso em: 12 fev. 2015. 
VISENTINI, Paulo Fagundes. O grande Oriente Médio. Rio de Janeiro: Ed. Elsevier, 2014. WALTZ, Kenneth. Why Iran should get the bomb. Foreign Affairs, vol. 91, nº. 4, July/ August 2012. p. 2-5.

WEISSMAN, Stephen R. Presidential Deception in Foreign Policy Making: Military Intervention in Libya 2011. Presidential Studies Quarterly, Vol. 46, No. 3, September 2016, 669-690. 


\title{
O sentimento anti-Japão na China: origens, estímulos e consequências ${ }^{1}$
}

\author{
The anti-Japan sentiment in China: \\ origins, stimulus and consequences
}

DOI: $10.21530 /$ ci.v12n2.2017.633

Hércules Paulino de Souza²

\section{Resumo}

No atual panorama global das relações entre potências, podemos caracterizar a relação entre China e Japão como uma das mais tensas e com grande potencial de conflito. Tal condição deriva dos fatos ocorridos no curso do último século, majoritariamente ligados às invasões japonesas durante as duas guerras sino-japonesas. As agressões japonesas acabaram por fazer do Japão um protagonista na inflição do “século de humilhação” ao povo chinês (1839-1949), ao lado das potências ocidentais, que também submeteram a nação chinesa a conflitos e "tratados desiguais". Às vívidas experiências da violência promovidas pelos japoneses seriam somadas políticas de propaganda, como filmes e canções, demonstrando a expulsão dos "demônios japoneses" pelas forças comunistas, formando sobre tal memória histórica o capital político de libertador nacional do Partido Comunista. Tal sentimento antijaponês perdurou no decorrer das décadas, encontrando terreno fértil para se propagar com o advento das tecnologias de informação vinculadas à internet, ao enfraquecimento da ideologia comunista e à ascensão do nacionalismo. Portanto, pretendemos apresentar como tal sentimento anti-Japão foi fomentado no passado e na atualidade, como convulsionou a população chinesa em determinados momentos da história recente, ao sair do controle do Estado, e suas consequências para a relação sino-japonesa em um momento em que os dois países passam por um período de afirmação no cenário global.

Palavras-chave: China; Japão; sentimento antijaponês; nacionalismo

1 O presente artigo é parte de pesquisa financiada pela CAPES - Coordenação de Aperfeiçoamento de Pessoal de Nível Superior.

2 Programa de Pós-Graduação em Ciências Sociais da Faculdade de Filosofia e Ciências de Marília, Universidade Estadual Paulista - Unesp, Marília/SP, Brasil. E-mail: herculespaulino@gmail.com

Artigo submetido em 12/02/2017 e aprovado em 11/04/2017. 


\begin{abstract}
In the current global picture of relations between powers, we can characterize the relation between China and Japan as one of the most tense and with a great potential for conflict. Such condition derives from the events that took place in the last century, mostly linked to the Japanese invasions during the two Sino-Japanese wars. The Japanese aggressions eventually made Japan a protagonist in the infliction of the Century of Humiliation to the Chinese people (1839-1949), alongside the Western Powers, who also subjected the Chinese nation to conflicts and 'unequal treaties'. To the vivid experiences of the violence promoted by the Japanese would be added propaganda policies, such as movies and songs, demonstrating the 'Japanese demons' expulsion by the communist forces, forming on such historical memory the Communist Party political capital as national liberator. Such antiJapanese sentiment persisted over the decades and found fertile ground to spread with the advent of internet-related information technologies, the weakening of communist ideology and the rise of nationalism. Therefore, we intend to present how such anti-Japan sentiment was fomented in the past and present, how it convulsed the Chinese population at certain moments in recent history when it came out of state control, and its consequences for the Sino-Japanese relation at a time the two countries are going through a period of affirmation on the global stage.
\end{abstract}

Keywords: China; Japan; anti-Japanese sentiment; nationalism

\title{
Introdução
}

A relação sino-japonesa é uma das mais complexas a se analisar no ambiente diplomático atual, assim como é uma das mais importantes em termos econômicos. China e Japão são respectivamente segunda e terceira maiores economias globais, grandes parceiros econômicos, vizinhos muito próximos geograficamente e com uma história recente de conflitos. Recentemente, tal relação se caracteriza por um forte vínculo econômico - tendo a China se tornado maior parceiro comercial do Japão a partir de 2008, e o Japão se consolidado como segundo grande parceiro econômico da China na primeira década do século XXI (SIMOES; HIDALGO, 2011) - porém, tal laço econômico refletiu pouco sobre a evolução positiva da relação diplomática entre as duas nações. Apontar e refletir brevemente sobre essa relação diplomática “fria” entre os dois países é nosso objetivo no presente trabalho.

A relação sino-japonesa é um exemplo importante de como a história pode influenciar consideravelmente e refletir-se de maneira intensa na relação atual e futura entre nações. Para entendermos os motivos dessa frieza política 
que caracteriza a relação, é necessário que olhemos não apenas para os fatos históricos passados que envolveram os dois povos, mas também como parte dos sentimentos gerados por tais acontecimentos foram ora reprimidos, ora fomentados. Desentendimentos bilaterais recentes desencadearam eventos onde ficou evidente a opinião negativa entre os dois povos, e tais divergências não poderão ser entendidas sem buscar origem e motivos para que tais sentimentos perdurem até a atualidade - o que buscamos fazer aqui de forma sucinta.

Como a temática histórica é extensa, abrangendo fatos e memória dos povos chinês e japonês, assim como ações políticas recentes por parte de líderes de ambos os países, optamos por trabalhar aqui apenas com o que se refere à parte chinesa da relação. Na primeira parte do trabalho, optamos por demonstrar os fatos históricos que possibilitaram que o sentimento anti-Japão na China ganhasse força no decorrer das últimas décadas - a evocação desses fatos seria primordial para o discurso de futuros líderes e campanhas patrióticas. Na interpretação que seguimos, as divergências entre China e Japão se evidenciaram já nas formas distintas de reação e adaptação à conjuntura imperialista ocidental que se impunha na Ásia durante o século XIX, tendo os distintos modelos de adaptação levado aos conflitos iniciais entre os dois países. Na segunda parte, demonstramos como ocorreu a reaproximação e normalização da relação sino-japonesa e os impactos pela forma através da qual foi efetuada. Exploramos, ainda, como o sentimento anti-Japão se torna progressivamente um elemento do nacionalismo patriótico chinês, em um ambiente doméstico onde a liderança comunista chinesa necessita de outros elementos - para além da ideologia marxista-leninista - que justifiquem sua legitimidade como governante da China. Por fim, concluímos com uma breve exposição sobre algumas das consequências ocasionadas pelo aumento do sentimento antijaponês entre a população chinesa nas últimas décadas.

O conceito de nacionalismo é utilizado aqui de forma recorrente, e visto sua complexidade em termos de definição e distintas abordagens no campo dos fenômenos sociais, adotamos a elucidação sucinta de Ekman e Pajon como aplicável aos nossos objetivos. Para as autoras, o nacionalismo é um estado de espírito que nutre o sentimento de pertença a um grupo, por meio da mobilização de um conjunto de fatores comuns, incluindo território, valores, idioma, história, identidade e um projeto nacional, sendo também um instrumento político utilizado pelas elites do Estado para mobilizar as massas, assim como por grupos nacionalistas para influenciar as escolhas políticas do governo (EKMAN; PAJON, 2015). 
Aqui também é fundamental frisar que o sentimento anti-Japão na China não é apenas resultado de campanhas patrióticas ou do nacionalismo chinês. Parte importante desse sentimento surge como reação a ações nacionalistas de líderes políticos japoneses, ações consideradas como ofensas às vítimas da invasão japonesa. Aqui citaremos brevemente essas ações da classe política japonesa, buscando esclarecê-las da melhor maneira possível, de forma consoante com a delimitação do tema aqui proposto, propondo-nos a fazer uma discussão do nacionalismo japonês em trabalhos posteriores. Portanto, durante a leitura do trabalho, é necessário ter em mente que grande parte das ações nacionalistas da população chinesa é reação ao nacionalismo fomentado no Japão.

\section{As origens históricas do sentimento anti-Japão na China}

A rivalidade recente entre China e Japão, assim como a origem das desconfianças chinesas em relação à política exterior de Tóquio, encontra suas raízes no desdobramento de eventos de escala global da passagem do século XIX para o século XX.

Em tal período, o imperialismo europeu, que se desenvolvia desde o século XVI, necessitava de maior expansão para sua manutenção. Tendo na expansão geográfica e na exploração das demais regiões do mundo os pilares do acúmulo de poder econômico e militar, as potências europeias - através da articulação do equilíbrio de poder - tiveram a capacidade de formar extensos impérios ultramarinos. Utilizando as riquezas provenientes das Américas, as potências europeias puderam se fortalecer internamente e posteriormente partiriam para a exploração da produção, dos mercados e do comércio asiático (ARRIGHI, 2008). Portanto, uma nova onda expansionista das potências ocidentais, rumo a Ásia e África, se daria com maior intensidade após os movimentos de independência nas Américas, durante o século XIX, e seus impactos econômicos aos Estados e companhias de comércio europeias. Em tal contexto, as sociedades asiáticas seriam abertas por consentimento ou força, como ficou evidente pelas estratégias agressivas e tratados desiguais impostos à China pelas potências ocidentais. O antigo Império Chinês foi submetido a uma série de agressões que seria conhecida como o "século da humilhação chinesa", iniciado em meados do século XIX, tendo a Primeira Guerra do Ópio como marco, em 1839, terminando apenas em 1949 com a fundação da República Popular da China. Durante tal período, as 
potências ocidentais submeteram o Império Chinês a diversos tipos de intervenções que ofendiam sua civilização e feriam sua soberania e integridade ${ }^{3}$ - como o bombardeio de portos, os impactos sociais do contrabando e uso disseminado de ópio, concessões territoriais e privilégios comerciais. Aos dirigentes políticos do Japão, observando as agressões à China e sob ameaça das potências imperialistas ocidentais, não restaria alternativa se não ceder às demandas de abertura comercial e à assinatura de tratados desiguais em 1858 (SARAIVA, 2008).

A dinâmica imperialista ocidental acabaria por redefinir a política mundial segundo o modelo de desenvolvimento europeu, projetando para as demais regiões do globo seus conceitos de soberania territorial e Estado, uma projeção do que seria a Europa. Como destacam Acharya e Buzan (2010), o imperialismo europeu causou grande impacto intelectual nas colônias, gravando entendimentos sobre as mentes e as práticas do mundo não europeu. Portanto, a partir da intensificação da presença ocidental na região da Ásia Oriental em meados do século XIX, China e Japão compreenderam o elevado grau de insegurança a que estavam submetidos, haja vista as estratégias de coerção utilizadas pelas potências europeias nos momentos de expansão. Sendo assim, as elites políticas de ambos os países tomaram a decisão de se adaptarem e adequarem suas instituições e estruturas à nova conjuntura vigente, absorvendo práticas e normas europeias.

Chineses e japoneses percebiam que o poder das potências ocidentais decorria de seu poderio econômico e militar, portanto estabeleceram o aumento do poder do Estado como prioritário. Ao final do século XIX, a China Qing conseguiu introduzir reformas pontuais, mas encontrou dificuldades por ter sido durante séculos o centro nervoso de um sistema regional, e o determinante das normas sociais desse sistema ${ }^{4}$. Além disso, a elite chinesa enxergava o padrão de interação europeu como bárbaro e contraditório - denominando-se civilizados, mas invadindo territórios de outras nações -, dificultando a aceitação do modelo de organização europeu como o ideal a emular (SUZUKI, 2009). Segundo Pumin (2014), os chineses patrocinaram um self-strenghning movement, que serviu apenas para preservar a dinastia Qing e que tinha o objetivo de fortalecer e modernizar as forças armadas do país, empenhando-se em fortalecer a ordem existente, agindo, então, de forma

3 Na obra Sobre a China, Henry Kissinger (2011) descreve de maneira esclarecedora as pressões das potências para abertura do país e as estratégias chinesas para lidar com os ocidentais.

4 A existência de um sistema interestatal asiático-oriental, ou um sistema sinocêntrico na Ásia, é discutida por Giovanni Arrighi na obra Adam Smith em Pequim (2008); Arrighi et al em The Resurgence of East Asia (2003); por Andre Gunder Frank na obra ReOrient (1998). 
oposta ao que se esperaria de uma China que estivesse em busca de se redefinir nos termos de um Estado moderno (PUMIN, 2014).

A elite japonesa da época enxergou no modelo europeu uma saída para se livrar da sensação de insegurança e da violência ocidental, e se lançou em um período de transformações intensas levadas adiante a partir da Restauração Meiji (1868). A adaptação japonesa teve alguns facilitadores: uma elite política mais aberta a reformas - haja vista a recente deposição do regime feudal pela liderança Meiji -, enquanto a liderança chinesa ainda trabalhava segundo a lógica institucional do Estado tradicional chinês; a menor extensão territorial japonesa colaborava para a implementação e efetividade das reformas, diferente da China com seu vasto território; ademais, havia no Japão um caráter ideológico nas reformas, que era o de fazer do país o centro da Ásia, posição ocupada antes pela China (SUZUKI, 2009). Esse processo de modernização, levado adiante pelo Japão, também internalizou a concepção europeia/ocidental de ordem internacional, assim como as práticas de caráter imperialista, expansionista e “civilizatório” (SUZUKI, 2009). Pode-se dizer que, nesse contexto, se deu a grande divergência entre China e Japão: o primeiro insistiu em um modelo institucional que já falhara ao conter o avanço ocidental, enquanto o segundo emulou seu “inimigo” e se aproveitou das vantagens alcançadas contra nações vizinhas. Logo, às potências ocidentais se somaria o Império Japonês, que buscava se estabelecer como potência e exigiria os mesmos privilégios comerciais e políticos cedidos pela China aos ocidentais.

A expansão japonesa na Ásia seria favorecida pelo contexto internacional do início do século XX. Na Europa, se vivenciava o declínio do equilíbrio de poder entre as potências - o que voltava a atenção dessas para a própria região, o que resultaria na deflagração da Primeira Guerra Mundial; posteriormente, o fracasso na busca por estabelecer uma ordem mundial pacífica no âmbito da Liga das Nações e o isolacionismo e resistência dos EUA em assumir o papel de potência no arranjo diplomático mundial. Com a atenção das potências voltadas ao Ocidente, o Japão teria maior liberdade para agir em sua região.

O Japão logo testou sua capacidade bélica - fruto da modernização que promovera - e se lançou em um processo de expansão territorial em conflitos com países vizinhos, entrando em guerra contra a China em 1894. Para Suzuki (2009), a Primeira Guerra Sino-Japonesa foi fundamentalmente um choque entre duas ordens internacionais; para Pumin (2014), foi uma competição significativa entre os dois países após uma geração de modernização, em que a derrota chinesa parecia inevitável, e que mudou a história do país. Tal conflito inaugurou uma 
série de agressões do Japão aos países vizinhos, entre eles a China, que ainda se refletem nas relações diplomáticas da atualidade. Tornou-se cada vez mais claro, com o passar das décadas, que o novo governo japonês cedera a um regime autoritário, dominado pela ala militar e por uma elite imperial, que intensificou ainda mais a violência contra os seus vizinhos asiáticos.

O Império do Japão foi à guerra contra o Império Chinês em 1894, acusando os chineses de violarem a Convenção de Tientsin de 1885 - que tratava da não interferência japonesa ou chinesa na política doméstica do então Reino da Coreia $^{5}$. A vitória japonesa sobre a China, em 1895, levou à subsequente sujeição e anexação da península coreana pelo Império Japonês por uma série de tratados no início do século $\mathrm{XX}^{6}$, abrindo caminho terrestre aos japoneses para o território chinês. Ao fim da guerra sino-japonesa, pelo Tratado de Shimonoseki ${ }^{7}$ (1895) o Império Chinês abdicara de qualquer tipo de influência sobre a península coreana, e foi obrigado a pagar indenizações de guerra ao Japão, conceder benefícios a comerciantes e navios em território e rotas fluviais chinesas de navegação, além de ceder ao Japão de forma perpétua a península de Liaodong e a ilha de Formosa (Taiwan). O Japão, assim como os ocidentais, tentara dividir o território chinês, e o papel do Japão na separação de Taiwan da China continental é lembrado até a atualidade.

Ao vencer a guerra contra a Rússia, em 1905, o Japão consolidou sua supremacia como potência no Leste Asiático. Com o vácuo deixado pelo Império Russo na região, a decadência da dinastia Qing e a recém-fundada República na China, e a guerra na Europa a partir de 1914, o Império Japonês desejou ir além e expandir seus domínios. Em segredo, os japoneses apresentaram aos chineses "Vinte e uma Demandas"8 que, em síntese, tinham o mesmo objetivo dos tratados de anexação da Coreia. O governo chinês, em posição inferior ao japonês nas negociações, aceitou grande parte das propostas - reconheceu a posição dominante

5 Uma versão na íntegra da Convenção de Tientsin de 1885 está disponível na página da National University of Singapore. Disponível em: < http://www.fas.nus.edu.sg/hist/eia/documents_archive/tientsin-convention.php > .

6 Os textos dos tratados entre Japão e Coreia estão disponíveis em: Tratado de Eulsa ou Tratado de Protetorado Japão-Coreia de 1905: < http://www.conservapedia.com/Eulsa_Treaty > ; Tratado de Anexação Japão-Coreia de 1907: < http://www.conservapedia.com/Japan-Korea_Annexation_Treaty_of_1907 > ; e o Tratado de Anexação Japão-Coreia de 1910: < http://www.conservapedia.com/Japan_Korea_Annexation_Treaty > .

7 O texto na íntegra do Tratado de Shimonoseki de 1895 pode ser encontrado em: < http://www.taiwandocuments. org/shimonoseki01.htm > .

8 Uma tradução e cobertura sobre o desenrolar das discussões sobre as demandas japonesas podem ser encontradas na página: < http://china.usc.edu/japanese-government- \% E2 \% 80 \% 9Ctwenty-one-demands \% E2 \% 80\% 9Dapril-26-1915> . 
do Japão na província de Shandong, no sul da Manchúria e na Mongólia Interior, além de aceitar a proibição de conceder ilhas e regiões costeiras a qualquer potência que não o Japão. Mas conseguiu rejeitar a demanda de entregar a administração chinesa a "conselheiros" japoneses (HUANG, 2015). Tais demandas japonesas foram tidas como outra humilhação contra o povo chinês, criando na população uma aversão significativa contra o Japão (HUANG, 2015). As agressões japonesas à China continuariam no decorrer das décadas.

Do ponto de vista doméstico japonês, a busca por transformar o país em potência demandava uma quantidade crescente de matérias-primas não suprida internamente. As reformas institucionais, econômicas, o esforço industrializante, o acentuado crescimento populacional, a construção e modernização da máquina de guerra, a proeminência dos militares no comando do país a partir da década de 1930, tais fatores impulsionaram os planos de expansão territorial do Império Japonês para a China e Sudeste Asiático (KENNEDY, 1987). Em 1931, o Japão iniciou a invasão da Manchúria e, em 1937, partiu violentamente para a conquista do território chinês, cujo episódio marcante foi a invasão da então capital chinesa Nanjing. O ataque a Nanjing pelos japoneses ficou conhecido por "Massacre" ou "Estupro", devido à violência perpetrada pelos soldados do exército imperial japonês, que saqueou e incendiou parte da cidade, promoveu execuções em massa de prisioneiros de guerra, além de torturar e assassinar milhares de civis - calculase que o exército japonês tenha executado entre 200 mil e 300 mil pessoas apenas em Nanjing. Entre os civis torturados e mortos na antiga capital, calcula-se que os japoneses estupraram de 20 mil a 80 mil mulheres chinesas, levando muitas à morte por ferimentos relacionados à violência sexual, ao suicídio ou a danos psicológicos graves (CHANG, 1998). O massacre em Nanjing9 foi apenas um episódio da invasão japonesa, que segundo Iris Chang10 - utilizando números de R. J. Rummel (1991) -, causou um total de mais de 19 milhões de mortes, diretas (assassinatos) e indiretas (como mortes por fome, doenças causadas por saques, bombardeios, experiências médicas).

A China esteve submetida durante cinco décadas à hostilidade japonesa - se levarmos em conta que essa se iniciou com a Primeira Guerra Sino-Japonesa, em

9 O massacre em Nanjing também foi tema de diversas obras cinematográficas, como City of Life and Death, de Lu Chuan (2009); The Flowers of War, de Zhang Yimou (2011); Nanking, de Bill Guttentag e Dan Sturman (2007).

10 Em sua obra The Rape of Nanking (1998), Iris Chang faz uma investigação minuciosa e interessante sobre o massacre japonês em Nanjing, colhendo documentos oficiais, jornais e filmagens da época, depoimentos de sobreviventes chineses e ex-soldados japoneses, assim como busca entender os motivos que levaram à violência sádica japonesa durante a invasão da China. 
1894, e se encerrou apenas com a rendição e retirada japonesa em 1945, quando se encerrou a Segunda Guerra Sino-Japonesa e o Japão foi obrigado a abdicar e retirar suas tropas do território chinês. Cinco décadas de submissão à "humilhação" japonesa se tornaria um forte elemento formador do nacionalismo chinês nas décadas posteriores, um elemento que, inclusive, vem se intensificando nessas últimas décadas.

\section{O sentimento anti-Japão fomentado}

Além da invasão pelos japoneses, a sociedade chinesa ainda encarava os problemas políticos domésticos do país. O fim da combalida dinastia Qing, a fundação da frágil República da China em 1912, uma intensa disputa pelo comando do país entre nacionalistas do Kuomintang e comunistas do Partido Comunista chinês, seriam fatores que comprometeriam a estabilidade doméstica e a unidade nacional. A China só poderia "respirar” após o sucesso da Revolução Chinesa e a fundação da República Popular da China, em 1949, tendo o Partido Comunista chinês vencido os nacionalistas na disputa pelo comando do país, e esses últimos se retirado para a ilha de Taiwan. Nas décadas posteriores à fundação da República Popular, o Partido Comunista chinês se ocupou da tarefa de reconstruir o país e fazer uma nova China, seguindo o objetivo de construir uma China socialista e moderna ${ }^{11}$.

Nessa fase inicial de estabelecimento da República Popular, o P.C. chinês poderia reivindicar a sua legitimidade como governante em duas bases, na ideologia marxista-leninista e no nacionalismo - e.g. focando na luta de classes representada pela disputa entre nacionalistas/capitalistas e comunistas, e argumentando ser o único responsável pela vitória sobre os japoneses, por isso sua "legitimidade patriótica” de estar no poder (CUI, 2012). Mas a preocupação primordial do Partido Comunista em se estabelecer como único governante legítimo do país contra o Kuomintang e construir o socialismo chinês parecem ter sido mais importantes nesse momento do que rememorar os episódios históricos da agressão japonesa (ZHANG; WEATHERLEY, 2013).

11 Para maiores detalhes sobre a história da Revolução Chinesa e o desenvolvimento político e econômico da República Popular da China, consultar: A Revolução Chinesa, de Wladimir Pomar (2004); A Construção do Socialismo na China, de Daniel Aarão Reis Filho (1982). 
Ainda assim, a figura do invasor japonês esteve presente na memória chinesa desde o pós-guerra, sobretudo nos discursos de retórica anti-imperialista. A maneira como os políticos chineses utilizaram essa figura variou em intensidade de acordo com o tempo e conjuntura doméstica. A construção social e transmissão de uma memória coletiva sobre a agressão japonesa - memória construída a partir de memórias vividas pela população somadas a memórias mediadas por representações, institucionalmente moldadas por processos de seleção e exclusão, lembranças ou “esquecimentos" - tiveram grande importância no desenvolvimento da relação sino-japonesa (CUI, 2012). Podemos dividir essa memória em duas fases: uma, quando ela esteve sob controle majoritário do Estado e, outra, quando o Estado passa a perder gradualmente o monopólio quase exclusivo sobre ela - na primeira, predomina o nacionalismo estatal (proposto por políticos e líderes em geral que almejam reforçar sua legitimidade, apelando ao patriotismo do povo) e, na segunda, quando predomina o nacionalismo popular (aquele impulsionado por intelectuais, jornalistas e escritores e focado em debates sobre história, cultura, "valores" nacionais etc.) (ROSE, 2000).

Naquela primeira fase, dentro da lógica do discurso do nacionalismo antiimperialista e das experiências recentes, o P.C. e o governo chinês utilizaram de representações e campanhas pedagógicas, como filmes e músicas, para fomentar o patriotismo nacional. Um dos componentes dessa propaganda era a memória da agressão japonesa e a narrativa vitoriosa do partido como "herói” triunfante no objetivo de livrar a China das garras dos "demônios japoneses”. Entre os recursos de propaganda, estavam filmes como Mine Warfare (1962) e Tunnel Warfare (1965), que retratam de maneira cômica a guerra de resistência contra o Japão e demonstram com clareza os tipos de personagens objetivados: um invasor japonês de estereótipo tolo, o traidor chinês que deveria ser desprezado e o guerrilheiro comunista como o herói inteligente (CUI, 2012; ZHANG; WEATHERLEY, 2013) filmes que são um exemplo da mescla de memória vivida com memória mediada institucionalmente. Mas aquele era um momento histórico particular, onde a ideologia marxista-leninista-maoísta ainda era forte componente da legitimidade do governo comunista, e esse governo tinha controle dos meios de informação e de educação. Em tal contexto, os líderes chineses utilizavam a educação patriótica, com elementos anti-Japão, destinada principalmente para fins políticos domésticos, e não um público externo (HE, 2007). Como resultado dessa memória histórica, estabeleceu-se uma imagem negativa do Japão na mentalidade de grande parte da população chinesa que viria à tona no futuro. 
Ao mesmo tempo em que fomentava o patriotismo internamente, o governo chinês adotava uma política externa pragmática, visando quebrar o isolamento do país - aprofundado após a ruptura sino-soviética no inicio da década de 1960 e os atritos com o vizinho comunista do norte. Tal pragmatismo é demonstrado na reaproximação e normalização das relações entre a República Popular com Estados Unidos e Japão durante a década de 1970. Durante o processo de normalização da relação com o Japão, o Estado chinês adotou uma política de separar o caráter majoritariamente pacífico da população japonesa do caráter perverso de poucos líderes do período da guerra (CUI, 2012). Durante o processo de normalização, o premier Zhou Enlai descreveu o povo japonês como pacífico e deu pouca atenção à questão da propriedade territorial de pequenas ilhas inabitadas localizadas entre Okinawa e Taiwan, chamadas Diaoyu em chinês e Senkaku em japonês ${ }^{12}$. O então primeiro-ministro chinês apontou que a questão da posse do arquipélago não era um problema quando comparado à recuperação de relações diplomáticas normais - questão que mais tarde provocaria intensas disputas entre os dois países (HE, 2007). Outra medida tomada para promover a normalização da relação sinojaponesa foi a renúncia chinesa por reparações de guerra por parte do Japão, como consta no comunicado conjunto entre os dois países de 1972 (JAPAN, 1972). O objetivo desse pragmatismo era conseguir do Japão o reconhecimento da República Popular da China como governo legítimo chinês, estimular o comércio bilateral e formar um alinhamento estratégico frouxo contra a União Soviética, todos objetivos concretizados (JAPAN, 1972). Na realidade, a normalização das relações com o Japão veio ao custo da omissão de fatos históricos da guerra entre os dois países, sem que houvesse um reconhecimento histórico mútuo sobre o que realmente aconteceu durante o conflito,

impediu a investigação rigorosa dos fatos históricos, e gestos políticos substituíram a restituição sincera e concreta. A tentativa de Pequim de criar uma ilusão de amizade sino-japonesa nos anos 1970 sem antes resolver a conta histórica foi muito bem sucedida. A maioria dos jovens chineses da época tinha um conhecimento mínimo sobre as atrocidades japonesas de guerra, pois os livros didáticos controlados pelo Estado raramente as mencionavam e a pesquisa acadêmica sobre esse tema foi banida. No entanto, histórias privadas sobre os "demônios japoneses" sobreviveram, mas apenas dentro

12 Tal arquipélago está localizado no Mar da China Oriental, a uma distância de aproximadamente 190 quilômetros a nordeste de Taiwan, a cerca de 290 quilômetros a oeste de Okinawa (Japão) e a aproximadamente 400 quilômetros da China continental. É formado por oito ilhas desabitadas que atualmente estão sob controle japonês. 
de famílias e pequenas comunidades. Além disso, devido ao firme controle dos meios de comunicação de massa naquele período, a população chinesa não possuía meios para conhecer o tratamento falso dado pelo Japão sobre a história da guerra, tal como o discurso acima mencionado proferido por Tanaka na Dieta, a omissão dos crimes de guerra nos livros didáticos e as visitas de líderes políticos ao Santuário de Yasukuni ${ }^{13}$ que posteriormente se tornou o ponto focal da discordância política sino-japonesa. (HE, 2007, p. 6 - tradução nossa) ${ }^{14}$

A fase majoritariamente positiva da relação seria passageira e a década de 1980 trouxe mudanças importantes na utilização do nacionalismo na China. O declínio progressivo da ideologia marxista-leninista nas décadas posteriores às políticas de reforma e abertura econômica levaram o Estado chinês e o Partido Comunista a progressivamente utilizarem o nacionalismo para preencher esse vazio ideológico e diversificar as bases de sua legitimidade (CUI, 2012; EKMAN; PAJON, 2015; YUAN, 2008; ZHANG; WEATHERLEY, 2013).

Quando a população chinesa passou a aceitar a amizade sino-japonesa, o governo chinês renovou a narrativa da guerra, na década de 1980. Isso ocorreu devido ao declínio da ideologia comunista já mencionado, e ao fato de que as reformas do então governo de Deng Xiaoping sofriam forte oposição da ala mais conservadora do Partido Comunista chinês e de parte da população que sentia os efeitos negativos das reformas que tomavam curso. Então, na nova estrutura de ideias legitimadoras do Partido que se estabelecera, o patriotismo passaria a ter função principal, onde se pregaria o amor pela nação e a grandeza da China, assim como o Partido Comunista se afirmaria como guardião do patriotismo.

13 O Santuário de Yasukuni foi criado em 1869, com o objetivo de “confortar os espíritos" e honrar a memória daqueles que lutaram e morreram pela causa imperial, entre eles os soldados japoneses mortos em guerra. Dentre os soldados homenageados, estão criminosos de guerra Classe A - julgados pelo Tribunal de Crimes de Guerra de Tóquio - que foram consagrados em 1978, entre eles o General Hideki Tojo. Por honrar a memória de tais indivíduos, o local é alvo de críticas dos países invadidos pelo Japão durante a Segunda Guerra Mundial. Governos da Coreia do Sul e China, por exemplo, alegam que as homenagens feitas a criminosos de guerra no santuário denotam um caráter nacionalista e militarista ainda presentes na sociedade japonesa. O local também abriga o museu militar Yushukan (SOUZA, 2015).

14 "prevented rigorous investigation of historical facts, and political gestures substituted sincere, concrete restitution. Beijing's attempt to create an illusion of Sino-Japanese friendship in the 1970s without first settling the historical account was largely successful. Most young Chinese at that time had minimal knowledge about Japanese war atrocities, for the state-controlled textbooks rarely mentioned them and academic research on this topic was banned. Private stories about the 'Japanese devils' nevertheless survived, but only within families and small communities. Moreover, because of the tightly controlled mass media at the time, ordinary Chinese people had no way to learn about Japan's false treatment of the war history, such as the aforementioned speech in the Diet by Tanaka, textbook cover-up of war crimes, and leaders' worship at the Yasukuni Shrine that later became the focal point of Sino-Japanese political contention” (HE, 2007, p. 6). 
A narrativa principal da guerra passou do conflito entre nacionalistas e comunistas para a resistência chinesa às invasões estrangeiras, sobretudo a invasão japonesa (HE, 2007). Os efeitos de se desconsiderar um entendimento histórico mútuo sino-japonês sobre os fatos da guerra tornaram-se evidentes a partir de então.

Em meados da década de 1980, o governo chinês passa a lançar campanhas patrióticas e instruir que as escolas primárias e secundárias enfatizassem o ensino da história de resistência à agressão estrangeira como uma forma de lembrar aos estudantes as lições históricas e para que não esquecessem a invasão imperialista e a heroica resistência do povo chinês. Os livros didáticos passam a "reabilitar" o papel do partido nacionalista Kuomintang na resistência ao Japão, enquanto passam a relatar de forma mais abrangente os crimes de guerra japoneses, com descrições vívidas, depoimentos de vítimas e imagens explícitas das crueldades. Museus são construídos em importantes locais do conflito e designados como bases de educação patriótica, como o Nanjing Massacre Memorial Hall e o museu da Unidade 731, em Harbin; com permissão e apoio governamental, são efetuadas pesquisas históricas aprofundadas sobre o período de guerra; são produzidos filmes sobre o conflito, como os que relatam o massacre de Nanjing e os experimentos médicos feitos em prisioneiros de guerra ${ }^{15}$ (HE, 2007).

O primeiro efeito popular dessa nova abordagem legitimadora do Estado chinês e sobre sua base histórica referente à guerra contra o Japão verificou-se em 1982, com a questão do tratamento sobre a história da guerra nos livros didáticos japoneses. Tal questão emergiu após a mídia japonesa divulgar que o Ministério da Educação japonês recomendara mudanças a historiadores e editores de livros didáticos de história. A instrução era eliminar, reformular ou atenuar passagens relacionadas com as ações japonesas durante o período colonial e de guerra na Ásia - mudanças quanto à descrição da "invasão da China” (trocada por "avanço sobre a China”) pelo Japão e descrições sobre o Massacre de Nanjing. A mídia de diversos países asiáticos reproduziu e reforçou as críticas da mídia japonesa, e o governo chinês fez um protesto oficial demandando que os livros didáticos fossem corrigidos. O governo chinês argumentou que, ao minimizar ou omitir a natureza das ações japonesas durante a guerra contra a China, o governo do Japão não adotava uma visão correta da história, algo prejudicial para as relações sinojaponesas. A imprensa chinesa promoveu, durante dois meses, comentários de líderes de organizações de massa (como China-Japan Friendship Association, China

15 Nanjing Massacre (1982), Bloody Testimony of Massacre in a Captured City (1987), Men Behind the Sun (1988) (HE, 2007). 
Education Society, All-China Youth Federation), juristas e acadêmicos chineses; entrevistas com sobreviventes e testemunhas da conduta japonesa; programas televisivos mostraram imagens das atrocidades; foram realizadas exposições fotográficas retratando os acontecimentos da guerra em diversas cidades da China. A atitude do governo japonês foi encarada como uma distorção e "embelezamento" da história da guerra (ROSE, 2005). Foi a primeira vez, desde a guerra, que a China contestou, ou teve problemas, com os pontos de vista históricos do Japão (HE, 2007), e tais discordâncias se intensificariam no decorrer das décadas.

Ainda durante a década de 1980, protestos do governo e da população chineses voltaram a ocorrer por ações e políticas japonesas: em 1985, contra a visita do primeiro-ministro japonês Yasuhiro Nakasone à Yasukuni e protestos estudantis devido ao grande fluxo de produtos japoneses no mercado doméstico chinês, o que foi chamado de "segunda invasão japonesa"; a questão sobre livros didáticos de história no Japão teria outro capítulo no ano de 1986; o aumento dos gastos em defesa do Japão e a tensão devido ao desequilíbrio comercial contínuo entre os dois países em 1987; declarações controversas sobre a guerra por parte de líderes políticos japoneses em 1988 e 1989 (ROSE, 2005). Embora o Estado chinês tenha mantido a postura de distinguir a população japonesa dos líderes que levaram o Japão à guerra - buscando evitar um antagonismo contra o Japão, com quem a cooperação econômica já se tornara importante para os interesses nacionais chineses -, os protestos populares na China demonstravam que parecia estar se substanciando na mentalidade da população chinesa a crença na culpa coletiva ou na "maldade" de toda nação japonesa durante a guerra. Além disso, movimentos civis chineses, que reivindicavam reparações de guerra do governo e de corporações japonesas, começaram a ganhar força nos anos finais da década de 1980, compostos por sobreviventes chineses de agressões diversas, como de trabalhos forçados, exposição a armas químicas, escravização sexual (CUI, 2012; HE, 2007) - reparações de que o governo chinês abdicara quando houve a normalização das relações sino-japonesas. Tais atritos seriam interpretados como naturais, não tivessem se originado após a normalização das relações, demonstrando que, ao ignorar a resolução de controvérsias históricas como fator crucial na normalização, o conflito findado em 1945 ainda lançaria sombras sobre o futuro da relação.

No início dos anos de 1990, o governo comunista chinês avançou com maior rapidez na disseminação de uma campanha de educação patriótica nas escolas ${ }^{16}$,

16 Para maiores detalhes sobre a educação patriótica, tanto na China quanto no Japão, consultar Sneider, 2013. 
com o objetivo de fornecer aos jovens chineses uma versão da história que reduzia a importância da narrativa da era maoísta da luta de classes dentro da China, em favor de uma versão que representava a China como vítima da humilhação e brutalidade das potências estrangeiras, como afirma Sneider:

Agora a ênfase está na unidade nacional, embora liderada pelos comunistas, contra o inimigo estrangeiro. A afirmação do papel da China como arquiteto da derrota japonesa agora é central, juntamente com a vitimização da China nas mãos de um invasor brutal e criminoso. É uma narrativa que se adequa à mobilização nacionalista de uma população não mais motivada pela ideologia neocomunista. (SNEIDER, 2013, p. 41 - tradução nossa) ${ }^{17}$

Muitos intelectuais chineses, durante a década de 1990, argumentavam abertamente que o marxismo-leninismo já não era um meio efetivo de garantir lealdade e prevenir a desintegração da sociedade chinesa, apontando que o país deveria se basear firmemente sobre o nacionalismo, capaz de fornecer a base para a coesão nacional e integração política (CUI, 2012). As campanhas de educação patriótica promovidas pelo Estado chinês facilitaram a emergência de um forte nacionalismo cultural (ou nacionalismo popular) durante a década de 1990, pois se produziu um ambiente mais relaxado e propício para debates sobre a história e a identidade nacional (ROSE, 2000). Uma série de publicações e revistas de caráter nacionalista e antiocidental ganharia espaço durante a década de 1990. A introdução da internet e sua popularização nos anos 2000 trouxe a possibilidade para que parte da sociedade chinesa, educada segundo a educação patriótica iniciada nos 1980, pudesse se expressar e se comunicar, uma ferramenta ideal para a construção e reconstrução da memória coletiva em escala massiva. O ciberespaço chinês se transformaria rapidamente em uma plataforma popular efetiva de mobilização nacionalista, particularmente de um nacionalismo antiJapão (CUI, 2012).

Na década de 1990, o peso das divergências históricas continuaria, mas um novo fator ganharia peso: a disputa territorial pelo arquipélago Diaoyu/Senkaku, mencionado anteriormente. Mais uma questão deixada de lado durante o processo de reaproximação entre China e Japão veio à tona para desestabilizar a relação

17 "Now the emphasis is on national unity, though led by the Communists, against the foreign foe. The assertion of China's role as the architect of Japan's defeat is now central, along with China's victimization at the hands of a brutal and criminal invader. It is a narrative that suits the nationalist mobilization of a populace no longer motivated by neo-Communist ideology" (SNEIDER, 2013, p. 41). 
diplomática sino-japonesa. A reivindicação, pelos dois países, sobre a soberania das ilhas seria fomentada pela presença de recursos energéticos no leito marítimo da região disputada, além de possibilitar ao país que as controlasse a expansão de sua Zona Econômica Exclusiva18. Mas os sentimentos seriam inflamados por grupos nacionalistas de ambos os países: ora grupos japoneses desembarcaram nas ilhas, ora grupos chineses, levando os dois governos a se expressarem de forma assertiva sobre a soberania das ilhas. A disputa territorial se tornou problema recorrente, tendo gerado crises entre os dois países em 1990, 1996, 2004-2005, 2010 e $2012^{19}$ (BEUKEL, 2011). Durante as crises dos 1990, o governo chinês ainda possuía maior controle sobre os meios de informação e conseguiu promover blackouts midiáticos, visando evitar protestos e conter uma escalada da disputa que ofuscasse as boas relações bilaterais sino-japonesas - nesse período, os grupos nacionalistas chineses tinham como base Hong Kong e Taiwan, onde os protestos aconteciam (BEUKEL, 2011)). A situação mudou nos anos 2000, quando parte expressiva da população chinesa passou a ter a internet como fonte de informações e ferramenta de expressão - o número de usuários de internet na China saltou de cerca de 22 milhões em 1997 para 298 milhões em 2008 (CUI, 2012), tendo alcançado cerca de 688 milhões de usuários em 2016, segundo órgão responsável do Estado chinês (CHINA, 2016).

\section{Reflexos do sentimento anti-Japão na relação bilateral}

A abertura e diversificação midiática na China possibilitaram maior liberdade de expressão e difusão de informações sobre ressentimentos e inquietações populares. Assim, notícias negativas sobre o Japão, com potencial para provocar sentimentos antijaponeses, podem ser obtidas por fontes alternativas de informação, além daquelas oficiais. O público chinês também está mais bem informado sobre as negociações diplomáticas entre os dois países, fator que causa pressão sobre o governo chinês quando se busca acordos e compromissos. Após ser intensamente exposta, com a campanha de educação patriótica, a detalhes

\footnotetext{
18 Para mais detalhes sobre origem, afirmações e controvérsias da disputa pelo arquipélago Diaoyu/Senkaku, consultar: Thomas A. Hollihan, The Dispute over the Diaoyu/Senkaku Islands (2014); Zhongqi Pan, Sino-Japanese Dispute over the Diaoyu/Senkaku Islands (2007); Shin Kawashima, The Origins of the Senkaku/Diaoyu Islands Issue (2013).

19 Para uma descrição detalhada dessas crises, consultar Beukel, 2011.
} 
das atrocidades cometidas pelo exército japonês durante a guerra, a sociedade chinesa se tornou altamente receptiva e reativa a notícias ou rumores negativos que envolvam o Japão ou a sociedade japonesa (HE, 2007). O número crescente de páginas nacionalistas e de mensagens anti-Japão se expandiram com o uso da internet e a popularidade de redes sociais como o SinaWeibo, além de facilitarem o encontro entre nacionalistas que antes estavam isolados, possibilitaram a proliferação de grupos de discussão nacionalistas, em parte explicando o reforço dos sentimentos negativos quanto ao Japão (EKMAN; PAJON, 2015). Tornou-se usual a elaboração de petições online de grupos chineses com demandas variadas - e.g. no ano 2003 mais de um milhão de chineses responderam a uma petição que demandava desculpas e compensações do Japão por cidadãos feridos devido ao vazamento de armas químicas deixadas em território chinês após o término da guerra; no mesmo ano, uma petição online pedindo o boicote de uma marca de cerveja japonesa conseguiu 1,28 milhões de assinaturas em duas horas; ainda em 2003, cerca de um milhão de chineses assinaram, em dez dias, uma petição contra a participação de empresas japonesas na construção de trens de alta velocidade na China; em 2005, mais de dez milhões assinaram petição contra a campanha japonesa pelo assento permanente no Conselho de Segurança da ONU (EKMAN; PAJON, 2015).

Tal sentimento negativo quanto ao Japão ficou evidente nas reações populares às crises sobre o arquipélago Diaoyu/Senkaku nos anos de 2004-2005, 2010 e 2012, quando os protestos passaram a crescer em números a cada crise diplomática. A colisão na região disputada de embarcações chinesas com embarcações da marinha japonesa em 2004 (ASIA TIMES, 2004; BBC, 2005) e 2010 (WASHINGTON POST, 2010) e a detenção dos tripulantes chineses geraram uma onda de protestos anti-Japão por toda a China (CHINA DAILY, 2005; LA TIMES, 2010). Protestos coordenados pela internet, sem liderança clara, levaram centenas de milhares a protestarem em mais de quarenta cidades chinesas durante semanas, havendo protestos diante da embaixada do Japão em Beijing e ataques a estabelecimentos comerciais de origem japonesa em várias cidades da China (BEUKEL, 2011). Manifestações do tipo se repetiram em maior escala no ano de 2012, após o Estado japonês nacionalizar algumas ilhas do arquipélago - comprando-as de um proprietário particular japonês (REUTERS, 2012). Novamente, a violência foi demonstrada contra empresas de origem japonesa boicotadas e atacadas, assim como contra a embaixada japonesa em Beijing (CS MONITOR, 2012). Devido ao aumento da violência nos protestos populares, o governo chinês passou a interferir 
e buscar conter as manifestações. Campanhas de "patriotismo racional" foram divulgadas pelo governo e mídia oficial, afirmando ser necessário sabedoria na expressão do patriotismo, não devendo ser perturbada a ordem social do país (XINHUA, 2012). Medidas para conter a propagação de atos violentos foram tomadas (CS MONITOR, 2012a), como o controle de mídias sociais e programação de TV, campanha interna do Partido Comunista para que membros do governo não incentivassem as manifestações, prisões, publicidade de julgamentos e condenações de manifestantes que cometeram violência (EKMAN; PAJON, 2015).

Yinan He (2007) aponta o caso do projeto da ferrovia de alta velocidade BeijingShanghai como uma ilustração para o potencial dano às relações econômicas bilaterais que o nacionalismo e o sentimento anti-Japão da população chinesa podem causar. Após anos de debates sobre qual tecnologia se adaptaria melhor às necessidades chinesas, em 2003 a tecnologia do shinkansen japonês parecia ser a mais cotada a ser adotada no projeto de US $\$ 15$ bilhões. A perspectiva de que a tecnologia japonesa seria a vencedora da licitação foi veiculada em jornais de Hong Kong e petições online começaram a ganhar assinaturas em oposição à possível escolha do "trem-bala" japonês, devido às resistências do Japão quanto ao reconhecimento das agressões passadas (HE, 2007). Uma campanha nacionalista na internet foi organizada com o logotipo: “Céu e Terra não tolerarão traidores. Nós não queremos o trem-bala japonês. Nós nos recusamos à utilização de produtos japoneses na linha Beijing-Shanghai”, tendo a petição lançada por tal grupo alcançado noventa mil assinaturas em uma semana (GRIES, 2005). Para Yinan He, a pressão pública obrigou o governo chinês a reconsiderar as consequências políticas da decisão de adotar a tecnologia japonesa. Quando a ministra dos Transportes do Japão viajou à China para reforçar a proposta japonesa, não conseguiu se reunir com o primeiro-ministro chinês Wen Jiabao ou funcionários de alto escalão do Ministério das Ferrovias da China. Segundo He, Beijing deixou claro que, apesar dos aspectos técnicos e financeiros, o fator político também era importante na tomada de decisão. Durante a visita de uma delegação do parlamento japonês à China, o vice-ministro de Relações Exteriores da China sugeriu que seria necessário excluir o Japão do projeto devido à pressão da opinião pública, alegando que a China enfrentava um alto sentimento anti-Japão, e que, caso o governo adotasse a tecnologia do shinkansen, o povo chinês teria uma opinião negativa (HE, 2007).

Como demonstrado pelo caso acima, esse sentimento anti-Japão, que permeia parte da sociedade chinesa, gera consequências que vão além do descontentamento da população com o país vizinho, afetando a relação comercial entre os dois países 
no auge das crises diplomáticas. Como exemplo, relatórios do Bank of Japan²0, referentes ao segundo semestre de 2012 - o auge da crise pela nacionalização das ilhas mencionadas acima -, apontam que as discordâncias bilaterais foram responsáveis por uma queda drástica na exportação de veículos japoneses para a China. Segundo relatório da Japanese External Trade Organization (JETRO), de setembro a dezembro de 2012, a venda de automóveis produzidos no Japão para a China sofreu uma queda de $63 \%$ quando comparada com o mesmo período do ano anterior. As manifestações contra políticas japonesas foram um dos principais motivos citados para que tal queda acontecesse (JAPAN, 2013). A queda nas exportações de veículos para o mercado chinês se deve, em parte, ao boicote de cidadãos chineses às empresas automotivas japonesas (TOKYO TIMES, 2012).

Houve também uma diminuição no número de turistas chineses que viajaram ao Japão no segundo semestre de 2012. Quando observados atentamente, os dados disponibilizados pela Japan Tourism mostram uma expressiva queda dessas viagens a partir de setembro de 2012, quando os desentendimentos bilaterais se agravaram, contrariando as tendências dos meses e anos anteriores. Na comparação mensal entre os anos de 2011 e 2012, houve aumento de turistas chineses que visitaram o Japão em todos os meses até setembro de 2012 e, a partir de outubro, há uma queda expressiva no comparado dos meses ano a ano (JAPAN TOURISM, 2013). Além de queda na demanda, agências de viagens chinesas cancelaram voluntariamente os pacotes de turismo que já haviam sido vendidos com destino ao país vizinho (BLOOMBERG, 2012). Possíveis boicotes chineses ao turismo no Japão podem ter impactos significativos no setor, uma vez que os chineses estão entre as nacionalidades que mais visitam e gastam no Japão - em 2015, foram a nacionalidade que mais visitou o arquipélago japonês, correspondendo a um quarto do total de visitantes estrangeiros e, de longe, os turistas que mais gastam no mercado japonês, sendo responsáveis por 40,8\% do total de gastos por turistas estrangeiros no Japão (JAPAN TIMES, 2016; JAPAN TOURISM, 2016).

Estatísticas disponibilizadas pela pesquisa The 11th Japan-China Public Opinion Poll, sobre as impressões mútuas entre os dois povos, demonstram o aumento da impressão negativa da população chinesa sobre o Japão desde 2007. No ano de 2013 - após a nacionalização de ilhas do arquipélago Diaoyu/Senkaku -, a impressão negativa sobre o Japão foi citada por cerca de $93 \%$ dos entrevistados

20 Os relatórios do Bank of Japan (BoJ), onde analistas apontam os efeitos dos atritos diplomáticos na economia e turismo no ano de 2012, podem ser encontrados no Monthly Report of Recent Economic and Financial Developments, December 2012. Disponível em: < http://www.boj.or.jp/en/mopo/gp_2012/gp1212b.pdf > . 
chineses, havendo um recuo nessa percepção nos anos seguintes, atingindo $78 \%$ em 2015. Quando questionados sobre as razões para a impressão desfavorável em relação ao Japão, cerca de $70 \%$ dos chineses entrevistados mencionaram a falta de remorso e de um pedido de desculpas adequado do Japão no tocante à história da invasão da China; a nacionalização japonesa das ilhas do arquipélago Diaoyu/Senkaku também foi lembrada por cerca de $68 \%$ dos entrevistados, sendo essas duas razões proeminentes em comparação às demais. Quando perguntados sobre as principais barreiras para o desenvolvimento da relação bilateral, as razões mais citadas pelos chineses foram a questão territorial e o entendimento e ensino da história no Japão; para $47 \%$ dos chineses entrevistados, a relação entre os dois países não se desenvolverá se as questões históricas não forem resolvidas (GENRON NPO; CHINA DAILY, 2015).

Após os violentos protestos antijaponeses de 2012, é perceptível a postura mais cautelosa do governo chinês ao tratar das questões históricas com o Japão, supostamente como medida para evitar atos de violência e vandalismo como os vistos outrora. Desde então, ao se manifestar sobre questões históricas, a chancelaria chinesa tem declarado que tais questões têm uma relação direta com a base política da relação bilateral, recordando o sofrimento causado pelo militarismo japonês, apontando a necessidade de que o Japão encare esse período e mantenha em mente as lições da história, permitindo que o país desenvolva boas relações com a região. Tal cautela pode ser um dos fatores responsáveis pelo recuo da percepção negativa da população chinesa sobre o Japão desde 2012, que podemos caracterizar como o período de maior tensão na relação bilateral recente.

A questão histórica pendente entre China e Japão se torna mais preocupante em um contexto de transformações de ordem regional e mundial em que as duas nações buscam assegurar sua relevância, tendendo a aumentar as desconfianças recíprocas sobre questões militares. A recente expansão e modernização das Forças Armadas chinesas geram apreensão entre os japoneses pela dúvida sobre qual seria a postura de uma China hegemônica e com uma sociedade com forte sentimento antijaponês. Por outro lado, a China se inquieta sobre a possibilidade de uma remilitarização do Japão - com uma eventual queda ou reinterpretação da constituição pacifista do país - que leve novamente o país a condutas agressivas contra seus vizinhos asiáticos. Embora a importante relação econômica bilateral mantenha-se estável e a relação diplomática esteja se normalizando nos últimos anos, ao que parece, pouco tem sido feito ou divulgado pelos dois Estados para superar as discordâncias referentes à história da guerra. Os problemas recentes da 
relação sino-japonesa são, em grande parte, reflexos da escolha política de deixar de lado o esclarecimento dos fatos históricos e a resolução de controvérsias sobre tais fatos no processo de reaproximação durante a década de 1970. Ao não se criar entre os dois povos uma versão comum sobre a história do conflito que os envolveu, abriu-se o precedente para que grupos dentro dos dois Estados criassem versões dos fatos que estivessem de acordo com seus interesses. Em um contexto de desenvolvimento e avanço das redes de informação e comunicação, em que o nacionalismo popular ganha forças e capacidade de mobilização devido ao seu alcance, a solução das divergências históricas se tornou um desafio ainda maior e urgente. Como verificado, postergar um acordo sobre tais desentendimentos amplia o risco de que as relações bilaterais deteriorem, ameaçando não apenas a estabilidade econômica entre os dois países, mas a segurança e a economia regionais.

\section{Referências}

ACHARYA, Amitav; BUZAN, Barry. Why is there no non-Western international relations theory? An introduction. In: ACHARYA, A.; BUZAN, B. (Edit.). Non-Western International Relations Theory Perspectives on and beyond Asia,. London: Routledge, 2010, p. 1-26.

ARRIGHI, G.; HAMASHITA, T.; SELDEN, M. The Ressurgence of East Asia: 500, 150 and 50 year perspectives. London: Routledge Curzon, 2003.

ARRIGHI, Giovanni. Adam Smith em Pequim: origens e fundamentos do século XXI. São Paulo, Boitempo Editorial, 2008.

ASIA TIMES. New Sino-Japanese strain over disputed islands. Asia Times Online, 27 mar. 2004. Disponível em: < http://www.atimes.com/atimes/Japan/FC27Dh01.html > . Acessado em: 05/05/2016.

BBC. Thousands join anti-Japan protest. BBC News, 16 abr. 2005. Disponível em: < http://news.bbc.co.uk/2/hi/asia-pacific/4450975.stm > . Acessado em: 05/05/2016.

BEUKEL, Erik. Popular Nationalism in China and the Sino-Japanese Relationship: the conflict in the East China Sea an introductory study. DIIS Report, Danish Institute for International, Copenhagen, n.01, 2011.

BLOOMBERG. Japan Sees 20\% Drop in China Tourism as Islands Row Heats Up. Bloomberg News, 13 set. 2012. Disponível em: < http://www.bloomberg.com/news/2012-09-13/ japan-fears-20-drop-in-china-tourists-as-islands-spat-heats-up.html > . Acessado em: $09 / 05 / 2016$. 
CHANG, Iris. The Rape of Nanking: the forgotten holocaust of World War II. New York: Basic Books, 1998.

CHINA. The 37th Statistical Report on Internet Development in China. China Internet Network Information Center (CNNIC). Disponível em: < http://cnnic.com.cn/IDR/ ReportDownloads/ > . Acessado em: 17/03/2016.

CHINA DAILY. 42 held for protest property damage. China Daily, 27 abr. 2005. Disponível em: < http://www.chinadaily.com.cn/english/doc/2005-04/27/content_437776.htm > . Acessado em: 05/05/2016.

CS MONITOR. Japanese shops, factories close in China after violence. The CS Monitor, 17 set. 2012. Disponível em: < http://www.csmonitor.com/Business/Latest-NewsWires/2012/0917/Japanese-shops-factories-close-in-China-after-violence > . Acessado em: 06/05/2016.

CS MONITOR. China moves to quell anti-Japanese demonstrations. The CS Monitor, 17 set. 2012a. Disponível em: < http://www.csmonitor.com/World/2012/0917/ China-moves-to-quell-anti-Japanese-demonstrations > . Acessado em: 06/05/2016.

CUI, Shunji. Problems of Nationalism and Historical Memory in China's Relations with Japan. Journal of Historical Sociology, Oxford, v.25, n.2, June 2012 p.200-222.

EKMAN, Alice; PAJON, Céline. Nationalism in China and Japan and Implications for Bilateral Relations. Asie.Visions -Institut Français des Relations Internationales (Ifri). Paris, March 2015.

FRANK, Andre Gunder. ReORIENT: global economy in the Asian Age. Los Angeles: University of California Press, 1998.

GENRON NPO, The; CHINA DAILY. The 11th Japan-China Public Opinion Poll: Analysis Report on the Comparative Data. Tokyo, 2015.

GRIES, Peter H. Chinese Nationalism: Challenging the State?. Current History, Philadelphia, v. 104, issue 683, Sept. 2005, p. 251-256.

HE, Yinan. History, Chinese Nationalism and the Emerging Sino-Japanese Conflict. Journal of Contemporary China, Oxford, v.16, issue 50, February 2007, p. 1-24.

HOLLIHAN, T. (Ed.). The Dispute Over the Diaoyu/Senkaku Islands: How Media Narratives Shape Public Opinion and Challenge the Global Order. Palgrave Macmillan US, 2014.

HUANG, Yanzhong. China, Japan, and the 21 Demands. The Diplomat Magazine. January 24, 2015. Disponível em: < http://thediplomat.com/2015/01/china-japan-and-the21-demands / > . Acessado em: 03/12/2015.

JAPAN. Joint Communique of the Government of Japan and the Government of the People's Republic of China, Ministry of Foreign Affairs of Japan (MOFA), 1972. < http://www.mofa.go.jp/region/asia-paci/china/joint72.html > Acessado em: 05/02/2016. 
JAPAN. JETRO survey: Analysis of Japan-China Trade in 2012 and outlook for 2013, Japanese External Trade Organization (JETRO) 2013. Disponível em: < http://www. jetro.go.jp/en/news/releases/20130219452-news > . Acesso em: 17/05/2014.

JAPAN TOURISM. Statistic of visitors to Japan from overseas, Historical Statistics, 2013. Disponível em: < http://www.tourism.jp/en/statistics/inbound/ > .

JAPAN TIMES. Visitors to Japan surge to record 19.73 million, spend all-time high $¥ 3.48$ trillion. The Japan Times News, 19 jan. 2016. Disponível em: < http://www. japantimes.co.jp/news/2016/01/19/national/japan-sets-new-inbound-tourism-record2015-comes-just-short-20-million-target/\#.V-Pbx4grLIU > . Acessado em: 01/06/2016.

KAWASHIMA, Shin . The Origins of the Senkaku/Diaoyu Islands Issue: The period before normalization of diplomatic relations between Japan and China in 1972. Asia-Pacific Review, Vol. 20, issue 2, 2013, p. 122-145.

KENNEDY. Paul M. The rise and fall of the great powers: economic change and military conflict from 1500 to 2000. New York, Random House, 1987.

KISSINGER, Henry. Sobre a China. Rio de Janeiro: Objetiva, 2011.

LA TIMES. Thousands in Chinese provinces stage anti-Japan protest. Los Angeles Times, 18 out. 2010. Disponível em: < http://articles.latimes.com/2010/oct/18/world/lafg-china-japan-protests-20101018 > . Acessado em: 06/05/2016.

PAN, Zhongqi. Sino-Japanese Dispute over the Diaoyu/Senkaku Islands: The Pending Controversy from the Chinese Perspective. Journal of Chinese Political Science, Vol. 12, Issue 1, April 2007, p. 71-92.

POMAR, Wladimir. A Revolução Chinesa. São Paulo: Editora Unesp, 2004.

PUMIN, Yin. The Defeat That Changed China’s History. Beijing Review, Beijing, Vol. 57, 34, Aug. 2014, p. 14-19.

REIS FILHO, Daniel Aarão. A Construção do Socialismo na China. São Paulo: Brasiliense, 1982.

REUTERS. Japan buys disputed islands. China sends patrol ships, Reuters New Agency, 11 set. 2012. Disponível em: < http://www.reuters.com/article/us-japan-chinaidUSBRE88A0GY20120911 > . Acessado em: 06/05/2016.

ROSE, Caroline. 'Patriotism is not taboo': nationalism in China and Japan and implications for Sino-Japanese relations. Japan Forum, Oxford, v.12, issue 2, March 2000, p. 169-181. ROSE, Caroline. Interpreting History in Sino-Japanese Relations: a case study in political decision-making. London and New York: Routledge, 2005.

RUMMEL, R.J. China's Bloody Century: Genocide and Mass Murder Since 1900. New Brunswick: Transaction, 1991

SARAIVA. José Flávio Sombra (org). História das relações internacionais contemporâneas: da sociedade interacional do Século XIX a era da globalização. São Paulo, Editora Saraiva, 2008. 
SIMOES, A.J.G; HIDALGO, C.A. The Economic Complexity Observatory: An Analytical Tool for Understanding the Dynamics of Economic Development. Workshops at the Twenty-Fifth AAAI Conference on Artificial Intelligence, 2011. Disponível em: < http://atlas.media.mit.edu/en/ > . Acessado em: 21/10/2016.

SNEIDER, D. Textbooks and Patriotic Education: Wartime Memory Formation in China and Japan. Asia-Pacific Review, Vol. 20, No. 1, 2013, p.35-54.

SOUZA, H.P. A relação diplomática sino-japonesa no contexto das celebrações dos 70 anos do fim da Segunda Guerra Mundial na Ásia. In: IV SIMPORI - Simpósio de Pós-Graduação em Relações Internacionais do Programa "San Tiago Dantas” (UNESP, UNICAMP e PUC/SP), 2015, São Paulo. Anais eletrônicos. Disponível em: < http://www.santiagodantassp.locaweb.com.br/novo/images/simposio/artigos2015/ PAULINO_A\%20relacao.pdf > . Acesso em: 28/03/2016.

SUZUKI, Shogo. Civilization and empire: China and Japan's encounter with European international society. New York: Routledge, 2009.

TOKYO TIMES. China's Boycott Hurts Japanese Car Makers: “This Is Politics, Not Business”, The Tokyo Times, 2012. Disponível em: < http://www.tokyotimes.com/ 2012/chinas-boycott-hurts-japanese-car-makers-this-is-politics-not-business / > . Acessado em: 09/05/2016.

WASHINGTON POST. Boat collision sparks anger, breakdown in China-Japan talks. Washington Post, 20 set. 2010. Disponível em: < http://www.washingtonpost. com/wp-dyn/content/article/2010/09/20/AR2010092000130.html > . Acessado em: 06/05/2016.

XINHUA. Wisdom Needed in the Expression of Patriotism. News Agency Xinhua, 16 set. 2012. Disponível em: < http://news.xinhuanet.com/english/indepth/2012-09/16/ c_131853756.htm > . Acessado em: 07/05/2016.

YUAN, Jing-Dong. Chinese Nationalism and Sino-Japanese Relations. Pacific Focus, Vol. XXIII, No. 2, August 2008, p. 212-231.

ZHANG, Qiang; WEATHERLEY, Robert. Owning up to the past: the KMT's role in the war against Japan and the impact on CCP legitimacy. The Pacific Review, Vol. 26, No. 3, 2013, p. 221-242. 


\title{
Mudança Institucional em Regimes de Direitos Humanos: o Sistema Interamericano e os Estados "em cima do muro"1
}

\author{
Institutional change in Human Rights Regimes: \\ the Inter-American System And States 'on the fence'
}

DOI: $10.21530 /$ ci.v12n2.2017

Isabela Gerbelli Garbin Ramanzini²

\section{Resumo}

O objetivo do artigo consiste em analisar o desenvolvimento institucional do Sistema Interamericano de Direitos Humanos (SIDH) sob o prisma da relação entre a Comissão Interamericana de Direitos Humanos (CIDH) e os Estados não jurisdicionados. A seleção desse grupo de Estados - que se manteve "em cima do muro" ao longo do processo de transformação do sistema regional em um sistema protetivo - representa um ponto de partida pouco explorado. Como esses Estados encontram-se comprometidos em menor grau com as obrigações regionais de direitos humanos, é comum receberem a pecha de obstáculos à universalização do SIDH. As raras referências aos Estados não jurisdicionados nos estudos sobre o SIDH se restringem a qualificá-los como impedimentos à expansão e ao adensamento institucional do sistema regional. Os achados da pesquisa permitem rivalizar com essa ideia, sugerindo que, embora comprometidos em menor grau, a presença e a participação dos Estados não jurisdicionados no SIDH são parcelas explicativas não apenas do design institucional e funcionamento peculiar do SIDH, mas também da própria continuidade do sistema regional de direitos humanos, por representarem a construção de um fator de estabilidade institucional dentro de um panorama persistente de questionamentos da própria ideia de proteção interamericana dos direitos humanos na região.

Palavras-chave: instituições internacionais; regimes internacionais; direitos humanos; sistema interamericano de direitos humanos

1 Esse artigo resulta de projeto de pesquisa financiado pelo CNPq

2 Fellow no Carr Center for Human Rights Policy, Harvard Kennedy School. E-mail: isabela_garbin@hks.harvard.edu Artigo submetido em 06/02/2017 e aprovado em 17/04/2017. 


\begin{abstract}
The aim of this article is to analyze the institutional development of the Inter-American Human Rights System (IAHRS) under the prism of the relationship between the Inter-American Commission on Human Rights (IACHR) and the non-jurisdictional states. The selection of this group of states - which remained 'on the fence' throughout the process of transforming the regional system into a protective system - represents a little explored starting point. As these States are less committed to regional human rights, they are often referred as obstacles to IAHRS's universalization. The rare references to the non-jurisdictional states in the IAHRS's studies are restricted to qualifying them as impediments to the expansion and to the institutional strengthening of the regional system. The findings of this research allow us to rival this idea, suggesting that, although less committed, the presence and the participation of the non-jurisdictional states in the IAHRS are explanatory parcels not only of the institutional design and functioning of the IAHRS, but also of the continuity of the regional human rights system because they represent the construction of a factor of institutional stability within a persistent panorama of questions of the very idea of inter-american protection of human rights in the region.
\end{abstract}

Keywords: International institutions; international regimes; human rights; inter-american human rights system

\title{
Introdução
}

O Sistema Interamericano de Direitos Humanos (SIDH) conta, atualmente, com 68 anos de existência normativa e 57 anos de funcionamento institucional. Não obstante a duração relativamente extensa desse arranjo regional, o SIDH está longe de se afirmar consensual; pelo contrário, seu histórico institucional vê-se marcado por questionamentos, desde a origem e cada vez de forma mais estridente, por parte dos governos e dos movimentos transnacionais. Num contexto prevalecente de incertezas quanto à política regional no campo dos direitos humanos, uma das indagações mais comuns, dado o binômio resistência (institucional)/hesitação (estatal) no SIDH, refere-se às mudanças e continuidades ao longo de sua trajetória institucional: em quais aspectos seria possível apontar mudanças e continuidades no SIDH? As mudanças institucionais promovidas no SIDH foram substantivas ou apenas graduais? Quais elementos tornaram possíveis mudanças e continuidades institucionais no SIDH? 
Diversas perspectivas lidam com a análise do desenvolvimento institucional do SIDH. Alguns estudos (ALVES, 1997; TRINDADE, 2002) dedicam-se ao exame, geralmente legalista, da produção de normas no SIDH, notadamente, dos tratados interamericanos de direitos humanos. Como resultado, traçam um percurso de sucessões normativas ao longo da existência do sistema regional ${ }^{3}$. Outros trabalhos voltam-se à evolução jurisprudencial (PASCUALUCCI, 2003; PIOVESAN, 20011 RAMOS, 2001), destacando tanto o gradual incremento de matérias substantivas (direitos civis e políticos, direitos econômicos e sociais, proteção às minorias: mulheres, crianças, indígenas e LGBTI), como ganhos em termos procedimentais (excepcionalidade ao esgotamento dos recursos domésticos, controle de convencionalidade, por exemplo) nos órgãos interamericanos. Há trabalhos que lidam com o progresso na participação de atores não estatais no SIDH, avaliando tanto as estratégias desses atores (CAVALLARO; BREWER, 2008a, 2008b), quanto a receptividade do sistema às suas demandas por participação (JIMÉNEZ et al., 2015), de modo que a evolução do SIDH se demonstra a partir dos ganhos na transparência institucional e na participação dos atores não estatais nos mais diversos procedimentos institucionais (opiniões consultivas, processos de reformas institucionais, amicus curiae, entre outros). Alguns trabalhos analisam o desenvolvimento do SIDH a partir do acúmulo de trabalho nos órgãos interamericanos e da capacidade institucional em lidar com os casos da região (BASCH et al., 2010). Também figuram narrativas de experiências profissionais no SIDH (FARER, 1997; BUERGHENTHAL, 2005; MEDINA, 1990), que mesclam percepções pessoais de ex-burocratas às análises sobre as instituições interamericanas. Por fim, há pesquisas que se dedicam à evolução institucional dos órgãos interamericanos, primando pela avaliação dos ganhos de autonomia e competência dos órgãos interamericanos (THEDE; BRISSON, 2011; GOLDMAN, 2009), perspectiva na qual esse artigo se enquadra. Contudo, diferentemente de outros trabalhos, não pretendemos oferecer uma análise estática, a partir da qual se ateste, dentre um regulamento interamericano e outro, a mera adição de competências institucionais, ou a simples descrição de incrementos orçamentários e de infraestrutura institucional. Preocupa-nos, sobretudo, os elementos políticos que orientam as mudanças e continuidades no SIDH.

3 Por exemplo: Carta da OEA e Declaração Americana de Direitos e Deveres do Homem (ambas de 1948), Convenção Americana de Direitos Humanos (1969), Protocolo de San Salvador (1988), Convenções Interamericanas da década de 1990, e assim por diante. 
Há de se destacar, todavia, que os múltiplos processos de transformação institucional no SIDH envolvem uma intensa variabilidade de contextos (local, nacional, regional, global) e de interações estratégicas entre atores de natureza diversa. Essa complexidade causal impõe desafios teóricos e empíricos às tentativas de explorar o tema, frequentemente, também porque os processos de mudança, não raro, são carregados de efeitos não intencionais, de múltiplas causas, de diversos mecanismos causais, quase sempre produzidos por causação conjunta (REZENDE, 2013). Este trabalho propõe enfrentar a questão da mudança e continuidade institucional no SIDH por meio do estudo da relação entre a Comissão Interamericana de Direitos Humanos (CIDH) e os Estados não jurisdicionados. A seleção, em especial, desse grupo de Estados - que se manteve "em cima do muro" ao longo do processo de transformação do sistema regional em um sistema protetivo - representa um ponto de partida pouco explorado.

Como esses Estados encontram-se formalmente comprometidos em menor grau com as obrigações regionais de direitos humanos, é comum receberem, por parte da literatura e do ativismo transnacional, a pecha exclusiva de obstáculos à universalização do SIDH. Portanto, as raras referências aos Estados não jurisdicionados nos estudos sobre o SIDH se restringem a qualificá-los como impedimentos à expansão e ao adensamento institucional do sistema regional. Os achados desta pesquisa permitem rivalizar com essa ideia, sugerindo que, embora "menos" comprometidos, a presença e a participação dos Estados não jurisdicionados no SIDH são parcelas explicativas não apenas do design institucional e funcionamento peculiar do SIDH, mas também da própria continuidade do sistema regional de direitos humanos, ao representarem a construção de um fator de estabilidade institucional dentro de um panorama regional persistente de questionamentos da própria ideia de proteção interamericana dos direitos humanos na região.

$\mathrm{O}$ artigo encontra-se estruturado da seguinte forma. Na primeira seção, apresentamos uma leitura sobre o SIDH enquanto espaço de disputas políticas. Esse ponto contribui para a reflexão sobre a influência dos elementos de poder (não apenas estatal) na explicação das mudanças e continuidades no SIDH. A seção seguinte identifica dois momentos críticos na trajetória institucional da $\mathrm{CIDH}$, como medida comparativa para analisar as trajetórias de mudança e continuidade institucional no órgão interamericano. A última seção examina a relação entre a CIDH e os Estados não jurisdicionados, de acordo com os momentos críticos estabelecidos na seção anterior. Dados - admissibilidade, 
mérito, medidas cautelares, observações in loco, nacionalidade dos comissionados, proporção regional entre comissionados e juízes, entre outros - permitem qualificar a participação dos Estados não jurisdicionados no SIDH entre os períodos, conformando, portanto, indicativos para avaliar quando e como a posição política "em cima do muro" desse grupo de Estados contribui para as mudanças e continuidades no SIDH.

\section{SIDH: espaço de disputas políticas}

Assim como outros sistemas internacionais de direitos humanos, o SIDH, por lidar com questões de alta carga valorativa e com a busca pela responsabilização de Estados por violação ao direito internacional, costuma ser associado, inicialmente, à imagem de uma estrutura neutra, operada por um corpo burocrático, voltada para a promoção de ideais universalmente aceitas. Nessa lógica, a instituição internacional operaria, praticamente, de forma automática e quase que inercial. Outra forma, menos asséptica, de enxergar o SIDH, e por consequência os próprios direitos humanos, seria assumi-los como luta pela afirmação de determinados valores e identidades e enquanto espaço-ação permeado e definido em razão dos conflitos de poder entre atores de natureza diversa. O SIDH representaria, portanto, o resultado dos compromissos políticos, suportados por coalizões de poder. A partir desse raciocínio, as mudanças e continuidades - perspectivas fundamentalmente conectadas - dependeriam de ações coletivas e/ou da coordenação entre os atores para se concretizarem, uma vez que as reformas institucionais corresponderiam a propostas de mudança na distribuição de poder entre agentes, algo geralmente sensível (MAHONEY; THELEN, 2010).

Nessa lógica, a OEA e o SIDH situam-se como o compromisso resultante das disputas político-ideológicas contrastantes a respeito dos moldes e limites da cooperação regional, em particular, no campo dos direitos humanos. O estabelecimento de relações pan-americanas (sob a liderança dos Estados Unidos), ao final do século XIX, representou uma transição decisiva do conceito de bolivarianismo (que favorecia arranjos em torno de uma comunidade política latino-americana) para uma ideia de cooperação interamericana, isto é, do Norte direcionada ao Sul (DYKMANN, 2004). O enquadramento das relações interamericanas no formato de relações dos Estados Unidos para a América 
Latina produziu, ao menos, dois efeitos duradouros no SIDH: (i) uma profunda desconfiança em relação às intenções dos Estados Unidos no arranjo institucional (a qual, inúmeras vezes, ao longo da história do SIDH, é retomada como argumento estratégico pelos governos acusados por violações de direitos humanos) e (ii) o paradoxo da coexistência, normativa e prática, dos princípios da não intervenção e da proteção aos direitos humanos (embate principiológico constantemente desafiado pela CIDH e Corte IDH).

Há de se ter em mente, portanto, que a OEA e o SIDH, desde suas origens e cada vez mais acentuadamente, representam espaços marcados por conflitos de poder entre os diversos atores neles envolvidos, de modo que a configuração de forças regionais, o comportamento estratégico de determinados Estados (mais resistentes ou cooperativos) e dos próprios órgãos interamericanos (não apenas tomados monoliticamente, mas também em razão das individualidades dos comissionados, juízes e demais burocratas) são variáveis explicativas importantes para entender as mudanças e continuidades no SIDH.

Enquanto espaço marcado pelo conflito de poder, as análises sobre a trajetória institucional do SIDH geralmente privilegiaram a influência dos fatores estruturais (choques externos advindos da Guerra Fria, crises econômicas e financeiras na América Latina), das dinâmicas regionais (guerras civis, conflitos políticos, golpes militares, novos movimentos de concertação regional) e os Estados relativamente mais poderosos na região (notadamente os Estados Unidos, Canadá, Brasil, México, Chile e Argentina) para explicar as mudanças e continuidades do SIDH. Por certo, os estudos com foco na presença hegemônica dos Estados Unidos (DONNELLY, 1986, 2003; FORSYTHE, 1991; FARER, 1988; SHOULTZ, 1981), na ausência significativa do Canadá (STEVENSON, 1994; FRANÇA, 2013), na importância estratégica do envolvimento de potências menores como Brasil (AMORIM, 2009) e na excepcionalidade dos desdobramentos de experiências políticas traumáticas, como os regimes ditatoriais do Chile e Argentina (SIKKINK; WALLING, 2010; LUTZ; SIKKINK, 2000; ENGSTROM, 2013), assumem relevância especial nesse tipo de análise. O que pretendemos demonstrar, nesse artigo, é que o foco em Estados menos poderosos (ainda que muitas vezes implicitamente alinhados aos interesses de Estados mais poderosos) pode contribuir para um entendimento mais amplo e matizado do SIDH. Não argumentamos que os Estados não jurisdicionados, no caso desse artigo, tenham precedência explicativa sobre as demais variáveis, mas também não desmerecemos por completo a seu envolvimento no SIDH, tampouco 
os resultados institucionais possibilitados pela sua presença e participação em momentos críticos desse sistema regional ${ }^{4}$.

Os aqui denominados Estados "em cima do muro" se diferenciam dos demais Estados engajados no SIDH em razão de sua objeção circunstancial 5 à jurisdição da Corte IDH. Compõem esse grupo ${ }^{6}$ : Antígua e Barbuda, Bahamas, Belize, Canadá, Cuba, Dominica, Estados Unidos, Guiana, Granada, Jamaica, São Cristóvão e Nevis, Santa Lucia e São Vicente e Granadinas. Há de se reconhecer que esse universo congrega Estados com mais disparidades do que semelhanças, diferenciando-se substantivamente em relação ao poderio econômico, nível de desenvolvimento, tamanho da população e território, tradições históricas, trajetórias políticas, posição geográfica (insular ou continental), entre outras medidas de comparação. Todavia, a combinação dos princípios da soberania e da igualdade formal dos Estados no plano internacional permite delimitar tal grupo em função das suas preferências normativas dentro do SIDH, ainda que haja variações substantivas no padrão de atuação particular de cada Estado nesse sistema regional.

Conformando pouco mais do que um terço (37\%) dos Estados membros do SIDH, os Estados não jurisdicionados não costumam ser considerados significativos para o entendimento do desenvolvimento institucional no SIDH, com exceção, obviamente, dos EUA? ${ }^{7}$. Como se encontram comprometidos em menor grau com os acordos regionais de direitos humanos, a presença e participação desse grupo são, geralmente, compreendidas nos termos do impasse que representam para transformação do SIDH em um sistema de alcance universal ${ }^{8}$. De forma contraintuitiva, argumenta-se que os Estados não jurisdicionados podem ser

4 Conforme resposta proferida a comentário recebido por Comissionado da Comissão Interamericana de Direitos Humanos, em versão anterior do artigo.

5 Esse elemento indica que tais Estados podem mudar, a qualquer momento, sua preferência no SIDH, bastando, para isso, a aceitação integral da CADH.

6 Uma ressalva se faz necessária nesse ponto. A menção ao termo "grupo" não faz referência a uma atuação necessariamente coletiva desses Estados no SIDH, mesmo porque não há indícios formais de que esses Estados ajam coletivamente por meio dos instrumentos/mecanismos interamericanos. Portanto, o uso da expressão "grupo", neste trabalho, refere-se exclusivamente ao agrupamento de Estados em função de preferências iguais quanto à participação formal no SIDH.

7 Os Estados Unidos assumem papel central no SIDH, mesmo formalmente comprometido em menor grau. Alguns elementos fáticos sustentam essa afirmação: sede da OEA e da CIDH em Washington, D.C., financiamento de $2 / 3$ das atividades do sistema regional, presença ininterrupta de um comissionado indicado pelos EUA na CIDH e a participação de juízes norte-americanos na Corte IDH (tribunal ao qual não se submete).

8 A questão da universalidade do SIDH diz respeito à aplicação de um único sistema de regras (padrão de funcionamento) para todos os Estados membros da OEA. Fundamenta-se, mas não se confunde, com a universalidade dos direitos humanos, característica particular das normas de direitos humanos que se refere à aplicação a todos os seres humanos, em qualquer época e em todas as culturas das normas de direitos humanos. 
elementos chave para a compreensão das mudanças e continuidades institucionais do SIDH, principalmente no que se refere à trajetória excepcional de permanência institucional da CIDH em um ambiente politicamente hostil. A análise da presença e participação dos Estados não jurisdicionados em cada um dos momentos críticos do SIDH, descritos nas seções seguintes, fornece subsídios para pensar quando e como esses Estados influenciaram mudanças e continuidades na CIDH, trazendo elementos à uma reflexão mais ampla e matizada sobre o desenvolvimento institucional do SIDH.

\section{Comissão Interamericana de Direitos Humanos: momentos críticos}

A CIDH foi o primeiro órgão a ser criado no âmbito do SIDH, em 1959, e, desde então, tem se mostrado resistente aos mais diversos desafios de continuidade institucional: é questionada por manter o SIDH atado a um design institucional supostamente ultrapassado e ineficiente (se comparado a outros sistemas regionais, como o Sistema Europeu de Direitos Humanos, por exemplo); é contestada pelo viés político impresso em suas ações; e é restringida em suas atuações pelas frequentes restrições orçamentárias impostas pelos governos e pela própria OEA. Mesmo diante de conjunturas, na prática, permanentemente desfavoráveis à sua continuidade institucional, é interessante notar que a CIDH não só se manteve como órgão interamericano, como ampliou consideravelmente seu status institucional na OEA e seus poderes ao longo do tempo. Ou seja, é preciso reconhecer que a CIDH continuou existindo no SIDH e, ao mesmo tempo, enfrentou mudanças graduais que a fortaleceram enquanto instituição, ainda que, em muitos momentos, o cenário esperado fosse o oposto. Nesta seção, pretendemos entender os elementos objetivos de mudança e continuidade na CIDH por meio da comparação analítica entre dois momentos críticos da história institucional do órgão. Definimos como momentos críticos da trajetória institucional da CIDH aqueles processos de mudança que envolveram diretamente a possibilidade de extinção do órgão interamericano por vias formais, isto é, por meio de alterações das normas constitutivas dos órgãos interamericanos ${ }^{9}$.

9 Por certo, é possível sinalizar outros momentos críticos da trajetória institucional do SIDH como, por exemplo, a repercussão da crise financeira da OEA e da crise da dívida na América Latina durante a década de 1980, que quase levaram a organização internacional ao colapso financeiro; a atual proclamada "crise financeira sem precedentes” do SIDH (2016), com demissões em massa dos funcionários do sistema regional e cancelamento de sessões e observações in loco. Todavia, essas crises se diferenciam dos momentos críticos indicados neste 
Considera-se que o primeiro momento crítico a colocar desafios à continuidade institucional da CIDH remete à transição do SIDH para um sistema protetivo, processo que se deu entre os anos de 1969 a 1979, com a adoção da Convenção Americana de Direitos Humanos (CADH) e a efetiva implementação da Corte IDH. Apesar de o SIDH ter sido fundado em bases normativas amplas que permitiram, tempos depois, o surgimento de um tribunal regional, no início do funcionamento do SIDH, eram baixas as expectativas institucionais e os interesses estatais em torno da existência de uma Corte de direitos humanos na região, fato que se depreende ante o decurso temporal entre a previsão legal (CADH, 1969) e a efetiva criação da Corte IDH (1979). A entrada em vigor da CADH marcou a transição para o design final do SIDH, momento em que seria vital para a continuidade do órgão precedente (CIDH) que as prerrogativas dos órgãos interamericanos (adiante CIDH e Corte IDH), na qualidade de características identitárias, estivessem minimamente definidas.

A CIDH foi concebida, originariamente, como órgão autônomo à OEA. Constituía um grupo de estudos voltado a duas atividades principais: (i) documentar violações de direitos humanos e indicar formas de melhorar as condições de direitos humanos nos Estados (âmbito quasi-judicial) e (ii) servir de instância consultiva da OEA em temas de direitos humanos (âmbito promocional). Um dos capítulos mais interessantes da história institucional do SIDH - e sobre o qual pouco se discorreu - foi justamente a elevação da CIDH a órgão principal da OEA, em 1967, a partir do Protocolo de Buenos Aires. As narrativas a respeito dessa transformação institucional geralmente atribuem tal ascensão ao reconhecimento da OEA em relação aos trabalhos realizados pela CIDH. Isso não deixa de ser verdade: à época, a CIDH já contava com boa reputação e com um importante trabalho junto à questão da crise política na República Dominicana, tendo sido, inclusive, indicada ao Nobel da Paz em 1967 (DYKMANN, 2004). Todavia, pouco se debateu a respeito das implicações políticas e institucionais relativa à ascensão da CIDH.

Enquanto a CIDH mantinha o status de entidade autônoma ${ }^{10}$, suas ações estavam atreladas ao Conselho Permanente da OEA, fórum de menor calibre da organização. Ademais, nessa condição subalterna, qualquer resolução passada perante o conselho seria suficiente para extinguir a CIDH. Nota-se, portanto, uma intenção dupla no movimento de alçar a CIDH a um novo status: ampliar e elevar

artigo por caracterizarem formas indiretas - mas não apolíticas - de extinguir ou deixar sem efeito os órgãos interamericanos. Agradeço a Oscar Parra, pela reflexão sobre esse ponto.

10 A concepção da CIDH como entidade autônoma serviria aos propósitos de manter a neutralidade política e autonomia geral dos trabalhos desempenhados pela instituição. 
o fórum decisivo sobre a CIDH e restringir a possibilidade de transformações substantivas no órgão, ambas no intuito de conferir maior solidez institucional à continuidade da CIDH. A principal razão apontada para essa reforma estrutural estaria na insatisfação, notadamente norte-americana, com a ineficiência da OEA em lidar com os problemas econômicos e sociais do hemisfério. Os Estados Unidos enxergavam a OEA como uma conexão onerosa, pouco efetiva, mas necessária com a América Latina; enquanto que a CIDH, a seus olhos, parecia-lhe um instrumento muito mais útil e efetivo (DYKMANN, 2004). Para a CIDH, a proposta também se mostrava altamente interessante, de modo que o status de órgão principal teria o potencial de conferir-lhe, ainda que limitadamente à época, maior autonomia e poder institucional. Quando a CIDH é elevada a órgão principal, passa a submeter-se à Assembleia Geral da OEA, fórum superior e mais "democrático", onde os Estados Unidos teriam supostamente mais influência"1. Nessa nova circunstância, qualquer proposta de modificação (ou extinção) da CIDH prescindiria de emenda à Carta da OEA, um processo, portanto, muito mais dificultoso. Essa jogada combinada de interesses norte-americanos e da própria $\mathrm{CIDH}$ pavimentou o caminho para assegurar a continuidade institucional da CIDH em um terreno normativo e institucional mais firme.

Ainda que com maior solidez normativo-institucional, a previsão de uma corte regional configura o primeiro momento crítico do SIDH, principalmente por colocar em xeque a exclusividade da CIDH em assuntos de direitos humanos na região. Ademais, por estar inicialmente prevista como pacto facultativo, pairava no ar um importante dilema de interpretação das regras do SIDH: para alguns, a $\mathrm{CADH}$, ao entrar em vigor, condicionaria as atividades de ambos os órgãos (CIDH e Corte IDH) à ratificação desse novo documento. Isto é, para que a CIDH continuasse existindo, haveria a necessidade de novo chancelamento estatal de seu mandato (FARER, 1997). Essa nova rodada de aceitação da CIDH poderia se mostrar bastante perigosa para a continuidade do órgão interamericano, principalmente porque, à época, a CIDH já havia começado a dar sinais de sua potencialidade em "incomodar” alguns governos da região.

Em resposta, a CIDH começou a delinear novas versões de seus estatuto e regulamento, condizentes com uma interpretação própria e autointeressada dos dispositivos da $\mathrm{CADH}$, segundo a qual entendeu que a única modificação

11 De acordo com Álvaro Tirado Mejía, ministro das Relações Exteriores da Colômbia: “A reforma do Protocolo de Buenos Aires foi o produto do desejo da América Latina de obter assistência econômica e cooperação dos Estados Unidos” (apud DYKMANN, 2004, p. 63). 
promovida pela entrada em vigor da Convenção Americana foi a adição de uma nova competência à CIDH, específica para dos Estados dela ratificadores (FARER, 1997). Na visão da CIDH, a CADH investiu-lhe um papel duplo: reteve seu status de órgão da OEA, com poderes de promover e proteger os direitos humanos nos Estados partes da CADH e, em adição, tornou-se órgão membro da CADH, com poderes sobre os Estados partes da CADH. Nessa competência adicional, a CIDH passou a atuar em conjunto com a Corte IDH no sistema interamericano de petições. A manutenção das competências anteriores à CADH não só foi um trunfo para garantir exercício sobre todos os Estados membros da OEA, como também para reter certas capacidades conferidas pelo mandato original, como a discricionariedade em iniciar relatórios gerais e conduzir observações in loco sem a permissão dos governos investigados. Como resultado desse processo, observa-se uma renovação formal das funções da CIDH, em que seus poderes também foram ampliados. Ao fim desse primeiro momento crítico, a CIDH passou a cumular outras atividades relevantes, como redigir relatórios anuais e estabelecer um incipiente sistema de recebimento de petições individuais.

Em que pesem os saldos positivos para a CIDH, uma das principais decorrências desse primeiro momento crítico consiste na estruturação do SIDH em função de um duplo padrão de funcionamento ${ }^{12}$. Nele se agregam elementos de hard e soft law $^{13}$ para tornar possível a participação de Estados comprometidos em maior e em menor grau com o sistema regional de direitos humanos. Portanto, o design final do SIDH simboliza, nesse momento, o consenso político possível para a continuidade do sistema regional, de modo que a universalidade - ou o padrão único e, no caso, mais rígido - é rebaixado de pré-requisito para participação no SIDH a mero objetivo institucional, prioritariamente a cargo da CIDH. A busca, ainda que incipiente, pela realização desse objetivo da universalização do SIDH é deflagrada pela CIDH apenas quando as relações entre os órgãos interamericanos

12 O SIDH conta com três níveis de aceitação estatal: (i) anuência apenas aos instrumentos normativos elementares do regime (Carta da OEA e Declaração Americana de Direitos e Deveres do Homem); (ii) anuência aos instrumentos normativos elementares em conjunto com a CADH, sem aceitação da jurisdição da Corte IDH; e (iii) anuência aos instrumentos normativos elementares em conjunto com a CADH, com aceitação da jurisdição da Corte IDH. Na prática institucional, esses três níveis de aceitação podem ser traduzidos no duplo padrão de atuação do SIDH: um, em que apenas a CIDH é órgão reconhecido pelos Estados; e outro em que ambos órgãos interamericanos têm reconhecimento estatal.

13 De acordo com Goldstein (2000), ao traçar um acordo internacional, os governos não enfrentam uma escolha binária entre normas rígidas e brandas. A legalização é um processo marcado por nuances, de modo que os Estados moldam os elementos normativos (obrigação, precisão e delegação) de acordo com suas preferências. Logo, o design do regime internacional tem importância para que os consensos sejam ajustáveis e não rompam a essência do acordo ao longo do tempo (HELFER, 2002). 
se tornam mais amistosas, o que ocorre a partir de 1981, quando a CIDH envia acidentalmente - o primeiro caso ao tribunal regional. Após uma série de reuniões conjuntas para a coordenação dos trabalhos no sistema interamericano de petições individuais, na segunda metade dos anos de 1990, a CIDH passa a incluir - de forma não sistemática e quase ocasional - em seus Relatórios Anuais uma lista de Estados pendentes quanto à adesão à CADH. A ausência de registros, nesses documentos, sobre as atividades relativas à universalização do SIDH, aliás, reforça a ideia de que tal objetivo não mereceu atenção devida da CIDH, pelo menos até o segundo momento crítico.

O segundo momento crítico a colocar desafios à continuidade institucional da $\mathrm{CIDH}$ se refere ao processo de reforma do SIDH, tendente a revisar o funcionamento desse órgão interamericano. Tal processo foi iniciado em junho de 2011, durante a XLI Assembleia Geral da OEA e formalmente finalizado em 201314, com a conclusão das recomendações definidas pelo Grupo de Trabalho Especial de Reflexão sobre o Funcionamento da CIDH para o Fortalecimento do SIDH. Esse momento configura-se crítico ${ }^{15}$ dada a centralidade que o embate entre os Estados jurisdicionados e não jurisdicionados ganha no processo de reforma institucional, ensejando questionamentos sobre o duplo padrão do SIDH, além de propostas radicais, como: mudança de sede física, cerceamento de poderes e, no limite, a dissolução formal da CIDH. A agenda de reformas ${ }^{16}$ caracterizou-se pela assimetria, estando mais focada em abordar as preocupações e interesses de alguns Estados do que de outros atores participantes do sistema (MUÑOZ; ZICCARDI, 2013). Como resultado, as mudanças implementadas por meio desse processo se restringiram ao âmbito do funcionamento do SIDH, tergiversando quanto às outras medidas importantes pendentes de revisão, como, por exemplo, o fomento ao cumprimento estatal e às contribuições financeiras ao regime regional.

14 O desfecho desse processo, apesar de formalmente conclusivo, não colocou fim ao debate sobre as reformas no SIDH. Pelo contrário, por voto dos 35 Estados membros da OEA, deixou-se em aberto a possibilidade da continuidade dos diálogos para reforma.

15 A própria CIDH reconhece a criticalidade do momento ao lançar o seguinte comunicado de imprensa: “CIDH adverte que se atravessa um momento crucial para o Sistema Interamericano de Direitos Humanos”, em que o Presidente da CIDH afirma: “O que está em jogo, que ninguém tenha dúvida, é o patrimônio que os Estados, a sociedade civil e os próprios órgãos interamericanos temos construído para que as atuais e futuras gerações de todo o hemisfério possam todo gozar de seus direitos humanos” [tradução nossa]. Comunicado de Imprensa n. 58/12, 06. Jun. 2012. Disponível em: < http://www.oas.org/es/cidh/prensa/comunicados/2012/058.asp > . Acesso em: 16 set. 2015.

16 Durante o processo, foram abordados oito temas: nomeação do Secretário Executivo da CIDH; desafios de médio e longo prazo da CIDH; medidas cautelares; assuntos de procedimento na tramitação de casos e petições individuais; soluções amistosas; critérios para construção do capítulo 4 do Relatório Anual da CIDH; promoção dos direitos humanos; e fortalecimento financeiro do SIDH. 
Apesar dos resultados pouco favorecedores ao efetivo fortalecimento institucional do SIDH, esse segundo momento crítico reforça a ideia do sistema regional enquanto campo de disputas políticas. Frente aos desafios de continuidade institucional, a CIDH agiu com protagonismo, nesse caso, participando de todas as reuniões do Grupo de Trabalho e registrando seu posicionamento em relação a cada uma das recomendações adotadas pelo Conselho Permanente da OEA. Paralelamente aos encontros dessa ocasião em especial, a CIDH levou a cabo uma série de audiências e fóruns de debate público em diversos Estados membros para envolver interessados e usuários do SIDH no debate sobre a relevância da atuação do órgão interamericano. Um dos movimentos importantes da CIDH, nesse segundo momento crítico, foi o lançamento do Plano Estratégico: 2011-2015, documento que sinaliza uma busca pelo aperfeiçoamento do seu modus operandi, no intuito de: reforçar a importância da atuação histórica da CIDH (inclusive com apelos à reprodução de cartas e depoimentos pessoais de vítimas e seus familiares); mostrar capacidade e, sobretudo, imparcialidade de ação do órgão; e justificar os resultados de suas atividades aos financiadores das atividades. O Plano Estratégico exprime uma versão "executiva” da CIDH, traçando planos, programas de ação e estratégias milimetricamente delineadas dentro de calendários programáticos, fluxos de ação e da metodologia de Administração Baseada em Resultados. Diferentemente da abordagem dos Relatórios Anuais da CIDH, o registro confere evidência ao obstáculo da aceitação universal do SIDH, traçando estratégias para superá-lo ${ }^{17}$. Todavia, quando tomado em conjunto com os demais objetivos, se verifica que a questão da universalização do SIDH encontra-se diluída nas outras atividades do órgão, que não constituem os pilares ${ }^{18}$ de atuação da CIDH. Assim, apesar da CIDH dar visibilidade à questão durante o segundo

17 "No período de 2011 a 2015, a Comissão vai aproveitar todos os seus mecanismos para trabalhar pela aceitação universal dos instrumentos interamericanos de direitos humanos. Durante suas visitas in loco, por exemplo, irá desenvolver e buscar uma agenda de diálogo político com os seguimentos executivo e legislativo dos governos que, por uma questão de rotina, incluem uma revisão do status de ratificação dos instrumentos regionais e convidá-los à ratificação quando a adesão for ausente. Nas suas recomendações, e quando for apropriado, a Comissão irá sublinhar a necessidade de respeitar o quadro interamericano de regras, especialmente quando um vácuo de normas domésticas contribui para as violações de direitos humanos. A Comissão também irá realizar reuniões técnicas e seminários para os representantes dos Estados membros, organizações da sociedade civil e outros grupos de interesse nos países que ainda não ratificaram os instrumentos interamericanos. Essas reuniões e seminários irão fornecer caminhos para o diálogo e uma troca de visões para identificar quais obstáculos persistem de forma a completar a ratificação. O plano da Comissão é conduzir pelo menos uma atividade deste tipo por ano" (CIDH, 2011, tradução nossa).

18 De acordo com o Plano Estratégico, constituem os três pilares de atividade da CIDH: sistema de petição individual, monitoramento da situação de direitos humanos nos países e áreas temáticas. 
momento crítico, o modo como o objetivo da universalização do SIDH pretende ser institucionalmente trabalhado demonstra que esse obstáculo não consiste em prioridade, pelo menos nesse momento. Ao final desse processo de reflexão, a $\mathrm{CIDH}$ embarcou em um programa de reformas regulamentares e de mudança de práticas para atender a maior parte das recomendações adotadas pelo Conselho Permanente ${ }^{19}$, o que sinaliza a possibilidade de mudanças institucionais graduais acontecerem, ao mesmo tempo em que a $\mathrm{CIDH}$ busca meios para garantir sua continuidade institucional.

Assim, por mais que a CIDH tenha persistido enquanto órgão interamericano e seus poderes tenham sido ampliados ao longo do tempo, é importante refletir para além desses resultados. O foco nas interações entre a CIDH e os Estados não jurisdicionados, durante esses momentos críticos, possibilita questionar o problema da permanência da barreira histórica à universalidade do SIDH - e, portanto, da transformação substantiva do SIDH.

\section{A CIDH e os Estados "em cima do muro"}

Delimitados os momentos críticos do SIDH, passamos à análise da relação entre a CIDH e os Estados não jurisdicionados nesses períodos distintos. No primeiro momento crítico (1969-79), a conjuntura regional parece mais favorável ao desenvolvimento institucional do SIDH, nos moldes hemisféricos. A hegemonia norte-americana se faz claramente presente na OEA e no $\mathrm{SIDH}^{20}$, havendo pouca ou nenhuma oposição à sua política anticomunista ${ }^{21}$. Os países latino-americanos encontram-se praticamente todos sob regimes ditatoriais fortemente alinhados aos Estados Unidos. E, tanto o Canadá quanto os Estados caribenhos ${ }^{22}$, até então, não demonstram interesse em compor a OEA, estando os últimos voltados ao desenvolvimento de regimes regionalmente mais circunscritos. Uma vez

19 As alterações podem ser consultadas na Resolução 01/2013 da CIDH. (CIDH, 2013).

20 Nesse período, o financiamento da OEA dependia, em grande parte, dos EUA, que contribuíam com 2/3 do orçamento da organização. Entretanto, enquanto orçamento e staff da CIDH continuavam a crescer, o orçamento da OEA encontrava-se em tendência inversa. Tal paradoxo se explica em razão dos pesados investimentos dos Estados Unidos no SIDH, que podem ser interpretados como uma vontade política de fortalecer a CIDH, em particular, principalmente entre os anos de 1970-77, e mais acentuadamente no governo Carter (1977-81).

21 Vide o apoio massivo dos Estados à expulsão do governo cubano da OEA, em 1962.

22 O Caribe constitui uma região do continente americano formada por treze Estados soberanos e dezessete territórios dependentes. Desses Estados soberanos, atualmente, apenas três se submetem à jurisdição da Corte IDH: Barbados, República Dominicana e Haiti. Trinidad e Tobago denunciaram à CADH em 1998. 
deflagrados, os processos caribenhos de independência, em geral, mantiveram os novos Estados soberanos alinhados à Comunidade das $\mathrm{Nações}^{23}$, fato que, na conjuntura de um mundo bipolar, contribuiu para que essas novas democracias aderissem ao lado liberal, o que acabou simbolizado pela adesão desses Estados à Carta da OEA e, portanto, ao SIDH. O gráfico abaixo ilustra essa situação em que, à medida que os Estados caribenhos vão se tornando novas democracias, passam a se comprometer, ao menos no plano normativo internacional, com o regime regional de direitos humanos ${ }^{24}$. Para além dos efeitos substantivos da adesão desses Estados no SIDH, o timing de adesão é particularmente relevante para análise das mudanças e continuidades da CIDH durante esse momento crítico.

\section{Gráfico 1. Independências e adesões dos Estados não jurisdicionados ao SIDH}

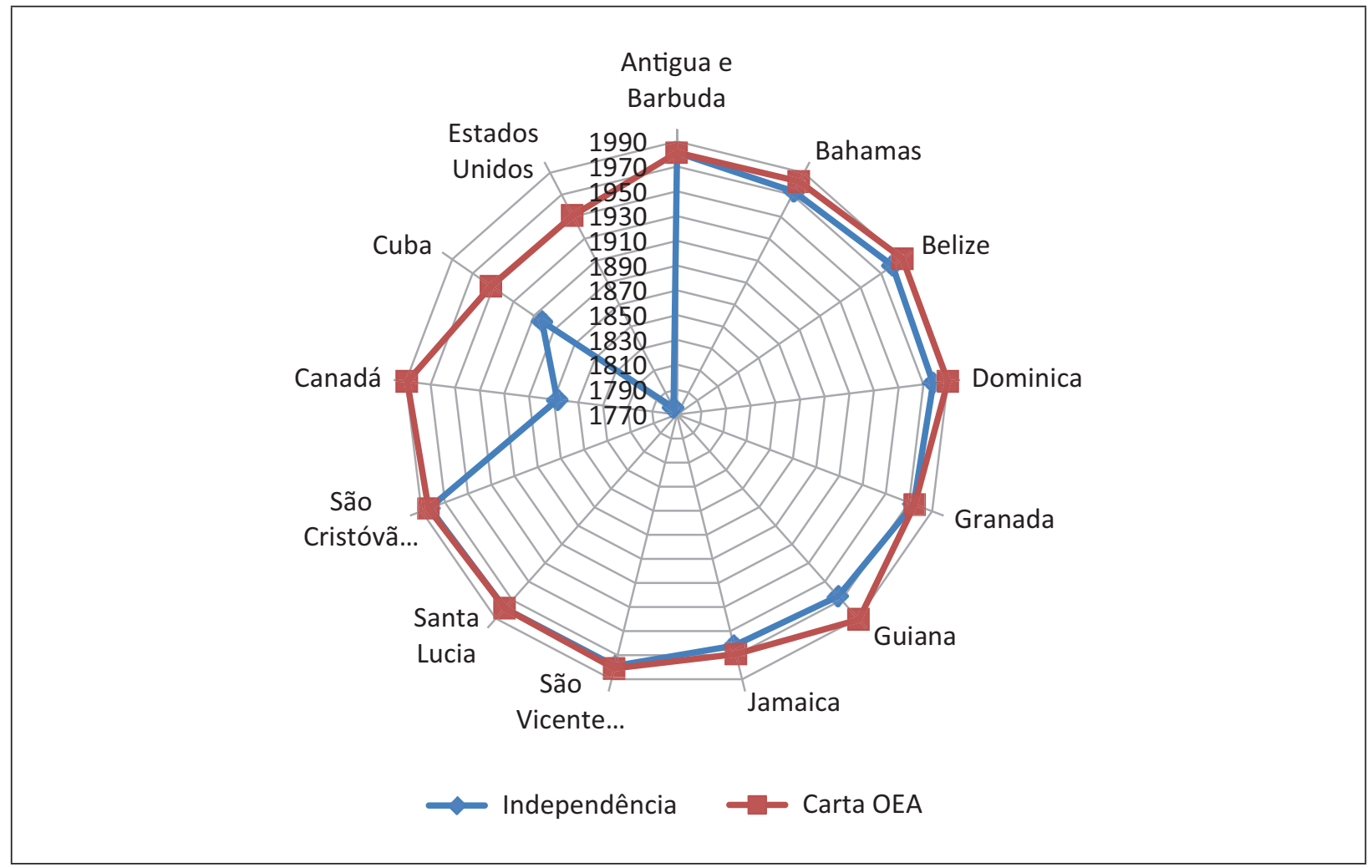

Fonte: Elaboração própria, 2016, baseado em dados de 1770 a 1990.

23 A Comunidade das Nações, anteriormente conhecida como Comunidade Britânica das Nações, é uma organização intergovernamental em que os Estados membros cooperam num quadro de valores e objetivos comuns, definidos pela Declaração de Singapura, que incluem a promoção da democracia, dos direitos humanos, do estado de direito e da paz mundial. A coincidência entre os valores e objetivos da Comunidade das Nações e da OEA contribuiu para a adesão das novas democracias caribenhas ao SIDH. Além disso, o Reino Unido figura como um aliado histórico dos EUA.

24 Nesse sentido, vale um paralelo com o trabalho de Moravcsik (2000), que relaciona o adensamento institucional do Sistema Europeu de Direitos Humanos à democratização e à formação de novos Estados no Leste Europeu. 
A adesão dos Estados caribenhos ao SIDH, mais intensamente durante o primeiro momento crítico, amplia significativamente o número de Estados que passam a compor o regime regional, o que acaba por gerar um elemento de dificuldade quanto à obtenção de consensos sobre normas de direitos humanos mais rígidas e, portanto, de esforços voltados à universalização do SIDH em torno de um padrão único e mais estrito. Assim, a preferência desses Estados pela modalidade não jurisdicionada amplia o rol dos Estados participantes que somente se submetem às normas mais brandas, sedimentando essa posição dentro do SIDH. A conjunção desses dois fatores (ampliação do número de Estados no SIDH e preferência pela posição não jurisdicionada) assume relevância para o entendimento dos rumos do SIDH, porque permite explorar situações em que mudanças institucionais graduais são adotadas como concessões políticas a fim de evitar possíveis rupturas institucionais mais drásticas, como colapso institucional, por exemplo (HELFER, 2002). Esses elementos demonstram que os Estados não jurisdicionados, mesmo se mantendo “em cima do muro", podem figurar um dos elementos explicativos para a continuidade da CIDH durante o primeiro momento crítico, independentemente de outros fatores endógenos geralmente considerados, como, por exemplo, o mérito dos trabalhos e a legitimidade das ações do órgão interamericano. É possível concluir, portanto, que, durante o primeiro momento crítico, a adesão das novas democracias caribenhas à Carta da OEA representa uma contribuição significativa à continuidade da $\mathrm{CIDH}$, particularmente, no momento em que havia perspectivas que tal órgão fosse suplantado pela instituição de um novo órgão interamericano ou de um novo consenso político formalmente mais rígido: a Corte IDH.

Uma participação mais considerável dos Estados não jurisdicionados no SIDH se inicia em meados dos anos de 1990, momento em que a conjuntura internacional e regional torna-se mais favorável, de modo geral, às normas de direitos humanos. A adesão do Canadá ao SIDH em 1989, após longo processo de observação e negociações na OEA, reforça a preferência e a posição política dos não jurisdicionados no SIDH, dando novo fôlego às atividades da $\mathrm{CIDH}$, agora com atribuições compartilhadas com a Corte IDH em pleno funcionamento. Uma das maneiras possíveis de avaliar a relação entre a CIDH e tal grupo de Estados se refere às observações in loco, atividade bastante frequente nesse período. Cerca de $14 \%$ dessa atividade da CIDH se destinou aos Estados não jurisdicionados, de modo que as visitas ocorreram em: Estados Unidos (9 visitas), Bahamas (1 visita), Canadá (1 visita) e Jamaica (2 visitas), embora a grande maioria tenha ocorrido 
na década de 1990. Outro ponto de análise relevante refere-se à abertura política à participação de comissionados de nacionalidades caribenhas na CIDH. De 1970 a 1980, os membros das CIDH advinham principalmente dos grandes países da OEA, como Estados Unidos ${ }^{25}$, Brasil, México e Venezuela, nacionalidades quase sempre representadas no órgão interamericano. Contudo, à medida que mais Estados aderiam ao SIDH, principalmente, a partir dos anos de 1980, a CIDH passou a contar com mais representantes de Estados "menores", estabelecendo-se uma "cota regional não oficial" para assegurar a participação de membros comissionados da América Central e do Caribe (DYKMANN, 2004, p. 79). Considerando que o papel dos indivíduos/comissionados assume um papel fundamental sobre os níveis de compromisso, orientação e iniciativa da CIDH (INTER-AMERICAN HUMAN RIGHTS NETWORK, 2015), o estabelecimento de regras implícitas, que asseguram duas das sete vagas na CIDH para os Estados não jurisdicionados, pode trazer implicações diretas para o manejo das mudanças e continuidades do SIDH.

No segundo momento crítico (2011-2014), a conjuntura hemisférica já se mostra menos promissora ao desenvolvimento institucional do SIDH, conforme exposto na seção anterior. A análise da participação dos Estados não jurisdicionados no SIDH e de suas posições políticas durante o processo de reflexão e reforma da CIDH são elucidativas. Nota-se, nesse segundo momento crítico, um maior envolvimento dos Estados não jurisdicionados no sistema interamericano de petições. Observa-se que, a partir dos anos 2000, esse sistema de petições passa a ser ativado em função de casos individuais relativos aos Estados não jurisdicionados. As decisões (admissibilidade, mérito e medidas cautelares) se avolumam nesse período, observando-se uma maior diversidade de casos e de Estados não jurisdicionados abrangidos. O gráfico abaixo compara a participação dos Estados não jurisdicionados no sistema de petições entre as décadas de 1990, 2000 e 2010. Ainda que essa participação seja limitada, se considerarmos a totalidade dos Estados membros do SIDH, a tendência que se delineia é de crescimento. As projeções ${ }^{26}$ para a década de 2010-2020 revelam que, cada vez mais, os Estados não

25 Os EUA sempre mantiveram comissionados em todas as composições da CIDH: Sandifer (1960-1972), Woodward (1972-1976), Farer (1976-1983), MacColm (1984-1988), Stevenson (1988-1990), Reisman (1990-1995), Goldman (1996-2003), Carozza (2006-2009), Shelton (2010-2013) e Cavallaro (2013-2015).

26 As projeções, nesse ponto, se baseiam meramente no fato de que há, ainda, metade de uma década a ser computada, no período 2010-2019. Trata-se de uma suposição ideal. Projeções mais qualitativas (SALAZAR; CERQUEIRA, 2015) indicam, ao contrário, a diminuição dos números no sistema individual de petições, em especial das medidas cautelares, tendo em vista uma provável atuação de perfil mais baixo por parte da CIDH nos próximos anos. 
jurisdicionados passam a ser abarcados pelo sistema interamericano de petições, em especial, no que se refere às medidas cautelares.

\section{Gráfico 2. Participação dos Estados não jurisdicionados no sistema interamericano de petições}

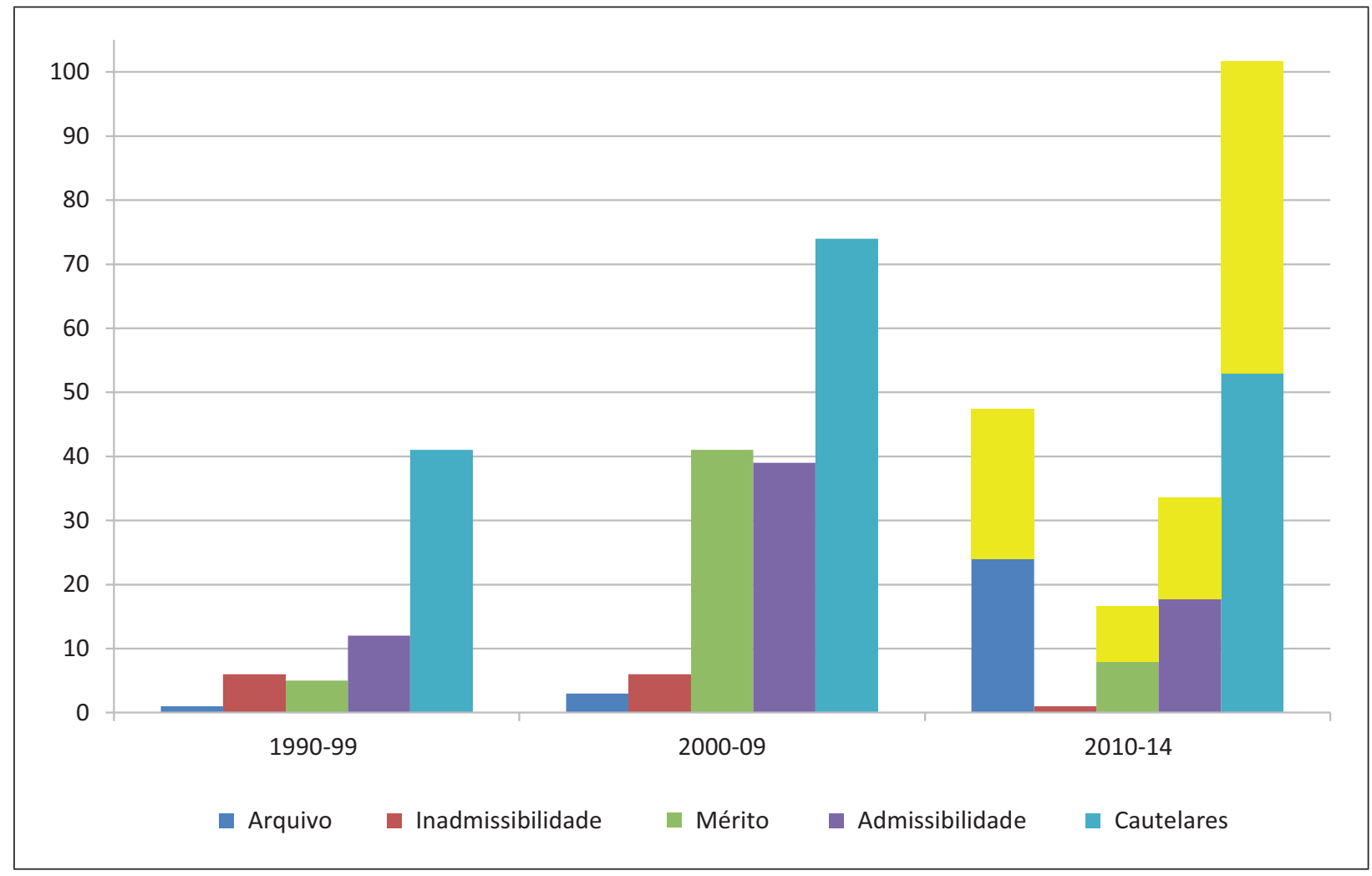

Fonte: elaboração própria com base em dados disponíveis nos Relatórios Anuais da CIDH, 1990 a 2014.

A particularidade sobre as medidas cautelares mostra-se bastante estratégica, pois, dentre as demais medidas adotadas pela $\mathrm{CIDH}$, as cautelares constituem providências mais "brandas": ao mesmo tempo em que sinalizam uma tentativa da CIDH constranger os Estados não jurisdicionados, essas medidas, por natureza jurídica, não consistem em pré-julgamento sobre as violações de direitos humanos. Esse movimento é especialmente importante para legitimar, nesse segundo momento crítico, a necessidade da continuidade do duplo padrão de funcionamento do SIDH, como meio de ressaltar a importância e necessidade da manutenção da ação da CIDH sobre os Estados não jurisdicionados. Tal prática mostra-se útil tanto para a própria defesa institucional da CIDH no processo de reflexão e reforma ${ }^{27}$,

27 No comunicado de imprensa n. 58/21, o Presidente da CIDH afirma: "Uma parte significativa dos trabalhos da Comissão se relacionou a países que não ratificaram a Convenção [...]: de todos os informes de mérito publicados na última década, 44 casos são de países que ratificaram a Convenção, e 25 de países que ainda não o fizeram. Em 2011, por exemplo, três dos cinco informes de mérito publicados são de países que não ratificaram 
como para construção dos discursos de apoio dos Estados não jurisdicionados à continuidade institucional da CIDH. As intervenções feitas pelas delegações dos EUA e Canadá28 nas Assembleias Gerais da OEA, no período de 2010 a 2012, algo incomum nos anos anteriores, são expressões de apoio político e financeiro à manutenção do status quo na $\mathrm{CIDH}$. Representando os Estados caribenhos, as intervenções de Jamaica e Dominica também apoiam a continuidade institucional da CIDH e sinalizam a necessidade de maior inclusão dos Estados caribenhos nas discussões ${ }^{29}$. No que diz respeito à participação de comissionados, nesse segundo momento crítico, são nomeados seis comissionados advindos dos Estados não jurisdicionados (1 de Antígua e Barbuda; 2 da Jamaica, 2 dos Estados Unidos, 1 de Santa Lucia). Outros dois acontecimentos inéditos no SIDH acontecem durante e em sequência a esse período: a CIDH lança um Informe Anual sobre a Jamaica (2012) e recebe doações extraordinárias de Antígua e Barbuda (2016) para manter sua rotina de atividades.

É possível concluir, portanto, que a participação mais qualificada dos Estados não jurisdicionados no segundo momento crítico legitima e fortalece a continuidade institucional da $\mathrm{CIDH}$, ao mesmo tempo que permite a ocorrência de mudanças institucionais graduais ${ }^{30}$, sem que haja, necessariamente, um direcionamento à superação do obstáculo para a universalidade do SIDH. Tanto a forma como os Estados não jurisdicionados participam do SIDH, como o modo com que a CIDH lida com esses Estados parecem demonstrar que os interesses de ambos os atores convergem para que o foco do SIDH se volte mais a outros objetivos (como, por exemplo, o adensamento institucional do SIDH no âmbito de sua atuação sobre os Estados jurisdicionados) do que à universalização. As frequentes menções da CIDH à importância do SIDH para os Estados não jurisdicionados e

a Convenção: um sobre o Canadá que se relaciona ao devido processo em matéria de imigração e dois sobre os Estados Unidos, um relacionado ao devido processo e à pena de morte, e o outro aos deveres do Estado para prevenir e responder à violência doméstica. Com relação às medidas cautelares [...] no ano de 2011 os dois países com mais medidas cautelares outorgadas pela Comissão foram Honduras, com 12, e Estados Unidos, com 11 [...] a Comissão Interamericana foi a primeira organização intergovernamental que solicitou medidas especiais de proteção a favor dos presos pelos Estados Unidos em Guantánamo, e a Comissão Interamericana solicitou reiteradamente o fechamento imediato de tal centro de detenção" [tradução nossa]. Comunicado de Imprensa n. 58/12, 06. jun. 2012. Disponível em: < http://www.oas.org/es/cidh/prensa/comunicados/2012/058.asp > . Acesso em: 16 set. 2015.

28 OEA. Intervenções disponíveis em: < http://www.oas.org/es/cidh/informes/anuales.asp > . Acesso em: 16 set. 2015.

29 Idem.

30 Um exemplo de mudança institucional gradual foi o aperfeiçoamento dos pré-requisitos para lançamento das medidas cautelares, ao fim do processo de reforma 2011-2013. 
o avanço participativo desses Estados no SIDH representam uma comunhão de interesses entre atores de natureza diversa para manter o status quo do SIDH. Nesse ponto, é importante destacar a reconfiguração dos papeis agente-estrutura nos momentos críticos. Em ambos momentos, a CIDH age, por meio de seus poderes (revisão de normas estruturais - estatuto e regulamento; emissão de notas oficiais; participação nos processos de reforma etc.) para alcançar seus objetivos (sobrevivência institucional, no limite). Esse alinhamento de interesses entre CIDH e Estados não jurisdicionados quanto à continuidade institucional da CIDH mostra-se importante para contrabalancear tanto as investidas críticas de alguns Estados (Brasil, Bolívia, Venezuela, Equador) em promover mudanças institucionais substantivas na CIDH, quanto, indiretamente, para mitigar a influência das novas organizações multilaterais na região, tendentes a lidar com questões de direitos humanos (IPPDH-Mercosul, Grupo de Alto Nível de Cooperação e Coordenação em Direitos Humanos-UNASUL, Conferência de Estados partes da CADH).

Por fim, duas leituras mostram-se possíveis a respeito da participação dos Estados não jurisdicionados ao longo da trajetória institucional do SIDH: de um lado, representam, de fato, um impasse à universalização do sistema regional; de outro, podem ser entendidos como um elemento de estabilidade dentro de um sistema regional que funciona por meio de um padrão duplo, e que, por essa razão, é alvo de constantes questionamentos. No caso desse último entendimento, ao contribuírem para a continuidade da $\mathrm{CIDH}$, os Estados não jurisdicionados sustentam a manutenção do SIDH no âmbito hemisférico.

\section{Conclusões}

O enquadramento do SIDH enquanto um espaço de disputas políticas, assim como a escolha dos Estados “em cima do muro" como foco desta pesquisa possibilitam alguns ganhos analíticos relevantes ao exame da mudança e continuidade institucional do regime regional de direitos humanos. O primeiro deles refere-se à desmistificação da ideia de que os Estados "em cima do muro" assumam posições politicamente indefinidas, papéis inerciais e presença obstrutiva no SIDH, simplesmente. O segundo diz respeito à capacidade de explicação do SIDH não somente a partir de um ponto de vista exógeno (choques estruturais, como Guerra Fria, crises financeiras, movimentos de integração regional), tampouco puramente endógeno (relevância do trabalho institucional, legitimidade da ação 
institucional). O reconhecimento da reconfiguração dos papéis agente-estrutura e das coalizões políticas (mais ou menos explícitas) nos momentos críticos do SIDH permitem visualizar como a mudança e a continuidade institucional são resultados de processos de contestação e (re)interpretação das regras institucionais. Destaca-se, nesse estudo, como as variáveis institucionais (financiamento do SIDH, origem dos comissionados, representatividade regional no órgão) - ainda pouco exploradas - assumem importância, quando associadas aos elementos de poder.

No que se refere às conclusões substantivas referentes ao exame da trajetória institucional do SIDH, os resultados da pesquisa questionam a ideia de que esse grupo representa apenas impasse à universalização - e, portanto, à transformação - do SIDH. Ao contrário, as análises sugerem que, apesar de comprometidos em menor grau, a presença e a participação dos Estados não jurisdicionados no SIDH podem representar um elemento de estabilidade do sistema regional, que permitiu não apenas forjar o design institucional e funcionamento peculiar do SIDH, mas também a própria continuidade do sistema regional de direitos humanos, ao representarem a construção de um fator de estabilidade institucional dentro de um panorama regional persistente de questionamentos da própria ideia de proteção interamericana dos direitos humanos na região.

\section{Referências}

ALVES, J. A. L. A arquitetura internacional dos direitos humanos. São Paulo: FTD, 1997. AMORIM, C. O Brasil e os direitos humanos: em busca de uma agenda positiva. Política Externa, v. 18, n. 2, 2009, p. 67-75.

BASCH, Fernando; et al. A eficácia do sistema interamericano de proteção de direitos humanos: uma abordagem quantitativa sobre seu funcionamento e sobre o cumprimento de suas decisões. Sur, v. 7, n. 12, 2010, p. 09-35.

BUERGENTHAL, Thomas. Remembering the early years of the Inter-American Court of Human Rights. In: Center for Human Rights and Justice Working Paper n. 1, 2005, New York, p. 01-17. Disponível em: < http://www.corteidh.or.cr/tablas/31422.pdf > . Acesso em: 06 Fev. 2017.

CAVALLARO, J.; BREWER, S. O papel da litigância para a justiça social no Sistema Interamericano de Direitos Humanos. Sur, v.5, n. 8, 2008a, p. 84-99.

CAVALLARO, James L.: BREWER, Stephanie E. Reevaluating regional human rights litigation in the twenty first century: the case of the Inter-American Court. American Journal of International Law, v. 102, 2008b, p.768-827. 
COMISSÃO INTERAMERICANA DE DIREITOS HUMANOS. Comunicado de Imprensa n. 58/12, 06. Jun. 2012. Disponível em:<http://www.oas.org/es/cidh/prensa/ comunicados/2012/058.asp > . Acesso em: 16 Set. 2015.

COMISSÃO INTERAMERICANA DE DIREITOS HUMANOS. Plano Estratégico: 2011-2015. 2011. Disponível em: < http://www.oas.org/en/iachr/docs/pdf/IACHRStrategic Plan20112015.pdf > . Acesso em: 14 set. 2015.

COMISSÃO INTERAMERICANA DE DIREITOS HUMANOS. Resolução 01/2013. 2013. Disponível em: < http://www.oas.org/es/cidh/decisiones/pdf/Resolucion1-2013esp. pdf $>$. Acesso em: 15 Fev. 2015.

DYKMANN, K. Human rights policy of the Organization of American States in Latin America: philanthropic endeavors or the explotation of an ideal? Princeton: Markus Wiener Publishers, 2004.

DONNELLY, Jack. International human rights: a regime analysis. International Organization, n. 40, v. 3, 1986, p. 599-642.

DONNELLY, Jack. Universal human rights in theory and practice. New York: Cornell University Press, 2003.

ENGSTROM, Par. A special relationship gone normal? Argentina and the Inter-American Human Rights System, 1979-2013. Pensamiento Proprio, v. 38, n. 18, 2013, p. 115-147. FARER, T. J. The grand strategy of the United States in Latin America. New Brunswik, 1988. FARER, T. J. The rise of the Inter-American human rights regime: no longer a unicorn, not yet an ox. Human Rights Quarterly, v. 19, n. 3, 1997, p. 510-546.

FORSYTHE, D. Human rights, the United States and the Organization of the American States. Human Rights Quarterly, v. 13, n.1, 1991, p. 66-98.

FRANÇA, T. C. N. De observador a membro integral: a lenta caminhada multilateral do Canadá em direção à OEA (1972-1990). Interfaces Brasil-Canadá, v. 13, n. 16, 2013, p. 113-130.

GOLDMAN, Robert K. History and action: The Inter-American Human Rights System and the role of the Inter-American Commission on Human Rights. Human Rights Quarterly, v.31, n. 4, 2009, p. 856-887.

GOLDSTEIN, J. et al. Introduction: Legalization and World Politics. International Organization, v. 54, n. 385, 2000, p. 393-96.

HELFER, L. Overlegalizing human rights: International Relations Theory and the Commonwealth Caribbean backlash against human rights regime. Loyola - Los Angeles Law School. Legal Studies Research Paper Series, Paper n. 13, 2002, p. 1832-1911.

INTER-AMERICAN HUMAN RIGHTS NETWORK. The Inter-American Human Rights System: The Law and Politics of Institutional Change. Workshop Summary. Institute of the Americas, University College London: 9-10, October 2015. Disponível em: $<$ http://interamericanhumanrights.org/wp-content/uploads/2015/11/IAHRNLondon-Workshop-Summary-v02.11.151.pdf > . Acesso em: 18 set. 2016. 
JIMÉNEZ, M. et al. Hacia un modelo de transparencia y acceso a la información en el sistema interamericano de derechos humanos. In: MAIA, C. B. et al. Desafíos del sistema interamericano de derechos humanos: nuevos tiempos, viejos retos. Bogotá: Centro de Estudios de Derecho, Justicia y Sociedad, Dejusticia, 2015, p. 108-42.

LUTZ, Ellen L.; SIKKINK, Kathryn. International Human Rights Law and Practice in Latin America. International Organization, v. 54, n. 3, 2000, p. 633-659.

MAHONEY, J.; THELEN, K. Explaining institutional change: ambiguity, agency and power. New York: Cambridge University Press, 2010.

MEDINA, Cecilia. The Inter-American Commission on Human Rights and the Inter-American Court of Human Rights: reflections on a joint venture. Human Rights Quarterly, v. 12, 1990, p. 439-464.

MORAVCSIK, A. The origins of human rights regimes: democratic delegation in postwar Europe. International Organization, v. 54, n. 2, 2000, p. 217-252.

MUÑOZ, A. A.; ZICCARDI, N. S. El processo de reforma al sistema interamericano de derechos humanos (2011-2013): crónica reciente y desafíos futuros. Pensamiento Proprio, v. 38, n. 18, 2013, p. 13-18.

ORGANIZAÇÃO DOS ESTADOS AMERICANOS. Protocolo de Buenos Aires. Disponível em: < http://www.oas.org/dil/esp/tratados_B-31_Protocolo_de_Buenos_Aires.htm > . Acesso em: 06 Fev. 2017.

ORGANIZAÇÃO DOS ESTADOS AMERICANOS. Convenção Americana de Direitos Humanos. 1969. Disponível em: < http://www.cidh.oas.org/basicos/portugues/c. convencao_americana.htm > . Acesso em: 06 Fev. 2017.

ORGANIZAÇÃO DOS ESTADOS AMERICANOS. Declaração Americana de Direitos e Deveres do Homem. 1948. Disponível em: < https://www.cidh.oas.org/Basicos/ Portugues/b.Declaracao_Americana.htm > . Acesso em: 06 Fev. 2017.

ORGANIZAÇÃO DOS ESTADOS AMERICANOS. Protocolo de San Salvador. 1988. Disponível em: < http://www.cidh.oas.org/basicos/portugues/e.Protocolo_de_San_Salvador. htm > . Acesso em: 06 Fev. 2017.

PASQUALUCCI, Jo M. The practice and procedure of Inter-American Court of Human Rights. Cambridge, New York: Cambridge University Press, 2003.

PIOVESAN, F. Proteção dos direitos sociais: desafios do ius commune sul-americano. Revista do TST, v. 77, n.4, 2011, p. 102-39.

RAMOS, André de Carvalho. Direitos humanos em juizo: comentários aos casos contenciosos e consultivos da Corte Interamericana de Direitos Humanos. São Paulo: Max Limonad, 2001.

REZENDE, F. da Cunha. As instituições mudam endogenamente?: limites e possibilidades da mudança institucional endógena na Teoria Institucional Contemporânea. Revista Brasileira de Informação Bibliográfica, n. 76, 2013, p. 33-61. 
SALAZAR, K.; CERQUEIRA, D. Las atribuiciones de la Comissión Interamericana de Derechos Humanos antes, durante y después del processo de fortalecimiento: por un balance entre lo deseable y lo posible. In: MAIA, C. B. et al. Desafíos del sistema interamericano de derechos humanos: nuevos tiempos, viejos retos. Bogotá: Centro de Estudios de Derecho, Justicia y Sociedad, Dejusticia, 2015, p. 144-189.

SHOULTZ, L. Human rights and United States policy toward Latin America. Princeton, 1981. SIKKINK, K.; WALLING, C. O impacto dos processos judiciais de direitos humanos na América Latina. In: REIS, Rossana R. (Org). Políticas de Direitos Humanos. São Paulo: Hucitec, 2010, p. 94-124.

STEVENSON, B. J. R. O ingresso no Sistema Interamericano: o Canadá e a OEA. Contexto Internacional, v. 16, n. 1, 1994, p. 117-144.

THEDE, Nancy; BRISSON, Hughes. International relations and the Inter-american system of human rights promotion and protection: strategic exploitation of windows of opportunity. Quebec Journal of International Law. Edição especial, 2011, p. 07-36.

TRINDADE, A. A. Cançado. A consolidação da capacidade processual dos indivíduos na evolução da proteção internacional dos direitos humanos: quadro atual e perspectivas na passagem do século. In: PINHEIRO, Paulo S.; GUIMARÃES, Samuel P. (orgs.). Direitos humanos no século XXI. Brasília: IPRI, 2002, p. 19-48. 


\title{
Economia Política Internacional da Saúde, autonomia estratégica e segurança nacional
}

\author{
Health International Political Economy, \\ strategic autonomy and national security
}

DOI: $10.21530 /$ ci.v12n2.2017.641

Raphael Padula ${ }^{1}$

\section{Resumo}

Partindo do cenário econômico e político internacional da saúde, caracterizado como um ambiente competitivo e conflituoso, mas também concentrado nas mãos de um grupo de Estados e empresas transnacionais, o artigo analisa a importância das relações interestatais e entre Estado e mercado para a autonomia estratégica de Estados periféricos. Em particular, aborda-se a discussão sobre a ampliação da agenda de segurança dos âmbitos estritamente militar e nacional, propondo o conceito de segurança de saúde como fundamental para a segurança nacional, e suas conexões com as seguranças econômica, política, societal e militar. O argumento central sustenta que, diante do cenário internacional de saúde, Estados periféricos devem buscar a construção de um complexo industrial de saúde próprio e conectado ao industrial-militar, para alcançar sua autonomia estratégica e segurança nacional, diminuindo suas vulnerabilidades externas politicas e econômicas. Tal construção passa pela internalização da produção material e não material e da propriedade de empresas. Utilizando o arcabouço da Economia Política Internacional, combinando o estruturalismo econômico com o realismo da política internacional, o artigo se apoia em revisão bibliográfica de conceitos, dados e experiências históricas de países selecionados e de conflitos de interesses no âmbito internacional.

Palavras-chave: saúde; segurança; autonomia estratégica; indústria de defesa

\begin{abstract}
Based on the international economic and political scenario of health, characterized as a competitive and conflictive environment, but also concentrated in the hands of a group of States and Transnational Corporations, the paper analyzes the importance of interstate

1 Programa de pós-Graduação em Economia Política Internacional do Instituto de Economia da Universidade Federal do Rio de Janeiro, Rio de Janeiro/RJ, Brasil. E-mail: padula.raphael@gmail.com

Artigo submetido em 16/08/2017 e aprovado em 24/08/2017.
\end{abstract}


relations and state-market relations for the strategic autonomy of periphery states. In particular, the discussion is focused on widening of the security agenda from the strictly military and national issues, proposing the concept of health security as fundamental to national security, and its connections with economic, political, societal and military security. Taking the international health scenario, the central argument holds that peripheral states should seek the construction of an industrial health complex of their own and connected to the industrial-military, to achieve their strategic autonomy and national security, reducing their external political and economic vulnerabilities. Such construction involves the internalization of material and non-material production and ownership of enterprises. Using the framework of the International Political Economy, combining economic structuralism with the realism of international politics, the paper is based on a bibliographical revision of concepts, data and historical experiences of selected countries and conflicts of interest in the international scope.

Keywords: Health; security; strategic autonomy; military industry

\section{Introdução}

Partindo do cenário político e econômico internacional da saúde, caracterizado como um ambiente conflituoso e concentrado nas mãos de um grupo de Estados e empresas transnacionais, o artigo analisa a importância das relações interestatais e entre Estado e mercado para a autonomia de Estados periféricos. Em particular, abordase a discussão sobre a ampliação da agenda de segurança dos âmbitos estritamente militar e nacional, discutindo também a noção de ameaças e vulnerabilidades diante desse cenário, propondo o conceito de segurança de saúde e sua conexão com as seguranças econômica, política, societal e militar. O argumento central sustenta que, caso queiram alcançar maior autonomia e segurança diante do ambiente internacional de saúde descrito, Estados periféricos devem buscar a construção de um complexo industrial de saúde próprio, conectado ao industrial-militar, internalizando a produção material e não material e a propriedade de empresas.

Para apoiar a argumentação do artigo, é utilizada a perspectiva da Economia Política Internacional, combinando o estruturalismo econômico com o realismo da política internacional, através da revisão bibliográfica de conceitos, dados e experiências históricas de países selecionados e de conflitos de interesses no âmbito internacional.

Além da introdução e das conclusões, o artigo está dividido em quatro seções. Primeiro, aborda-se o cenário econômico e político, com seus potenciais conflitos e vulnerabilidades para os países periféricos. Na seção seguinte, discute-se a 
importância da indústria de saúde no âmbito nacional, atrelado ao conceito realista de autonomia estratégica, ressaltando também, de forma breve, as interconexões entre indústrias de saúde e de defesa, utilizando como exemplos Estados Unidos (EUA) e China. Na terceira seção, colocam-se a questão da ampliação da agenda de segurança para além do âmbito militar e a discussão entre segurança nacional versus segurança humana e/ou global, envolvendo o tema da segurança de saúde como fundamental para a segurança nacional, que deve ser o foco principal do Estado em um ambiente internacional anárquico e conflituoso.

\section{Saúde: o cenário político e econômico internacional}

A indústria de saúde costuma ter peso importante no produto interno bruto (PIB) dos países. Ainda, é intensiva em tecnologias de ponta (portadoras de futuro) e que se espalham ou conectam a outros setores (de caráter transversal), especialmente a indústria militar, considerando a biotecnologia, a nanotecnologia, o setor nuclear, de materiais, de equipamentos e eletroeletrônicos. Além da dimensão humana, a oferta/demanda dos bens e serviços de saúde possui caráter essencial para o funcionamento e o desenvolvimento da economia, e é considerada estratégica nos Estados fortes e influentes do sistema internacional, ou mesmo nos projetos nacionais de potências emergentes, como China e Índia.

A indústria de saúde global vem registrando continuidade na sua tendência à concentração de propriedade, produção de tecnologias de ponta (patentes) e comércio, nas mãos das grandes empresas farmacêuticas (big pharmas) dos países centrais. O processo de crescente concentração na indústria farmacêutica não é uma tendência recente, como aponta Almeida (2013, p. 275):

O mercado global de fármacos é altamente concentrado e polarizado: a) 10 grandes empresas transnacionais produzem cerca de $50 \%$ do total do mercado e as 20 corporações mais importantes estão localizadas nos EUA, Reino Unido, Europa e Japão, sendo que cada uma delas tem, em média, cerca de 100 afiliados em mais de 40 países (dos quais 19 são países em desenvolvimento); b) EUA, Europa e Japão respondem por cerca de $75 \%$ das vendas e, incluindo-se a América Latina, essa porcentagem sobe para 85\%; c) os países desenvolvidos produzem e exportam medicamentos de alto valor agregado e protegidos por patentes e os demais países em desenvolvimento importam esses medicamentos, sendo que alguns produzem genéricos de baixo valor ou medicamentos alternativos e tradicionais. 
A análise de mercado aponta para uma crescente demanda por produtos biotecnológicos e da nanotecnologia, de maior valor agregado e intensidade tecnológica, o que os tornam um meio para as grandes empresas do setor farmacêutico seguirem sua rota de crescimento e concentração de mercado e superarem a tendência de redução dos retornos sobre o investimento (inclusive em P\&D - pesquisa e desenvolvimento tecnológico). No século XXI, as big pharmas vêm cada vez mais se direcionando para os setores de biotecnologia e nanotecnologia nos seus processos de amplas fusões e aquisições na indústria farmacêutica. Tal processo vem sendo reforçado pela troca de ativos entre empresas que buscam a segmentação e especialização de mercados (VARGAS, 2017). Ainda, no período de 2004 a 2011, é registrada uma tendência de crescimento dos depósitos de patentes na área de biotecnologia em saúde. Ao mesmo tempo, essa apresenta altas barreiras à entrada, por razões de dificuldades tecnológicas, custo de desenvolvimento e produção, o que tende a gerar um mercado concentrado com menor número de empresas de maior porte (VARGAS, 2017).

Segundo Vargas (2017), a partir de estimativas e dados da IMS Health (2013), entre 2012-2017, cerca de dois terços do crescimento das vendas globais do mercado farmacêutico deve decorrer do crescimento dos mercados emergentes. $\mathrm{E}$ "boa parte desse aumento nos gastos globais com medicamentos estará associado com o crescimento do consumo nos mercados emergentes”, com destaque para a China em primeiro lugar, seguida de Brasil, Rússia e Índia. Essas estimativas colocam em evidência a importância do BRICS como mercado.

As big pharmas concentram as atividades e os gastos em P\&D, aproveitando escalas de recursos, dominando os mercados de setores de maior valor agregado e intensidade tecnológica, como biotecnologia e nanotecnologia. No Brasil, por exemplo, as grandes empresas transnacionais do setor de capital estrangeiro concentram seus esforços de inovação em seus países de origem (VARGAS, 2017) ${ }^{2}$. A atividade de inovação tem importância fundamental na sustentabilidade de longo prazo da indústria farmacêutica, principalmente diante do cenário de

2 Para Almeida (2013, p. 277), "Não existem evidências de reversão desse padrão de concentração da indústria de fármacos ou de sua atuação agressiva, mesmo nos casos de adoção dos direitos de propriedade (TRIPS, TRIPS-plus e Declaração de Doha) (ex. Tailândia). Como os direitos de propriedade intelectual são harmonizados globalmente, tampouco se comprova a promessa de maior investimento direto nos países que acordaram o fortalecimento desses direitos. A escalada dos preços dos medicamentos é objeto de grande preocupação para a maioria dos países, sobretudo aqueles em desenvolvimento e os mais pobres. Algumas exceções - como Índia, Brasil e Tailândia - têm maior capacidade de produção, entretanto, no caso da produção de genéricos na Índia, com preços bem mais baixos, que a posiciona como um dos maiores fornecedores dos países de renda média e baixa. As compras e fusões de indústrias pelas transnacionais já começou a acontecer”. 
esgotamento e expiração de patentes na indústria farmoquímica, associada a um aumento da demanda social e mudanças no perfil epidemiológico. Vale ressaltar que as atividades produtivas e de P\&D das big pharmas têm como objetivo gerar lucros, critério que não atende às chamadas “doenças negligenciadas”, específicas de países em desenvolvimento.

No entanto, tal processo de crescente concentração não pode ser encarado como um fenômeno de mercado, ou puramente impulsionado pela força econômica de grandes empresas. Desde os anos de 1970, o sistema interestatal vem se tornando cada vez mais competitivo e conflituoso. Tendência reforçada no século XXI com a expansão de potências emergentes - China e Índia -, a retomada de uma política expansiva da Rússia, a crescente oscilação política e divisão da Europa, os surgimentos de Estados, coalizões de Estados e grupos políticos contestadores na periferia, e a política em busca da manutenção ou prolongamento da atual ordem hierárquica por parte dos EUA. Nesse sentido, deve-se acelerar a busca por acesso a mercados e recursos estratégicos na periferia do sistema, incluindo cada vez mais a América do Sul e a África (FIORI, 2013). O sistema internacional pós Guerra Fria seguiu sendo caracterizado pela sua estrutura assimétrica de distribuição de poder e riqueza e pela sua natureza anárquica e competitiva interestatal. Ampliaram-se as divergências de renda, riqueza e tecnologia (revelada no registro de patentes de tecnologias de ponta), ao mesmo tempo em que a atividade industrial se concentrou cada vez mais nos países desenvolvidos e poderosos militarmente (com exceção dos países do sudeste asiático) ${ }^{3}$, e os conflitos militares não foram eliminados, só se aceleraram (FIORI; PADULA; VATER, 2013). No mesmo sentido, aumentou a dependência econômica e tecnológica dos países subdesenvolvidos, inclusive na área de saúde ${ }^{4}$, e sua diferença de poder militar e político foi se acentuando. Por conta de suas dimensões, mercados e recursos estratégicos, a América do Sul e a África estão inevitavelmente inseridas na crescente competição das grandes potências.

As potências tradicionais e algumas das emergentes vêm promovendo uma série de acordos bilaterais e regionais, principalmente diante das complicações persistentes na conclusão da Rodada de Doha da OMC (Organização Mundial do Comércio). Os acordos regionais que EUA e União Europeia (UE) vêm negociando

3 Ao longo dos anos de 2000, os relatórios anuais da UNCTAD (Trade and Development Report) abordam esse processo impulsionado pela liberalização dos anos de 1980 e 1990.

4 Ver Volumes 1 e 5 da série A saúde no Brasil em 2030..., organizados por C. Gadelha, J. N. Carvalho, T. R. Pereira, editados pela Fiocruz; Ipea; Ministério da Saúde; SAE - Rio de Janeiro. 
ou firmando buscam aprofundar a regulação em temas já presentes na agenda da OMC, os chamados “OMC-plus” - regras de origem, salvaguardas, serviços e propriedade intelectual - e “OMC-extra” - que são novos temas, como concorrência, compras governamentais, meio ambiente e legislação trabalhista, sem discutir subsídios agrícolas. Enquanto China e Índia vêm promovendo uma série de acordos, no entanto, mais focados na liberalização de mercados, acesso a investimentos e na regulação de subsídios. Assim, embora os países subdesenvolvidos tenham se articulado e alcançado a Declaração de Doha para flexibilizar o TRIPS em favor da área de saúde (ALMEIDA, 2013, p. 276)5 ${ }^{5}$ atualmente, as grandes potências, e especialmente os EUA, vêm buscando acordos bilaterais e regionais que buscam estabelecer regras de propriedade intelectual que vão além do TRIPS (conhecidos como “TRIPS Plus") 6 .

Embora o governo Donald Trump venha promovendo algum grau de reversão, que pode ser temporário, os EUA vêm buscando promover acordos de livre-comércio e arranjos de integração aberta no hemisfério ocidental, na Ásia-Pacífico e no Atlântico Norte? . Nas negociações bilaterais, os EUA exercem um poder de barganha

5 Para Almeida (2013, p. 276): “As implicações do Acordo TRIPS para a saúde pública levou os países em desenvolvimento a proporem, e obterem, a adoção da Declaração de Doha, cujas flexibilidades seriam "necessárias à proteção da saúde pública e nutrição”. Isso ocorreu em abril de 2001, quando o governo norueguês sediou uma reunião que incluiu OMS, UNICEF, Banco Mundial, as grandes indústrias farmacêuticas transnacionais e poucas ONGs, para discutir estratégias que possibilitassem melhoria de acesso dos países pobres a drogas e medicamentos de alto custo. Embora a questão de licença compulsória tenha sido considerada, a reunião terminou por aprovar a proposta de 'preços diferenciais' para países de baixa renda, que continuou a favorecer a indústria farmacêutica. Essa proposta foi endossada sete meses depois, na reunião do Conselho de Ministros da OMC, em Doha em 2001, que adotou a Declaração de Doha (o Doha Statement on TRIPS and Public Health), que reafirmou as flexibilidades previstas no TRIPS para apoiar problemas relacionados à saúde e reiterou os direitos dos países de usarem a licença compulsória para a produção e melhora do acesso aos medicamentos genéricos. O princípio subjacente a essa Declaração é que a saúde pública teria prioridade sobre as regras do comércio internacional e, para tal, afirma a legitimidade da licença compulsória assim como certas flexibilidades no Acordo TRIPS para países que não dispõem de desenvolvimento industrial. A reunião de Doha comissionou um processo de elaboração de regulamentos para essas situações”.

6 "A resposta dos EUA e da Europa foi desconsiderar esse acordo negociado na OMC e começar a negociar acordos livres bilaterais e regionais, o que envolve a aceitação de concessões dos países em desenvolvimento, parceiros desses acordos (...) A questão da propriedade intelectual nesses acordos bilaterais e regionais (chamados 'TRIPS plus') proporciona muito mais proteção para as grandes indústrias farmacêuticas do que os TRIPS originais da OMC (...) Desde 2001, qualquer acordo comercial norte-americano inclui aspectos relativos à proteção do direito de propriedade intelectual dos fármacos por período mais longo que os 20 anos previstos no TRIPS. Esse padrão ‘TRIP-plus' erodiu de forma importante as flexibilidades previstas na Declaração de Doha” (ALMEIDA, 2013).

7 O EUA liderou a criação do NAFTA (Área de Livre Comércio da América do Norte) em 1994. Em relação aos países da América do Sul, após o fracasso do seu projeto da ALCA - entravado sob a liderança de Argentina, Brasil e Venezuela na Cúpula de Mar Del Plata de 2005 -, o EUA vêm estabelecendo Tratados de Livre Comércio (TLC) bilaterais, especialmente com as pequenas economias exportadoras de commodities da costa do Pacífico - Chile e Peru - e com seu aliado estratégico na região - a Colômbia. 
mais direto e assimétrico, alcançando maiores vantagens que em negociações multilaterais - como acesso a compras governamentais, investimentos e serviços financeiros, direitos de propriedade intelectual e mesmo acordos militares. Com abrangência geográfica mais ampla, os EUA vinham liderando as negociações da Trans-Pacific Parnership (TPP) e da Transatlantic Trade and Investiment Partnership (TTIP) $^{8}$ que, somadas, buscariam isolar o BRICS 9 .

No âmbito do TPP, foi negociado um amplo e ambicioso acordo de liberalização, através de amplos pacotes envolvendo: livre circulação de bens, serviços (especialmente financeiros) e investimentos; acesso recíproco a compras governamentais; regras comuns de origem; eliminação de obstáculos ao comércio e ao investimento dentro das fronteiras dos países (com apoio técnico e financeiro dos países do TPP); respeito aos direitos de propriedade; acordos relativos à propriedade intelectual (inclusive em farmacêuticos), visando reforçar e desenvolver o Acordo da OMC sobre os TRIPS.

Entre as várias posições contrárias à TPP, os congressistas estadunidenses ${ }^{10}$ vinham mostrando preocupação de que essa se concentrasse em proteger a propriedade intelectual em detrimento dos esforços para proporcionar o acesso a medicamentos a preços acessíveis nos países em desenvolvimento. Outro temor também era de que a TPP não seria suficientemente flexível para

8 As negociações do Acordo de Parceria Transatlântica de Comércio e Investimento (TTIP, sigla em inglês), entre os Estados Unidos e a União Europeia (UE), vêm registrando progressos nas três áreas principais de negociação: (i) acesso a mercados, incluindo como avançar para o intercâmbio de ofertas sobre contratação pública e comércio de serviços; (ii) regulamentação, coerência e compatibilidade regulatória, barreiras técnicas ao comércio e medidas sanitárias e fitossanitárias; (iii) regras sobre desenvolvimento sustentável, padrões trabalhistas e ambientais, comércio de energia e matérias-primas, e facilitação do comércio e procedimentos alfandegários.

9 A TPP se origina em 2005, envolvendo Brunei, Chile, Nova Zelândia e Cingapura, posteriormente aderindo às negociações: Austrália (2008), Canadá (2012), EUA (2008), Japão (2013), Malásia (2010), México (2012), Peru (2010) e Vietnã (2008). A TPP ganhou maior relevância em 2009, quando o presidente Obama anunciou a intenção dos EUA de participar das negociações para concluir um ambicioso acordo na Ásia-Pacífico, reforçando a participação estadunidense nas economias dinâmicas da região.

10 "Letter from 10 Representatives asking for a meeting to discuss IP policies that could "undermine public health and access to medicines.". 3 August 2011. Retrieved 30 January 2012. Disponível em: < http://infojustice.org/ wp-content/uploads/2011/08/Ten-Representatives-on-TPP-08022011.pdf >

"Letter from Senator Sanders to US Trade Representative Ron Kirk". 1 December 2011. Retrieved 30 January 2012. Disponível em: < http://keionline.org/sites/default/files/Sen_Sanders_letter_to_USTR_TPP_ negotiations_12-1-2011.pdf > .

"Letter from Representatives Levin, Waxman, McDermott and Conyers to US Trade Representative Ron Kirk". 19 October 2011. Retrieved 30 January 2012. Disponível em: < http://infojustice.org/wp-content/uploads/2011/09/ Four-Democrat-Reps-10192011.pdf > .

"Letter from Reps. Lewis, Stark, Rangel, Blumenauer, and Doggett asking that the May 10th agreement serve as a "non-negotiable starting point" for access to medicines". 8 September 2011. Retrieved 30 January 2012. Disponível em: < http://infojustice.org/wp-content/uploads/2011/09/Five-MOCs-September-8-2011.pdf > . 
acomodar os programas de reembolso de medicamentos não discriminatório e os diversos sistemas de saúde já existentes dos países membros. Entre diversos exemplos, podemos citar que os opositores da TPP apontaram que as corporações estadunidenses teriam acesso a mercados e minariam esforços para proporcionar o acesso a medicamentos a preços acessíveis no Vietnã, e que estariam esperando para enfraquecer a capacidade da Pharmac ${ }^{11}$ de obter medicamentos genéricos de baixo custo, forçando a Nova Zelândia a pagar por medicamentos de marca. Médicos e organizações como Médicos Sem Fronteiras também manifestaram preocupação. As empresas estadunidenses, principalmente a indústria farmacêutica que possui lobby fortíssimo, têm enorme interesse em resguardar (ou ampliar) seus direitos de propriedade intelectual nos moldes do TRIPS e ter acesso às compras governamentais e mercados dos demais países através de acordos como o TPP, excluindo a China e os demais BRICS.

As negociações de amplos acordos que envolvem Estados com enormes assimetrias almejam assegurar vasto mercado e posições privilegiadas com ganhos extraordinários para as grandes empresas transnacionais estadunidenses, especialmente as relacionadas à área de saúde. Ao mesmo tempo, minam a possibilidade de florescimento de indústrias nos países menos desenvolvidos e o acesso ao mercado e a competitividade de empresas de outros países de fora do acordo, que poderiam promover suas indústrias ou arranjos cooperativos. Por isso, do ponto de vista das grandes potências, e especialmente do EUA, é mais viável negociar e costurar tais acordos vantajosos fora da OMC e das negociações multilaterais da Rodada de Doha, onde podem enfrentar o posicionamento organizado e conjunto dos países menos desenvolvidos.

É ilustrativo mencionar alguns dos casos relacionados à área de saúde que demonstram conflitos e/ou vulnerabilidades, potenciais e reveladas, para países no sistema internacional. Por exemplo, as disputas de propriedade intelectual e compras governamentais, que são objetos de impasses nas negociações comerciais multilaterais, ou o acesso a medicamentos e vacinas em contextos de epidemias (PADULA et al., 2015).

O conflito em torno da liberdade de trânsito de medicamentos genéricos no âmbito dos direitos de patentes é um caso ilustrativo. As autoridades europeias realizaram sistemáticas apreensões de medicamentos genéricos em seus portos,

11 A agência governamental da Nova Zelândia que decide quais os produtos farmacêuticos podem ser financiados por fundo público na Nova Zelândia. 
restringido a circulação desses bens essenciais à saúde humana, cujas patentes das grandes empresas multinacionais não encontram direito de proteção nos países de origem e de destino, mas somente na Europa. Como os medicamentos se encontravam em trânsito e não se destinavam ao mercado europeu, não caberia aplicação de direitos de propriedade intelectual das empresas farmacêuticas titulares de patentes na Europa, e nem é cabível alegar danos a essas - se as mesmas não registraram as patentes nos países de origem e destino, ou se as mesmas expiraram, ou se o comércio se dá baseado em princípios de saúde pública. Além de violar o TRIPS e a Declaração de Doha, tais ações arbitrárias e unilaterais violam o artigo V do GATT que prevê liberdade de trânsito.

Em 2008, no porto de Roterdã, alegando questões de propriedade intelectual, as autoridades holandesas apreenderam uma carga do genérico LOSARTAN, produzido na Índia e destinado ao Brasil. Tal episódio demonstra o grau de acirramento dessa disputa ${ }^{12}$ e como as autoridades europeias colocam a questão da propriedade intelectual acima da saúde pública de outros povos; ou seus interesses políticos e econômicos acima dos interesses socioeconômicos de outros países. Outros registros de carregamentos detidos em portos europeus tinham como destino Nigéria, Vanuatu, Peru, Colômbia, Equador, México e Venezuela. Os carregamentos continham medicamentos essenciais para o tratamento de HIV, doenças coronarianas, esquizofrenia, Alzheimer, colesterol e hipertensão. Obviamente, os atingidos são as populações dos países menos desenvolvidos ou subdesenvolvidos.

A importância dos portos dos países europeus nas rotas comerciais internacionais - em razão de sua posição geográfica e vigor econômico - aufere a esses países posições importantes em rotas comerciais de bens estratégicos, o que, por sua vez, confere-lhes maior poder de veto político à sua circulação. Por outro lado, gera vulnerabilidade aos países dependentes dessas rotas comerciais e de suas

12 "As apreensões de medicamentos em trânsito têm sido objeto de polêmico debate em diversas instâncias internacionais. O confisco, ocorrido em 4 de dezembro de 2008, de $570 \mathrm{~kg}$ de Losartan Potassium, princípio ativo usado para a produção de medicamentos para o tratamento de hipertensão arterial, recebeu particular destaque. O produto, avaliado em $€ 55$ mil, havia sido negociado entre a empresa indiana Dr. Reddy`s e a brasileira EMS e estava a caminho do Brasil, mas não alcançou seu destino final. Apesar de o fármaco não ser protegido por patente nem na Índia nem no Brasil, a carga foi confiscada na Holanda, país onde a multinacional MerckSharp\&Dohme (MSD) detém sua patente em conjunto com a DuPont. A MSD enviou uma carta à Dr. Reddy`s por meio de seus advogados em 24 de dezembro de 2008, informando a empresa da retenção e exigindo a renúncia da carga, sob ameaça de destruição do produto. Segundo nota de esclarecimento da Merck do Brasil, a carga retornou à Índia por solicitação da Dr. Reddy`s, após permanecer retida por 36 dias no porto de Roterdã”. (REIS; FARIA, 2010) 
relações exteriores para o abastecimento desses bens, caso não possuam ou não busquem alternativas.

O caso da influenza A (H1N1) demonstrou que, diante de pandemias, as soluções predominantes não são de caráter global, mas as grandes potências buscam garantir seus interesses nacionais, sua estabilidade interna e segurança nacional. Assim, o caso ilustra a vulnerabilidade que pandemias podem causar a países que não possuem produção autônoma de medicamentos e vacinas. Diante do surto, os países centrais garantiram em primeiro lugar o acesso a medicamentos às suas populações, e o governo brasileiro, por exemplo, encontrou dificuldades de suprir as necessidades internas do país. No caso de fornecimento de vacinas, as empresas buscavam priorizar contratos já estabelecidos e, diante do pedido da OMS de conceder vacina grátis aos países pobres, concederam apenas parcialmente ou negaram (esse é o caso da Novartis).

No bojo do espírito da globalização e do livre mercado, os países desenvolvidos vêm promovendo o papel da OMC na regulação do mercado de medicamentos, de acordo com os interesses de suas grandes empresas, e em detrimento do papel da OMS (ALMEIDA, 2013). Estados fortes atuam de acordo com os interesses das suas empresas e da manutenção de assimetrias estruturais no sistema internacional, promovendo acordos e usando sua influência em organizações internacionais como forma de legitimar seus interesses, construindo regras e regimes internacionais que lhes sejam favoráveis ${ }^{13}$. No âmbito global, a busca por acesso facilitado a mercados na área de saúde coloca em foco os países emergentes, visto que as previsões são de aumento da participação de seus mercados nas vendas globais de medicamentos, devido a uma maior incorporação de contingentes populacionais ao mercado consumidor de produtos de saúde. Assim, esse crescimento tem impacto em mudanças nas estratégias competitivas e de inovação das grandes empresas farmacêuticas globais e de seus Estados. Chase-Dunn, Niemeyer; Allison (2005) aponta a importância da liderança biotecnológica dos EUA na sua estratégia estatal de prolongamento hegemônico, e como o Estado e suas agências lideraram iniciativas para o setor desde a década de 1980. Ainda, Reis, Landim e Pieroni (2011) destacam o processo de catching-up de China, Índia e Israel na rota biotecnológica,

13 Para Krasner (2009, p. 13), "regimes internacionais são definidos como princípios, normas, regras e procedimentos de tomada de decisão, sobre os quais as expectativas dos atores convergem em uma determinada área temática”. Princípios são formados por um conjunto coerente de afirmações teóricas sobre como o mundo funciona. Normas especificam padrões gerais de comportamento. Princípios e normas definem a característica básica de qualquer regime. 
através de estratégias lideradas pelo Estado, através de incentivos regulatórios, financiamento e uma política industrial abrangente. Padula (2015) mostra que, em seus documentos de reuniões e ações, os BRICS vinha articulando em favor de uma reforma da agenda internacional na área de saúde, envolvendo o papel da OMS, flexibilização do TRIPS, universalização e maior acesso a medicamentos a menor custo para os países subdesenvolvidos (e não somente os BRICS), incluindo seu financiamento para comercialização, produção e acesso tecnológico. Assim, revelam-se tensões políticas interestatais e o que Krasner (1985) chamou de conflito estrutural, que abordaremos na próxima seção.

\section{Indústria de saúde e autonomia estratégica}

Gadelha e Costa (2013) apontam que a análise do Complexo EconômicoIndustrial da Saúde (CEIS) se debruça sobre a relação sistêmica estabelecida entre segmentos industriais e o setor de serviços de saúde e, consequentemente, sobre sua construção sistêmica no âmbito de uma economia nacional. A análise do CEIS coaduna-se à utilização do arcabouço teórico conceitual da economia política da saúde, que coloca em relevo as tensões relativas aos interesses sociais diante dos econômicos envolvidos, politizando o debate e evidenciando a necessidade de atuação do Estado na construção de seu arcabouço legal-institucional. Tal perspectiva segue a abordagem estruturalista da economia política "que privilegia os fatores histórico-estruturais característicos da sociedade brasileira”, passando pela sua “inserção internacional, assim como sua relação com uma difusão extremamente assimétrica do progresso técnico e, nos termos atuais, do conhecimento e do aprendizado, dissociados das necessidades locais" (Gadelha; Costa, 2013, p. 109) ${ }^{14}$.

Tal abordagem enfatiza questões fundamentais como a relação entre o complexo industrial de saúde e a universalização do acesso à saúde do ponto de vista econômico e social, e ressalta potenciais conflitos políticos decorrentes dessa lógica, na dimensão política interna - principalmente entre empresas e

14 A análise estruturalista latino-americana originou-se com Raúl Prebisch e aprofundou-se com Celso Furtado, que agregou a dimensão histórico-estrutural à análise da relação centro-periferia, e especificamente dos países periféricos. Para um panorama amplo desta tradição, verOctavio Rodriguez, "O estruturalismo latino-americano", São Paulo: Civilização Brasileira, 2005. Para conferir a visão de Furtado, ver: Celso Furtado, “Teoria e Política do Desenvolvimento", São Paulo, Cia. Editora Nacional, 1967. 
Estado - e na arena internacional - do ponto de vista da atuação das empresas transnacionais ou das relações econômicas (comerciais, financeiras e acerca de direitos de propriedade intelectual) entre Estados. Ampliando essa visão, deve-se introduzir maior enfoque nas relações interestatais, na qual os conflitos não resultam somente de interesses econômicos, mas também de interesses eminentemente político-estratégicos presentes nas relações de poder interestatais em um sistema anárquico onde os Estados buscam cumprir suas funções básicas de prover segurança e desenvolvimento para suas sociedades, na busca pelo acúmulo relativo de poder e riqueza frente a outros Estados. O acúmulo de poder e de riqueza atuam de forma coadunada e sinérgica. Mas um Estado rico e sem poder pode ser encarado como débil e vulnerável frente aos interesses e ações de potências externas.

O cenário internacional político e econômico da saúde apresentado na seção anterior indica que a análise sobre um complexo industrial da saúde nacional deve levar em conta o conceito de autonomia estratégica e encará-lo como objetivo político de um Estado frente ao sistema internacional anárquico. A concepção de autonomia estratégica tem um caráter político e vai além da concepção jurídica internacional de soberania. Partindo das visões de Hélio Jaguaribe e Juan Carlos Puig (apud GRANATO, 2014)15, a autonomia estratégica refere-se ao grau de liberdade política de um Estado para tomar decisões, tanto no âmbito da política interna quanto externa, objetivando a construção de regras favoráveis ao seu desenvolvimento socioeconômico e à sua segurança, frente aos interesses e ações de atores externos no sistema internacional - que muitas vezes se articulam com interesses de grupos políticos internos com interesses específicos. Nesse sentido, a autonomia estratégica remete também à busca pela autossuficiência econômica como um modelo ideal, mesmo que não alcançável, mas no sentido de se tornar menos dependente (ou vulnerável) nas suas relações exteriores no que diz respeito à produção e abastecimento de bens estratégicos - seu comércio, suas tecnologias e seu financiamento.

15 Sobre Jaguaribe, ver JAGUARIBE (1979). “Autonomía periférica y hegemonía céntrica”. Estudios Internacionales, n. 49, pp. 91-130, abr.-jun. 1979. Santiago de Chile. JAGUARIBE (1973). “Dependencia y autonomía en América Latina”. In: JAGUARIBE, H.; FERRER, A.; WIONCZEK, M. S.; SANTOS, T. dos. La dependencia político-económica de América Latina. Buenos Aires: Siglo XXI Editores, 1973, pp. 1-85.

Sobre Puig, conferir: PUIG, Juan Carlos (1986). “Integración y autonomía de América Latina en las postrimerías del siglo XX”. Integración Latinoamericana, Buenos Aires, ano 11, n. 109, pp. 40-62, jan.-fev. 1986. PUIG, Juan Carlos (1980). "Doctrinas internacionales y autonomía latino-americana”. Caracas: Instituto de Altos Estudios de América Latina de la Universidad Simón Bolívar. 
A busca pela autonomia estratégica e sua relação com a industrialização, como política de Estado, estiveram presentes em autores de economia política como Alexander Hamilton (estadunidense) e Friedrich List (alemão). Mais propriamente, esses autores viam o processo de industrialização não só como o motor da diversificação e do progresso econômicos, mas como uma forma de buscar internalizar a produção dos bens estratégicos como meio para alcançar maior independência (liberdade) política no sistema internacional, ou reduzir as vulnerabilidades externas nos campos econômico e político num processo de superação de Estados rivais.

Segundo Gilpin (2001, p. 80-81), a busca pela autonomia nacional envolve a inevitável colisão entre a lógica do mercado e a lógica do Estado ${ }^{16}$. Do ponto de vista aqui defendido, envolve também conflitos de interesses interestatais. Assim, da distribuição de poder assimétrica do sistema interestatal emergem conflitos estruturais, como aponta Krasner (1985), pois, caso queiram alterar sua condição de vulnerabilidade e dependência, os Estados subdesenvolvidos não podem deixar de desafiar (reformar) princípios, normas e regras que são de interesse das potências do hemisfério norte e de suas grandes corporações. Assim, a formação de um complexo industrial de saúde aparece como peça fundamental para um Estado que almeje buscar sua autonomia estratégica. Mas esse não pode fazer tal coisa sem desafiar regras e regimes que são de interesse dos Estados mais poderosos e de suas empresas transnacionais - como revelam as tensões citadas na seção anterior.

Vale destacar também a potencial relação sinérgica entre indústria de defesa e indústria de saúde. O complexo industrial-militar estadunidense possui relações intrínsecas com o setor de saúde, um modelo que vem sendo copiado pelo complexo industrial-militar chinês (MEDEIROS, 2004; MEDEIROS; TREBAT, 2013). O setor de saúde sempre foi encarado como um setor estratégico pelas grandes potências, tanto internamente quanto para sua projeção externa (o que transparece em sua postura de buscar acordos internacionais relativos a comércio, serviços, investimentos, propriedade e compras governamentais), e vem sendo

16 "Um dos temas dominantes no estudo da economia política internacional (EPI) é o persistente conflito entre a crescente interdependência da economia internacional e o desejo de Estados individuais de manter sua independência econômica e autonomia política. Ao mesmo tempo em que os Estados querem os benefícios da liberalização do comércio, investimento estrangeiro e equivalentes, eles também desejam proteger sua autonomia política, valores culturais, e estruturas sociais (...) Enquanto a lógica do mercado é alocar atividades econômicas onde elas forem mais eficientes e lucrativas, a lógica do Estado é capturar e controlar o processo de crescimento econômico e acumulação de capital com o objetivo de aumentar o poder e o bem-estar econômico da nação (...)” (GILPIN, 2001, p. 80-81). 
encarado desta forma pelas potências emergentes. Se observarmos as empresas líderes globais na produção e nas inovações, vamos encontrar predominantemente empresas estadunidenses, europeias e japonesas, e, num processo de catching-up, empresas chinesas, indianas e israelenses. Por questões de espaço, serão apontados aqui brevemente os casos dos EUA e da China.

Ao longo de sua história e principalmente após a Segunda Guerra Mundial, no período da Guerra Fria, os EUA desenvolveram um arranjo institucional complexo e eficiente envolvendo empresas, universidades e agências governamentais, o chamado complexo industrial-acadêmico-militar, que teve nesse período e tem até hoje papel fundamental na sua liderança científica e tecnológica - desde a ciência básica até tecnologias de ponta. São inovações que transbordam do setor militar para o setor civil (MEDEIROS, 2004, p. 9). O DARPA teve importante papel nesse processo. ${ }^{17}$ Diversos projetos e escritórios dentro do DARPA buscam o desenvolvimento e a liderança científica e tecnológica, incluindo vários campos que impactam a indústria de saúde, como química, novos materiais, microeletrônica, ciência da computação, robótica, automação, biotecnologia, nanotecnologia, tecnologia nuclear, neurociências, entre outros. Entre eles, destacamos o Defense Sciences Office (DSO), o Microsystems Technology Office (MTO) e o Biological Technologies Office (BTO) - esse criado em abril de 2014.

Medeiros e Trebat (2013, p.7) destacam que a China seguiu a mesma linha e, no sentido do DARPA, “criou o 'Programa de pesquisa em alta tecnologia 863' em 1986, com foco em automação, biotecnologia, energia, tecnologia da informação (TI), lasers, novos materiais e espaço”.

Para Chase-Dunn, Niemeyer; Allison (2005), a liderança tecnológica em setores estratégicos é um dos elementos centrais para que um Estado consiga alcançar e manter uma posição hegemônica no sistema interestatal, tanto pelo seu impacto vantajoso na produção física quanto no poder militar; ou para que, pelo menos, figure no andar superior da hierarquia econômica e político-militar do sistema.

17 “O Advanced Research Projects Agency (DARPA), subordinado ao DOD [Departamento de Defesa], teve especial liderança na criação de novas tecnologias. Para este esforço, o fator limitante não era a disponibilidade de recursos financeiros. Depois da guerra, os militares obtiveram amplo apoio financeiro e as políticas de compra do DOD criaram uma vigorosa demanda protegida para as principais indústrias fornecedoras de armamentos. O fator limitante era o estoque de conhecimento e a estrutura operacional do sistema de inovações. Deste modo, a tarefa não se circunscrevia à provisão de incentivos para P\&D nas indústrias ou nas universidades, mas na montagem de um extenso e dinâmico sistema de inovação. O desafio era reduzir o período de tempo entre as invenções e inovações acelerando o progresso técnico e dirigindo-o para a produção de "armamentos radicalmente novos”. Este desafio foi assumido pelo DOD” (MEDEIROS, 2004, p. 9). Ver também: Merritt Roe Smith (editor) (1985). Military Enterprise and Technological Change Cambridge. MA: MIT Press. 
Chase-Dunn, Niemeyer; Allison (2005) chamam de "novas indústrias líderes" aquelas que transbordam tecnologias para outros setores, possuem capacidade de gerar "rendas tecnológicas" (monopolísticas) por um período, influenciando inclusive a indústria militar. Assim, o domínio de tecnologias líderes ou estratégicas tem implicações geopolíticas sobre a distribuição de poder econômico e militar, e suas rivalidades. Olhando especificamente para a hipótese de declínio da hegemonia dos EUA, afirmam:

Depois que uma maior competição internacional surgiu, os EUA continuaram a angariar rendas tecnológicas por inventar, produzir e exportar novos produtos, incluindo equipamentos de energia nuclear, tecnologia militar e tecnologia da informação. Agora, muitos acreditam que as vantagens dos EUA no campo da biotecnologia poderão contribuir substancialmente para uma nova rodada de hegemonia econômica dos EUA nas próximas duas décadas. (Chase-Dunn, Niemeyer; Allison, p. 5, tradução livre).

Assim, apontam as indústrias de biotecnologia, de alimentos e medicina, na posição futura dos EUA nos próximos dois séculos, fazendo uma associação entre ciclos de liderança tecnológica e ciclos hegemônicos.

As experiências históricas de grandes potências e das potências emergentes apontam que o Estado tem o papel de liderar o processo de construção da indústria de saúde, com adequadas regulações, mobilização de recursos e arranjos institucionais envolvendo setores estatais, acadêmicos e empresariais. Como mostram os casos dos EUA e China, a percepção estratégica de interconexão entre indústria de defesa e saúde costuma vir das estratégias de formação da indústria de defesa, ao envolver a área de saúde. Como já afirmado, os segmentos que formam o complexo industrial de saúde são constituídos por indústrias portadoras de tecnologias de futuro, com caráter estratégico, que se espalham por outros setores da economia e são fundamentais para o desenvolvimento e a segurança nacional, características similares à da indústria de defesa.

\section{Saúde e Segurança Nacional}

No período pós Guerra Fria, a evolução dos estudos estratégicos, e especificamente da segurança internacional, ampliou a agenda de segurança para além da questão militar, buscando incorporar a noção de "ameaças" que partem de outras áreas e atores, e não somente da agressão militar de um Estado contra 
outro. Barry Buzan (1991) foi um autor seminal e influente nesse sentido, ao apontar que, no século XXI, a agenda de segurança deveria se ampliar para além da segurança militar para temas como seguranças: política, econômica, societária e ambiental - temas de segurança (security issues) que teriam interconexões entre $\mathrm{si}^{18}$. Segundo Buzan (1991), a segurança militar compreende as capacidades ofensiva, defensiva e dissuasória das Forças Armadas; assim como as percepções do Estado sobre as intenções de outros atores e seus poderes, e vice-versa. A segurança política abrange a estabilidade organizacional dos Estados, dos sistemas de governo e das ideologias que os legitimam. A segurança econômica trata do acesso a recursos, financiamento e mercados necessários à sustentação de níveis aceitáveis de bem-estar social e poder estatal. Esses são os temas de segurança abordados em Buzan (1991) que mais interessam neste artigo, e que têm uma interconexão forte com o que podemos chamar de segurança de saúde, compondo a agenda de segurança nacional.

Na perspectiva de um suposto mundo pacífico e livre de disputas interestatais, e/ou caracterizado pela interdependência econômica e pelo livre mercado, o pensamento liberal propõe que a paz e a segurança deveriam ser tratadas de forma cooperativa pelos Estados, como um tema global e transfronteiriço, confiando em organizações internacionais (como a ONU e a OTAN) e na atuação benevolente dos Estados mais ricos e poderosos, tirando a nação do centro do debate $^{19}$. Nessa linha, surge a argumentação de que, num mundo globalizado e com significativo fluxo de pessoas entre países, epidemias deveriam ser tratadas predominantemente de forma coletiva. Ou de que o tema da segurança humana em países subdesenvolvidos deveria ser tratado através de uma perspectiva focada no individuo ou cosmopolita (MCINNES, 2008). Podemos apontar como resultado dessa agenda de negociações de acordos liberalizantes baseados na ideologia da globalização: o GATT e o GATS (respectivamente, sobre comércio de bens e serviços), o TRIPS (relativo a propriedade intelectual), o TRIMS (relativo a investimentos), e mesmo o Tratado de Não Proliferação Nuclear (TNPN).

18 Ressaltamos que não concordamos com todas as especulações e visões de Buzan, especialmente sobre o cenário pós Guerra Fria. No entanto, o autor tem contribuição fundamental para os estudos de segurança ao ampliar a agenda para outros temas e, para os fins desse estudo, não é relevante discorrer sobre divergências em relação ao autor.

19 No campo da Economia Política Internacional, por exemplo, Robert Keohane, em After Hegemony, defende que os EUA utilizariam seu excedente de poder, surgindo como única superpotência no pós Guerra Fria, para construção de regimes, instituições e organizações internacionais, que levariam maior cooperação e estabilidade ao sistema internacional. 
Colin McInnes (2008) aponta que a agenda de segurança de saúde trata de epidemias que, num mundo globalizado com significativo fluxo de pessoas entre países, deveriam ser tratadas predominantemente de forma coletiva ou focada no indivíduo, o que não justificaria sua inclusão no campo da segurança nacional. Simon Dalby (2008) destaca que a abordagem da segurança humana traz uma mudança da centralização no Estado e território para as pessoas. A segurança humana significa a segurança frente a ameaças crônicas como fome, doença e repressão - que pode se relacionar com miséria e falta de acesso a condições mínimas de alimentação e salubridade em países subdesenvolvidos. Caroline Thomas (2008) reforça tal mudança ao afirmar que (i) a questão da segurança se volta para seres humanos individuais e a proteção e cumprimento de seus direitos humanos; (ii) a busca de outros níveis de seguridade - global, regional ou nacional - tem relevância e legitimidade na medida em que apoia a segurança humana; (iii) a segurança humana não pode ser definida ou constrangida dentro de limites territoriais de uma unidade política exclusiva; (iv) a busca de segurança nacional por um Estado não deve comprometer a segurança humana de seus cidadãos ou ainda de pessoas vivendo além de seus limites territoriais.

McInnes (2008) aponta que há três temas principais tratados na agenda de segurança sobre saúde: (1) a propagação de doenças infecciosas (tuberculose, gripe aviária, AIDS, SARS, ebola) para o “Ocidente” (como elemento exógeno); (2) pandemia de AIDS/HIV (que pode ser inserido no anterior); (3) guerra biológica: em função da difusão e uso de armas biológicas por grupos radicais (bioterrorismo). Nesses temas, a saúde estaria diretamente ligada à questão da segurança, através de potenciais efeitos desestabilizadores. Para o autor, as epidemias podem provocar, num espaço curto de tempo, um nível elevado de absenteísmo ou mesmo mortes, prejudicando o funcionamento do Estado e da economia, além de gerar um ônus significativo nos gastos públicos. Há também a possibilidade de revolta política, especialmente caso a população não acredite que está sendo atendida de forma adequada, ou que apenas segmentos mais privilegiados da população estão tendo acesso à assistência médica adequada. McInnes (2008) destaca que relatório da CIA, de 1999, argumenta que, com a globalização e os crescentes movimentos de pessoas e mercadorias, emerge o risco vindo de doenças infecciosas que podem se espalhar globalmente e atingir os cidadãos estadunidenses, podendo afetar o crescimento econômico e a estabilidade internacional e, consequentemente, tornarse um problema de segurança nacional. Ele aponta que, em 2000, o Conselho de Segurança apontou a ameaça da pandemia de AIDS à segurança proveniente de 
três efeitos: (i) coloca em risco o funcionamento e a estabilidade do Estado - nos campos econômico, social e político; (ii) as forças de segurança (militares) e de paz como potenciais difusores, pelo seu deslocamento; (iii) e que a propagação da AIDS é exacerbada em condições de violência. Levando em conta especificamente a hipótese de mobilidade de tropas em conflitos como vetor transmissor de doenças, de forma crítica, McInnes (2008) argumenta que a relação entre epidemia de HIV e segurança não é muito conclusiva, visto que conflitos podem tanto impulsionar quanto restringir o deslocamento de tropas e civis e, portanto, a disseminação de HIV. Além disso, programas de prevenção podem e efetivamente reduzem a propagação do HIV entre as tropas.

Do nosso ponto de vista, o tema das guerras biológicas e sua relação com a segurança de saúde em um país periférico, especialmente os de tradição pacífica, devem considerar se esse almeja obter uma projeção de ator global e influenciar o sistema internacional. Nesse caso, deve estar preparado para possíveis ações hostis originadas a partir de divergências de interesses com outros Estados militarmente fortes e/ou que dominam tecnologias de armas biológicas. Ainda, na abordagem desses temas, se encontra o dilema entre cooperação coletiva e uma abordagem nacional para prevenção ou solução. Por outro lado, no discurso das grandes potências, os países periféricos (especialmente os caracterizados por estados “irresponsáveis” ou “falidos”) podem ser identificados como abrigos (voluntários ou não) de grupos radicais ou como focos de epidemias, justificando práticas de “ajuda” e/ou intervenções.

Considerando o cenário econômico e político internacional e os casos conflitivos apresentados na primeira seção, somando-se os efeitos desestabilizadores políticos e econômicos ao Estado e à sociedade (de âmbito nacional) causados por epidemias (nacionais e/ou globais) apontados por McInnes, revela-se a impossibilidade de que Estados periféricos possam confiar na cooperação global, na visão cosmopolita ou num conceito de segurança humana para o acesso a vacinas e medicamentos fundamentais. Por outro lado, reforçam a ideia de que a indústria de saúde nacional é fundamental para a segurança nacional, desenvolvimento e autonomia estratégica de um Estado periférico, reduzindo suas vulnerabilidades diante influências e decisões de abastecimento concentradas nas mãos de empresas transnacionais ou de seus Estados de origem.

A concepção aqui defendida, apoiada na busca pela autonomia estratégica estatal em um sistema interestatal competitivo e anárquico, encara que a segurança de saúde deve ser tratada a partir de uma perspectiva nacional, como um tema de 
segurança e desenvolvimento nacional. Seguindo a definição de Buzan (1991) para segurança econômica, poderíamos definir a segurança de saúde como o acesso a recursos, financiamento e mercados na área de saúde, necessários à sustentação de níveis aceitáveis de bem-estar social e poder estatal. Pelo seu caráter estratégico, o setor de saúde não pode ser tratado como parte da segurança econômica. Ainda, a segurança de saúde pode ser vista como a capacidade de um Estado (economia nacional) de produzir internamente os bens e serviços de saúde que atendam às necessidades de sua população, de forma a universalizar o acesso tanto em tempos de paz como diante de contenciosos e conflitos político-econômicos interestatais. Depende, assim, do domínio de tecnologias, da capacidade financeira e produtiva, e de mobilização de recursos em tempo hábil. Sobretudo, depende de um projeto nacional e de capacidade e coesão política interna para articular diferentes setores em prol desse objetivo superior, diante de possíveis constrangimentos e ações externas. É importante sublinhar que a segurança sanitária possui interconexões com outros temas de segurança: econômica, política, societal, militar e alimentar.

Diante da necessidade ou da conveniência de importação, ou da não viabilidade da produção interna, seria fundamental para a segurança de saúde, nos termos definidos acima, que o Estado: em períodos de conflitos ou diante de contenciosos políticos, seja capaz (em tempo hábil) de mobilizar recursos para a produção de medicamentos antes importados; não dependa de fontes restritas de importação (seja país(es) ou empresa(s)); diversificar o máximo possível as fontes de importações (em termos de áreas geográficas, de países e empresas, ou coalizões desses, olhando para a propriedade do capital das empresas), assim como diversificar as rotas comerciais de abastecimento, as fontes de financiamento e moedas em denominação de contratos. Sem embargo, a segurança sanitária e a segurança econômica possuem relações estreitas. A abordagem de segurança de saúde aponta a necessidade de olhar para a propriedade do capital das empresas que atuam no país, possibilidades de transferência tecnológica e perfil de empresas que fazem comércio com o país (independente de sua localização territorial). Os processos identificados de concentração global da propriedade das empresas (através de fusões e aquisições) e da inovação tecnológica (patentes), com consequente processo de desnacionalização da indústria nacional, tendem a gerar vulnerabilidades econômicas e políticas, tornando vulneráveis a segurança de saúde e, de forma mais ampla, a segurança nacional. 


\section{Conclusões}

O cenário econômico internacional na área de saúde aponta para uma crescente concentração da propriedade de empresas, produção e geração e propriedade de tecnologias nos países centrais, a partir de suas grandes empresas transnacionais. As indústrias biotecnológica e nanotecnológica seguirão crescendo de importância, a indústria de equipamentos e materiais seguirá sendo fundamental, e as TICs (tecnologias da informação e comunicação) serão crescentemente importantes.

Ao mesmo tempo, no âmbito político internacional, a tendência é de que os Estados poderosos acirrem as disputas por mercados, acessos a investimentos e compras governamentais, direitos de propriedade intelectual, e pela influência na construção de regras e da agenda internacional de saúde, tentando garantir os interesses de suas grandes empresas e tornar Estados periféricos ainda mais dependentes, vulneráveis externamente e instáveis politicamente internamente. Os conflitos em torno de direitos de propriedade intelectual, ou das relações desses com o trânsito internacional de medicamentos e a produção de medicamentos com menores custos, e do acesso a medicamentos e vacinas em períodos de pandemias, mostram um ambiente internacional conflitivo onde os interesses nacionais de Estados e interesses econômicos de empresas tendem a ser priorizados sobre interesses sociais, humanos ou globais.

$\mathrm{Na}$ agenda de saúde internacional, seguirão as ações das grandes potências, que perseguem seus interesses estratégicos e são pressionadas por suas grandes empresas, para a manutenção de regras no sistema internacional que sejam favoráveis à continuidade da expansão e concentração de mercado. Trata-se, portanto, de uma atuação incisiva e contrária a ações que não sejam condizentes ou desafiem as regras e regimes de manutenção do status quo. Tal quadro aponta para a tendência de crescentes conflitos em questões de saúde no âmbito internacional, relativos a comércio de bens e serviços, investimentos e direitos de propriedade intelectual. No âmbito das organizações internacionais - Conselho de Segurança da ONU, OMC, OMS -, as grandes potências seguirão se articulando em torno dos seus interesses e marginalizando políticas contrárias. A tendência então é de aprofundamento do padrão de expansão e concentração da indústria de fármacos (e não de reversão) nas mãos das big pharmas, visto que os mesmos fatores que o consolidaram persistem. 
A falta de acesso a medicamentos gera efeitos desestabilizadores sociais, econômicos, políticos e de segurança no Estado e na sociedade. A construção do complexo industrial da saúde deve ter um papel fundamental na autonomia estratégica e na segurança nacional, principalmente do ponto de vista da segurança econômica e da segurança política, além do potencial de conexão com a indústria de defesa (e consequentemente com a segurança militar).

Por sua importância socioeconômica e tecnológica, o desenvolvimento da indústria de saúde é fundamental como vetor de crescimento, para a estabilidade interna, para a segurança interna e externa do País, para diminuir sua vulnerabilidade econômica e política, e para aumentar o grau de independência nas suas relações exteriores. Além do caráter social, a universalização do acesso trabalha em favor da estabilidade política interna, ao eliminar diferenças internas em relação ao acesso da população a bens e serviços básicos. É importante para a segurança nacional de um Estado também por torná-lo autossuficiente em possíveis períodos de conflitos ou interrupção de fluxos e, assim, menos vulnerável a pressões internacionais e aos interesses (poder de barganha) de potências externas. Ainda, a distribuição geográfica das atividades da indústria de saúde e a universalização do acesso aos seus bens e serviços por todo o território nacional (pelas suas diferentes regiões, inclusive fronteiriças) são importantes do ponto de vista do desenvolvimento socioeconômico do território nacional, do seu aproveitamento em todas as suas potencialidades geográficas e da segurança do território nacional - ao promover o domínio político e a ocupação demográfica, econômica e militar adequada de todo o território e de seus recursos. Assim, considerando sua importância econômica, tecnológica, social, política e militar, o complexo industrial nacional de saúde é estratégico e seu destino não pode ser deixado ao mercado global, à vontade de potências externas, de organizações internacionais e de empresas transnacionais.

Nos países BRICS, há uma forte demanda por produtos e serviços de saúde. O caráter indutor do desenvolvimento das compras governamentais é tão evidente que, recorrentemente, as mesmas aparecem como um dos impasses nas negociações da Rodada de Doha, promovida no âmbito da OMC. A forma como essa demanda crescente será suprida deve estar associada ao padrão de desenvolvimento e inserção internacional que os Estados pretendem. Nesse sentido, é preciso observar dois aspectos: a capacidade nacional de ofertar os produtos e serviços necessários para atender, não apenas à demanda doméstica como também concorrer internacionalmente com a produção das demais potências, podendo inclusive ser um vetor estratégico de inserção geopolítica; e a concorrência internacional das 
transnacionais fomentadas inclusive pelas estratégias geopolíticas de seus países sede. Do contrário, seu crescimento econômico e seus crescentes mercados podem se transformar em maior dependência e vulnerabilidade externa, transferindo recursos públicos para grandes empresas transnacionais sediadas em países centrais. Os países do BRICS têm em comum, além de um crescente mercado, o compromisso estatal com a universalização do acesso à saúde, a reforma do sistema internacional na área de saúde e o acesso a medicamentos em países subdesenvolvidos. As doenças e medicamentos pouco rentáveis são negligenciados pelas grandes empresas farmacêuticas transnacionais, não obstante afetarem grande número de pessoas e serem extremamente importantes para a medicina. Os interesses da saúde e os interesses dos mercados estão em caminhos opostos, assim como os interesses dos Estados centrais e periféricos ou emergentes, especialmente quando esses buscam reformas no sistema internacional, e especificamente no sistema de saúde internacional, de forma articulada através de alianças.

\section{Referências}

ALMEIDA, Célia . Saúde, Política Externa e Cooperação Sul-Sul em Saúde: Elementos para Reflexão sobre o Caso do Brasil. In GADELHA, P.; CARVALHO, J. N. de; PEREIRA, T. R. A saúde no Brasil em 2030. Volume 1. Rio de Janeiro: Fiocruz/Ipea/Ministério da Saúde/SAE, 2013.

BUZAN, Barry. New Patterns of Global Security in the Twenty-First Century. International Affairs, Vol. 67, No 3, Jul. 1991, p. 431-451.

CHASE-DUNN, C., NIEMEYER, R.; ALLISON, J. Futures of biotechnology and geopolitics. IROWS Working Paper 23, v. 5-31-06, 2005.

DALBY, Simon . Environmental Change. In: WILLIAMS, Paul D. Security Studies. London: Routledge, 2008.

FIORI, José Luís . Ontem, Hoje e 2030: Tendências do Sistema Mundial - com Ênfase na América do Sul. In GADELHA, P.; CARVALHO, J. N. de; PEREIRA, T. R. A saúde no Brasil em 2030... Volume 1. Rio de Janeiro: Fiocruz; Ipea; Ministério da Saúde; SAE, 2013.

FIORI, J. L.; PADULA, R.; VATER, M.C. A projeção do Brasil na América do Sul e na África Subsaariana e o controle da Bacia do Atlântico Sul. In: CENTRO DE GESTÃO E ESTUDOS ESTRATÉGICOS. Dimensões estratégicas do desenvolvimento brasileiro: Brasil, América Latina e África: convergências, geopolítica e estratégias de integração. Brasília, DF: CGEE, 2013, Volume 3, 288 p. 
GADELHA, Carlos A. G.; COSTA, Laís S. A saúde na política nacional de desenvolvimento: um novo olhar sobre os desafios da saúde. In GADELHA, P.; CARVALHO, J. N. de; PEREIRA, T. R. A saúde no Brasil em 2030... Volume 1. Rio de Janeiro: Fiocruz; Ipea; Ministério da Saúde; SAE, 2013.

GILPIN, Robert Global Political Economy. Princeton University Press, 2001.

GRANATO, Leonardo A integração na América do Sul em discussão nos governos do Brasil e da Argentina (2003-2010). Tese de Doutorado em Economia Política Internacional, Universidade Federal do Rio de Janeiro. Rio de Janeiro, 2014.

IMS HEALTH. IMS Health Market Prognosis, June 2013.

KRASNER, Stephen Structural Conflict. Los Angeles: University of California Press, 1985. KRASNER, Stephen Power, the State and Sovereignty - Essays on international relations. New York, Routledge, 2009.

MCINNES, Colin . Health. In WILLIAMS, Paul D. (Ed.). Security Studies, an introduction. London: Routledge, 2008.

MEDEIROS, Carlos A. de O Desenvolvimento Tecnológico Americano no Pós-Guerra como um Empreendimento Militar. In FIORI, J.L. (Org). O poder americano. Petrópolis: Vozes, 2004

MEDEIROS, C. A. de, TREBAT, N. Military Modernization in Chinese Technical Progress and Industrial Innovation. World Keynes Conference, Izmir Economics University, 26-29th June 2013.

PADUlA, R., NORONHA, G., MITIDIERI, T. Complexo Econômico-Industrial de Saúde, Segurança e Autonomia Estratégica: para pensar a inserção do Brasil frente ao mundo. Saúde Amanhã: Textos para discussão nº 4. Rio de Janeiro: FIOCRUZ, 2015.

PADULA, R. A cooperação em saúde no BRICS: uma perspectiva econômica e política brasileira. In: COSTA, D.; GONÇALVES, W. (OrgS.). Brasil nos BRICS. Rio de Janeiro: Capax Dei, 2015, p. 165-183.

REIS C., LANDIN, A., PIERONI, J.P. Lições da experiência internacional e propostas para incorporação da rota biotecnológica na indústria farmacêutica brasileira. BNDES Setorial 34, 2011, p. 5-44

REIS, Renata; FARIA, Janaína E. P.. Apreensões de medicamentos genéricos e a condenação da UE no Tribunal Permanente dos Povos. Pontes, Vol.6, No 5, 22/12/2010.

THOMAS, Caroline . Poverty. In WILLIAMS, Paul D (Ed.). Security Studies, an introduction. London: Routledge, 2008.

VARGAS, M. A. Indústria de Base Química no Brasil: potencialidades, desafios e nichos estratégicos. In Gadelha, C.; NORONHA, J.C.; PEREIRA, T.R. Brasil Saúde Amanhã: Complexo Econômico Industrial da Saúde. No prelo. 2017 


\title{
Política externa independente e a institucionalização das atividades espaciais no Brasil: histórias cruzadas
}

\author{
Independent Foreign Policy and the institutionalization \\ of space activities in Brazil: intersecting stories
}

DOI: $10.21530 /$ ci.v12n2.2017.660

Renata Corrêa Ribeiro ${ }^{1}$

\section{Resumo}

O primeiro país a se lançar ao cosmos foi a União Soviética, ao lançar o satélite Sputnik I, em 1957. A partir de então, o espaço se tornou a nova fronteira para a projeção de prestígio nacional e poderio dos Estados, principalmente EUA e URSS. Posteriormente, diversas nações desenvolveram a tecnologia e passaram a disputar com as duas superpotências o domínio da ciência e do acesso ao espaço. O Brasil foi um dos pioneiros, entre os países em desenvolvimento, a se inclinar para as ciências espaciais. Em 1961, ainda durante o governo de Jânio Quadros, o programa espacial brasileiro começou a tomar uma forma institucionalizada, com a preocupação com a formação de cientistas e o estabelecimento de uma infraestrutura física com institutos de pesquisa e centros de lançamento. Questiona-se, no entanto, o motivo pelo qual as atividades espaciais terem sido iniciadas no Brasil em 1961. O objetivo deste artigo é, portanto, apresentar as razões que levaram à institucionalização das atividades espaciais durante a curta gestão de Jânio Quadros, a partir da criação do GOCNAE, em 1961. Argumenta-se que o caráter arrojado da política externa instituída por esse presidente, a chamada "Política Externa Independente”, possibilitou uma atuação mais pragmática em relação às ciências espaciais.

Palavras-chave: Programa Espacial Brasileiro; Política Espacial; Política Externa Independente; PEI; Jânio Quadros; Yuri Gagarin; GOCNAE

\footnotetext{
Abstract

The first country to enter the Space Age was the Soviet Union (USSR), when it launched the Sputnik I satellite in October 1957. Thereafter, space became the new frontier for projecting the United States and Soviet Union's prestige and power. Subsequently, many nations started

1 Instituto de Relações Internacionais da Universidade de Brasília, em Brasília/DF, Brasil. E-mail: renata.cori@gmail.com. Artigo submetido em 27/03/2017 e aprovado em 24/08/2017.
} 
developing space technology and to challenge both superpowers in the control of space science and in the access to the outer space. Brazil was one of the first developing countries to lean towards the space sciences. In 1961, during Jânio Quadros's term, Brazilian space program took an institutionalized form, as the concern about scientists' formation and a physical infrastructure's deployment with research centers and launch sites showcase. However, the most frequent question is why the space activities started in Brazil in 1961. Therefore, the aim of this article is presenting the reasons that lead to the institutionalization of space activities during Janio Quadros' term, by creating GOCNAE. One of the main arguments is that the audacious nature of its foreign policy, the Independent Foreign Policy, enabled a more pragmatic behavior with regard to the space sciences.

Keywords: Brazilian Space Program; Space Policy; Independent Foreign Policy; IFP; Jânio Quadros; Yuri Gagarin; GOCNAE

\section{Introdução}

No dia 4 de outubro de 1957, a União Soviética (URSS) apresentou seu pioneirismo em assuntos do espaço exterior ao pôr em órbita o primeiro satélite artificial do mundo, o Sputnik I. Quatro anos mais tarde, novamente a URSS impactou o mundo ao enviar Yuri Gagarin ao espaço, a bordo da nave Vostok. Os dois acontecimentos deram início à Era Espacial, impulsionada, principalmente, pelo clima de competição entre as duas superpotências da época, Estados Unidos (EUA) e União Soviética.

O Brasil foi um dos primeiros países em desenvolvimento a se entusiasmar pelas ciências espaciais. As notícias que chegavam da URSS e dos EUA ajudaram a projetar um pequeno grupo de brasileiros interessados em desenvolver pesquisas e tecnologias espaciais no país. O grupo ganhou prestígio e acabou influenciando fortemente o presidente Jânio Quadros a criar a primeira instituição oficial brasileira encarregada de estruturar o órgão que cuidaria dos assuntos referentes ao espaço, o Grupo de Organização da Comissão Nacional de Atividades Espaciais (GOCNAE), instituído pelo Decreto n. 51.133, de 3 de agosto de 1961.

A postura decisiva de Quadros nessa matéria foi influenciada, sobretudo, pela adoção de uma nova forma de fazer política externa no Brasil: a Política Externa Independente (PEI), iniciada por Jânio Quadros e Afonso Arinos, seu chanceler. As diretrizes básicas da PEI permitiam uma maior abertura das relações do Brasil com os países do mundo, a despeito de suas opções ideológicas e vinculações 
políticas. Nesse sentido, houve uma tentativa de conduzir o Brasil à sua posição de direito no jogo das grandes nações².

Para alcançar seu intento, Jânio Quadros convenceu-se que desenvolver as ciências espaciais internamente traria grandes benefícios ao país. A articulação com civis e militares brasileiros interessados nas atividades espaciais deu início a um rápido processo que culminou na publicação do decreto de criação do GOCNAE. A visita ao Brasil do soviético Yuri Gagarin, primeiro homem a ir ao espaço, entre 29 de julho e 2 de agosto do mesmo ano, teve, também, um grande peso na decisão do presidente da República. A sua importância pode ser comprovada em diversas correspondências e jornais da época.

O objetivo deste artigo é, portanto, demonstrar como a institucionalização das atividades espaciais no Brasil está intimamente ligada à nova forma de fazer política externa formulada por Jânio Quadros, a Política Externa Independente (PEI). Argumenta-se que o caráter arrojado de sua política externa possibilitou uma atuação mais pragmática em relação às ciências espaciais. Em menos de sete meses, Quadros recebeu conselhos de especialistas na área espacial, recepcionou Gagarin no Brasil e publicou decreto que instituía o grupo de organização da comissão responsável pelas atividades espaciais.

Para isso, a autora optou pelo seguinte arranjo para apresentar o problema de pesquisa: na primeira seção, será feita uma apresentação das diretrizes gerais da PEI, formuladas durante a gestão Quadros-Arinos, dando enfoque nas razões de sua criação; a segunda seção será responsável por fazer um resgate histórico dos eventos e instituições que abriram caminho para a institucionalização das atividades espaciais no início dos anos 1960; e, por fim, a terceira seção apresentará os fatos e motivos que levaram o presidente Jânio Quadros a tomar tal atitude.

\section{O caráter arrojado da Política Externa Independente de Jânio Quadros}

Em sua curta gestão como Presidente (exatamente seis meses e 6 dias $^{3}$ ), Jânio Quadros inaugurou o conjunto de iniciativas de uma nova vertente de política

2 O trecho do artigo de Jânio, publicado na Foreign Affairs de 1961, demonstra isso: "Interesse demonstrado na posição do Brasil em assuntos internacionais é, em si mesmo, uma prova da presença de uma nova força no cenário mundial [...] Somos uma nação de proporções continentais, ocupando quase a metade da América do Sul [...] Dentro da próxima década nossa população atingirá perto de cem milhões de habitantes e a rápida industrialização de algumas regiões do país faz prever a nossa transformação em uma potência econômica [...] Se somente agora o Brasil está sendo ouvido em assuntos internacionais, é porque, ao assumir o poder, resolvi tirar proveito das consequências da posição que atingimos como nação” (QUADROS, 1961, p.1).

3 Jânio Quadros governou o Brasil de 31 de janeiro de 1961 a 25 de agosto de 1961. 
externa que, posteriormente, foi sistematizada e aprofundada por San Tiago Dantas (Ministro das Relações Exteriores do presidente João Goulart), que a batizou de “Política Externa Independente”. Apesar de não representar uma inovação completa, pois apenas continuava e aprofundava uma política externa mais autônoma iniciada em Vargas, como afirmou Visentini (2009), ela apresentava um conjunto de noções e atitudes independentes e articuladas, além de ter um conteúdo mais sistêmico.

Tanto Visentini (2009, p. 123) quanto Álvares (1989, p. 58-59) concordam que as razões para o caráter arrojado da política externa de Jânio Quadros encontram suas origens em circunstâncias internas e externas. Internamente, o país havia passado por uma grande transformação, tanto econômica quanto socialmente. O êxodo rural atingiu seu auge, deslocando enormes contingentes populacionais para as cidades; o setor industrial (fortemente estimulado pelo Plano de Metas de Juscelino Kubitschek) ultrapassou o setor agrícola em valor e importância econômica para o país; o mercado interno se ampliou, assim como se intensificaram as desigualdades sociais e regionais. Tudo isso levou o país a uma crise socioeconômica preocupante (VISENTINI, 2009, p. 124; ÁlVARES, 1989, p. 58-59).

A diminuição dos preços dos produtos primários exportados pelo Brasil foi o grande vilão da economia naquele momento. Com o desequilíbrio da balança comercial, as divisas atingiram um nível extremamente baixo, enquanto as remessas de lucros para o exterior só cresciam. Somado a isso, a sociedade convivia com alto desemprego, alta inflação e a baixa de salários. Assim, apesar da extraordinária transformação ocorrida na economia nos anos de Kubitschek, sabia-se que ainda havia uma forte dependência externa. O próprio Jânio Quadros, em seu artigo na Foreign Affairs, deixou transparecer sua insatisfação com o jogo que as grandes potências ainda faziam com as nações em desenvolvimento ${ }^{4}$.

A nova política externa era uma tentativa de reverter o quadro desfavorável enfrentado pelo Brasil internamente. Visentini (2009, p. 126) observa que entre as bases internas da PEI estavam a articulação de um projeto de desenvolvimento comum para enfrentar a crise vivida somada às necessidades externas do país, que geravam estagnação econômica (exportação dos produtos primários, obtenção de divisas para importação de bens de capital, investimentos em tecnologias estrangeiras etc.).

4 "Não estamos em posição de permitir a liberdade de ação de forças econômicas em nosso território, simplesmente porque essas forças, controladas do exterior, fazem o seu próprio jogo e não o de nosso país” (QUADROS, 1961, p. 5). 
A forte dependência do Brasil suscitava uma mudança imperiosa na política externa, que tinha a função de corrigir os numerosos desequilíbrios econômicos, que tem na balança de pagamentos um dos maiores exemplos. Nesse sentido, a ampliação de mercados para as exportações brasileiras torna-se essencial para conter as instabilidades econômicas e a diversificação de parcerias, um dos alicerces da nova política externa gestada por Quadros.

Para Wrobel (1993, p. 195), as mudanças introduzidas pela dupla QuadroArinos previam meios de se obter o desenvolvimento mais rapidamente. A forma encontrada para se alcançar esse intento foi utilizar uma postura mais agressiva na conquista de novos mercados e na ampliação das relações comerciais com o resto do mundo. Após décadas de forte dependência do mercado norte-americano, a nova gestão optou por restabelecer relações diplomáticas e comerciais com países que apresentavam a possibilidade de absorver os principais produtos exportados pelo Brasil.

Tudo isso só foi possível devido à conjunção com fatores externos. A URSS dos anos 1960 havia se transformado, dominando a posição de potência econômica e tecnológica, como o lançamento do primeiro satélite artificial da Terra, o Sputnik I, em 1957, havia confirmado. Assim, as possibilidades de cooperação financeira, comercial e tecnológicas com os países socialistas se tornaram um grande atrativo para um país enfrentando uma forte crise socioeconômica, como era o caso do Brasil. Além disso, em 1957, o Tratado de Roma cria a Comunidade Econômica Europeia (CEE), que dá preferências para os seis países integrantes do bloco (França, Alemanha, Holanda, Itália, Luxemburgo e Bélgica), não extensiva aos países de fora. Como consequência, o Brasil enfrenta problemas para exportar para esse continente, que se somava às dificuldades para exportar café para os EUA, já que os dois países não entram em um acordo acerca do preço do produto.

Outra alteração importante no contexto internacional era a emergência de um bloco organizado de países do Terceiro Mundo. A aceleração das descolonizações dos países da África e Ásia deu lugar à união dos países terceiro-mundistas na busca de ideais comuns, como o neutralismo, o afroasiatismo e criação de uma nova ordem mundial, como ficou claro durante a Conferência dos Países Não Alinhados, em 1961 (VISENTINI, 2009, p. 129). Apesar de não participar como membro desse movimento ${ }^{5}$, o Brasil percebia que a ascensão de novos Estados no

5 O Brasil apenas participou como observador enviando o diplomata João Augusto de Araújo Castro. Ele compareceu à Reunião Preliminar e à Conferência de Chefes de Estado e de Governo dos Países Não Alinhados, realizada no Cairo, entre 5 e 13 de julho de 1961 (CERVO; BUENO, 2010, p. 326). 
cenário mundial alterava a configuração das relações internacionais. Acreditava-se que havia uma tendência de se materializar uma nova ordem econômica, política e social de inclusão dos países do Terceiro Mundo nos processos decisórios mundiais.

Após longa reflexão a respeito das conjunturas interna e externa, Jânio Quadros e Afonso Arinos articulam as bases da política externa a ser seguida durante a sua gestão. Na mensagem presidencial enviada ao Congresso Nacional, em 20 de março de 1961, Quadros explicitou as 15 diretrizes gerais e regionais de sua política externa (FRANCO, 2007, p. 49). Cervo (1998, p. 70), no entanto, sintetizou-a em quatro pontos principais: 1) o abandono da subserviência aos interesses estrangeiros e a busca dos interesses nacionais que levam ao desenvolvimento do país; 2) aproximação de outras nações recém-emancipadas da África e Ásia, assim como da América Latina, para se construir uma frente contra as desigualdades entre as nações; 3 ) inauguração de um pan-americanismo de conteúdo econômico e social, superando a fase política e ideológica; 4) a liberdade de o Brasil não se vincular a nenhum bloco ou ideologia, mantendo-se neutro na Guerra Fria, mantendo relações diplomáticas e comerciais com todas as nações do mundo, a despeito de sua vinculação ideológica.

Nesse sentido, depreende-se que Jânio Quadros usava a política externa como instrumento a serviço da resolução de problemas internos (CERVO; BUENO, 2010, p. 327). A liberalidade da política de Quadros possibilitou uma aproximação com a URSS e outros países socialistas. O objetivo, contudo, era retirar dessas relações somente aquilo que poderia ser positivo ao Brasil. E essa relação de pragmatismo pode ser comprovada na área das ciências. Entusiasmado com o pioneirismo soviético na área espacial - como mostrou o lançamento do Sputnik I -, Quadros convenceu-se de que não podia deixar de se aproximar daquele país, que poderia trazer muitos dividendos para o Brasil nessa seara. A recepção de Yuri Gagarin faz parte dessa rede de esforços, estimulada pelo presidente da República, para se institucionalizar as atividades espaciais no país. Ela, no entanto, não seria possível sem o caráter arrojado da sua forma de fazer política externa.

\section{A origem das atividades espaciais no Brasil}

O processo de institucionalização das atividades no Brasil relaciona-se com o entusiasmo de uma pequena, mas dedicada comunidade científica brasileira, que trabalhava arduamente pelo progresso científico e tecnológico do país desde 
os anos de 1930. A inserção do Brasil nesse novo campo esteve ligada, no início, à pesquisa e ao desenvolvimento no ramo da energia nuclear. Como aponta Sato (2013, p. 815), a comunidade científica brasileira preocupava-se em “integrar-se aos avanços em curso na ciência no mundo, e a capacitação na área de energia nuclear se afigurava como algo de importância primordial”.

Especificamente no campo das aplicações espaciais, o interesse do Brasil surgiu dentro de instituições militares, de forma similar à grande parte de outros países. Em 1941, com a criação do Ministério da Aeronáutica, em meio à Segunda Guerra Mundial, o Brasil também pôde iniciar sua caminhada que, nesse primeiro momento, visava apenas a fundação de um centro de pesquisas capaz de desenvolver tecnologias militares.

Quando se iniciaram as hostilidades que culminaram na Segunda Guerra Mundial (1939-1945), o governo de Getúlio Vargas declarou sua neutralidade, apesar de essa neutralidade ter sido violada diversas vezes em função da incapacidade militar brasileira em vigiar seu litoral (CERVO; BUENO, 2010, p. 249). O interesse norte-americano em aproximar-se do país para obter vantagens da posição geográfica brasileira e de seus minerais estratégicos estimulou o início de um programa de aproximação aeronáutica. Diversos militares brasileiros foram enviados a instituições de renome estadunidenses para consolidarem seu aprendizado e incorporarem novos conhecimentos ao país, que assistia atento aos desdobramentos da guerra.

A interação entre militares brasileiros e norte-americanos - principalmente no front, após a declaração de guerra do Brasil contra o Eixo, em 1942, que enviou tropas para lutar ao lado dos Aliados no norte da África - somada à falta de capacidade militar do país levaram a reflexões acerca dos principais gargalos que impediam o Brasil de atingir seus objetivos militares: a necessidade de criação de instituições para formação e capacitação de militares, de órgãos de coordenação de atividades operacionais, além de estimular o surgimento de uma indústria nacional (ESCADA, 2005, p. 39). Nos últimos anos da Segunda Guerra, era patente a urgência de se empreender um programa de desenvolvimento científico e tecnológico no país. Objetivava-se fundar um centro técnico de pesquisas com a finalidade de desenvolver a tecnologia militar.

Em 1945, um grupo de oficiais da Força Aérea Brasileira (FAB) realizou algumas visitas a instituições norte-americanas de excelência e a bases aéreas. O objetivo da visita era conhecer centros de pesquisa que pudessem ajudar a desenvolver o modelo de uma instituição científica e tecnológica para o Brasil. Decidiu-se, 
então, que o centro técnico da Aeronáutica replicaria o modelo do Massachussets Institute of Tecnology (MIT), e o Brasil, inclusive, contaria com o apoio do chefe do departamento do referido instituto (ESCADA, 2005, p. 47).

Após meses discutindo o plano de criação de um centro técnico, em janeiro de 1946, foi aprovada a Comissão de Organização do Centro Técnico da Aeronáutica (COCTA). A Comissão foi extinta em 1953, quando cumpriu sua missão de executar o plano de institucionalização do Centro Técnico da Aeronáutica (CTA), que iniciou suas atividades no primeiro dia de 1954 em São José dos Campos, São Paulo. O CTA era uma instituição científica e técnica de pesquisa da Força Aérea Brasileira. Como centro de pesquisa, sua atribuição inicial era a de formação de cientistas para o desenvolvimento da tecnologia aeronáutica (COSTA FILHO, 2002, p. 69-69). Esse era o primeiro passo para superar as deficiências do poder aéreo brasileiro.

Nesse primeiro momento, o Brasil contou com a cooperação dos EUA parceiro militar desde 1940 - para a montagem da infraestrutura de apoio para o desenvolvimento de pesquisas ${ }^{6}$, além da colaboração do chefe do departamento de Aeronáutica do MIT, professor Richard H. Smith. Foram criados dois institutos científicos: o Instituto Tecnológico da Aeronáutica (ITA), voltado para a ensino superior qualificado; e o Instituto de Pesquisa e Desenvolvimento (IPD), que se concentrava na pesquisa e na cooperação com a indústria.

A criação do ITA, em 1948, foi um marco na formação de mão de obra especializada para o setor aeroespacial. No início, foram disponibilizados os cursos de engenharia aeronáutica de aeronaves, aerovias e eletrônica. O objetivo era suprir a demanda do mercado por recursos humanos qualificados, o que estava diretamente ligado ao desenvolvimento tecnológico do setor. Para compor o quadro de técnicos e professores - ainda indisponíveis no Brasil -, foi necessária a contratação no exterior, como nos Estados Unidos ${ }^{7}$ e Alemanha ${ }^{8}$.

Inicialmente, os engenheiros formados no ITA encontraram difícil inserção no mercado tecnológico brasileiro, devido à falta de um setor produtivo apto a

6 Segundo Costa Filho (2002), o Brasil comprou "equipamentos e material para os laboratórios de motores, estruturas, metalografia, resistência dos materiais e de máquinas e ferramentas, além de uma parte dos livros que iriam integrar o acervo da biblioteca do ITA".

7 Com a falta de técnicos e professores qualificados no Brasil, previa-se que a maioria dos professores seriam norte-americanos altamente capacitados, contratados por um período de quatro anos, renováveis por mais três. Após esse período, os norte-americanos seriam substituídos por brasileiros, preferencialmente os formados no instituto (ESCADA, 2005, p. 52).

8 Um dos nomes mais importantes é o do Prof. Henrich Focke, um dos fundadores da fábrica de aviões alemã Focke Wulf. Em 1951, o professor alemão mudou-se para o Brasil acompanhado de 20 técnicos de equipe (COSTA FILHO, 2002, p. 72-73). 
integrar a mão de obra altamente qualificada dos recém graduados no instituto. No entanto, esses engenheiros possibilitaram o abastecimento da nascente indústria bélica brasileira, localizada no Vale do Paraíba (COSTA FILHO, 2002, p. 73).

Após a completa consolidação do ITA, os esforços foram concentrados na instalação do segundo instituto científico previsto no plano do CTA: o Instituto de Pesquisa e Desenvolvimento (IPD). Em 1953, o Ministério da Aeronáutica, ciente da necessidade de se criar uma infraestrutura técnico-científica para apoiar o nascente parque industrial, criou o IPD. O novo instituto teria a função de investigar os entraves técnicos, econômicos e, principalmente, operacionais relacionados à Aeronáutica; cooperar com a nascente indústria de tecnologias; e examinar soluções adequadas às atividades da aviação nacional (ESCADA, 2005, p. 53). Em suma, o instituto seria responsável pelas pesquisas científicas e tecnológicas para impulsionar o desenvolvimento do setor no Brasil.

Nos primeiros anos do instituto, as atividades se concentraram no desenvolvimento de pesquisas de tecnologias para o setor aéreo. Com a coordenação dos professores e técnicos estrangeiros, foram desenvolvidos protótipos de novas aeronaves e helicópteros, como o Convertiplano ${ }^{9}$ e o Beija-Flor ${ }^{10}$. Posteriormente, as notícias vindas do exterior de que EUA e União Soviética (URSS) estavam a desenvolver satélites e os lançariam ao espaço entusiasmaram militares da Aeronáutica, além de alunos e professores dos dois institutos. Com isso, no final da década de 1950, iniciaram-se as primeiras pesquisas ligadas ao ramo espacial.

É importante ressaltar que o interesse pelo desenvolvimento científico e tecnológico no Brasil não se restringia à área aeroespacial. Personalidades, como o almirante Álvaro Alberto, foram grandes promotores da ciência e tecnologia de ponta no país. Nesse sentido, no início dos anos de 1950, concebeu-se a ideia de que era necessário criar uma instituição que impulsionasse as atividades científicas no Brasil, resultado natural do acompanhamento, por um grande número de cientistas brasileiros, do que vinha sendo desenvolvido no mundo. Assim, em 1951, foi criado o Conselho Nacional de Pesquisas (CNPq), um conselho de alto nível que trabalhava diretamente com a cúpula governamental para se criar uma política científica para o país (SATO, 2013, p. 819). A partir desse momento, os

9 O Convertiplano era um projeto de aeronave de decolagem vertical de autoria do professor Focke (ESCADA, 2005, p. 54).

10 O Beija-Flor era o projeto de um helicóptero para duas pessoas, também de autoria do professor Focke. O projeto tinha um desenvolvimento mais simples que o Convertiplano, razão pela qual se previa a sua industrialização (ESCADA, 2005, p. 54). 
desenvolvimentos científico e tecnológico do país transformavam-se em uma política de Estado.

Em 1957, a imprensa internacional divulgava, com bastante entusiasmo, que o Ano Geofísico Internacional (no ano seguinte, em 1958) seria dominado pelo lançamento de satélites artificiais por parte de russos e norte-americanos. No Brasil, dois estudantes de engenharia do ITA - Fernando de Mendonça e Júlio Alberto de Morais Coutinho -, contando com o apoio do presidente do IPD, o Coronel Aldo Weber Vieira da Rosa, tiveram a iniciativa de construir uma estação de rastreio dos satélites americanos do Projeto Vanguard. A estação foi batizada com o nome de Minitrack Mark II. Os satélites do projeto Vanguard estavam sendo desenvolvidos pelo Laboratório de Pesquisa Naval da Marinha dos EUA. Naquele momento, ainda se acreditava que os norte-americanos seriam os pioneiros na conquista espacial (ESCADA, 2005, p. 55; COSTA FILHO, 2002, p. 74).

Houve uma grande preparação para acompanhar o lançamento e funcionamento do primeiro satélite artificial, com a presença de pessoas e entidades militares e civis, da Aeronáutica e da Sociedade Interplanetária Brasileira (SIB). Os equipamentos necessários foram doados pelo governo norte-americano e todos ficaram à espera do grande acontecimento.

Entretanto, como é sabido, o primeiro satélite artificial do mundo foi produzido e lançado pela União Soviética, o Sputnik-I, em 4 de outubro de 1957, data em que se convencionou dizer que começou a Era Espacial (GOUVEIA, 2003, p. 3). Imediatamente, o grupo brasileiro realizou ajustes no sistema da estação e mudou a posição dos aparelhos, dirigindo-os para o satélite soviético. Consta que o acompanhamento foi feito com sucesso. Em janeiro de 1958, a estação também recebeu os dados do Explorer I, o primeiro satélite norte-americano a ser posto na órbita na Terra.

Esse grupo de pessoas e instituições inaugurou as atividades espaciais no Brasil. Com o sucessivo desenvolvimento da corrida espacial entre a União Soviética e os EUA, o grupo brasileiro só teve razões para manter e seguir adiante com o trabalho iniciado. Em 1959, Fernando de Mendonça, um dos estudantes de engenharia do ITA a construir a estação para receber dados do Sputnik I, foi fazer doutorado na Universidade de Stanford, nos EUA, e atuou em projetos da NASA, a Agência Espacial Norte-Americana ${ }^{11}$. Todavia, continuou atuando em

11 A NASA, sigla em inglês para National Aeronautics and Space Administration, é uma agência estatal dos Estados Unidos, responsável por implementar a política especial norte-americana. A agência foi criada em 1958, em substituição à NACA, National Advisory Committee for Aeronautics. 
estreita colaboração com o coronel Aldo Weber Vieira da Rosa para a criação de uma instituição voltada particularmente para a área espacial, que já vinha sendo discutida no seio da Aeronáutica e da Sociedade Interplanetária Brasileira (ESCADA, 2005, p. 56).

Nos primórdios dessa instituição está o Comitê Interamericano de Pesquisas Espaciais, criado após a realização da Reunião Interamericana de Pesquisas Espaciais, ocorrida em dezembro de 1960 na Argentina. Um dos objetivos desse comitê era estimular a criação de entidades governamentais voltadas exclusivamente para a área espacial nos países participantes. O presidente da SIB, Luiz de Gonzaga Bevilacqua, foi o participante brasileiro do Comitê e terá uma forte influência na criação da nova instituição brasileira, que tomará forma durante a gestão de Jânio Quadros (ESCADA, 2005, p. 56).

\section{A influência de Jânio Quadros e de sua Política Externa Independente na institucionalização das atividades espaciais no Brasil}

Jânio Quadros foi empossado como presidente da República no dia 31 de janeiro de 1961. Ele foi o presidente a inaugurar a institucionalização das atividades espaciais no Brasil, o que encontra razões em três fatores primordiais: a proximidade de Quadros com membros da SIB, que os permitiu exercerem influência direta sobre o presidente; a visita do russo Yuri Gagarin ao Brasil, primeiro ser humano a ir ao espaço; e, principalmente, seu comprometimento com o desenvolvimento das ciências no Brasil, que ultrapassava, até mesmo, os condicionantes ideológicos da Guerra Fria.

A conjunção de interesses em torno das questões espaciais, que unia estudantes do ITA, militares e associações, como a SIB, rendeu frutos, resultando na decisão de sensibilizar o presidente da República para as causas espaciais.

No dia 20 de fevereiro de 1961, Jânio Quadros recebeu do professor Luiz Gonzaga Bevilacqua, de quem era amigo pessoal (ESCADA, 2005, p. 47), uma carta assinada por ele e por Thomas Bun, ambos da SIB. Nessa carta, os dois sugeriam a criação de uma instituição voltada para as pesquisas espaciais no Brasil, afirmando que o país não podia ficar de fora dessas atividades. De acordo com Gatto (2010, p. 33), a carta deixava claro que "este seria o primeiro passo, a primeira manifestac „ão objetiva e pública do interesse do Governo do Brasil pelos problemas fascinantes da astronáutica, exatamente quando a humanidade se 
encontra no 40 ano da Era do Espac so”. Ao perceber a importância que Quadros havia dado a esse assunto, os militares da Aeronáutica juntaram-se aos civis no movimento em prol de uma entidade para fins puramente espaciais.

Segundo Santos (2005, p. 140), o presidente então enviou uma carta para o chefe da Casa Militar da Presidência da República, o general Ernesto Geisel, que convocou o coronel Aldo Weber Vieira da Rosa, do CTA, para tratar do assunto. Nas discussões entre os membros da SIB, a Aeronáutica e a Presidência da República foi sugerida a criação de uma instituição para cuidar da pesquisa espacial brasileira.

O tema ganhou ainda mais força após o feito inédito do russo Yuri Gagarin, que fez a primeira viagem pelo espaço, no dia 12 de abril de 1961. A imprensa brasileira noticiou o acontecimento em primeira página, esquecendo a tradicional rivalidade da Guerra Fria e concentrando-se em admirar a importância que esse fato significava para a humanidade ${ }^{12}$. O feito de Gagarin causou consternação no Brasil, sendo o primeiro cosmonauta classificado como "herói" em muitos meios.

A façanha extraordinária de Gagarin, que não encontrava precedentes até aquele momento, motivou o presidente Jânio Quadros a nomear, no dia 17 de maio de 1961, uma comissão composta por personalidades empenhadas no estabelecimento da instituição: coronel Aldo Weber Vieira da Rosa, diretor do CTA; almirante Otacílio Cunha, presidente do CNPq (Conselho Nacional de Pesquisas); e Luiz Gonzaga Bevilacqua e Thomas Bun, presidentes da SIB. No dia 15 do mês seguinte, a comissão encaminhou parecer com a sugestão de criar um Grupo de Organização da Comissão Nacional de Estudos Espaciais, que ficaria subordinado ao CNPq. A função dessa instituição seria de formar recursos humanos qualificados e desenvolver atividades nas áreas ligadas às ciências espaciais (ESCADA, 2005, p. 49).

A rapidez com que os ritos internos estavam sendo conduzidos para a institucionalização da entidade deixavam claro o entusiasmo de Jânio Quadros com as ciências espaciais. Motivado pelo frenesi do momento em torno dos grandes feitos na área, principalmente pelos dois maiores competidores, EUA e URSS, Jânio Quadros optou por não ficar de fora da corrida pela aquisição de tecnologia de ponta. Imbuído de um desejo de libertação da dependência tradicional com os norte-americanos, Quadros parecia querer afrontá-los e demonstrar que poderia seguir um rumo próprio. O presidente da República estava convicto que o Brasil

12 O Correio da Manhã do dia 13 de abril, por exemplo, enfatizava, em sua primeira página, a primeira frase dita pelo cosmonauta: “O céu é muito escuro e a Terra azulada”. Já o Estado de São Paulo do mesmo dia noticiava: "Astronauta soviético enviado ao espaço regressa depois de circundar a Terra: a humanidade entra na Idade Cósmica”. (CORREIO DA MANHÃ, 1961ª; ESTADO DE SÃO PAULO, 1961) 
era uma nação de grande relevância no jogo das potências mundiais e que, por isso, deveria demonstrar seu poderio e capacidade com o desenvolvimento interno das tecnologias espaciais.

Sabendo disso, o Instituto Brasileiro de Astronáutica e Ciências Espaciais (IBACE), sediado em SP, enviou uma carta ao presidente da República sugerindo convidar o cosmonauta Yuri Gagarin para uma visita ao país (CORREIO DA MANHÃ, 1961b, 1961e; FOLHA DE SÃO PAULO, 1961a, 1961b, 1961e). Dois dias depois, a imprensa brasileira noticiou que Jânio Quadros animou-se com a ideia e estava disposto a convidar Yuri Gagarin para vir ao Brasil na qualidade de hóspede oficial do governo (CORREIO DA MANHÃ, 1961c). De fato, a viagem de Gagarin representava o atendimento de um desejo pessoal do presidente da República, manifestado, também, durante seu encontro com a Missão Soviética da Boa-Vontade (JORNAL DO BRASIL, 1961a). Posteriormente, o prof. Flávio A. Pereira, do IBACE, dirigiu a carta-convite ao Comitê de Estado soviético ${ }^{13}$.

A visita de Gagarin ocorreu entre os dias 29 de julho e 2 de agosto de 1961, após sua passagem por Londres ${ }^{14}$, Varsóvia e Havana, locais onde o cosmonauta foi ovacionado durante sua estada. Durante os preparativos para a recepção do soviético, Jânio Quadros determinou ao Itamaraty e a entidades científicas que recebessem o astronauta e promovessem palestras e conferências, o que julgava de grande importância para a ciência brasileira. "Parece-me do mais alto interesse para os nossos meios científicos palestras e conferências desse astronauta”, afirmou Quadros em memorando presidencial dirigido aos ministros da Educação e da Aeronáutica e ao Conselho Nacional de Pesquisas (ÚLTIMA HORA, 1961a).

Gagarin desembarcou no Rio de Janeiro no dia 29 de julho, onde foi recebido com honras militares pelo almirante Otacílio Cunha, presidente do CNPq, e outras personalidades militares. A chegada de Gagarin foi marcada por aglomerações,

13 Texto integral do convite reproduzido na primeira página pela Folha de São Paulo do dia 28 de julho de 1961 com o seguinte teor: "Tenho a honra de convidar o major Yuri Gagarin para visitar o Brasil e aqui proferir uma conferência sobre a memorável viagem orbital que realizou em 12 de abril de 1961 a bordo da cosmonave Vostok. Faço esse convite na qualidade de diretor-presidente do Instituto Brasileiro de Astronáutica e Ciências Espaciais, de São Paulo. Tomo a liberdade de formular o anteprojeto de programa da visita do comandante Gagarin, no qual está incluído um encontro no Palácio do Planalto com o Sr. Presidente da República, Dr. Jânio Quadros. A aceitação do convite poderia ser feita através do Instituto União Cultural Brasil-URSS, de São Paulo"(FOLHA DE SÃO PAULO, 1961c).

14 "Em sua chegada a Londres, Gagarin foi recepcionado com muitos aplausos em um trajeto de cerca de $24 \mathrm{Km}$. Na Exposição Comercial Soviética, mais de mil pessoas rodearam o cosmonauta, causando tumulto e desconforto para o russo. As proporções da manifestação se tornaram superiores às possibilidades dos guardas para protegêlo. Algumas mulheres desmaiaram, as crianças tiveram que ser carregadas por seus pais para evitar que fossem pisoteadas. Houve gritos de pânico”. Relato da visita a Londres pelo Jornal do Brasil do dia 12 de julho de 1961. 
tumulto e violência contra a imprensa (FOLHA DE SÃO PAULO, 1961e). Jânio Quadros, que estava em viagem a São Luiz, no Maranhão, para a VI Reunião de Governadores, revelou em entrevista que considerava a visita de Yuri Gagarin "da mais significativa importância para o Brasil" e que "não tinha dúvidas que suas palestras seriam de grande utilidade para todos, pois rasgou estradas e universos, ensejando horizontes para o homem" (JORNAL DO BRASIL, 1961b).

Dada a importância que as ciências haviam alcançado no Brasil, uma das programações no Rio de Janeiro incluía visita à Academia Brasileira de Ciências, no dia 30 de julho. Ali, Gagarin foi recebido pelo almirante Otacílio Cunha e Arthur Moses, presidente da Academia Brasileira de Ciências, onde permaneceu por uma hora, respondendo a perguntas de cientistas interessados na aventura do soviético no espaço.

No dia seguinte, em São Paulo, foi recebido pelo governador Carvalho Pinto, que concedeu ao astronauta o diploma de Sócio Honorário da SIB. O presidente da SIB, Thomas Bun, entregou-lhe também uma carta, endereçada à Academia de Ciências da URSS, objetivando o estreitamento do intercâmbio científico entre as entidades dos responsáveis pelas pesquisas espaciais dos dois países. Posteriormente, Gagarin proferiu uma conferência no Instituto Municipal de Astrofísica de São Paulo (JORNAL DO BRASIL, 1961c; FOLHA DE SÃO PAULO, 1961d).

O último dia de sua visita foi reservado para o encontro com o presidente da República em Brasília. Em solenidade no Palácio do Planalto, Gagarin foi condecorado com o grau de Comendador da Ordem do Mérito Aeronáutico pelo presidente Jânio Quadros, em uma homenagem que contou com a presença de todos os funcionários do Palácio ${ }^{15}$ (CORREIO DA MANHÃ, 1961d).

$\mathrm{O}$ astronauta soviético agradeceu ao presidente e entregou-lhe uma mensagem pessoal de Nikita Kruschev, que agradecia a recepção de seu astronauta. Kruschev revelou que considerava o convite a Gagarin "uma manifestação dos sentimentos amistosos do povo do Brasil aos povos da URSS". A mensagem de Kruschev demonstrava o tom cordial da URSS para com o Brasil, resultado das já intensas conversações entre os dois países a respeito do reatamento das relações diplomáticas, que já vinha desde o início do governo Jânio Quadros. Essa era uma das plataformas de Jânio para ampliar a cooperação comercial, científica e tecnológica brasileira

15 Ao conceder a Comenda, Quadros disse que "homenageava o pioneiro de uma era que permitirá maior entendimento entre os homens e a consolidação da paz [...] o Governo Brasileiro deseja exprimir a sua admiração e o seu reconhecimento pelo extraordinário feito científico que tanto notabilizou V. Excelência, o povo e o governo soviético". 
com o mundo. Apesar de todo o esforço e entusiasmo de Jânio Quadros e Afonso Arinos, o reatamento só foi consolidado durante a presidência de João Goulart, no dia 23 de novembro de 1961.

Os EUA acompanharam a visita de Gagarin ao Brasil com grande atenção. O interesse de Jânio Quadros pelo desenvolvimento das ciências espaciais no Brasil já havia sido comunicado aos estadunidenses. Como visto anteriormente, grandes cientistas brasileiros viviam nos EUA e executavam projetos nos institutos de pesquisa americanos, muito em função da carência de centros de pesquisa científicos no país. Temendo que os brasileiros estabelecessem acordos diretos com os soviéticos nesse campo, Jânio recebeu um relatório dos EUA propondo uma cooperação com o uso dos foguetes norte-americanos pouco antes do presidente receber Gagarin no Palácio do Planalto (ÚLTIMA HORA, 1961b). Esse ato simbolizou a preocupação dos EUA com uma eventual aproximação do Brasil com seu principal adversário, a URSS, na área em que se encontravam mais adiantados que os americanos, a espacial. A rapidez e efetividade com que Quadros conduziu o processo de institucionalização era um demonstrativo do desejo de obter independência nessa seara, vital para o progresso de uma nação.

A importância que Jânio Quadros atribuía ao desenvolvimento das ciências espaciais no Brasil, que se expandiu devido ao enorme sucesso provocado pela passagem de Gagarin, comprovou-se com a assinatura do decreto criando o GOCNAE, o Grupo de Organização da Comissão Nacional de Atividades Espaciais, no dia 3 de agosto de 1961, dia seguinte ao retorno do astronauta à URSS. O Decreto 51.133/1961 (BRASIL, 1961) estabelecia suas atribuições, seus objetivos, a composição de seus membros e dava outras providências.

Entre suas atribuições, estava: estudar e compor a Política Espacial Brasileira; preparar o plano de criação da Comissão Nacional das Atividades Espaciais; executar projetos de pesquisas espaciais; firmar acordos relacionados à instalação da sede; gerir as obras e serviços indispensáveis à criação do CNAE (BRASIL, 1961). Em suma, eram dois objetivos: promover a pesquisa espacial civil e coordenar as atividades espaciais (COSTA FILHO, 2002, p. 82).

A primeira composição do GOCNAE foi representada por renomadas personalidades do meio militar e civil já comprometidos com as ciências espaciais: o presidente era o coronel Aldo Weber Vieira da Rosa (Aeronáutica); o Comitê Executivo era composto pelo coronel Alnyr Maurício (Exército), almirante Botelho Machado (Marinha) e coronel Sérgio Sobral de Oliveira (Aeronáutica); o conselho era composto por Luiz Gonzaga Bevilacqua (presidente honorário da SIB), Thomas 
Bun (presidente da SIB) e Lincoln Eduardo de Souza Bittencourt, todos civis e representantes da SIB (ESCADA, 2005, 49).

O alvoroço em torno da renúncia de Jânio Quadros (apenas 22 dias após o decreto de criação do GOCNAE) e da posse do vice, João Goulart, refletiu no início das atividades da organização, que só teve seus membros empossados no dia 22 de janeiro de 1962, seis meses após a publicação do decreto (JORNAL DO BRASIL, 1962). O grupo se reunia no terceiro andar do Aeroporto de Congonhas, em São Paulo, local com acesso facilitado para todos os membros, que se deslocavam de avião de diferentes cidades, como Bauru, São José dos Campos e Rio de Janeiro. Em 45 dias, foi elaborado um documento delineando a trajetória que o Brasil deveria seguir, a começar pela criação da Comissão Nacional de Atividades Espaciais (CNAE) (DA ROSA, 2007).

No plano inicial de trabalho, as áreas prioritárias foram definidas como astronomia, radioastronomia, rastreio ótico de satélites e comunicação por meio de satélites. Como observado por Costa Filho (2002, p. 83), o plano inicial de pesquisas espaciais voltava-se para estudos da ionosfera, geomagnetismo e meteorologia, refletindo projetos já em curso na NASA.

Em função da situação política e econômica do país, houve dificuldade inicial em captar recursos para a institucionalização da entidade. De acordo com informações divulgadas no Última Hora de 19 de fevereiro de 1961, o grupo não dispunha de dinheiro para começar suas pesquisas. "O GOCNAE pediu a abertura de um crédito extraordinário de 50 milhões de cruzeiros e não foi atendido por empecilhos administrativos", afirmou a matéria (ÚLTIMA HORA, 1961c). Os obstáculos iniciais também impediram a criação da CNAE de imediato, como proposto pelo coronel Aldo Weber. Seguiu-se um período de intensa dedicação para persuadir o sucessor, João Goulart, a efetivamente instituir a criação da CNAE (DA ROSA, 2007).

Consequentemente, o CNAE só conseguiu iniciar suas atividades em 1963, em São José dos Campos, dentro das instalações do CTA. O GOCNAE tornou-se CNAE, de fato, em 1964, após o golpe militar. Ele foi extinto em 1971, quando foi substituído pelo Instituto Nacional de Pesquisas Espaciais, o INPE16, o principal órgão de pesquisas civis da área espacial até os dias de hoje. O INPE é a instituição brasileira responsável por promover e efetivar estudos, pesquisas, desenvolvimento tecnológico e capacitar recursos humanos em áreas relacionadas

16 O Decreto n. 68.532 de 22 de abril de 1971 extingue o GOCNAE e cria o Instituto de Pesquisas Espaciais (INPE). 
à ciência espacial, como atmosfera e meteorologia. O foco do INPE é desenvolver a ciência e a tecnologia espacial internamente, considerando que suas aplicações influenciam diretamente no desenvolvimento do país e na qualidade de vida da população brasileira.

\section{Conclusões}

Jânio Quadros utilizava a política externa como ferramenta a serviço da resolução de problemas internos. Um dos principais gargalos que impediam o país de alcançar uma posição de destaque entre as grandes potências era seu modesto desenvolvimento científico e tecnológico. Entusiasmado com as conquistas espaciais recentes dos EUA e URSS e sendo fortemente aconselhado por um grupo de civis e militares brasileiros determinados a desenvolverem as tecnologias espaciais internamente, Jânio Quadros, em um período de seis meses, fez o que os seus antecessores não fizeram: articulou e executou a criação do primeiro órgão responsável por pesquisas e desenvolvimento da tecnologia espacial no Brasil, o GOCNAE.

Três foram os motivadores principais para a decisão de Jânio Quadros de impulsionar as atividades espaciais no Brasil: seu relacionamento pessoal com membros da SIB, que tinham acesso direto ao presidente; a visita do astronauta russo Yuri Gagarin ao Brasil, estimulada pelo próprio Jânio; e, principalmente, seu comprometimento com o progresso das ciências no Brasil, que ultrapassava, até mesmo, os condicionantes ideológicos da Guerra Fria.

Nada disso seria possível, contudo, sem a existência de um novo paradigma de política externa na gestão de Quadros. A constituição de uma política externa arrojada e pragmática, que se amparava na desideologização, no neutralismo, ou seja, no estabelecimento de parcerias sem preconceitos ideológicos, foi a outorga necessária para se levar adiante o plano de iniciar as atividades espaciais no Brasil de forma institucionalizada. A PEI foi o início de um processo de afastamento do americanismo puro, um paradigma de política externa que vinha desde o início da República, que inibia a tomada de decisões mais autônomas do Brasil que não se coadunassem com os interesses dos EUA.

Quadros, em seu artigo publicado na revista Foreign Affairs, deixou clara a sua insatisfação com o jogo que as grandes potências ainda faziam com o Brasil. A nova política externa era uma tentativa de diminuir a forte dependência brasileira, 
para, assim, corrigir os inúmeros desequilíbrios socioeconômicos existentes no Brasil. Quadros acreditava que alçar o Brasil à condição de detentor de tecnologias espaciais traria desenvolvimento econômico e destaque internacional para o país.

Apesar da curta duração de sua administração, Jânio Quadros será permanentemente relacionado à inauguração de uma nova vertente de política externa, a PEI, que ampliou as possibilidades de atuação internacional do país e permitiu o desenvolvimento de uma agenda doméstica relativamente livre dos condicionamentos externos. No ramo espacial, a figura de Quadros também se associa à criação da primeira instituição dedicada às atividades espaciais. A sua influência direta no desenvolvimento do GOCNAE permite que se atribua ao Brasil o título de um dos primeiros países em desenvolvimento a investir em pesquisas de tecnologias exclusivamente espaciais. Nessa época, apenas China e Índia estavam no mesmo estágio.

Não obstante o grande impulso dado pelo país com a institucionalização do GOCNAE - que, dez anos depois, se tornou INPE, uma das mais dedicadas e conceituadas instituições científicas brasileiras da atualidade -, o programa espacial brasileiro enfrentou um lento processo de desenvolvimento. Com a transferência de tecnologia da URSS, indianos e chineses souberam desenvolver seus programas espaciais em um curto período. Em 1965, a China já lançava seu primeiro foguete e, cinco anos depois, já conseguia colocar um satélite em órbita (RODRIGUES, 2015, p. 1).

Enquanto isso, no Brasil, o foco girava em torno de adquirir a tecnologia de satélites e foguetes a partir de projetos ainda pouco ambiciosos e com auxílio internacional, em especial da França, parceira na elaboração da Missão Espacial Completa Brasileira (MECB), estabelecida em 1979, e também dos EUA, através do projeto SONDA, de desenvolvimento de foguetes de pequeno porte para serem utilizados em experimentos na atmosfera (CARVALHO, 2011, p. 18; RODRIGUES, 2015, p. 1; COSTA FILHO, 2002, p. 78).

Nesse início, o caráter essencialmente militar dos projetos foi responsável pelo excesso de lentidão no andamento das atividades e pelo afastamento das parcerias internacionais, que temiam o uso não pacífico das tecnologias de mísseis. Foi somente em 1994, com a criação da Agência Espacial Brasileira (AEB), que o programa espacial passou a ter uma finalidade civil, o que, no entanto, não afastou a suspeita de alguns países quanto ao componente militar de suas atividades (SANTOS, 1999, p. 118; RODRIGUES, 2015, p. 2). 
Contudo, enquanto os programas espaciais de países emergentes como China, Índia e Argentina vêm avançando de forma acelerada, o programa brasileiro perde o destaque que obteve por ter sido um dos mais antigos e completos. Hoje, ele caminha em passos lentos, apesar de anos de dedicação de diversos cientistas e técnicos. Entre as justificativas para a lentidão no progresso tecnologia espacial no Brasil, estão o orçamento limitado destinado aos projetos e pesquisas; os embargos internacionais; as dificuldades operacionais e a cooperação internacional verticalizada que não foi acompanhada de resultados na evolução do Programa Espacial (ROLLEMBERG, 2009, p. 4, 27, 34-35).

\section{Referências}

ÁLVARES, Vera Cíntia. Reflexões sobre o surgimento da "Política Externa Independente” na gestão de Jânio Quadros. In: Ensaios de História Diplomática do Brasil (1930-1986) - Cadernos do IPRI n. 2. Brasília: Fundação Alexandre de Gusmão, 1989.

BRASIL. Decreto n. 51.133 de 3 de Agosto de 1961. Cria o Grupo da Comissão Nacional de Atividades Espaciais e dá outras providências. Disponível em: < http://www2. camara.leg.br/legin/fed/decret/1960-1969/decreto-51133-3-agosto-1961-390741publicacaooriginal-1-pe.html > . Acesso em: 1 Nov 2016.

CARVALHO, Himilcon de Castro. Alternativas de financiamento e parcerias internacionais estratégicas no setor espacial. In: FREITAS, W. L. de. (coord.). Desafios do Programa Espacial Brasileiro. Brasília: Presidência da República - Secretaria de Assuntos Estratégicos, 2011. p. 17-40. Disponível em: < http://www.sae.gov.br/wp-content/ uploads/espacial_site.pdf >. Acesso em: 1 Nov 2016.

CERVO, Amado Luiz; BUENO, Clodoaldo. História da Política Exterior do Brasil. 3a ed. Brasília: Editora Universidade de Brasília, 2010.

CERVO, Amado Luiz. Eixos conceituais da política exterior do Brasil. In: Revista Brasileira de Política Internacional. V. 41, N. spe. Brasília, 1998. Disponível em: http://www. scielo.br/scielo.php?script = sci_arttext\&pid = S0034-73291998000300005 Acesso em: 01 Nov 2016.

COSTA FILHO, Edmilson. Política Espacial Brasileira: A política científica e tecnológica no setor aeroespacial brasileiro. Rio de Janeiro: Revan, 2002.

CORREIO DA MANHÃ. O céu é muito escuro e a Terra azulada. Rio de Janeiro: 13.04.1961. Primeira página. 1961a. Disponível em: < http://memoria.bn.br/hdb/uf.aspx > . Acesso em: 04 Nov 2016.

CORREIO DA MANHÃ. A notícia dia a dia. Rio de Janeiro: 16.07.1961. 1961b. Disponível em: < http://memoria.bn.br/hdb/uf.aspx > . Acesso em: 04 Nov 2016. 
CORREIO DA MANHÃ. A notícia dia a dia. Rio de Janeiro: 18.07.1961. 1961c. Disponível em: < http://memoria.bn.br/hdb/uf.aspx > . Acesso em: 04 Nov 2016.

CORREIO DA MANHÃ. Gagarin recebe comenda do Mérito Aeronáutico. Rio de Janeiro: 3.08.1961. 1961d. Disponível em: < http://memoria.bn.br/hdb/uf.aspx > Acesso em: 04 Nov 2016.

CORREIO DA MANHÃ. Gagarin convidado a visitar SP. Rio de Janeiro: 22.07.1961. 1961e. Disponível em: < http://memoria.bn.br/hdb/uf.aspx > . Acesso em: 04 Nov 2016.

DA ROSA, Aldo Weber Vieira. Entrevista concedida ao ex-diretor do SindCT (Sindicato dos Servidores de Ciência e Tecnologia), em 2007. Disponível em: http://www. sindct.org.br/?q = node/29. Acesso em 04 Nov 2016.

ESCADA, Paulo Augusto Sobral. Origem, institucionalização e desenvolvimento das atividades espaciais brasileiras (1940-1980). 2005. 129f. Dissertação (Mestrado em Ciência Política) - Instituto de Filosofia e Ciências Humanas (IFCH), Universidade Estadual de Campinas. Campinas, 2005.

ESTADO DE SÃO PAULO. Astronauta soviético enviado ao espaço regressa depois de circundar a Terra: a humanidade entra na Idade Cósmica. São Paulo: 13.04.1961. Disponível em: < http://memoria.bn.br/hdb/uf.aspx > . Acesso em: 03 Nov 2016. FOLHA DE SÃO PAULO. Gagarin recebe convite para vir a São Paulo. São Paulo: 21.07.1961. 1961a. Disponível em: < http://acervo.folha.uol.com.br/fsp/1961/07/21/2//4487549 > . Acesso em: 03 Nov 2016.

FOLHA DE SÃO PAULO. Gagarin, "honrado" com o convite, chega ao Brasil depois de amanhã. São Paulo: 27.07.1961. Primeiro Caderno. 1961b. Disponível em: < http:// acervo.folha.uol.com.br/fsp/1961/07/27/2//4488014 > . Acesso em: 03 Nov 2016.

FOLHA DE SÃO PAULO. Esperado amanhã no Rio o cosmonauta Gagarin. São Paulo: 28.07.1961. 1961c. Disponível em: < http://acervo.folha.uol.com.br/ fsp/1961/07/28/2//4488087 > . Acesso em: 03 Nov 2016.

FOLHA DE SÃO PAULO. Gagarin fez conferência, almoçou com jornalistas e falou com governador. São Paulo: 2.08.1961. 1961d. Disponível em: < http://acervo.folha.uol. com.br/fsp/1961/08/02/2//4488563 > . Acesso em: 03 Nov 2016.

FOLHA DE SÃO PAULO. Entusiasmo à chegada de Gagarin a Brasília; violência contra a imprensa. São Paulo: 30.07.1961, p. 13. 1961e. Disponível em: < http://acervo. folha.uol.com.br/fsp/1961/07/30/2//4488183 > . Acesso em: 03 Nov 2016.

FRANCO, Álvaro da Costa (Org.). Documentos da Política Externa Independente. Brasília: Fundação Alexandre de Gusmão, 2007.

GATTO, Rubens Cruz. A inovação e o setor público no Brasil: o papel do Estado no desenvolvimento das atividades espaciais no INPE. 2010. 47f. Trabalho de Conclusão de Curso (MBA em Gestão Estratégica da Ciência e Tecnologia em Instituições Públicas de Pesquisa) - Fundação Getúlio Vargas. São José dos Campos: 2010. 
GOUVEIA, Adalton. Esboço histórico da pesquisa espacial no Brasil. Instituto Nacional de Pesquisas Espaciais - INPE. São José dos Campos: 2003.

JORNAL DO BRASIL. Gagarin chega sábado ao Rio, anuncia Arinos em Brasília. São Paulo: 27.07.1961. 1961a. Disponível em: < http://memoria.bn.br/hdb/uf.aspx > . Acesso em: 03 Nov 2016.

JORNAL DO BRASIL. Gagarin chega ao Brasil com honras militares e tumulto. Rio de Janeiro: 30.07.1961. Primeiro Caderno, p. 04. 1961b. Disponível em: < http://memoria.bn.br/hdb/uf.aspx > . Acesso em: 03 Nov 2016.

JORNAL DO BRASIL. Gagarin diz que o Brasil pode contribuir nas pesquisas astronáuticas. Rio de Janeiro: 2.08.1961. 1961c. Disponível em: < http://memoria.bn.br/hdb/ uf.aspx > . Acesso em: 03 Nov 2016.

JORNAL DO BRASIL. Toma posse grupo que vai estudar o espaço e começa soltando foguetes. Rio de Janeiro: 23.01.1962. Disponível em: < http://memoria.bn.br/hdb/ uf.aspx > . Acesso em: 04 Nov 2016.

QUADROS, Jânio. Nova Política Externa do Brasil. In: Revista Brasileira de Política Internacional. Ano IV, n. 16, dez 1961.

RODRIGUES, Alexandre. Qual é o problema do programa espacial brasileiro? Galileu. 07 Jan 2015. Disponível em: < http://revistagalileu.globo.com/Revista/noticia/2015/01/ nos-temos-um-problema.html > . Acesso em: 1 Nov 2016.

ROllemberG, Rodrigo. Cenário e perspectivas da Política Espacial Brasileira. In: ROLLEMBERG, Rodrigo (relator); VELOSO, Elizabeth Machado (coord.). A Política Espacial Brasileira. Brasília: Câmara dos Deputados, 2009. Série Caderno de Altos Estudos N. 7. p. 19-84. Disponível em: < http://www2.camara.leg.br/a-camara/ altosestudos/arquivos/politica-espacial/a-politica-espacial-brasileira > . Acesso em: 1 Nov 2016.

SANTOS, Reginaldo. O Programa Nacional de Atividades Espaciais frente aos embargos tecnológicos. Parcerias Estratégicas. Vol. 4, N. 07, CGEE/MCT, Outubro/1999, p. 115-128. Disponível em: < http://www.cgee.org.br/arquivos/pe_07.pdf > . Acesso em: 1 Nov 2016.

SANTOS, Paulo Marques dos. Instituto Astronômico e Geofísico da USP: memória sobre a sua formação e evolução. São Paulo: Editora USP, 2005.

SATO, Eiiti. Almirante Álvaro Alberto: a busca do desenvolvimento científico e tecnológico nacional. In: PIMENTEL, José Vicente de Sá. Pensamento Diplomático Brasileiro: formuladores e agentes da política externa (1750-1964). Vol. III, Brasília, Funag, 2013, p. 801-842.

ÚlTiMA HORA. Gagarin sábado no Rio a convite de Jânio. P. 04. Rio de Janeiro: 27.07.1961. 1961a. Disponível em: < http://memoria.bn.br/hdb/uf.aspx > . Acesso em: 03 Nov 2016. 
ÚLTIMA HORA. Jânio estuda (com cuidado) foguetes ianques no Brasil. Rio de Janeiro: 4.08.1961. 1961b. Disponível em: < http://memoria.bn.br/hdb/uf.aspx > . Acesso em: 04 Nov 2016.

ÚlTIMA HORA. Pesquisas espaciais. Rio de Janeiro: 19.02.1961. 1961c. Disponível em: < http://memoria.bn.br/hdb/uf.aspx > . Acesso em: 03 Nov 2016.

VISENTINI, Paulo Fagundes. Relações Exteriores do Brasil II (1930-1964): o nacionalismo, da Era Vargas à Política Externa Independente. Coleção Relações Internacionais. 2a ed. Petrópolis, RJ: Editora Vozes, 2009.

WROBEL, Paulo S. Aspectos da Política Externa Independente: a questão do desarmamento e o caso de Cuba. Estudos Históricos. Rio de Janeiro, Vol. 6, n. 12, 1993, p. 191-209. 


\title{
A geopolítica das terras raras ${ }^{1}$
}

\author{
The Geopolitics of rare earths
}

DOI: $10.21530 /$ ci.v12n2.2017.634

Filipe Reis Melo²

\section{Resumo}

Variações de oferta e dificuldades de acesso a determinados produtos estratégicos podem provocar mudanças na geopolítica internacional. Os choques do petróleo ocorridos na década de 1970 são, talvez, os exemplos mais conhecidos de como a reconfiguração do poder entre os países pode ser redesenhada em função de quem detém determinado produto estratégico. Um conjunto de 17 metais, conhecidos como terras raras, que possui propriedades químicas únicas, está no centro de uma tensão comercial internacional desde que a China, que exporta cerca de $95 \%$ do mercado mundial de terras raras, passou a restringir suas exportações a partir de meados de 2000. Este artigo investiga as motivações políticas e econômicas que estiveram por trás do embate na Organização Mundial do Comércio (OMC) entre a China, de um lado, e os Estados Unidos, a União Europeia e o Japão, de outro, que denunciaram a China em 2012 por impor restrições à exportação de terras raras, e analisa como o Brasil poderia aproveitar o seu potencial como produtor de terras raras para fortalecer sua posição no cenário internacional. Conclui-se que o diferendo na OMC foi apenas o primeiro capítulo de uma história de tensões internacionais que estão por vir no cenário internacional.

Palavras-chave: Terras raras; OMC; China; Brasil

\begin{abstract}
Instability in supply and difficulties in reaching some strategic products can lead to changes in global geopolitics. The 1970s petroleum shock are, perhaps, the most recent examples of how the power between countries can be redefined by whom owns a particular strategic product. A set of seventeen metals known as rare earths, which has special chemical properties, is the core of international trade tension since China, which exports about $95 \%$ of the global rare earth market, began to restrict its exports from 2000s. This paper is about the political and

1 Pesquisa financiada pelo Edital MCTI/CNPq/MEC/CAPES nº 43/2013

2 Departamento de Relações Internacionais da Universidade Estadual da Paraíba, João Pessoa/PB, Brasil. E-mail: freismelo@yahoo.com

Artigo submetido em 12/02/2017 e aprovado em 03/05/2017.
\end{abstract}


economic motivations behind the dispute in the World Trade Organization (WTO) between on the one hand China, and on the other hand the United States, the European Union and Japan, which denounced China in 2012 by imposing restrictions on rare earths exports and examines how Brazil could seize the opportunity of its potential as a rare earth producer to strengthen its position on the international system. It is concluded that the WTO dispute was only the first chapter of a history of international tensions that are to come on the international stage.

Keywords: Rare Earth; WTO; China; Brazil

A recente oferta apertada de energia, alimentos e muitas matérias-primas também provocou uma preocupação mais geral - que possamos passar de uma era de abundantes suprimentos para uma de constante escassez. [Governo dos Estados Unidos/Administração Nixon, 1974. Critical Imported Materials: Study of Ad Hoc Group Established by NSSM 197/CIEPSM 33 (BUIJS; SIEVERS, 2011)]. ${ }^{3}$

O Oriente Médio tem seu petróleo, a China tem terras raras: os depósitos de terras raras da China representam $80 \%$ das reservas globais identificadas, podese comparar o status dessas reservas com o do petróleo no Oriente Médio: é de importância estratégica extremamente importante; devemos ter certeza de lidar com a questão das terras raras corretamente e aproveitar ao máximo a vantagem do nosso país em recursos de terras raras [Discurso de Deng Xiaoping em 1992 (KIGGINS, 2015)]. ${ }^{4}$

\section{Introdução}

As variações de oferta e as dificuldades de acesso a determinados produtos estratégicos para a economia mundial podem provocar mudanças na geopolítica internacional. Os dois choques do petróleo ocorridos na década de 1970 são, talvez, os exemplos mais conhecidos de como a reconfiguração do poder pode ser redesenhada em função de quem detém determinado recurso natural estratégico.

3 The recent tight supply situation for energy, food and many raw materials has also prompted a more general concern-that we may be passing from an era of abundant supplies into one of constant shortages. [US Government (Nixon Administration, 1974). Critical Imported Materials: Study of Ad Hoc Group Established by NSSM 197/CIEPSM 33 (BUIJS; SIEVERS, 2011)].

4 The Middle East has its oil, China has rare earth: China's rare earth deposits account for 80 percent of identified global reserves, you can compare the status of these reserves to that of oil in the Middle East: it is of extremely important strategic significance; we must be sure to handle the rare earth issue properly and make the fullest use of our country's advantage in rare earth resources. [Discurso de Deng Xiaoping em 1992 (KIGGINS, 2015)]. 
Na primeira década do século XXI, o mercado internacional de matériasprimas, commodities e minerais experimentou um aumento da demanda mundial em virtude da aceleração do crescimento econômico mundial, em especial dos países em desenvolvimento de renda média, especialmente a China, a Índia e, em menor medida, o Brasil. Após a crise de 2008, o crescimento da economia mundial foi reduzido, mas não comprimiu na mesma proporção a demanda por matérias-primas, a exemplo das terras raras.

Os recursos naturais estão distribuídos de forma desigual ao redor da Terra, assim como a tecnologia disponível e a capacidade de investimento não são iguais em qualquer parte do globo. Alguns recursos são encontrados em poucas regiões do mundo e a sua exploração e exportação dependem de poucos países. Quando metade ou mais da produção mundial de determinada matéria-prima está concentrada num único país, os países importadores tornam-se dependentes desse produtor, que passa a deter grande poder de influência sobre os preços e sobre as quantidades comercializadas mundialmente. Essa foi a situação que ocorreu entre o fim da década de 1990 e a década de 2000, com relação à produção e exportação de terras raras, tendo a China o monopólio mundial desse mercado.

Este artigo busca fazer uma primeira reflexão acerca da tensão internacional pelo acesso às terras raras, que surgiu a partir da segunda década dos anos 2000. A primeira parte faz um rápido apanhado acerca das metodologias e das variáveis utilizadas para estabelecer o grau de criticidade de uma matéria-prima. A segunda parte situa o leitor acerca da importância das terras raras para as indústrias civil e militar. Em seguida, expõe o panorama do mercado internacional de terras raras, identificando os países detentores das principais reservas desses minerais. Procura demonstrar a preocupação dos principais países importadores de terras raras e como a tensão gerada por garantir o acesso às terras raras entre os Estados Unidos, a União Europeia e o Japão de um lado, e a China de outro, chegou à Organização Mundial do Comércio (OMC). Ao final, o artigo aponta as principais medidas tomadas pela comunidade acadêmica e pelo governo brasileiro e apresenta as considerações finais.

Os riscos ligados às dificuldades de acesso a determinados recursos estratégicos, na maioria das vezes, estão ligados a situações como a instabilidade política nos países exportadores, a nacionalização de minas e de empresas mineradoras, questões ligadas à proteção ambiental, à adoção de política de desenvolvimento nacional que busque priorizar a utilização das matérias-primas nos países produtores ou à ocorrência de desastres ambientais. Em contraponto a situações dessa natureza, 
os países importadores podem levar a cabo políticas de armazenamento de longo prazo, estabelecer contratos de compra e venda de longo prazo, desenvolver pesquisas para obter maiores taxas de reciclagem e/ou de substituição de matériasprimas ou ainda buscar aumentar a eficiência produtiva.

Alguns trabalhos de pesquisa têm buscado avaliar a possibilidade de redução do fluxo de suprimento de determinadas matérias-primas, bem como o impacto econômico que choques de oferta podem provocar (MAYER; GLEICH, 2015; NASSAR et al., 2012; BUIJS; SIEVERS, 2011; BUIJS; SIEVERS; TERCERO ESPINOZA; 2012; GRAEDEL et al., 2012; HATCH, 2011). O conceito de criticidade de matéria-prima apareceu pela primeira vez em 1939 (MAYER; GLEICH, 2015), no documento Material Stock Piling Act, cuja intenção era regular o acesso a certas matériasprimas relevantes para a indústria militar.

De acordo com Buijs e Sievers (2011), uma avaliação não adequada dos riscos pode resultar numa reação desproporcional. Segundo Buijs, Sievers e Tercero Espinoza (2012), o termo "matéria-prima crítica" significa que aquela matériaprima combina duas características: grande importância econômica e risco de quebra no seu fornecimento. Está claro que estabelecer a criticidade de uma matéria-prima é um conceito relativo, pois traz consigo certa imprecisão, já que não parecem ser facilmente mensuráveis a importância econômica e o risco de quebra de fornecimento. Tampouco há um consenso acerca de quais indicadores poderiam ser utilizados satisfatoriamente. O grau de dependência de um país em relação a fornecedores estrangeiros pode ser um dos indicadores aceitáveis. Hatch (2011) sugere como um desses indicadores a combinação de projeção de oferta e de demanda. Não é simples a mensuração dessas variáveis, ainda mais porque o contexto de cada mercado pode mudar ao longo do tempo, variando em função de quais países são exportadores e importadores. A inovação tecnológica tanto pode prescindir de determinada matéria-prima antes utilizada, contribuindo para a redução de sua demanda, como pode provocar o aumento da procura por determinada matéria-prima e assim suscitar um rápido aumento nos seus preços internacionais, principalmente quando se trata de mercados cuja oferta é inelástica e responde lentamente aos estímulos de demanda. Fatores como o curto, o médio e o longo prazo também são fatores importantes para uma melhor avaliação acerca dos ciclos de oferta. Todos esses fatores precisam ser levados em conta ao se tentar avaliar o nível de vulnerabilidade de países ou de empresas que dependem da importação de certo produto. O Gráfico 1 traz um esquema utilizado pela Comissão Europeia (EUROPEAN COMMISSION, 2010) que busca sistematizar uma forma 
de classificar uma matéria-prima como crítica. De acordo com esse parâmetro, uma matéria-prima só poderia ser assim classificada se estivesse no quadrante superior direito, ou seja, se a matéria-prima apresentar concomitantemente alta "Importância Econômica" e "Risco de Quebra de Oferta".

Gráfico 1: Representação do grau de "criticidade" de um bem a partir dos indicadores "Importância Econômica" e "Risco de Quebra de Oferta" (incluídas as taxas de substituição e de reciclagem)

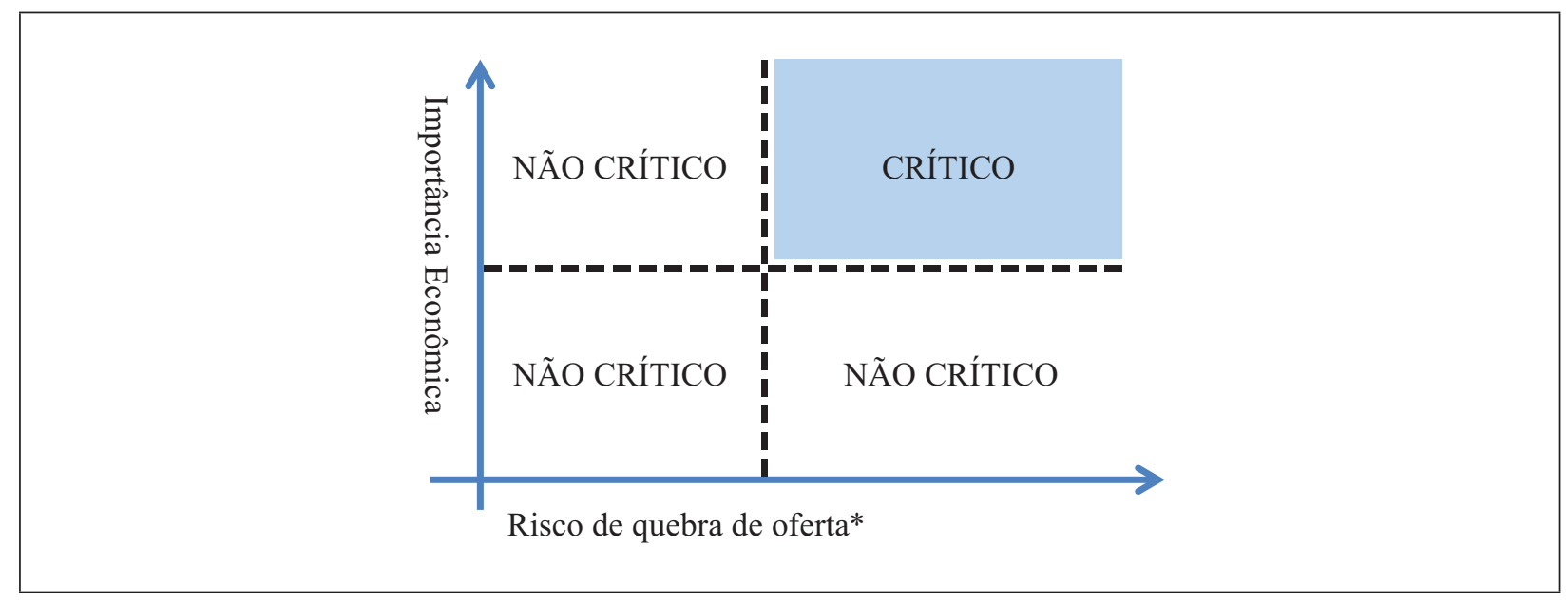

* Inclui taxa de substituição e de reciclagem.

Fonte: BUIJS; SIEVERS, 2011.

O tema das restrições às exportações nunca ganhou importância nas rodadas do Acordo Geral sobre Tarifas e Comércio (GATT) nem nas da OMC. Tradicionalmente, os temas das rodadas sempre estavam ligados ao protecionismo, às barreiras às importações, aos subsídios, ao dumping, ao comércio desleal e aos direitos de propriedade intelectual. Ou seja, o embate no GATT e na OMC sempre se dava no sentido de que países sentiam-se prejudicados por não poderem exportar mais ou por considerarem-se vítimas de uma concorrência desleal que punha em risco algum setor econômico. Daí os temas ligados à defesa comercial, aos subsídios, às normas de salvaguardas e às medidas compensatórias tomarem grande parte das discussões no âmbito da OMC. Portanto, o contencioso na OMC que teve início em 2012, sobre as restrições às exportações de terras raras chinesas, pode ser considerado paradigmático porque inverte a lógica habitual das disputas: agora o país importador exige que o país exportador lhe venda.

Ao se observar o número das disputas registradas pela OMC no seu portal oficial (WORLD TRADE ORGANIZATION, [sem data]), desde a sua fundação em janeiro de 1995 até 8 de março de 2017, constata-se que houve 524 disputas. 
A grande maioria delas dizia respeito à concorrência desleal e a alguma forma de protecionismo. Dessas 524 demandas, apenas 9 diziam respeito a restrições à exportação ${ }^{5}$. Dados da Organização para Cooperação e o Desenvolvimento Econômico (OCDE) demonstram que, a partir do início da década de 2000, o número de países que tomaram medidas para restringir suas exportações aumentou. Entre 1997 e 2002, a OMC registrou 39 casos (entre os 100 países membros), enquanto que, entre 2003 e 2009, foram registrados 65 (entre os 128 países membros) (KIM, 2010). Os produtos mais afetados pelas restrições foram minerais, metais, pedras preciosas, produtos agrícolas, florestais e de pesca. A maioria dos países que faz uso dessas restrições são países em desenvolvimento. Diferentes razões levam os países a adotarem restrições às exportações. As mais frequentes são as ligadas à segurança estratégica (para garantir o acesso a determinado insumo), segurança nacional e/ou internacional (restrições de venda de armas e produtos correlatos a determinados países), ao controle da inflação, ao aumento da arrecadação tributária, à segurança alimentar e à proteção ambiental. Talvez o caso mais conhecido de proibição de exportação com fins estratégicos seja o dos Estados Unidos que, em 1973, em plena crise do choque do petróleo, proibiram a exportação de petróleo.

\section{Terras Raras, minerais singulares}

As terras raras são um conjunto de 17 elementos químicos da tabela periódica compreendidos entre os números atômicos 57 e 71 (Lantânio -La-, Cério -Ce-, Praseodímio -Pr-, Neodímio -Nd-, Promécio -Pm-, Samário -Sm-, Európio -Eu-, Gadolínio -Gd-, Térbio -Tb-, Disprósio -Dy-, Hólmio -Ho-, Érbio -Er-, Túlio Tm-, Itérbio -Yb- e Lutécio -Lu), além dos números atômicos 21, Escândio -Sc-, e o 39, o Ítrio -Y. A sua localização na Tabela Periódica dos Elementos aparece em destaque na Figura 1.

5 As duas primeiras foram interpostas pela União Europeia por restrições à exportação de couro contra o Paquistão, em 1997, (DS 107, 07/11/1997), e contra a Índia, em 1998 (DS 120, 11/03/1998). A partir de 2009, todas as demandas foram contra a China. Três casos por restrições à exportação de algumas matérias-primas, reclamadas pelos Estados Unidos e pela União Europeia (DS 394 e DS 395, ambos em 23/06/2009) e pelo México (DS 398, 21/08/2009). Em 2012, os Estados Unidos, o Japão e a União Europeia denunciaram a China por restrições à exportação de terras raras (DS 431, DS 432 e DS 433, 13/03/2012). Finalmente, em 2016, a União Europeia denunciou a China por restrição à exportação de algumas matérias-primas (DS 509, 23/11/2016). 
Figura 1: Tabela Periódica: terras raras

\begin{tabular}{|c|c|c|c|c|c|c|c|c|c|c|c|c|c|}
\hline \multicolumn{13}{|l|}{$\mathrm{H}$} & \multirow{2}{*}{$\frac{\mathrm{He}}{\mathrm{Ne}}$} \\
\hline Li & $\mathrm{Be}$ & & & & & & & & & $\mathrm{N}$ & 0 & $F$ & \\
\hline $\mathrm{Na}$ & $\mathrm{Mg}$ & & & & & & & & & $P$ & $S$ & $\mathrm{Cl}$ & $\mathrm{Ar}$ \\
\hline K & $\mathrm{Ca}$ & Sc & Ti & V & $\mathrm{Cr}$ & $\mathrm{Mn}$ & $\mathrm{Fe}$ & $\mathrm{Cc}$ & $N$ & As & $\mathrm{Se}$ & $\mathrm{Br}$ & $\mathrm{Kr}$ \\
\hline $\mathrm{Rb}$ & $\mathrm{Sr}$ & Y & $\mathrm{Zr}$ & $\mathrm{Nb}$ & Mo & Tc & Ru & $\mathrm{Rr}$ & $P$ & $\mathrm{Sb}$ & Te & 1 & Xe \\
\hline Cs & $\mathrm{Ba}$ & La-Lu & $\mathrm{Hf}$ & $\mathrm{Ta}$ & W & $\operatorname{Re}$ & Os & Ir & P & $\mathrm{Bi}$ & Po & At & $\mathrm{Rn}$ \\
\hline $\mathrm{Fr}$ & $\mathrm{Ra}$ & Ac-Lr & $\mathrm{Rf}$ & $\mathrm{Db}$ & $\mathrm{Sg}$ & $\mathrm{Bh}$ & $\mathrm{Hs}$ & $M$ & D & Uup & LV & Uus & Uuo \\
\hline & & Lanta & ídeo & & & & & & & & & & \\
\hline & & La & $\mathrm{Ce}$ & $\mathrm{Pr}$ & $\mathrm{Nd}$ & $\mathrm{Pm}$ & $\mathrm{Sm}$ & Ec & G & $\mathrm{Tm}$ & $\mathrm{Yb}$ & Lu & \\
\hline
\end{tabular}

Fonte: elaboração própria com base em TABELA, 2017.

Apesar do nome, esses 17 elementos químicos nem são terras, nem são raros, quando comparados a outros elementos químicos mais escassos na natureza, a exemplo da prata. O seu nome deriva da dificuldade tecnológica e do alto custo para extraí-los, separá-los e purificá-los para o uso em escala industrial. Normalmente, as terras raras são divididas em dois grupos: leves e pesadas, e sua utilização mais detalhada está descrita no Quadro 1.

As terras raras estão presentes em mais de duzentas e cinquenta substâncias minerais, mas só em algumas dessas substâncias ocorrem terras raras em concentração suficiente para justificar seu aproveitamento (CÂMARA DOS DEPUTADOS, 2014). As principais substâncias minerais das quais se pode extrair terras raras em quantidades industriais são monazita, bastnaesita, xenotímio e certas argilas. Essas argilas, exploradas apenas na China, e o xenotímio são as principais fontes de terras raras pesadas. Já a monazita e a bastnaesita são importantes fontes de terras raras leves (CÂMARA DOS DEPUTADOS, 2014).

Segundo Martins e Isolani (2005), a totalidade das terras raras só passou a ser conhecida no início do século XX. O uso industrial teve início com a utilização na fabricação de camisas para lampiões. A partir de então, o uso industrial das terras raras tem aumentado com o descobrimento de novos usos, a exemplo das telas de LCD, das baterias de equipamentos eletrônicos e do crescimento das energias renováveis. Prevê-se que a demanda mundial desse tipo de produto aumente com o desenvolvimento de novas tecnologias. Apesar de esses minerais 
representarem uma percentagem muito baixa da composição do produto final, sua utilização é essencial para o desenvolvimento de produtos tecnologicamente sofisticados e, portanto, as terras raras tornaram-se uma matéria-prima estratégica no desenvolvimento de produtos para as áreas militar e civil.

A demanda por esse tipo de produto se explica pelo aumento de sua aplicação em novos processos de produção industrial e por possuir propriedades químicas magnéticas e fluorescentes únicas. O prolongamento do tempo de vida útil das baterias, bem como a capacidade de torná-las menores e mais leves, dependem essencialmente da utilização das terras raras. A indústria das energias renováveis, a exemplo da energia eólica, depende da aplicação das terras raras, especialmente no que diz respeito ao acúmulo e à conservação da energia gerada. Esses metais são, portanto, utilizados na produção de energias renováveis, no processamento de petróleo, em aplicações metalúrgicas, na fabricação de laser e na fabricação de produtos de tecnologia de ponta como: catalisadores, iluminação de displays, telas de computadores, telas de plasma, LED's, tablets, smartphones, geradores eólicos, veículos híbridos, fibras óticas, motores de aviões, componentes de cápsulas espaciais e satélites, baterias recarregáveis, ímãs de alto rendimento, supercondutores, luminóforos, equipamentos de comunicação à distância, memórias de computadores e de telefones celulares.

No que se refere a equipamento militar, as ligas metálicas com terras raras são fundamentais para o funcionamento de diversos armamentos e equipamentos. As munições de precisão perdem a sua eficiência de seu trajeto rumo ao alvo na falta de terras raras, ou seja, há uma perda importante na capacidade de precisão e, consequentemente, poderia haver um aumento no índice de baixas civis (KIGGINS, 2015). O Samário (Sm) e o Neodímio (Nd) são as terras raras mais utilizadas em equipamentos militares. São essenciais para a produção de sistemas de radar, ímãs que suportam altas temperaturas, utilizados em mísseis teleguiados, “bombas de precisão”, turbinas eólicas e caças (HUMPHRIES, 2012). Talvez seja por esse aspecto, o da possibilidade de redução do suprimento de terras raras para viabilizar a eficiência dos equipamentos militares, que os países tenham a percepção de insegurança, principalmente aqueles que possuem os equipamentos militares tecnologicamente mais avançados.

As terras raras possuem ainda uma vasta aplicação biológica, como em sondas espectroscópicas no estudo de biomoléculas, traçadores biológicos para acompanhar o caminho percorrido pelos medicamentos em pessoas e em animais; marcadores em imunologia, agentes de contraste em diagnóstico não invasivo de 
patologias em tecidos por imagem de ressonância magnética nuclear (MARTINS; ISOLANI, 2005).

No Quadro 1, pode-se observar um resumo das principais utilizações industriais das terras raras.

Quadro 1: Terras raras e suas aplicações.

\begin{tabular}{|l|c|l|}
\hline \multicolumn{1}{|c|}{ Terra Rara } & Tipo & \\
\hline Escândio & Leve & Aeronáutica, espacial, óptica \\
\hline Lantânio & Leve & Supercondutores, laser, motores híbridos, ligas metálicas, baterias \\
\hline Cério & Leve & $\begin{array}{l}\text { Catalizadores para carro e para refino de petróleo, ligas metálicas, telas } \\
\text { de cristal líquido, óptica }\end{array}$ \\
\hline Praseodímio & Leve & Ímãs, aeronáutica, espacial \\
\hline Neodímio & Leve & $\begin{array}{l}\text { Ímãs de alta resistência, catalizadores para carro e para refino de petróleo, } \\
\text { discos rígidos para laptops, fones de ouvido, ímãs, motores híbridos }\end{array}$ \\
\hline Promécio & Leve & Iluminação sem elevação de temperatura, espacial, radiologia \\
\hline Samário & Leve & Supercondutores, óptica, ímãs, eletrônica \\
\hline Európio & Leve & $\begin{array}{l}\text { Supercondutores, nuclear, tubos fluorescentes, cor vermelha para } \\
\text { televisão e telas de computadores }\end{array}$ \\
\hline Ítrio & Pesado & $\begin{array}{l}\text { Miras a laser, supercondutores, cor vermelha de lâmpadas fluorescentes, } \\
\text { cerâmicas agentes de ligas metálicas }\end{array}$ \\
\hline Gadolínio & Pesado & $\begin{array}{l}\text { Nuclear, radares, supercondutores, iluminação fosforescente, sistema de } \\
\text { guia de mísseis, ímãs }\end{array}$ \\
\hline Térbio & Pesado & Laser, iluminação fosforescente, lâmpadas de baixo consumo, ímãs \\
\hline Disprósio & Pesado & Nuclear, aeronáutica, ímãs de alta resistência, motores híbridos \\
\hline Hólmio & Pesado & $\begin{array}{l}\text { Laser, supercondutores, magnetismo, óculos especiais, corantes de vidro } \\
\text { laser }\end{array}$ \\
\hline Érbio & Pesado & Nuclear, metalurgia, energia fotovoltaica, fibra ótica \\
\hline Túlio & Pesado & Bateria nuclear, supercondutores, laser, radiologia \\
\hline Lutécio & Supercondutores, metalurgia inoxidável, ligas de aço \\
\hline
\end{tabular}

Fonte: elaboração própria a partir de dados de WEBER, 2012 e CÂMARA DOS DEPUTADOS, 2014.

Espera-se que a demanda por baterias recarregáveis de alto rendimento aumente em razão da evolução dos equipamentos elétricos e eletrônicos, seja para uso civil ou militar. Segundo o relatório da Comissão Europeia (EUROPEAN COMMISSION, 2010), a demanda de matérias-primas para a fabricação desse tipo de bateria deve crescer a uma taxa de $5 \%$ entre 2010 e 2020, o que, necessariamente, significa um aumento da demanda de terras raras. 


\section{Mercado mundial de terras raras}

Entre a década de 1980 e 2010, o mercado mundial de terras raras experimentou uma grande mudança. No final da década de 1980, a China vendia menos da metade das terras raras comercializadas no mundo. A partir de então, a sua fatia de mercado cresceu paulatinamente e, em duas décadas, a China passou a ter o monopólio desse mercado. Com custos de produção mais baixos do que os de outros países produtores, possivelmente por dispor de um custo de mão de obra mais barato e de uma legislação ambiental mais laxa, não foi difícil para a China tornar-se líder mundial do mercado de terras raras. Assim como o Brasil, os EUA deixaram de produzir terras raras entre as décadas de 1980 e 1990, e passaram a comprá-las da China, aparentemente pelo fato de ser mais barato importá-las do que produzi-las internamente. De acordo com Buijs, Sievers e Tercero Espinoza (2012, p. 204), “a principal razão para o fechamento da mina de Mountain Pass, na Califórnia, nos Estados Unidos, que nos anos 1970 representava $70 \%$ da oferta global de terras raras, foi que não pôde competir com os preços baixos da oferta chinesa" 6 . Em 2014, a China respondia por $95 \%$ das terras raras comercializadas no mundo (SOUSA FILHO; SERRA, 2014). Portanto, a China tinha e ainda tem o monopólio da venda desses minerais estratégicos.

Autores como Kiggins (2015) consideram que a China tem o objetivo de criar uma cadeia produtiva de terras raras, como parte de sua busca por manter o seu desenvolvimento econômico e, ao mesmo tempo, modernizar o seu aparato militar. Ainda segundo Kiggins (2015), a estratégia chinesa para o uso das terras raras, passa pelo desenvolvimento de seu setor industrial, em parte assentado no uso das terras raras para implementar novas tecnologias nas áreas de transporte, de comunicação e de defesa militar, e, finalmente, pelo exercício de sua influência sobre países dependentes da importação das terras raras.

Em 2010, o governo chinês tomou a iniciativa de racionalizar o setor ligado à produção de terras raras, reduzindo o número de empresas para ter um maior controle sobre a produção. Tal medida lhe permitiu aumentar a eficiência e a produtividade, bem como ter um maior controle sobre o impacto ambiental provocado pela exploração de terras raras (ZHANG, 2013 apud KIGGINS, 2015).

\footnotetext{
6 The main reason for the closure of the Mountain Pass mine in California in the United States, which in the 1970s provided 70 per cent of the global supply of rare earths, was that it could not compete anymore against such cheap Chinese supplies.
} 
A iniciativa de restringir as exportações de terras raras através da imposição de cotas de exportação, obrigação de obtenção de licenças especiais para exportação de terras raras, cobrança de impostos adicionais aos exportadores, entre outras iniciativas, foi um dos meios para atingir o seu objetivo. O conjunto dessas medidas provocou um aumento dos preços das terras raras exportadas pela China e, concomitantemente, uma diferença significativa entre o preço das terras raras vendidas dentro do mercado chinês e seu preço no mercado internacional. Segundo Kerinek e Kim (2010), os preços internacionais das terras raras chegaram a estar cerca de $20 \%$ a $40 \%$ acima dos preços praticados dentro do mercado chinês.

Por ser uma grande fornecedora desse produto, essas restrições, por um lado, causaram aumento dos preços internacionais e, por outro, "desvirtuaram a livre concorrência” ao obrigar as empresas localizadas fora da China a comprar terras raras por preços superiores aos comprados por empresas concorrentes localizadas na China. Essas medidas foram interpretadas por outros países como "subsídios artificiais" que beneficiavam as empresas chinesas.

Os preços internacionais das terras raras mantiveram-se relativamente estáveis durante a primeira metade da década de 2000. As medidas tomadas pelo governo chinês para restringir as exportações de terras raras, combinadas com a demanda crescente desses minerais, provocaram um rápido crescimento dos preços das terras raras no mercado internacional.

Quadro 2: Preços de alguns óxidos de terras raras - 2002 a 2013 (US\$/quilograma)

\begin{tabular}{|c|c|c|c|c|c|c|c|c|}
\hline \multirow{2}{*}{ Ano } & \multicolumn{7}{|c|}{ Te r r a s $\mathbf{R}$ a r a s } \\
\cline { 2 - 9 } & La & Ce & Nd & Pr & Sm & Dy & Eu & Tb \\
\hline $\mathbf{2 0 0 2}$ & 2,30 & 2,30 & 4,40 & 3,90 & 3,00 & 20,00 & 240,00 & 170,00 \\
$\mathbf{2 0 0 3}$ & 1,50 & 1,70 & 4,40 & 4,20 & 2,70 & 14,60 & 235,40 & 170,00 \\
$\mathbf{2 0 0 4}$ & 1,60 & 1,60 & 5,80 & 8,00 & 2,70 & 30,30 & 310,50 & 300,00 \\
$\mathbf{2 0 0 5}$ & 1,50 & 1,40 & 6,10 & 7,60 & 2,60 & 36,40 & 286,20 & 300,00 \\
$\mathbf{2 0 0 6}$ & 2,20 & 1,70 & 11,10 & 10,70 & 2,40 & 70,40 & 240,00 & 434,00 \\
$\mathbf{2 0 0 7}$ & 3,40 & 3,00 & 30,20 & 29,10 & 3,60 & 89,10 & 323,90 & 590,40 \\
$\mathbf{2 0 0 8}$ & 8,70 & 4,60 & 31,90 & 29,50 & 5,20 & 118,50 & 481,90 & 720,80 \\
$\mathbf{2 0 0 9}$ & 4,90 & 3,90 & 19,10 & 18,00 & 3,40 & 115,70 & 492,90 & 361,70 \\
$\mathbf{2 0 1 0}$ & 4,23 & 3,55 & 29,28 & 27,60 & 2,47 & 166,48 & 410,42 & 388,80 \\
$\mathbf{2 0 1 1}$ & 16,26 & 19,58 & 132,06 & 104,60 & 11,85 & 994,33 & $2.025,00$ & $1.596,82$ \\
$\mathbf{2 0 1 2}$ & 11,46 & 11,76 & 74,72 & 70,51 & 10,44 & 620,73 & $1.178,34$ & 949,04 \\
$\mathbf{2 0 1 3}$ & 5,40 & 5,40 & 51,20 & 73,10 & 5,60 & 313,60 & 741,00 & 584,30 \\
\hline
\end{tabular}

Fonte: Câmara dos Deputados, 2014. 
O preço das terras raras apresentou uma ligeira variação positiva entre 2002 e 2005. Entre 2005 e 2011, houve um rápido aumento dos preços até atingir o ápice em 2011. O Quadro 2 mostra o preço de alguns óxidos de terras raras entre 2002 e 2013. Entre 2002 e 2011, o preço do Disprósio (Dy) foi multiplicado por 49, o do Neodímio (Nd) foi multiplicado por 30 e o do Praseodímio (Pr) foi multiplicado por 26. A menor variação foi a do Samário $(\mathrm{Sm})$, cujo preço foi multiplicado por praticamente 4 .

Esse aumento dos preços das terras raras se deu em função de dois fatores combinados, um pelo lado da demanda e outro pelo lado da oferta: o aumento da demanda mundial e as restrições à exportação adotadas pelo governo chinês. Apesar de as terras raras terem valor unitário relativamente alto, o impacto no preço final dos produtos foi insignificante por causa da diminuta concentração desses minerais presente nos produtos acabados. A partir de 2012, quando a China iniciou o relaxamento nas medidas restritivas à exportação, os preços internacionais começaram a baixar.

Com a tecnologia disponível atualmente, é possível realizar a reciclagem de terras raras, mas a um custo que não é viável economicamente. No que se refere à substituição desses minérios por sucedâneos, todos apresentam um resultado aquém daquele que se obtém com as terras raras, o que torna os países importadores desses minerais dependentes dos produtores (EUROPEAN COMMISSION, 2010). Alguns países, como Japão, Alemanha e Estados Unidos, têm feito investimentos em pesquisas para descobrir substitutos das terras raras.

Quadro 3: Reservas globais de terras raras - 2010 (em \%).

\begin{tabular}{|l|c|}
\hline \multicolumn{1}{|c|}{ País } & \% do total \\
\hline Brasil & 37,01 \\
China & 25,33 \\
Comunidade dos Estados Independentes - CEI & 13,37 \\
Vietnã & 10,42 \\
Groelândia & 3,44 \\
Canadá & 2,90 \\
Austrália & 2,34 \\
Índia & 2,18 \\
Estados Unidos & 1,06 \\
África do Sul & 0,88 \\
Quênia & 0,68 \\
Quirguistão & 0,20 \\
Turquia & 0,09 \\
Malawi & 0,08 \\
\hline
\end{tabular}

Fonte: USGS apud CHEN, 2011, p. 3. 
O Quadro 3 apresenta os dados sobre as maiores reservas globais de terras raras. De acordo com o U.S. Geological Survey (USGS), as reservas seriam aqueles recursos de terras raras prontos para o uso industrial. O Brasil aparece em primeiro lugar, com 37,01\%, seguido da China, com 25,33\%, da Comunidade dos Estados Independentes (CEI), com 13,37\%, e, em quarto lugar, do Vietnã, com 10,42\% . Portanto, segundo esses dados, podemos intuir que o Brasil possui um enorme potencial para desenvolver uma cadeia produtiva de terras raras.

\section{Dependência dos principais importadores: EUA, Japão e União Europeia}

Países industrializados, em especial a União Europeia, os Estados Unidos e o Japão, têm-se mostrado preocupados com a possibilidade de não ter acesso a certas matérias-primas, incluídas as terras raras, cuja oferta, caso seja reduzida, pode ter importantes implicações para o funcionamento de suas economias.

O aumento da competição propiciado pela globalização tem incentivado alguns países a perseguir estratégias de desenvolvimento industrial e comercial através de medidas que reservam seus recursos para uso próprio. Nesse caso, as restrições às exportações buscam assegurar o fornecimento de insumos mais baratos à indústria nacional.

A Comissão Europeia divulgou um relatório, em fevereiro de 2011, intitulado Tackling the challenges in commodity markets and on raw materials, no qual demonstrou a sua preocupação com o suprimento de matérias-primas no mercado mundial (EUROPEAN COMMISSION, 2011). O relatório lista 14 matérias-primas, inclusive as terras raras, cuja oferta mundial é considerada crítica pela União Europeia. Em maio de 2014, a Comissão Europeia publicou outro relatório intitulado Sobre a revisão da lista de matérias-primas essenciais para a UE e a implementação da Iniciativa Matérias-Primas, que atualiza o relatório de 2011. Nesse segundo relatório, as terras raras continuam a fazer parte da lista de matérias-primas consideradas "essenciais porque os riscos de escassez do aprovisionamento e a sua repercussão na economia são maiores do que os das outras matérias-primas” (COMISSÃO EUROPEIA, 2014).

O critério utilizado pela Comissão Europeia para considerar a oferta mundial crítica depende de duas variáreis: 1) o risco de haver redução do suprimento, que leva em conta a estabilidade político-econômica do país produtor, o nível de 
concentração da produção, a possibilidade de substituição do bem e a taxa de reciclagem e reaproveitamento; e 2) a importância econômica do bem. O termo "crítico" é utilizado pela Comissão Europeia para referir-se à possibilidade (ou ocorrência) de redução da oferta de um produto, redução essa capaz de provocar danos à economia de uma nação. É um entendimento vago o suficiente para deixarse incluir nessa definição os produtos que não têm grande peso econômico, mas possuem grande importância militar. Daí por que é importante um estudo mais detalhado sobre as preocupações dos países importadores, e sobre os motivos alegados pelos que restringem as exportações, para procurar identificar até que ponto estão em jogo interesses militares e econômicos.

Ao contrário do que acontece com várias commodities que são comercializadas na bolsa de valores, em particular na London Metals Exchange, o que torna o acesso a elas mais fácil, outras matérias-primas classificadas pela União Europeia como "críticas", como é o caso das terras raras, não o são. O mercado desses materiais é menos transparente e o seu volume comercializado é bem menor. Por não ser produtora de terras raras (apesar de a Suécia possuir jazidas de terras raras), a União Europeia preocupa-se com a adoção de medidas restritivas à exportação que países exportadores desses minerais podem tomar com o intuito de privilegiar suas empresas nacionais no acesso a esse tipo de produto. Ainda de acordo com o relatório da Comissão Europeia (EUROPEAN COMMISSION, 2011), a China tem armazenado terras raras para o seu próprio consumo e, em 2006, esse país introduziu um imposto de exportação cujo efeito foi o incremento do preço das terras raras em cerca de $31 \%$. Essas medidas poderiam criar distorções e incertezas nos mercados, afetando negativamente o fluxo de compra e venda desses produtos estratégicos.

De acordo com o relatório da Comissão Europeia (EUROPEAN COMMISSION, 2011), no médio prazo, a China passará a ter a necessidade de utilizar toda a sua produção de terras raras. Aliás, a China é deficitária na produção de matériasprimas em geral, situação que tem impelido o governo chinês a buscar garantir o seu suprimento de matérias-primas noutras partes do mundo através de uma política de investimentos no estrangeiro. No que se refere especificamente à política de investimentos para garantir o acesso às terras raras, merece destaque o esforço do governo chinês de estabelecer acordos de investimentos de mineração com a Groelândia, cujo potencial produtivo de terras raras é estimado em 40\% da produção chinesa (DEGEORGES, 2012). 
Em dezembro de 2013, a Comissão Europeia organizou em Bruxelas um seminário tripartite - US-Japan-EU Trilateral Workshop on Critical Raw Materials com os Estados Unidos e com o Japão para se trocarem informações e discutirem formas de garantir o acesso a matérias-primas não energéticas, entre as quais estavam as terras raras (EUROPEAN COMMISSION, 2013).

Espera-se que em função da redução da exportação chinesa de terras raras, outros países produtores invistam na produção. Países como Estados Unidos, Canadá, Índia, Austrália e Malawi trabalham para desenvolver a produção de terras raras (EUROPEAN COMMISSION, 2010). Mas o aumento da produção se dá em longo prazo, pois em certas ocasiões pode ser necessário até 10 anos entre o início da mineração até a produção final, além de que a produção de terras raras requer investimentos de grande monta. Portanto, pressões de demanda deverão acontecer nos próximos 5 ou 7 anos sem que a oferta possa atender a esse aumento. A situação pode ser ainda mais complicada para determinados tipos de terras raras, já que a rapidez da exploração varia em função do elemento químico em questão (EUROPEAN COMMISSION, 2011).

Em resumo, as barreiras que dificultam a entrada de novos produtores de terras raras no mercado mundial são o alto custo da tecnologia usada - e que é específica para cada tipo de terra rara; o alto custo de capital (mais de 30 mil dólares por tonelada); o fato de haver poucas empresas fora da China que detêm a tecnologia para a exploração; e o fato de o mercado estar dominado pela China, que possui custos relativos mais baixos de mineração (KORINEK; KIM, 2010).

A British Geological Survey publicou o Risk List 2015, que mostra o maior risco potencial de redução da oferta, que atinge os metais e elementos maciçamente usados nas indústrias de tecnologia e cuja produção e depósitos estão concentrados em poucos países. O grau de risco é medido numa escala que vai de 1 (risco mínimo) a 10 (máximo risco). São listados 41 elementos e os elementos de terras raras lideram a lista com nota 9,5 (RISK, 2015).

Algumas organizações de pesquisa especializadas, sediadas nos Estados Unidos, também publicaram relatórios chamando a atenção do governo estadunidense para o risco de estar na dependência do fornecimento da China no que diz respeito a um recurso estratégico como as terras raras. O Congressional Research Service publicou vários relatórios sobre o tema, entre os quais destacam-se o Rare Earth Elements in National Defense: Background, Oversight Issues, and Options for Congress (GRASSO, 2011), que alerta o Congresso estadunidense sobre a vulnerabilidade da indústria militar dos EUA ao depender das exportações chinesas de terras raras; e 
o China's Rare Earth Industry and Export Regime: Economic and Trade Implications for the United States (MORRISON; TANG, 2012), que amplia essa preocupação para vários setores da indústria civil. O think tank Council on Foreign Relations publicou, em 2014, um relatório intitulado Rare Earth Elements and National Security (GHOLZ, 2014). Em 2016, o National Science and Technology Council (NSTC), órgão vinculado à presidência dos Estados Unidos, publicou o relatório Assessment of Critical Minerals: Screening Methodology and Initial Application. Nesse relatório, as terras raras aparecem catalogadas como "critical minerals", categoria que, segundo esse mesmo relatório, significa matéria-prima cuja oferta mundial é vulnerável a interrupções e cuja falta poderia causar significativas consequências de ordem econômica e de segurança (NATIONAL SCIENCE AND TECHNOLOGY COUNCIL, 2016, p. IX).

Os Estados Unidos deixaram de produzir terras raras em 2003 e assim permaneceram até 2011. Após o pico dos preços ocorrido em 2011, voltaram a produzi-las em 2012, produção essa que perdurou até 2015. A partir de 2016, deixaram de produzi-las novamente e voltaram a importar $100 \%$ das terras raras das quais precisam. Em sua maioria, provenientes da China (UNITED STATES GEOLOGICAL SURVEY, 2017).

Os principais jornais de países dependentes da exportação de terras raras provenientes da China também refletiram tal preocupação. Algumas manchetes ilustram essa situação, como, por exemplo, "Escassez de terras raras, uma bomba-relógio" (DUNKLEY, 2011); "A China irrita o mundo enquanto a batalha por terras raras amplia-se” (WHITE; ROWLEY, 2012); "Recuperar as terras raras. Para não ser reféns da China” (TAGLIACARNE, 2012); “Terras raras: China reforça controle sobre metais de alta tecnologia" (SELTENE, 2012); "Os metais raros, o ouro do tecnológico século XXI” (MEXÍA, 2013); “As terras raras são o petróleo do século XXI" (FAUJAS, 2014).

\section{Reação dos principais importadores de terras raras: o embate chega à OMC}

Os Estados Unidos, a União Europeia e o México, em conjunto, fizeram uma solicitação formal à OMC em junho de 2009 para que fosse discutida a questão da restrição à exportação de terras raras. Em março de 2012, os EUA, a União Europeia e o Japão conseguiram abrir na OMC um painel contra a China por conta das restrições à exportação de terras raras. Nesse mesmo ano, a China abrandou 
algumas restrições à exportação de terras raras, o que fez com que os preços internacionais começassem a cair.

Os demandantes do painel alegaram que a política chinesa de contenção das exportações descumpriu os artigos VII, VIII, X e XI do GATT 1994, além dos parágrafos 2(A)2, 2(C)1, 5.1, 5.2, 7.2, 8.2 e 11.3 da Parte I do Protocolo de Acesso da China à OMC, bem como das obrigações firmadas no parágrafo 1.2, Parte I do mesmo Protocolo (DS 431, 2017). Alegaram ainda que o conjunto das medidas que restringiam a exportação de terras raras tinha o objetivo de coagir a transferência de indústrias para a China, causando assim perda de empregos e de capacidade produtiva noutros países. De acordo com tal entendimento, o aumento dos preços internacionais das terras raras desvirtuou a livre concorrência, ao impor às empresas estabelecidas fora da China a compra de terras raras a preços de $20 \%$ a $40 \%$ superiores aos praticados no mercado chinês. Essas medidas foram interpretadas pelos demandantes como "subsídios artificiais” que beneficiavam as empresas chinesas.

Do outro lado, a China argumentou que sua política de restrição à exportação de terras raras não foi direcionada a nenhum país em especial e que não houve nenhuma forma de protecionismo comercial, mas que "a política foi elaborada a partir da preocupação com a preservação do ambiente, do uso e do desenvolvimento sustentável dos recursos” (ORSI, 2012). A defesa da China buscou justificativa no princípio reconhecido pela OMC de que "todo país tem o direito de regular, limitar ou proibir a exploração de seus recursos naturais com objetivos de preservação do meio ambiente” (LIMA, 2011), já que o artigo XX do Acordo Geral sobre Tarifas Aduaneiras e Comércio de 1947 garante aos países o direito de tomar medidas comerciais restritivas para preservar recursos naturais.

O painel chegou ao fim em setembro de 2014, com a derrota da China. No entendimento da OMC, a China não poderia restringir a exportação de seus recursos naturais, no caso, as terras raras, para utilizá-las para a sua indústria nacional. Os juízes do painel entenderam que a China deveria cessar as medidas de restrição à exportação e continuar a vender as terras raras aos países importadores. Foi uma decisão paradigmática porque pôs em cheque a soberania dos países membros da OMC sobre seus recursos naturais. Abriu-se, portanto, uma importante discussão no âmbito da geopolítica mundial que interliga aspectos ambientais, econômicos, políticos, estratégicos, militares, de segurança e de desenvolvimento. Aí reside a importância desse tema que tem sido discutido no âmbito da OMC (MELO; DIAS, 2015). 
A derrota chinesa no painel da OMC e o afrouxamento das restrições à exportação impostas pela China reduziram os preços após o pico em 2011, mas não se espera que caiam mais, pois a tendência mundial é de aumento do consumo de terras raras num contexto de incertezas quanto à capacidade de a oferta mundial crescer na mesma proporção da demanda mundial.

\section{A posição do Brasil no mercado mundial de terras raras}

O Brasil se apresenta como um país que reúne grandes potencialidades como produtor de elementos de terras raras. De acordo com o relatório produzido pelo Senado Federal, intitulado "Terras raras: elementos estratégicos para o Brasil" (LIMA, 2012), o início do processo de desenvolvimento industrial na área de terras raras teve sua gênese no fim na primeira metade do século XX, no estado do Rio de Janeiro, quando a monazita começou a ser manufaturada e compostos fabricados a partir dela foram desenvolvidos pela Usina Santo Amaro, localizada no município de São Francisco de Itabapoana. Até 1915, o Brasil foi o maior produtor mundial de terras raras, quando perdeu a posição para a Índia.

Até os anos de 1990, produziam-se no Brasil matérias-primas originárias de terras raras, mas como o seu custo de produção era superior ao custo de produção chinês, a produção nacional tornou-se economicamente inviável (DEUTSCHE, 2013). De um modo geral, outras empresas de capital privado surgiram e foram encerradas nos anos de 1990 em estados como São Paulo, Rio de Janeiro e Minas Gerais, algumas das quais tendo suas atividades assumidas pela Indústrias Nucleares do Brasil S.A. (INB), existente até a atualidade.

Segundo Serra (2011), o total das reservas brasileiras de terras raras é de cerca de 50 mil toneladas, mas se forem consideradas as jazidas com menores teores (aproximadamente 10\%), como as de Catalão (GO) e de Araxá (MG), esse número chega ao valor estimado de quase cinco milhões de toneladas.

A comunidade acadêmica brasileira da área de química deu início, ainda que timidamente, a discussões mais ligadas a aspectos técnicos, a respeito do que envolve a pesquisa, a exploração e a comercialização das terras raras. O Primeiro Encontro sobre Terras Raras foi organizado pela Universidade Federal de Pernambuco (UFPE), na cidade de Recife (PE), em 1994. O segundo e o terceiro encontro foram realizados, em 1995 e em 2003, pela Universidade Estadual de São Paulo (UNESP), em Araraquara (SP). Em 2010, a Universidade Federal de Sergipe (UFS) organizou o quarto encontro na cidade de Aracaju (SE). Durante aquele 
encontro, foi elaborada uma carta ao então ministro de Ciência e Tecnologia, Sérgio Machado Resende, alertando sobre a necessidade da retomada da produção de terras raras no Brasil. Naquela carta, os signatários chamavam a atenção para o fato de ser o Brasil dependente das terras raras provenientes da China e ser, ao mesmo tempo, detentor de reservas capazes de suprir a demanda nacional. Em 2012, o Quinto Encontro sobre Terras Raras foi realizado em João Pessoa (PB), organizado pela Universidade Federal da Paraíba (UFPB). Finalmente, em 2014, a comunidade acadêmica da área de química organizou o Sexto Encontro na Universidade Federal de Pernambuco (UFPE), em Recife.

O governo brasileiro criou, em 2010, através da Portaria Interministerial n ${ }^{0}$ 614/2010, o Grupo de Trabalho Interministerial do Ministério de Minas e Energia e do Ministério de Ciência e Tecnologia de Minerais Estratégicos. Esse grupo de trabalho ressaltou a importância de se discutir uma política para minerais estratégicos para o Brasil. Ainda em 2010, foi elaborado o Plano Nacional de Mineração 2030 (PNM-2030), cujo objetivo é "nortear as políticas de médio e longo prazos que possam contribuir para que o setor mineral seja um alicerce para o desenvolvimento sustentável do País nos próximos 20 anos” (BRASIL, 2010, p. XIII). Em 2011, o Ministério da Ciência, Tecnologia e Inovação, através do Centro de Tecnologia Mineral (CETEM), organizou no Rio de Janeiro o I Seminário Brasileiro de Terras Raras. Essas ações do Poder Executivo brasileiro parecem indicar que o governo começa a ter uma noção da importância econômica e geopolítica das terras raras e, de forma mais abrangente, de outros metais estratégicos, como é o caso do nióbio. Dois anos depois, em 2013, o CETEM organizou o Segundo Seminário Brasileiro de Terras Raras e, finalmente, em 2015, o CETEM organizou o Terceiro Seminário Brasileiro de Terras Raras.

A organização dos três seminários pelo governo federal, através do Ministério de Minas e Energia e do Ministério de Ciência, Tecnologia e Inovação, demonstra que há, nos órgãos públicos especializados, quadros técnicos que reconhecem a importância estratégica das terras raras, ainda que as ações sejam tímidas. Outro fato digno de se mencionar foi a publicação do edital n 76/2013 MCTI/CNPq/ CT-Mineral, cujo objetivo era fomentar o desenvolvimento tecnológico com terras raras, o que parece indicar que o Poder Executivo começa a dar os primeiros passos para elaborar uma política nacional estratégica para a produção de terras raras no Brasil.

O Serviço Geológico do Brasil (CPRM), órgão vinculado ao Ministério de Minas e Energia, deu início, em janeiro de 2013, a um projeto para mapear as 
jazidas de elementos de terras raras em solo brasileiro. O Senado Federal teve uma iniciativa importante ao criar uma subcomissão especializada sobre terras raras no âmbito das discussões do Plano Nacional de Mineração 2030. Na Comissão de Ciência e Tecnologia do Senado Federal, em 2013, houve consenso no que se refere à necessidade de o Brasil voltar a pesquisar e desenvolver a indústria de tecnologia e bens advindos de terras raras. O já falecido senador Luis Henrique da Silveira (PMDB-SC), que foi relator da subcomissão de terras raras, defendeu que o Brasil deveria priorizar o setor e que a criação de um marco regulatório para mineração de terras raras seria estratégica para a segurança nacional. O plenário do Senado aprovou, em 2014, a criação do Programa de Apoio ao Desenvolvimento Tecnológico dos Minerais de Elementos Terras-Raras (PADETR).

Em 2013, o Ministério da Ciência, Tecnologia e Inovação (MCTI) anunciou o desembolso de $\mathrm{R} \$ 11$ milhões em pesquisa e desenvolvimento com terras raras. Desse montante, R $\$ 2$ milhões foram destinados ao Centro de Tecnologia Mineral (CETEM), que desenvolve o projeto Proterraras, iniciado em 2013, e que tem por finalidade contribuir para o domínio tecnológico da produção de óxidos de terras raras e de seus usos, como uma das etapas indispensáveis para a implantação e o desenvolvimento da cadeia produtiva de terras raras no Brasil.

\section{Conclusões}

Apesar da importância estratégica que os minerais terras raras representam tanto para o desenvolvimento da indústria civil quanto militar, o tema das terras raras ainda é pouco estudado na área das relações internacionais. Possivelmente, isso se deve à relativa estabilidade da oferta mundial desses minerais até essa segunda década do século XXI. Desde os anos de 1990, quando a China assumiu a liderança mundial na produção e exportação desses metais, não havia motivos para preocupação, pois a China exportava terras raras sem restrições e a preços competitivos e atrativos. Foi justamente por essa razão que outros países, como os Estados Unidos, o Brasil e a Austrália, outrora produtores de terras raras, baseados na racionalidade econômica, pararam de extrair esses minerais e tornaram-se dependentes da exportação chinesa.

No entanto, as restrições às exportações impostas pela China, a partir de meados dos anos 2000, encerraram a fase de estabilidade no suprimento de terras raras e deram início a um período de disputa comercial entre as grandes 
potências. Os Estados Unidos, a União Europeia e o Japão levaram o assunto à OMC, na tentativa de obrigar a China a cessar a sua política de restrição às exportações de terras raras. A derrota da China no diferendo da OMC sobre as terras raras levantou questões relevantes acerca da soberania e da independência dos países membros no que diz respeito ao uso de seus recursos naturais, haja vista que a China foi condenada pela OMC, em 2014, por restringir a exportação de seu recurso natural. Enquanto o suprimento global de terras raras se mantiver em níveis compatíveis com a demanda mundial, as tensões serão amainadas, no entanto, as previsões são de que antes de 2030 a própria China tornar-se-á importadora de terras raras. Tal situação futura poderá voltar a incitar conflito em torno do acesso a esses minérios.

As terras raras são matérias-primas estratégicas para o setor industrial, cuja falta pode ocasionar problemas relacionados à segurança, inclusive militar, ao desenvolvimento das chamadas energias renováveis e, de forma mais ampla, ao desenvolvimento econômico. Algumas questões ficam como interrogações para futuras pesquisas. As políticas industriais dos membros da OMC estarão sempre limitadas às regras dessa organização internacional? Será possível resolver o choque entre a autonomia nacional e as normas da OMC? Os constrangimentos no acesso às terras raras levarão a uma fase de cooperação internacional ou de acirramento de tensões? Usará a China a sua posição de principal produtor de terras raras para tentar pressionar países dependentes das terras raras por ela exportadas?

No que se refere ao Brasil, a comunidade acadêmica parece estar mais atenta à importância das terras raras para o desenvolvimento nacional do que o governo brasileiro. Foi essa comunidade que, em 2010, reunida durante o Quarto Encontro sobre Terras Raras, alertou o governo brasileiro, em carta enviada ao Ministério de Ciência, Tecnologia e Inovação, da necessidade da retomada da produção de terras raras. O Senado Federal tomou iniciativas importantes para discutir a retomada da produção de terras raras no Brasil. As medidas tomadas pelo poder executivo são ainda incipientes quando se pensa numa estratégia de longo prazo com o fim de desenvolver a cadeia produtiva de terras raras no Brasil. A julgar pelo que foi feito até agora pelo governo federal, os tomadores de decisão ainda não têm plena consciência da importância estratégica das terras raras nem no âmbito internacional, nem no potencial que esse recurso pode representar para o desenvolvimento nacional. 


\section{Referências}

BRASIL. Ministério de Minas e Energia. Plano Nacional de Mineração 2030 (PMN-2030). Brasília: MME, 2010.

BUIJS, B.; SIEVERS, H. Critical thinking about critical minerals: Assessing risks related to resource security. Polinares EU Policy on Natural Resources. The Hague: Clingendael International Energy Programme, 2011. Disponível em: http://www.clingendaelenergy. com/inc/upload/files/Critical_thinking_critical_minerals.pdf. Acesso em: 24 abr. 2017. BUIJS, B.; SIEVERS, H.; TERCERO ESPINOZA L. Limits to the critical raw materials approach. Waste and Resource Management, 165, November 2012, p. 201-208.

CÂMARA DOS DEPUTADOS. Centro de Estudos e Debates Estratégicos. Consultoria Legislativa. Minerais estratégicos e terras raras. Brasília: Edições Câmara, 2014.

CHEN, Zhanheng. Global rare earth resources and scenarios of future rare earth industry. Journal Of Rare Earths, v. 29, n. 1, Jan. 2011, p.1-6.

WORLD TRADE ORGANIZATION. Chronological list of disputes cases. Portal Oficial da OMC. Disponível em: https://www.wto.org/english/tratop_e/dispu_e/dispu_status_e. htm. Acesso em: 25 abr. 2017.

COMISSÃO EUROPEIA. Sobre a revisão da lista de matérias-primas essenciais para a UE e a implementação da Iniciativa Matérias-Primas. Comunicação da Comissão ao Parlamento Europeu, ao Conselho, ao Comité Económico e Social Europeu e ao Comité das Regiões. COM (2014) 297 final, 26/05/2014.

DEGEORGES, Damien. Terres rares: enjeu géopolitique du XXIe siècle - Chine, États Unis, Europe, Japon, Groenland. Paris: L’Harmattan, 2012.

DEUTSCHE Welle. Alheio a riscos, Brasil quer retomar extração de terras-raras. 2013. Disponível em: http://www.dw.de/alheio-a-riscos-brasil-quer-retomarextra \% C3 \% A7 \% C3 \% A3o-de-terras-raras/a-16896952. Acesso em: 21 mar. 2016.

DS 107 Pakistan - Export Measures Affecting Hides and Skins. 1997. World Trade Organization. Portal Oficial da OMC. Disponível em: https://www.wto.org/english/ tratop_e/dispu_e/cases_e/ds107_e.htm. Acesso em: 25 abr. 2017.

DS 120 - India - Measures Affecting Export of Certain Commodities. 1998. World Trade Organization. Portal Oficial da OMC. Disponível em: https://www.wto.org/english/ tratop_e/dispu_e/cases_e/ds120_e.htm. Acesso em: 25 abr. 2017.

DS 394 - China - Measures Related to the Exportation of Various Raw Materials. 2009. World Trade Organization. Portal Oficial da OMC. Disponível em: https://www. wto.org/english/tratop_e/dispu_e/cases_e/ds394_e.htm. Acesso em: 25 abr. 2017.

DS 395 - China - Measures Related to the Exportation of Various Raw Materials. 2009. World Trade Organization. Portal Oficial da OMC. Disponível em: https://www. wto.org/english/tratop_e/dispu_e/cases_e/ds395_e.htm. Acesso em: 25 abr. 2017. 
DS 398 - China - Measures Related to the Exportation of Various Raw Materials. 2009. World Trade Organization. Portal Oficial da OMC. Disponível em: https://www. wto.org/english/tratop_e/dispu_e/cases_e/ds398_e.htm. Acesso em: 25 abr. 2017.

DS 431 - China - Measures Related to the Exportation of Rare Earths, Tungsten and Molybdenum. World Trade Organization. Portal Oficial da OMC. Disponível em: https://www.wto.org/english/tratop_e/dispu_e/cases_e/ds431_e.htm. Acesso em: 25 abr. 2017.

DS 432 - China - Measures Related to the Exportation of Rare Earths, Tungsten and Molybdenum. 2012. World Trade Organization. Portal Oficial da OMC. Disponível em: https://www.wto.org/english/tratop_e/dispu_e/cases_e/ds432_e.htm. Acesso em: 25 abr. 2017.

DS 433 - China - Measures Related to the Exportation of Rare Earths, Tungsten and Molybdenum. 2012. World Trade Organization. Portal Oficial da OMC. Disponível em: https://www.wto.org/english/tratop_e/dispu_e/cases_e/ds433_e.htm. Acesso em: 25 abr. 2017.

DS 509 - China - Duties and other Measures concerning the Exportation of Certain Raw Materials. 2016. World Trade Organization. Portal Oficial da OMC. Disponível em: https://www.wto.org/english/tratop_e/dispu_e/cases_e/ds509_e.htm. Acesso em: 25 abr. 2017.

DUNKLEY, Jamie. Rare earth metal shortage a 'ticking time-bomb'. The Telegraph, 06/12/2011. Disponível em http://www.telegraph.co.uk/finance/newsbysector/ industry/mining/8938791/Rare-earth-metal-shortage-a-ticking-time-bomb.html. Acesso em: 21 mar. 2016.

EUROPEAN COMMISSION. Critical raw materials for the EU. Report of the Ad-hoc Working Group on defining critical raw materials. Version of 30 July 2010.

EUROPEAN COMMISSION. Tackling the challenges in commodity markets and on raw materials. Communication from the Commission to the European Parliament, the Council, the European Economic and Social Committee and the Committee of the Regions. COM (2011) 25 final. Brussels, 02/02/2011.

EUROPEAN COMMISSION. US-Japan-EU trilateral workshop on Critical Raw Materials. Workshop report. Brussels, 02/12/2013.

FAUJAS, Alain. Les terres rares sont le pétrole du XXe siècle. Le Monde, 16/06/2014. Disponível em: http://www.lemonde.fr/economie/article/2014/06/16/c-est-lemoment-d-investir-dans-les-terres-rares_4438932_3234.html. Acesso em: 21 mar. 2016. GHOLZ, Eugene. Rare Earth Elements and National Security. Energy Report. New York: Council on Foreign Relations, 2014.

GRAEDEL, T. E. et al. Methodology of metal criticality determination. Environmental Science and Technology, vol. 46, n. 2, 2012, p. 1063-1070. 
GRASSO, Valerie Bailey. Rare Earth Elements in National Defense: Background, Oversight Issues, and Options for Congress. R41744. Washington: Congressional Research Service, 2011.

HATCH, G. P. Critical Rare Earths - Global supply \& demand projections and the leading contenders for new sources of supply. Technology Metals Research, Carpentersville, 2011. HUMPHRIES, Marc. Rare earth elements: the global supply chain. Report for Congress. Congressional Research Service -USA. R41347. 2012.

KIGGINS, R. D. The Strategic and Security Implications of Rare Earths. In: KIGGINS, R. D. The Political Economy of Rare Earth Elements: Rising Powers and Technological Change. International Political Economy Series. United Kingdom: Palgrave Macmillan, 2015.

KIM, Jeonghoi. Recent Trends in Export Restrictions on Raw Materials, in OECD. The Economic Impact of Export Restrictions on Raw Materials. OECD Publishing, 2010. Disponível em: http://www.keepeek.com/Digital-Asset-Management/oecd/trade/ the-economic-impact-of-export-restrictions-on-raw-materials/recent-trends-in-exportrestrictions-on-raw-materials_9789264096448-4-en\#page1. Acesso em: 21 mar. 2016. KORINEK Jane; KIM, Jeonghoi. Export restrictions on strategic raw materials and their impact on trade and global supply. Organisation for Economic Co-operation and Development. OECD Trade Policy Working Paper n. 95. 29-Mar-2010.

LIMA, Paulo Cesar Ribeiro. Terras Raras: a importância de um plano estratégico. Estudos \& Pesquisas. Caderno AsLegis. Janeiro/abril. 2011. Disponível em: http://bd.camara. leg.br/bd/handle/bdcamara/11394. Acesso em: 30 jun. 2015.

LIMA, Paulo César Ribeiro. Terras Raras: Elementos Estratégicos para o Brasil. Senado Federal, 2012. Disponível em: http://www2.camara.leg.br/a-camara/altosestudos/ arquivos/EstudoMineraisEstratgicoseTerrasRaras.pdf. Acesso em: 10 set. 2013.

MARTINS, Tereza S.; ISOLANI, Paulo Celso. Terras raras: aplicações industriais e biológicas. Química Nova, v. 28, n. 1, 2005, p. 111-117

MAYER, Herbert; GLEICH, Benedikt. Measuring Criticality of Raw Materials: An Empirical Approach Assessing the Supply Risk Dimension of Commodity Criticality. Natural Resources, vol.6, 2015, p.56-78. Disponível em: http://www.scirp.org/journal/nr http://dx.doi.org/10.4236/nr.2015.61007. Acesso em: 24 abr. 2017.

MELO, Filipe Reis; DIAS, Hamana Karlla Gomes. A disputa por recursos estratégicos militares chega à OMC. Boletim Meridiano 47, v.16, n.151, 2015, p.37-45.

MEXÍA, Fernando. Los metales raros, el oro del tecnológico siglo XXI. El País, 17/01/2013. Disponível em: http://economia.elpais.com/economia/2013/01/17/ agencias/1358419709_572518.html. Acesso em: 21 mar. 2016.

MORRISON, Wayne M.; TANG, Rachel. China's Rare Earth Industry and Export Regime: Economic and Trade Implications for the United States. R42510. Washington: Congressional Research Service, 2012. 
NASSAR, N. T. et al. Criti- cality of the geological copper family. Environmental Science and Technology, vol. 46, n. 2, 2012, p. 1071-1078.

NATIONAL SCIENCE AND TECHNOLOGY COUNCIL. Committee on Environment, Natural Resources, and Sustainability Subcommittee on Critical and Strategic Mineral Supply Chains. Assessment of Critical Minerals: Screening Methodology and Initial Application. Washington: Executive Office of The President, March 2016.

ORSI, Carlos. Senado discute marco regulatório para exploração de terras raras. 2012. Disponível em: http:// www.tnsustentavel.com.br/noticia/8717/Senado + discute + m arco + regulatório + para + explorac são + de + terr as + raras. Acesso em: 12 dez. 2013.

UNITED STATES GEOLOGICAL SURVEY. Rare Earths Statistics and Information. Mineral Commodity Summaries, January 2017. Annual Publications. Disponível em: https:// minerals.usgs.gov/minerals/pubs/commodity/rare_earths/. Acesso em: 25 abr. 2017.

RISK List 2015. Minerals UK. 2015. Disponível em: http://www.bgs.ac.uk/mineralsuk/ statistics/risklist.html. Acesso em: 21 mar. 2016.

SELTENE, Erden. China verstärkt Kontrolle über Hightech-Metalle. Spiegel on Line, 09/04/2012. Disponível em: http://www.spiegel.de/wirtschaft/unternehmen/chinagruendet-wirtschaftsverband-fuer-seltene-erden-a-826373.html. Acesso em: 21 mar. 2016.

SERRA, Osvaldo Antonio. Terras raras: Brasil x China. Journal of the Brazilian Chemical Society, v.22, n.5, São Paulo, May 2011. Disponível em: http://www.scielo.br/scielo. php? script $=$ sci_arttext\&pid $=$ S0103-50532011000500001\&lng $=$ en\&nrm $=$ iso\&tlng $=$ pt. Acesso em: 12 dez. 2013.

SOUSA FILHO Paulo C. de; SERRA, Osvaldo A. Terras Raras no Brasil: histórico, produção e perspectivas. Química Nova, v. 37, n. 4, 2014, p.753-760.

TABELA periódica completa. Tabelaperiodicacompleta.com. 2017. Disponível em: https://www.tabelaperiodicacompleta.com/lantanideos/. Acesso em : 18 set. 2017.

TAGLIACARNE, Anna. Recuperare le Terre rare. Per non essere ostaggi della Cina. Corriere della Sera, 12/06/2012. Disponível em: http://www.corriere.it/scienze/12_giugno_12/ terrerare-riciclo-ostaggio-cina_b278c63e-b3e3-11e1-a52e-4174479f1ca9.shtml. Acesso em: 21 mar. 2016.

WEBER, David. Terres Rares: avenir industriel et future richesse de l'Europe? Puteaux: Les Éditions du Net, 2012.

WHITE, Garry; ROWLEY, Emma. China angers the world as battle for rare earth metals escalates. The Telegraph, 18/03/2012. Disponível em: http://www.telegraph.co.uk/ finance/commodities/9151608/China-angers-the-world-as-battle-for-rare-earth-metalsescalates.html. Acesso em: 21 mar. 2016.

ZHANG, S. Problems and Countermeasures of Rare Earth Industry in China. Canadian Social Science. Vol. 9, n .3, p. 9-14, 2013. Disponível em: http://www.cscanada.net/index. php/css/article/view/j.css.1923669720130903.Z1013/4250. Acesso em: 26 abr. 2017. 


\section{Instruções editoriais para os autores}

Os autores devem seguir estritamente as diretrizes abaixo; sua não observância poderá implicar em não aceitação do artigo submetido, sendo os autores orientados a adequar o arquivo submetido aos padrões requeridos.

1. O artigo deve ser inédito e redigido em português ou em inglês. Além de inédito, o artigo não deve estar em apreciação concomitante em nenhum outro periódico ou veículo de publicação, no todo ou em parte, no idioma original ou traduzido.

2. O arquivo a ser enviado deve estar em formato.doc ou.docx; use somente a formatação padrão do texto. Os autores devem retirar sua identificação das propriedades do arquivo.

3. Não serão aceitos artigos com mais de 4 (quatro) autores/co-autores. No caso de mais de dois autores, a equipe editorial se reserva o direito de solicitar informações sobre o papel de cada um dos autores no processo de desenvolvimento do artigo.

4. O autor deve submeter três arquivos:

4.1 Um arquivo contendo título, resumos, palavras chave, corpo do texto e referências. No texto do artigo, o responsável pela submissão deve eliminar qualquer referência que possa permitir sua identificação.

4.1.1 No caso de um trabalho fruto de pesquisa financiada, o autor deve abrir uma nota de rodapé na primeira página do artigo para se referir ao financiamento e às agências de fomento que o possibilitaram.

4.2 Um arquivo, a ser submetido como suplementar, contendo a identificação dos autores, sua titulação máxima e a instituição a qual se encontra atualmente filiado, um resumo do Curriculum vitae de, no máximo, 5 linhas, contendo titulação, função que desempenha na instituição à qual é filiado e a URL do Currículo Lattes. Em casos de artigos com múltiplos autores, a informação de todos os autores deve ser apresentada. Neste mesmo arquivo, o autor poderá incluir agradecimentos, se desejar.

4.3 Uma Carta ao Editor, que deve ser enviada também como arquivo suplementar, na qual assume que o conteúdo do trabalho apresentado é inédito, não contém nada que possa ser considerado ilegal, difamatório, que cause conflito de interesses ou que possa interferir na imparcialidade do trabalho apresentado.

5. O arquivo com o corpo do texto não deve conter nenhuma forma de identificação dos autores; a formatação do texto deve estar em espaço simples; fonte de 12-pontos; uso do itálico em vez de sublinhado (exceto em endereços URL); as figuras e tabelas devem ser inseridas no texto, e não no final do documento na forma de anexos. 
6. O artigo deve conter o mínimo de 7.000 e o máximo de 8.000 palavras, incluídos título, resumo e palavras chave (em português e em inglês), corpo do texto e notas de rodapé; excluídas as referências.

6.1 Serão adotadas no máximo cinco palavras-chave em cada idioma. Elas devem se referir ao objeto de estudo do artigo e ao referencial teórico e/ou temática utilizada para análise.

7. O artigo deve incluir um resumo em português e em inglês, entre 150 a 200 palavras para cada uma das versões. Lembramos que o resumo em ambos os idiomas integra o número mínimo e o máximo de palavras, conforme indicado no item 6.

8. As notas de rodapé devem se restringir a esclarecimentos adicionais ao texto. Todas as referências de fonte bibliográfica ou outras deverão ser feitas no corpo do texto, conforme o sistema de citação Chicago (AUTOR, data).

8.1 As citações devem estar no mesmo idioma que o artigo. Assim, será acrescentada no corpo do texto a versão traduzida, e em nota de rodapé, a versão original da citação.

9. A formatação de tabelas, quadros e figuras deverá seguir o formato ABNT.

10. As referências devem ser listadas ao final do texto e devem se restringir àquelas efetivamente citadas no artigo. Deve ser observado estritamente o sistema Chicago (AUTOR, data). Não serão aceitas referências bibliográficas em notas de rodapé.

As mesmas deverão seguir os modelos abaixo, de acordo com o formato estabelecido pela NBR 6023 (2002) da ABNT.

10.1 Para artigos ou documentos eletrônicos:

Elementos: AUTOR(es). Título. Título da publicação. Local de publicação, numeração correspondente ao volume, número, mês e ano de publicação, paginação inicial e final. Indicar o endereço (link) onde o documento está disponível e a data de acesso ao artigo.

MIYAMOTO, Shiguenoli. Política Externa Brasileira: 1964-1985. Carta Internacional, v. 8, n. 2, 2013, p. 3-19. Disponível em: http://www.cartainternacional. abri.org.br/index.php/Carta/article/view/120/64. Acesso em: 14 jul. 2016.

10.2 Para Livros

Elementos: AUTORES(es). Título. Edição (a partir da $2^{a}$ edição). Cidade: Editora, ano de publicação.

SARAIVA, José Flávio S. Foreign Policy and Political Regime. Brasília, DF: IBRI, 2003. 
10.3 Para capítulos de livros:

Elementos: AUTOR(es) do capítulo. Título do capítulo. In: AUTOR(es) da obra (Org., Ed., Coord.) Título da obra. Edição (a partir da $2^{\text {a }}$ edição). Cidade: Editora, ano de publicação. Capítulo consultado e paginação da parte.

SNIDAL, Duncan. The politics scope: endogenous actors, heterogeneity and institutions. In KEOHANE, Robert O; OSTROM, Elinor. Local commons and global interdependence: heterogeneity and cooperation in two domains. London: Sage Publication, 1995. Cap. 2, p. 47-70.

10.4 Trabalhos apresentados em Eventos

Elementos: AUTOR(es). Título do trabalho apresentado. In: nome do evento, numeração do evento (se houver), ano e local (cidade) de realização, título do documento (anais, atas, tópico temático), local, editora, data de publicação e página inicial e final da parte referenciada.

VENTURA, Deisy de Freitas Lima; PEREZ, Fernanda Aguilar. A política externa de saúde de Dilma Rousseff (2011-2014): elementos preliminares para um balanço. In: $5^{\circ}$ Encontro Nacional da ABRI, 2015, Belo Horizonte. Anais Eletrônicos. Disponível em: < http://www.encontronacional2015. abri.org.br/site/anaiscomplementares?AREA $=14 \% 2017>$. Acesso em: 14 jul. 2016.

11. No ato da submissão, todas as informações requeridas no sistema deverão ser devidamente preenchidas.

\section{Condições para submissão}

Como parte do processo de submissão, os autores são obrigados a verificar a conformidade da submissão em relação a todos os itens listados a seguir. As submissões que não estiverem de acordo com as normas serão devolvidas aos autores.

1. A contribuição é original, inédita e não está sendo avaliada para publicação por outra revista. Caso contrário, deve-se justificar em "Comentários ao editor".

2. O arquivo da submissão está em formato Microsoft Word, OpenOffice ou RTF.

3. URLs para as referências foram informadas quando possível.

4. O texto está em espaço simples; usa uma fonte de 12-pontos; emprega itálico em vez de sublinhado (exceto em endereços URL); as figuras e tabelas estão inseridas no texto, não no final do documento na forma de anexos.

5. O texto segue os padrões de estilo e requisitos bibliográficos descritos em Diretrizes para Autores, na página Sobre a Revista.

6. Em caso de submissão a uma seção com avaliação pelos pares (ex.: artigos), as instruções disponíveis em Assegurando a avaliação pelos pares cega foram seguidas. 

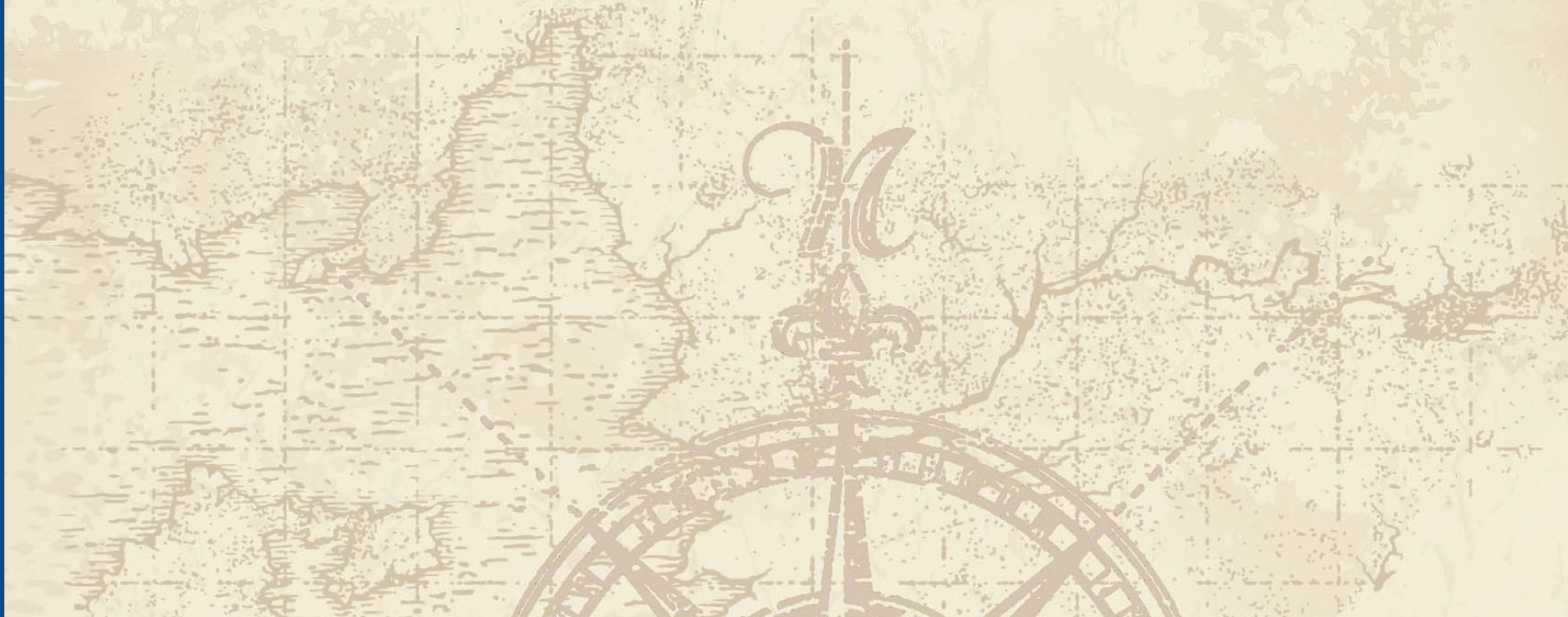

for

$=0-(x)$

$=3$
-0.4
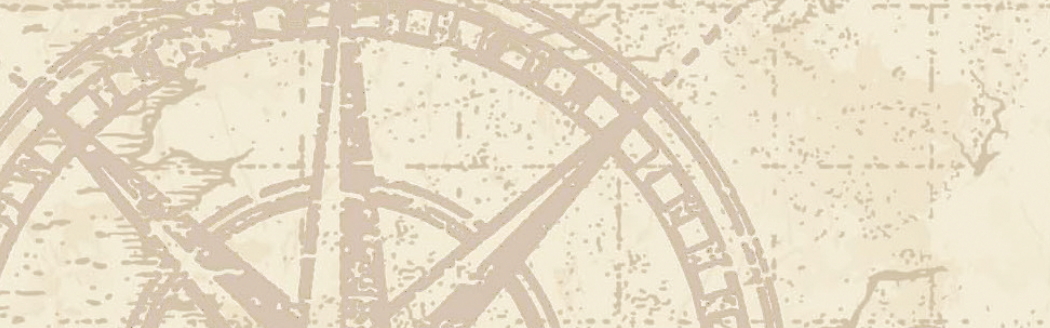